UNIVERSIDADE DE SÃO PAULO

FACULDADE DE FILOSOFIA, LETRAS E CIÊNCIAS HUMANAS

DEPARTAMENTO DE FILOSOFIA

PROGRAMA DE PÓS-GRADUAÇÃO EM FILOSOFIA

\title{
A TRAMA DA TERRA QUE TREME: MULTIPLICIDADE EM HÉLIO OITICICA
}

PAULA PRISCILA BRAGA

Tese de doutorado apresentada ao Programa de PósGraduação em Filosofia da Faculdade de Filosofia, Letras e Ciências Humanas da Universidade de São Paulo

Orientador: Prof. Dr. Celso Fernando Favaretto

São Paulo

2007 


\section{RESUMO}

As estratégias construtivistas na obra de Hélio Oiticica estão compreendidas na noção definida pelo artista de "mundo erigindo mundo". Esta estratégia é identificável tanto nos aspectos éticos e estéticos das proposições de Oiticica quanto na maneira como seu próprio pensamento é construído de blocos achados nas obras de filósofos, músicos e outros artistas.

Este trabalho percorre manuscritos de Hélio Oiticica disponíveis em arquivos digitais para identificar os blocos de pensamento que embasam a produção de Hélio Oiticica, identificando a singularidade de sua obra frente a propostas de alguns de seus contemporâneos.

Ainda que reconhecendo a importância do mito e da Mangueira na obra do inventor da Tropicália, o texto enfatiza que a "síntese" feita por Hélio Oiticica não se deixa fixar em um estereótipo cultural já que escapa dos espaços delimitados e do tempo cronológico, estabelecendo-se em um "mundo-abrigo" virtual, onde Oiticica acha fragmentos das produções de inventores de vários lugares e épocas para compor seu programa além-da-arte.

Palavras-chaves: Construtivismo; Experimental; Nietzsche; Eterno Retorno; Arte Brasileira. 


\begin{abstract}
The constructivist strategies within Hélio Oiticica's oeuvre are comprehended in the notion of "world building world" articulated by the artist. This strategy is discernible both on the ethic and aesthetic aspects of Oiticica's proposals and on the way his own thought is built out of blocks he found in works by philosophers, musicians and other artists.

This text traverses manuscripts by Hélio Oiticica, available in digital archives, to identify the building blocks of the artist's thought and its singularity in relation to proposals of some of his contemporaries.

Although recognizing the importance of the myth and of the Mangueira samba school on the work of the inventor of Tropicalia, this text emphasizes that the "synthesis" produced by Hélio Oiticica defies cultural stereotypes since it escapes boundaries and the chronological time, establishing itself within a "world-shelter" where the artist finds fragments of the production of other inventors from different cultures and times, to compose his own beyond-the-art program.
\end{abstract}

Keywords: Constructivism; Experimental; Nietzsche; Eternal Return; Brazilian Art. 
Para Roberto Braga, que adorava as escolas de samba. 


\section{AGRADECIMENTOS}

A orientação que recebi de Celso Favaretto foi imprescindível para a escrita desse texto. Além de precioso impulso acadêmico, contei com seu apoio em períodos difíceis e palavras certas nas horas certas. Sou profundamente grata a meu orientador.

Minha pesquisa foi imensamente facilitada pelos arquivos digitalizados de manuscritos de Hélio Oiticica. Agradeço às pessoas e instituições envolvidas na especificação e manutenção do Programa $\mathrm{HO}$ e Arquivo $\mathrm{HO}$ e em especial ao Projeto $\mathrm{HO}$ por me ceder o arquivo digital e fotografias que uso nesse trabalho.

Durante mais de um ano, tive também em mãos o arquivo pessoal de documentos e anotações de Beatriz Scigliano Carneiro sobre Hélio Oiticica, que além desse empréstimo, presenteou-me com idéias e muito de seu tempo durante minha pesquisa. Muito obrigada.

Nesse labirinto de informações, duas bússolas estiveram sempre comigo: Fabio, que sempre me motiva em direção a coisas novas, e Alan, inspiração e alegria, que conviveu quase sua vida toda com "a tese" e aprendeu a falar Oiticica muito cedo. 


\section{ÍNDICE}

1. Prelúdio

2. Mundo erigindo Mundo $\quad$............................................................. 13

3. Conceitualismo e Vivência $\quad$................................................................ 104

4. Do Barracão ao Mundo-Abrigo ….................................................... 158

5. Conclusão

6. Bibliografia 
1

1

I TRANA DA TERRA QUE TREMS

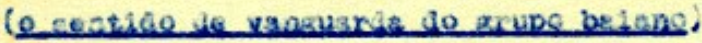

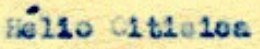

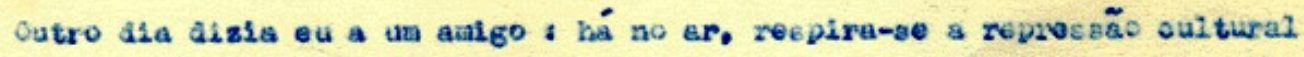

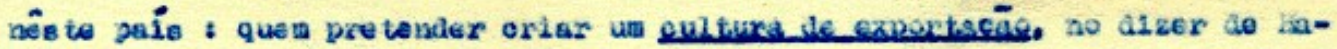

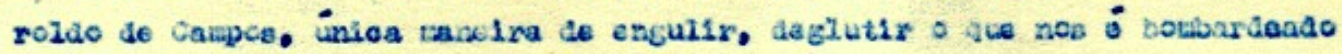

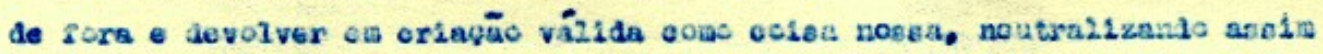

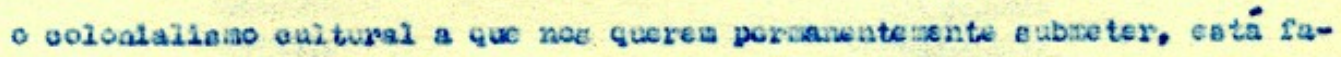

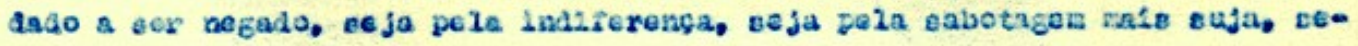
ga pule reapäo violenta, veetida es ta de lireita, a la corção, ou de certo

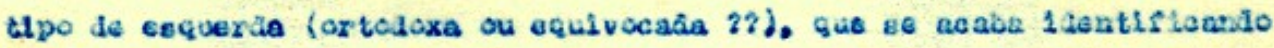

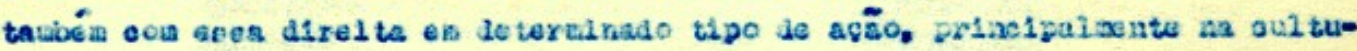
ral. veriflquel is to beu olaro dursatz of debeter pwomeriasg reesntodoate no

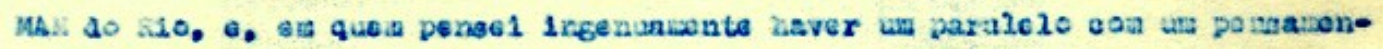
to a que chanars 1 denranguarda não o havla. Perque i se guares, ou dizez

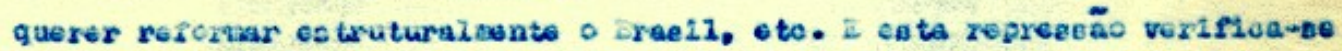

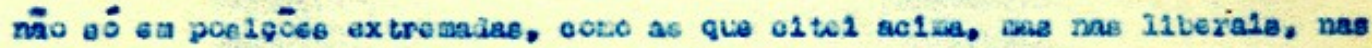

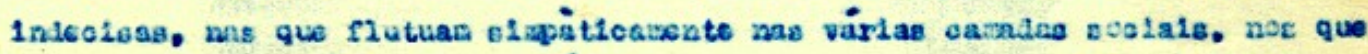

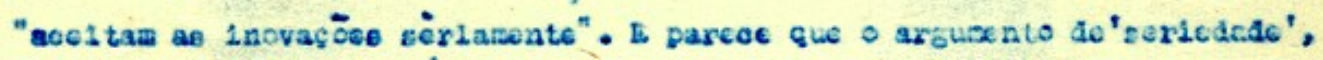

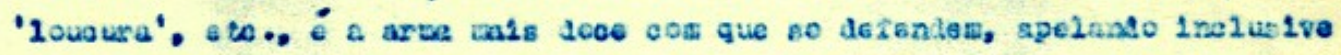

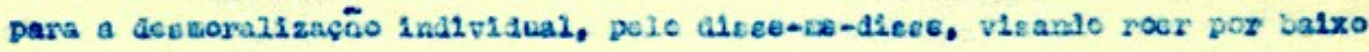

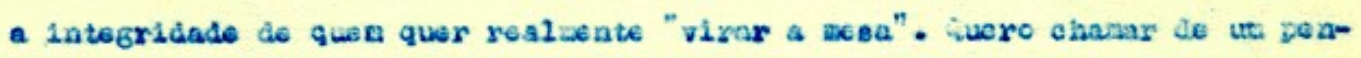

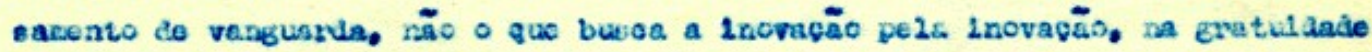

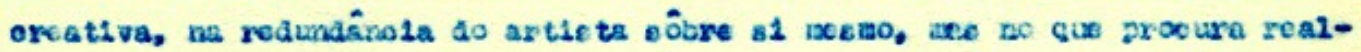

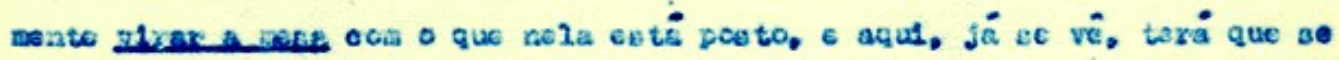

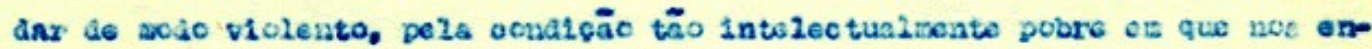

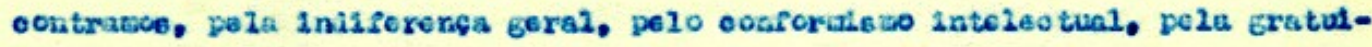

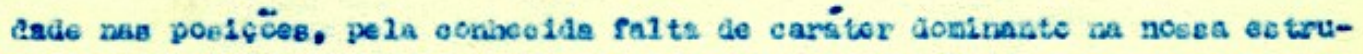

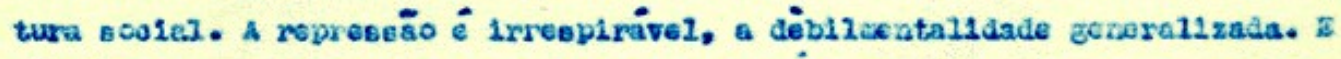

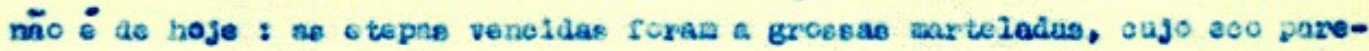

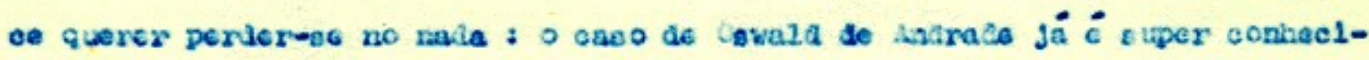

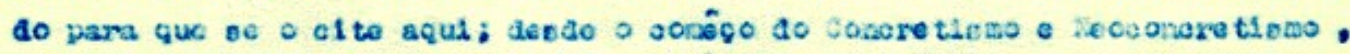
tôase as teatativas realisonto renovadorae as eestido total pareceir sofrer a mesan reprseeąo generallzada : une pulaa fora, outros subceterae a tôas aepéole de sabotage in, de ladiferenga por aqui : walo tande o que fol folto 'antes' ¿ Invocado somo una quallade perila contra o quo é proposto no mosento, e 


\section{Prelúdio: o labirinto virtual}

HO é a charada que quem almeja atravessar o rio-de-fogo e chegar do outro lado, na outra margem, vai ter que enfrentar (...) não é uma viagem através do nosso passado, é a viagem através do nosso futuro.

Waly Salomão, Qual é o Parangolé, p. 117

Assim, para mim, quando realizo maquetas ou projetos de maquetas, labirintos por excelência, quero que a estrutura arquitetônica recrie e incorpore o espaço real num espaço virtual, estético, e num tempo, que é também estético.

HO, 22 de fevereiro de 1961 


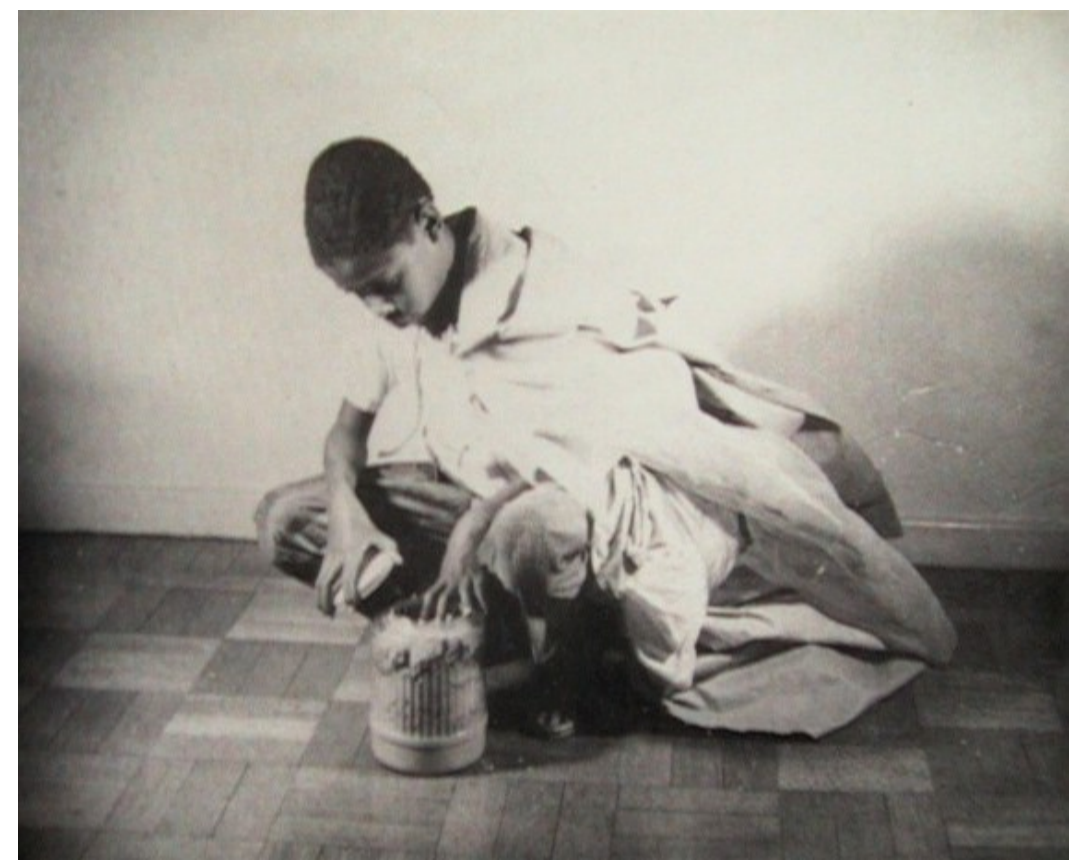

Mosquito da Mangueira vestindo Parangolé P4 capa 1 (1964) e abrindo o Bólide plástico 1

(1966). Foto: Hélio Oiticica

Se o tempo na obra de Hélio Oiticica admitisse algum tipo de ampulheta, escoaria nas mãos de quem revolve pó colorido contido em uma cuba de vidro. Tudo está na cuba, existindo na simultaneidade.

Tudo está relacionado com o passado e não está, é claro, inclusive o presente e o futuro; mas, e se lhe disser que não sinto essa relação entre passado-presente-futuro? Então tudo se borra e desaparece, porque quando se vive o crelazer, isso não existe; a grande descoberta do mundo atual seria o viver em absoluto, sem a relação velha de tempo cronológico, que é repressiva e cruel. $^{1}$

${ }^{1}$ OITICICA, Hélio. “A Criação Plástica em Questão: Respostas”. Manuscrito disponível no Arquivo HO (AHO 0159.68) e no Programa HO (PHO 0159.68) publicado em AYALA, Walmir (org). A Criação Plástica em questão. Petrópolis: Vozes, 1970. p. 163-166.

Usamos dois arquivos digitais com fac-símiles dos manuscritos de Hélio Oiticica. Cada arquivo possui características próprias e complementares quanto a ferramentas de busca e velocidade de acesso aos documentos e assim foram utilizados simultaneamente durante essa pesquisa. A numeração dos manuscritos é a mesma nos dois arquivos digitalizados, com raras exceções. O "Arquivo HO" foi desenvolvido pelo Projeto $\mathrm{HO}$ e inclui também fotografias e artigos sobre Hélio Oiticica escritos por vários críticos e pesquisadores, publicados em jornais e revistas. São cerca de 8.000 documentos distribuídos a pesquisadores pelo Projeto $\mathrm{HO}$ em $4 \mathrm{Cds}$ e um programa de gerenciamento de banco de dados para busca por palavras-chaves. Daqui por diante, iremos nos referir a esse arquivo por AHO, seguido do número do documento. 
Os escritos de Oiticica permitem o afrouxar da linearidade cronológica. Abandonando a linha de tempo, escolhe-se livremente um ritmo e um fio condutor da leitura. Além das entrevistas concedidas a revistas de sua época e textos preparados para publicação, Hélio Oiticica preencheu vários cadernos, colocando em palavras seus pensamentos sobre cada proposição. São os notebooks, que o artista carregava consigo e nos quais fazia anotações, por vezes retrabalhadas em textos datilografados e traduzidos para outro idioma ${ }^{2}$. Uma pequena parte de seus textos não publicados em vida está reproduzida em catálogos de exposições e uma maior parcela veio recentemente a público em bancos de dados virtuais que oferecem fac-símiles do material do arquivo de Hélio Oiticica.

Navegando por um enorme arquivo virtual, o leitor encontra caderninhos de bolso, folhas avulsas, fotografias, peças de teatro escritas na juventude e outros blocos de pensamento a serem percorridos sem uma marcação fixa, que propiciam leituras múltiplas e associações determinadas pelo acaso, por um tempo distinto para cada estudioso de sua obra. Organizar a obra e a leitura segundo o tempo cronológico e linear é possível, pois Oiticica datava seus escritos, mas é uma perda de tempo. O fio da cronologia impede que o leitor se perca no grande labirinto.

O passeio pelo labirinto é outro se for marcado por um cordão de fios trançados. Os fios enroscam-se nas várias referências citadas em um manuscrito, o cordão desfia e

O pesquisador da obra de Hélio Oiticica conta também com um arquivo online com cerca de 5.000 fac-símiles dos manuscritos, com comentários sobre cada documento, resultado de uma parceria entre o Projeto HO e o Instituto Itaú Cultural, desenvolvido sob coordenação de Lisette Lagnado e intitulado "Programa HO"( http://www.itaucultural.org.br/aplicexternas/enciclopedia/ho/). Daqui por diante, iremos nos referir a esse arquivo online por PHO seguido do número do documento.

Constam desses arquivos digitais dois "notebooks de 1973", cadernos de anotações com páginas numeradas que eram referenciados como "ntbk1/73" (AHO e PHO 316.73) e "ntbk2/73" (AHO e PHO 189.73 ) pelo próprio artista em outros escritos. Mantivemos essa abreviação ao citar esses dois cadernos de 1973, seguida do número da página do caderno.

${ }^{2}$ Oiticica escrevia em inglês e em português, e elaborava versões em ambas as línguas para alguns de seus textos. É comum também encontrar, em seus escritos, citações em francês de livros que Oiticica estava lendo (Artaud, Deleuze, Sartre, por exemplo). Não há, no entanto, textos totalmente escritos por Oiticica em outro idioma exceto inglês e português. Dos textos publicados em vida, muitos estão em jornais e revistas como O Pasquim, Presença e GAM e na coluna de Torquato Neto, "Geléia Geral", do jornal Última Hora. 
transforma-se em vários fios soltos: um que leva a Nietzsche, outro que leva a Caetano Veloso, outro ainda para Jimi Hendrix, Cage, Mangueira, Mondrian, etc., até perdermos a possibilidade de achar um só caminho de volta.

Este trabalho investiga a obra de Hélio Oiticica a partir da constatação de que há em Oiticica uma multiplicidade de artistas. Hélio costura com vários fios uma constelação formada por muitos pontos luminosos. A partir de um chão de inventores (ou céu de referências), Oiticica ergue seu programa ambiental. A invenção, palavra recorrente nos textos do artista, é exatamente essa mistura de outras invenções. Ou seja, lidamos aqui com uma constatação trivial: há inúmeras referências a outros teóricos e artistas conduzindo a produção e auto-crítica de arte feita por Oiticica. No entanto, nos textos de Oiticica essas referências são mais do que afinidades, e constituem parte fundamental do programa in progress: uma simultaneidade de inventores construindo o artista que chamamos de Hélio. No decorrer deste texto alguns desses pontos luminosos aparecerão com mais nitidez, clarificando a estratégia de Oiticica de se apoiar em outras obras para articular seus próprios vislumbres. É com euforia que Oiticica cita Nietzsche, Maliévitch, Bergson, Cage, entre outros, ao perceber nos trabalhos desses inventores passagens que confirmam e expandem suas idéias como a valorização do corpo, o suprasensorial ou o experimental.

Muitos outros artistas revelam suas referências e afinidades teóricas. A singularidade de Oiticica é usar essas referências como esquema construtor não só de conceitos mas também de proposições. A noção de "mundo erigindo mundo", como argumentaremos, é tradução em forma de bloco, matéria concreta, da diáfana expressão "galáxia de inventores". "Mundo erigindo mundo" está presente nos fragmentos que formam bólides, na dança do parangolé, no Barracão e na obra escrita Newyorkaises.

Optamos por investigar a multiplicidade de artistas que coexistem em Hélio Oiticica analisando textos pouco estudados do conjunto de manuscritos, com ênfase nos escritos da década de 1970. É justamente nos anos 1970 que a "galáxia de inventores" torna-se mais recorrente nos manuscritos de Oiticica. São "inventores" os artistas capazes de levar adiante a busca por uma arte que detone a vitalidade criativa dos 
participadores, transformando a arte em veículo de descondicionamento e expansão do comportamento criativo, aqui entendido como uma existência criadora.

O que procuro, e devemos todos procurar, deverá ser o estímulo vital para que este indivíduo seja levado a um pensamento (aqui comportamento) criador - o seu ato, subjetivo, o seu instante puro que quero fazer com que atinja, que seja um instante criador, livre (...): propor ao indivíduo que este crie suas vivências, que consiga ele liberar seus contrários, seus temores e anseios reprimidos. O psicanalista faz algo semelhante com seu paciente, mas sua proposição é exclusiva ao paciente que o procura. Para o artista propositor o paciente não é aquele mas sim o mundo das individualidades ou seja, o homem. $^{3}$

Com Newyorkaises, obra-texto da década de 1970 que retoma proposições da década anterior, Oiticica cria um ambiente de convívio de inventores de várias épocas, mapeando uma galáxia de pontos luminosos que deixam traços em todos seus textos: não uma coleção de "gênios" esparsos, mas uma trama de singularidades que se intensificam e coexistem num tempo estético.

O tempo, em Hélio Oiticica, é estético: corre em simultaneidades de atos, movimentos e obras que combinam o que já existe em uma coisa nova, que por sua vez é um novo instante de tempo e assim garante a "contiguação"4 da vida.

${ }^{3}$ OITICICA, Hélio.”À Busca do Suprasensorial”, 10/10/1967. PHO 192/67.

${ }^{4}$ Expressão de Hélio Oiticica. cf. OITICICA, Hélio. ntbk 2/73 p. 92. 


\title{
2. Mundo erigindo Mundo
}

\author{
CONTIGUAÇÃO (...) Inventar: processo in \\ progress q não se resume na edificação de OBRA \\ mas no lançamento de mundos q se simultaneiam. \\ Simultaneidade em vez de mediação.
}

HO, $23 / 10 / 1973^{5}$

\begin{abstract}
Para avançar com a realidade movente, é nela que seria preciso reinserir-se. Instalem-se na mudança, vocês aprenderão ao mesmo tempo a mudança ela própria e os estados sucessivos nos quais ela poderia a todo instante imobilizar-se (...) toda tentativa de reconstituir a mudança com estados implica essa proposição absurda de que o movimento é feito de imobilidades.

Henri Bergson ${ }^{6}$
\end{abstract}

\footnotetext{
${ }^{5}$ OITICICA, Hélio. ntbk 2/73, p. 92.

${ }^{6}$ BERGSON, Henri. A Evolução Criadora. Bento Prado Neto (trad.). São Paulo: Martins Fontes, 2005, p. 333.
} 


\subsection{Insert-takes}

Em Nova Iorque, ao conceber um texto que condensasse seus pensamentos, Oiticica projetou Newyorkaises, uma coleção de "fragmentos-blocos": "estou reformulando muitas idéias, retomando outras e montando um texto-montagem só de excertos de outros artistas, escritores, ensaístas, etc."7 Oiticica refere-se a Newyorkaises pelo título de Conglomerado na entrevista a Gardênia Garcia "O Artista da Terceira Margem", de 1978, e diz que pretendia publicá-lo pela editora Pedra que Ronca, de Waly Salomão ${ }^{8}$.

Suas próprias anotações, registradas nos notebooks ao longo das décadas de 60 e 70 integram Newyorkaises também como fragmentos. Assim, encontramos nos rascunhos de Newyorkaises junções como a planejada no seguinte trecho do rascunho para o bloco Cosmococa. "NTBK" são referências a seus notebooks, dos quais Oiticica retiraria fragmentos, como faria também com Rimbaud, Cage e outros.

Titles: as in NTBK 2/73 p. 51

RIMBAUD: Illuminations

Veillées

(just estrophe no. 1)

* JOHN CAGE; SILENCE P. 133

(xerox from original for exact format)

All things nothing

*( SEE: NTNK 2/73 p. 85)

\footnotetext{
${ }^{7}$ CLARK, Lygia e OITICICA, Hélio. Lygia Clark - Hélio Oiticica: Cartas, 1964-74. Luciano Figueiredo (org.). Rio de Janeiro: UFRJ, 1998, p. 219 (carta de 24/01/1972).

${ }^{8}$ Entrevista a Gardênia GARCIA, "O Artista da Terceira Margem". Arte Hoje, ano 2, no. 16, Rio de Janeiro, outubro de 1978.
} 


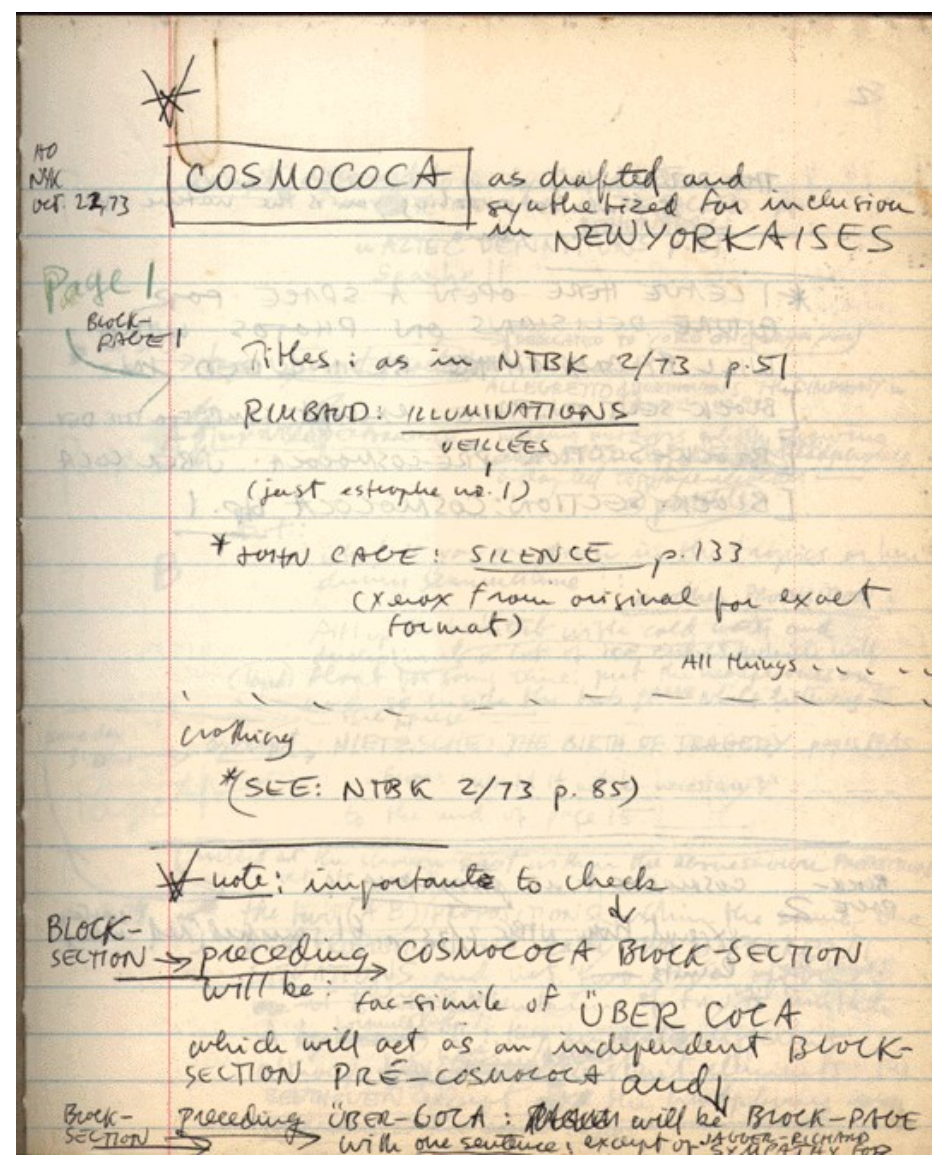

Página com rascunho para bloco Cosmococa de Newyorkaises. PHO 0311/73

É intrigante que a maior parte desses rascunhos de Newyorkaises, repletos de lacunas, referências a páginas de livros e notebooks, não tenham sido retrabalhados em uma versão final. Muitos textos avulsos escritos por Oiticica ao longo de sua vida passaram por várias versões, datilografadas, corrigidas, e traduzidas para outro idioma pelo próprio Oiticica. Os rascunhos para Newyorkaises, ao contrário, têm a velocidade de vislumbres, de lembranças, de um fluxo de pensamento que não pode ser interrompido, nem mesmo para a transcrição completa do trecho de uma obra citada. Em carta para Lygia Clark, Hélio dá indícios de como seria esse livro:

Sua carta foi muito importante para definir e esclarecer uma série de coisas e principalmente para que eu acrescente na seção de corpo (BODYWISE) do livro que faço a importante e claríssima definição sua (como sempre) e que peço aqui sua permissão para usar coisas da carta. Penso em colocar num espaço grande em cor ou branco o seguinte:

LYGIA CLARK: 
É a fantasmática do corpo, aliás, o que me interessa, e não o corpo em si.

Essa citação seria em cor que vibre sobre o fundo como luz (complementares)(...)

Lygia, lhe digo uma coisa, um segredo: tudo o que em um ano acumulei de revelação e de escrita para essa publicação, sinto assim como algo que na maior parte nunca foi ventilado nos mundos de artes/ filosofias/ etc., e ao mesmo tempo existe mas não se conhece; sinto-me como sentado em dinamite, por isso expressar algo seu certo e eficazmente é mais do que importante; é um modo de fazer a coisa conhecida e mostrar (para quem tiver olhos e cabeça) que esses argumentos são não só os mais importantes como os únicos importantes e a expressão mais alta do que se propõe, como tudo o mais e principalmente na merdice da crítica de arte e teorias vazias daqui $(. . .)^{9}$.

Os rascunhos para Newyorkaises realmente parecem a escrita de alguém que está "sentado em dinamite", sem tempo para dar vazão a todos os pensamentos, mas há outros textos da época de concepção de Newyorkaises, que vai mais ou menos de 1972 a 1975, retrabalhados e datilografados, tais como "Experimentar o Experimental"10, de 1972 e “Cosmococa- Programa in Progress"11, de 1974.

A escrita sempre acompanhou Hélio Oiticica e após a exposição em Londres, na Whitechapel Gallery, em 1969, torna-se, ao lado do filme, lugar de refúgio, abrigo cercado pelas paredes maleáveis dos $\operatorname{Ninhos}^{12}$ de Nova Iorque:

Realmente nada tenho a fazer aqui [Londres]; sinto-me morrendo aos poucos. Em Sussex foi bom, contruí células para a experiência Barracão; os estudantes fantásticos, e cooperaram à beça; acho que me satisfiz mais do que a experiência, além disso o período lá foi dos mais criativos; comecei a escrever coisas que chamo de contos numa linguagem inventada, e os autos, que seriam uma autobiografia inventada também, isto é, nada de narrações ou textos factuais, etc. Penso em publicar os contos lá para o fim do ano, no Brasil, e creio que possa fazer tutu com isso. Tenho lido muito e tenho plano completo para um filme e uma "peça", que não sei quando começarei a fazer, apesar de simples. No Brasil não quero aparecer nem fazer coisas públicas, pois seria uma compactuação com o regime; além disso, se eu não ficar quieto, prendem-me; se a bolsa

\footnotetext{
${ }^{9}$ CLARK, Lygia e OITICICA, Hélio. Lygia Clark - Hélio Oiticica: Cartas, 1964-74. op. cit. p. 225-229 (carta de 11/07/74)

${ }^{10}$ OITICICA, Hélio. "Experimentar o Experimental", 1972. PHO 0380/72, datilografado, traduzido para o inglês em caderno manuscrito conforme documento em PHO 0511/72. A primeira página dessa tradução diz : "Translation from Portuguese ho nyk mar 22, 72 Experimentar o Experimental/ translated: jan 1, 1973"

${ }^{11}$ OITICICA, Hélio. "Cosmococa- Programa in Progress". PHO 0301/74

${ }^{12}$ Nos dois apartamentos em que morou em Nova Iorque, Oiticica construiu uma estrutura que chamava de ninhos: divisões feitas de tecido transparente, delimitando espaços para cada morador ou visitante do apartamento, como grandes beliches suavemente separados e unidos por transparências.
} 
Guggenheim sair, melhor, mas só conto com o que tenho em mãos e jamais com utopias. Iria então para New York, por algum tempo, pois é o único lugar, fora o Rio, onde posso respirar (...) (...) Quanto a produções minhas, levaria mais tempo para conseguir fazer o que quero. Filme seria mais imediato. Portanto, como vê, filme, conto, "peça" e tudo o mais, além da experiência comunal, é tudo parte de uma ambição maior, mais universal e mais difícil; encerrei minha época de fundar coisas, para entrar nessa bem mais complexa de expandir energias, como uma forma de conhecimento 'além da arte'; expansão vital, sem preconceito ou sem querer 'fazer história' etc. ${ }^{13}$

Um exemplo notável da ênfase no texto e no filme que marca a estadia de Oiticica em Nova Iorque é Cosmococas - Program in progress, nome de um bloco de Newyorkaises e de uma proposta. Uma "parte experimental" dessa proposta é formada pelos Block-Experiments $\mathrm{CC} 1$ a CC9, que começaram a ser concretamente realizados em locais públicos 30 anos depois de sua concepção. Circularam em forma de texto, no entanto, ao longo de três décadas.

Parte e todo misturam-se em Newyorkaises, mundo construído com outros mundos, mas é importante enfatizar a diferença entre o nome da proposta (Cosmococas Program in Progress) e o título de uma de suas instanciações (Block-Experiments) para o completo entendimento de textos do período de Oiticica em Nova Iorque.

emphasis on it being program in progress - open program in an effort to show that COSMOCOCA is meant to embrace a much wider spectrum of experiments and as such should not be identified exclusively with these BLOCK-EXPERIMENTS (abbreviated CC followed by the corresponding number): they are the first experimental part of COSMOCOCA - program in progress (...) these BLOCK-EXPERIMENTS are really a kind of quasi-cinema: a structural innovation within NEVILLE's work and an unexpected field for my longing to INVENT in the light of my dissatisfaction with "cinema-language". ${ }^{14}$

\footnotetext{
${ }_{13}$ A relevância desse trecho de uma carta de Oiticica a Lygia Clark datada de 23/12/1969 foi enfatizada por Lisette Lagnado. cf. LAGNADO, Zizette Dwek. O Mapa do Programa Ambiental. Tese de doutorado, Faculdade de Filosofia, Ciências e Letras da Universidade de São Paulo, 2003. p. 198.

${ }^{14}$ OITICICA, Hélio. "Block-Experiments in Cosmococas - Program in Progress, 1973" em Hélio Oiticica: Quasi-Cinemas. Carlos BASUALDO (org). Kölnischer Kunstverein, New Museum of Contemporary Art, Wexner Center for the Arts, The Ohio State University, 2001. "ênfase em ser Programa in progress programa aberto num esforço de mostrar que COSMOCOCA foi feita para abarcar um espectro muito maior de experiências e assim não deve ser identificada exclusivamente com esses BLOCKEXPERIMENTS (abreviados CC seguidos do número correspondente): eles são a primeira parte experimental de COSMOCOCA - program in progress (...) esses BLOCK-EXPERIMENTS são realmente um tipo de quasi-cinema: uma inovação estrutural no trabalho de Neville e um campo inesperado para minha nostalgia de INVENTAR à luz de minha insatisfação com a 'linguagem cinematográfica'"(trad. da autora)
} 
Uma boa definição do que seria Cosmococa - Program in Progress aparece em um texto de Oiticica que comenta um filme de Alfred Hitchcock, Under Capricorn, de 1949. Apesar da sua "insatisfação com a linguagem cinematográfica", Oiticica usa as cenas iniciais desse filme como estrutura aberta que possibilita uma "conseqüência"15: a articulação teórica de Cosmococa - Program in Progress. O filme de Hitchcock inspirou em Oiticica uma "explanação do que seja Cosmococa program in progress", experimento de pensamento criativo maior do que os Block-Experiments:

vendo agora o início de um filme de HITCHCOCK (considerado "menor" dele) UNDER CAPRICORN (1949) pensei em algo q talvez seja a melhor explanação para o q seja COSMOCOCA program in progress: nesse início de UNDER CAPRICORN HITCHCOCK coloca insert-takes de mapas-vivos enquanto conta sucintamente a história da descoberta da AUSTRÁLIA (...) ${ }^{16}$

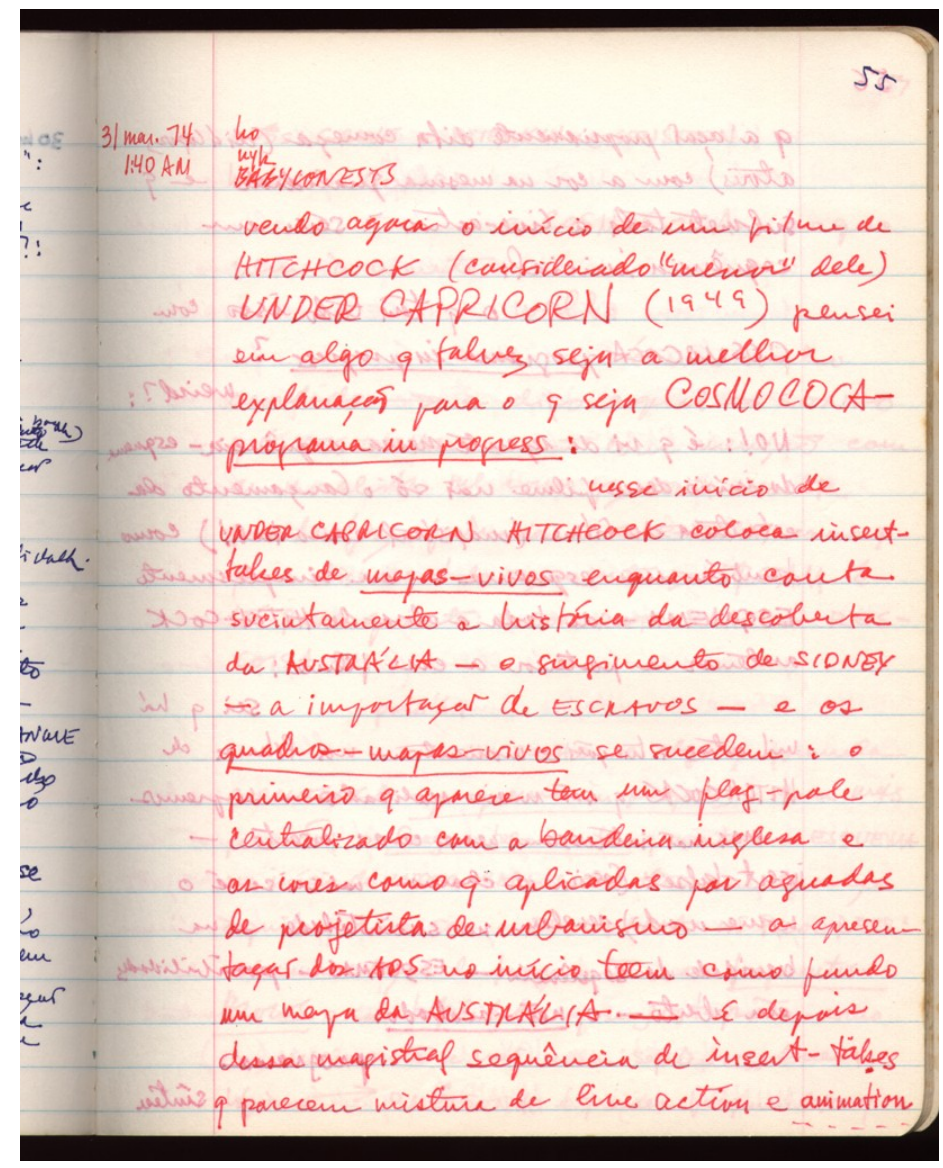

Manuscrito de 31/03/74 sobre o filme "Under Capricorn” de Hitchcock

\footnotetext{
${ }^{15}$ Como veremos mais adiante, a "conseqüência" para Oiticica é uma evolução não-linear.

${ }^{16}$ OITICICA, Hélio. "Vendo um filme de Hitchcock, 'Under Capricorn'”, 31/03/1974 PHO 0318/74 $15 / 24$.
} 

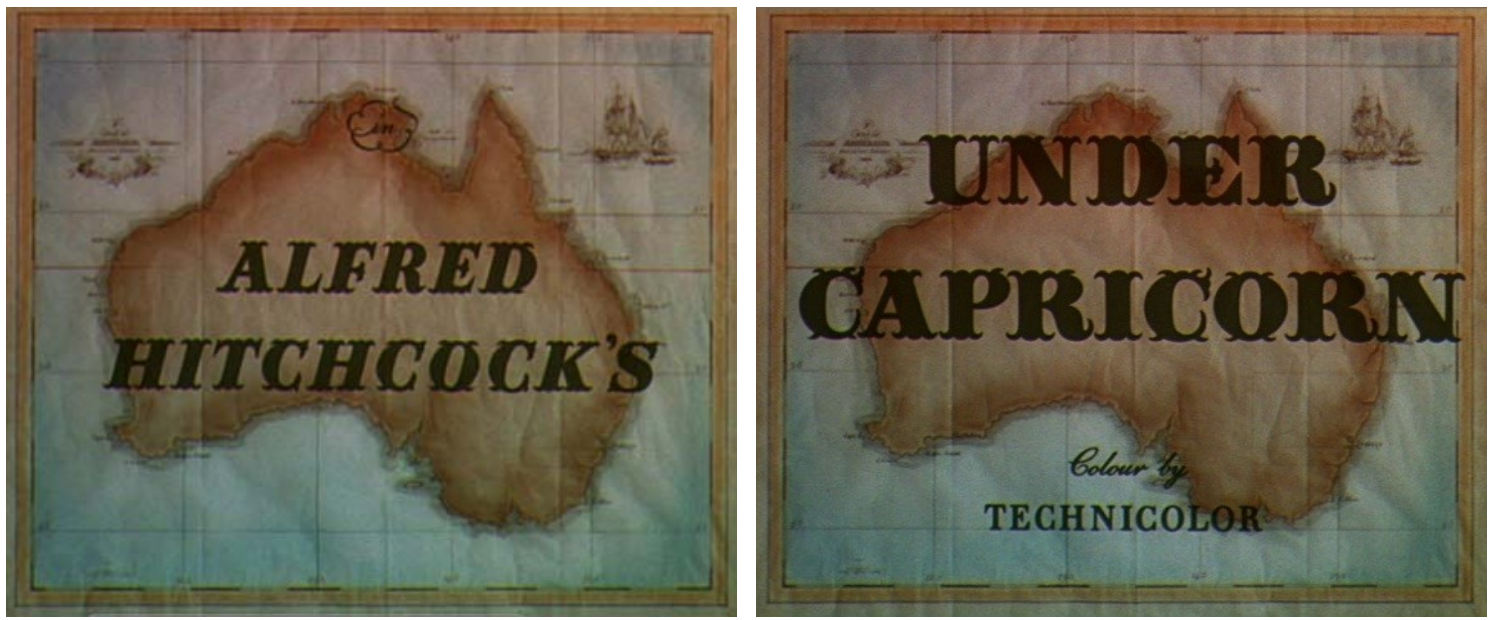

A seqüência de "insert-takes" nesse filme de Hitchcock dura pouco mais de 30 segundos. Under Capricorn passa-se em Sidney, no início da colonização da Austrália pela Inglaterra. O filme começa com a imagem de um mapa da Austrália, sobre o qual foi sobreposta uma grade de leves riscos feitos a lápis. A próxima camada de sobreposições exibe, por cima do mapa, os créditos do filme, nomes dos atores, diretor, etc. Após os créditos inicia-se a breve seqüência de 30 segundos que Oiticica nomeou de "mapasvivos", em contraposição ao mapa estático até então exibido. Os mapas-vivos são cenas aéreas da cidade de Sidney. De algum ponto do céu, a câmera mostra a cidade de parcas construções em 1770, numa tomada que enfatiza os movimentos de uma grande bandeira do colonizador. O narrador apressa-se para terminar a frase sobre o descobrimento daquelas terras pelo Capitão Cook, antes que a próxima cena substitua a primeira. A segunda cena ainda exibe uma vista aérea da cidade 60 anos depois, com altos andaimes de construção em primeiro plano que desviam o olhar do espectador para o céu. A terceira cena continua a ser aérea, e vê-se uma vila já com várias casas e um porto. Um céu branco é o fundo da quarta cena, que mostra o desembarque, no porto, de prisioneiros de mãos atadas que, por terem um passado de delitos, eram compulsoriamente enviados a 
Sidney como trabalhadores, construtores de uma nova nação. Finalmente, na quinta cena, novamente aérea, Sidney, em 1831, é uma cidade pulsante e a ação do filme começa.

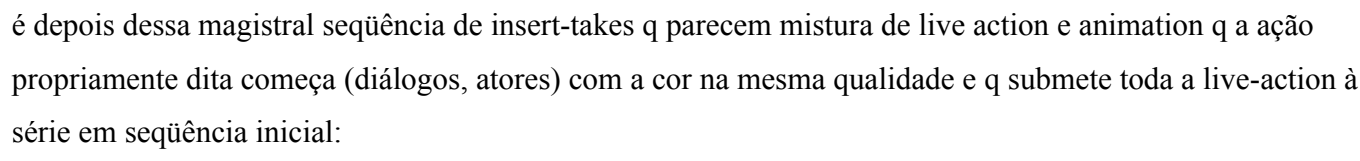

No! É q vi de repente nessa seqüência-esquema do início do filme não só o lançamento da estrutura do filme (magistral como tal!) como também um esquema - ou simplesmente ESQUEMA - de toda a obra de HITCHCOCK anterior e posterior a esse filme (...) insert-takes (assim os chamo, não sei se é o nome usado) revelam na sucintidade - na brevidade da seqüência - ESQUEMAS - possibilidades em aberto - o não acabado:

programa síntese

avôs: GREVE e POTEMKIN: EISENSTEIN

herdeiro: GODARD

Para Oiticica, as breves cenas de abertura do filme determinavam a estrutura de uma obra aberta: construção a partir de inúmeras referências e "andaimes". Além disso, os fragmentos no início de Under Capricorn sugerem à Oiticica a idéia da obra aberta como uma herança que Hitchcock recebeu de Eisenstein e repassou a Godard e ao próprio Oiticica, num esquema análogo ao conteúdo histórico desses "insert-takes" sobre o desenvolvimento de Sidney: eterna construção.

Ao conceberem os Block-experiments in Cosmococa (abreviados $\mathrm{CC}$ ), entre março de 1973 e março de 1974, Hélio Oiticica e Neville D’Almeida indicaram alguns dos inventores que consideravam como blocos construtores do que estavam inventando: CC1 com Buñuel, Luis Fernando Guimarães e Frank Zappa, CC2 com Yoko Ono, CC3 com Marilyn Monroe, CC4 com John Cage, CC5 com Jimi Hendrix.

os fragmentos-inserts q montam o ESQUEMA no início de UNDER CAPRICORN têm semelhança àquilo que deva ser o PROGRAMA IN PROGRESS: não uma coleção de fragmentos mas fragmentos-blocos q são totalidades q se justapõem como em crescimento e não uma seqüência linear lógica $\rightarrow$ o MEU SONHO é q esses fragmentos q no filme se referem a HITCHCOCK indivíduo-criador total em COSMOCOCA vá incorporando descontinuamente e ao mesmo tempo vá alimentando o q chamaria de CAMPO 
EXPERIMENTAL no q defino como EXPERIMENTALIDADE BRASILEIRA: a existência de tal campo é real e forte (...) nas minhas iniciativas de apropriação/ absorção/ togethernassão de fragmentos q se estruturam em blocos e proposições procuro a não-limitação em grupo homogêneo ou de casta: dirijo-me ao que me vem de encontro na cabeça: o q é aberto e não contente com o "feito": um JOY de descobrir (-se) MUNDO erigindo MUNDO (...) mas MEU SONHO é q COSMOCOCA a cada fragmento se modifica e acaba por formar como q uma GALÁXIA de INVENÇÃO de manifestações individuais poderosas: LUZ q intensifica: mais luz ${ }^{17}$

A rápida mudança de slides dos Block-experiments in Cosmococas ao som da trilha sonora de cada CC pode ser comparada aos insert-takes de Hitchcock, que são momentos, fragmentos de tempo, que Hitchcock selecionou para criar a introdução à narrativa que se segue no filme. Por mais propositalmente veloz que seja a narrativa que acompanha a rápida sucessão de insert-takes, o espectador sabe que houve um grande lapso de tempo entre uma cena e outra. Em 30 segundos cria-se a ilusão de passagem de 60 anos na história da construção de Sidney. O restante do filme, em 24 quadros por segundo, cria a ilusão de "live-action". Mas a "ação-viva" não é sucessão descontínua de estados congelados, por mais rápida que seja a seqüência de quadros que cria a ilusão cinematográfica. Ação-viva acontece naqueles que estão assistindo o filme. É o espectador quem possui duração real e tempo fluido como uma de suas dimensões de existência. Os block-experiments in Cosmococas intensificam o congelamento da imagem e a atribuição de movimento ao espectador-participador.

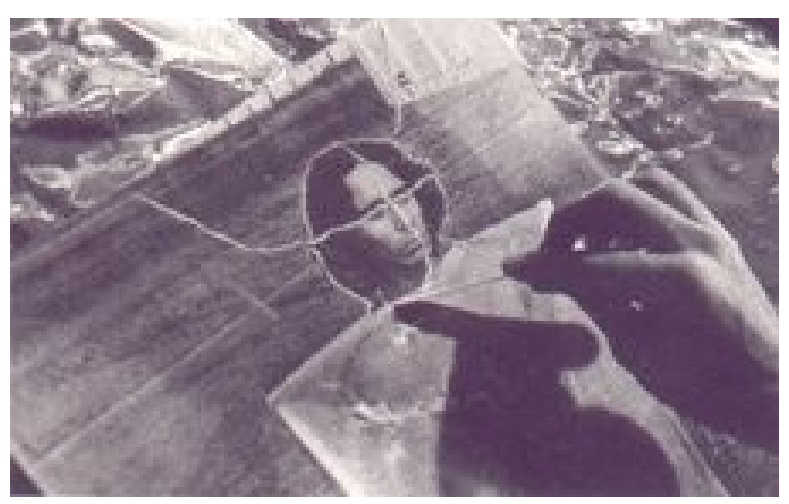

Hélio Oiticica e Neville D'Almeida, Block-Experiments in Cosmococa - Programa in Progress - CC1 Trashiscapes

${ }^{17}$ OITICICA, Hélio. "Vendo um filme de Hitchcock, 'Under Capricorn'”, op.cit. 
Na seqüência de slides dos Block-experiments, o suporte para as trilhas de coca está imóvel. A mão que desenha as trilhas brancas é dotada de movimento no momento de "fazer o rastro" mas aparece imóvel nos slides, tão congelada em um estado quanto as fotografias de Marilyn Monroe ou Yoko Ono. O que a projeção de slides cria não é "algo" dotado de duração mas apenas um "momento-algo"18, uma "parada virtual."19 O que possui real duração nos Block-experiments in Cosmococas é o participador que está sempre em movimento, seja lixando unhas, seja balançando em redes ou nadando numa piscina.

- fragmentação do cinetismo: a mão q faz rastrococa-maquilagem move-se gilete/lâmina/faca ou o q seja sobre imagem-flat-acabada: filme-se ou fotografe-se: não importa: --> o cinetismo do "fazer o rastro" e sua "duração" no tempo resultam fragmentadas em posições estáticas sucessivas como momentos-frames one-by-one q não resultam em algo mas já constituem momentos-algo em processo-MAQUILAR

MANCOQUILAGEM $^{20}$

Ao optarem pelo uso de slides e não pelo filme, Oiticica e D'Almeida desnudam essa "fragmentação do cinetismo", optando por uma experiência de cinema feito de imagens que são marcos discretos e não uma seqüência cuja intenção seja criar a ilusão de continuidade com sucessão rápida de imagens.

$\mathrm{Na}$ discussão sobre cinetismo, Henri Bergson, filósofo usualmente associado às experiências de Oiticica com a cor no final da década de 1950 e início dos anos 1960, reaparece no pensamento de Oiticica dos anos 1970 como numa curva da fita de Möebius. Em A Evolução Criadora, Bergson dedica um capítulo ao "mecanismo cinematográfico do pensamento e a ilusão mecanicista." O cinematógrafo cria uma ilusão de movimento ao justapor imagens estáticas rapidamente. No entanto, o que a máquina faz é conferir um "movimento em geral" (o movimento da máquina) àquilo que foi

${ }^{18}$ OITICICA, Hélio, “Cosmococa by Neville D'Almeida”, 24/junho/1973. OITICICA, Hélio. ntbk 2/73, p. 51

${ }^{19}$ BERGSON, op. cit,.p. 338

${ }^{20}$ OITICICA, Hélio, "Cosmococa by Neville D'Almeida", 24/junho/1973 (OITICICA, Hélio. ntbk 2/73, p. 51). Reproduzido em Cosmococa Program in Progress. Projeto Hélio Oiticica, Fundación Eduardo F. Constantini, Centro de Arte Contemporânea Inhotim, catálogo da exposição realizada em 2005 no MALBA - Buenos Aires, p.62- 63. 
fotografado. Perde-se o movimento interior, a duração própria do objeto fotografado. Nosso conhecimento funciona de maneira semelhante ao cinematógrafo: "Percepção, intelecção, linguagem geralmente procedem assim. Quer se trate de pensar o devir, quer de exprimi-lo, quer mesmo de percebê-lo, não fazemos realmente nada além de acionar uma espécie de cinematógrafo interior." ${ }^{21}$ Pensamos o movente através de imagens imóveis.

Pode-se ler Newyorkaises orientado pela idéia das "posições estáticas sucessivas". Existe uma continuidade de invenções, porém apresentada em "momentos", instantes de criação que Oiticica copia para seu livro enciclopédico. A criação artística é movente. Ao grafá-la, tenta-se criar a ilusão de movimento e continuidade. Newyorkaises explicita o mecanismo cinematográfico do pensamento e exibe, como em slides, blocos que constroem a arte que Oiticica almeja. O verdadeiro movimento que restituirá "liveaction" a esses blocos está no leitor e nas conseqüências que cada um dará a Newyorkaises. Luz que intensifica: mais luz.

\footnotetext{
${ }^{21}$ BERGSON, op. cit., p. 331.
} 
ExiTS. 1

excess. 2 is

diametrally

shincingune prese Title for fRT

NEWYORKAISES French NEWYORCASES

wall St. Reid for aye $B$.

NEWKOSMAISES

NEYKOSMOSIS

NEYKOSMAISES mixed Eng. French

NEWYORKIANA mixed Eng. Pret.

NOVORQUIANA Pint ert.

NEWYORQUIANA mixed Eng.-Pont.

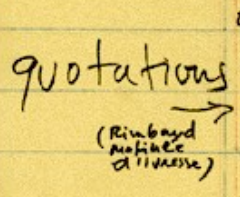

opening loose on white paged

nous anons foil au poison

escochar de TOR Q UATO: From a lyric only 2 first lines $\downarrow$

I was dreaming of a steel/ guitar engagement When you drunk my health in scented jasmine tea Yeah, you knifed me in my filthy dinky basement with that jaded, faded junky nurse

$u \rightarrow$ And there will always be a space in my parking lot when you weed a little coke and sympattany.

Don'chat think there's a place tor you in between the sheets?

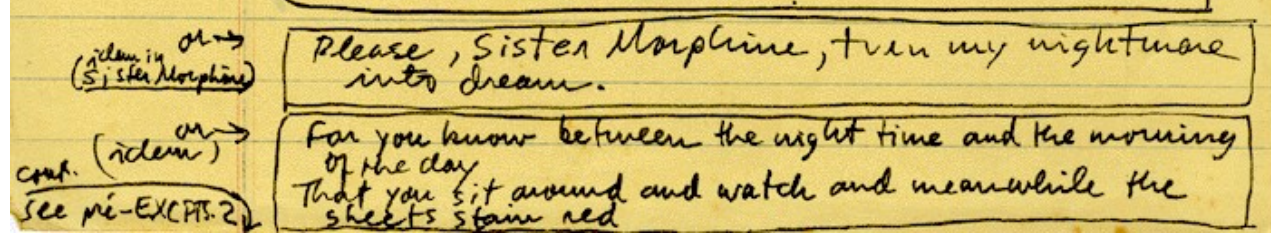

Manuscrito preparatório para Newyorkaises, PHO 242/73

24 


\subsection{Ezra Pound: lâminas e inventores}

Para chegar à articulação do estado de invenção, Oiticica recorre a conceitos de diversos autores tais como o branco no branco de Maliévitch, o artista trágico Nietzschiano, ou as "classes de pessoas" que criam literatura segundo Ezra Pound no livro $A B C$ da Literatura $^{22}$. Nesse manual sobre como discernir boa poesia da má poesia, publicado originalmente em inglês em 1934, Pound defende a seletividade de referências e o uso de alguns autores específicos como baliza para avaliação de outras obras. A comparação de um poema com algumas produções exemplares revelaria seu valor como literatura. Conforme explicado por Augusto de Campos, esse "método de laboratório" consiste em colecionar algumas "lâminas" ou "espécimes" às quais outros materiais seriam comparados, método que se contrapõe a tentativas de definição teórica e em termos conceituais daquilo que é boa literatura.

Oiticica leu obras de Ezra Pound ${ }^{23}$ e sua amizade com os irmãos Campos provavelmente reforçou seu contato com obras como o $A B C$ da Literatura, traduzido para português por Augusto de Campos e José Paulo Paes. Uma das frases que Pound escreve nesse livro, "News that stays News"24, é usada por Oiticica para explicar o que é a invenção no texto "Homage to my Father", de 1972.

POUND: Literature is news that STAYS news.

nada novo-consumo mas invenção inventar news é novo não novo-consumo

(...) news não-consumo é news-POUND q STAYS news tudo creation-invenção inventor

scraps pro alto CACIQUES 'crapeiam scraps da rua pro alto oferenda-samba

RAMOS-CENTRAL bloco-sambar scraps-roupa puzzlescrapeizados scrap-vestir

rebutalho plástico-indústria roupa-BONZÃO no suor tirar jogar scrapalto

\footnotetext{
${ }^{22}$ POUND, Ezra. ABC da Literatura. Augusto de Campos e José Paulo Paes (trad.). São Paulo: Cultrix, 1970. A presença de Pound na articulação da invenção já foi apontada por CARNEIRO, Beatriz Scigliano. Relâmpagos com Claror: Lygia Clark e Hélio Oiticica, vida como arte. S. Paulo: Imaginário, 2004.

${ }^{23}$ Em carta para Lygia Clark de 24/01/1972, Hélio diz: "O Haroldo de Campos vem em março com a Guggenheim; vai ser legal, pois estamos grandes amigos: ele é realmente inteligentíssimo; Augusto idem; estou lendo a beça as coisas que eles enviam, fora outras; vou aprender grego e chinês, que sei, são essenciais para se ler poesia, etc., e aproveitar que moro pertinho da New York University onde tem cursos, e baratos, dessas línguas; claro que é para ler, e não falar (grego clássico); quero ler Homero e Sapho, Confúcio; meu inglês está perfeito agora e estou ficando feito a Mary: horas a ler Joyce, minha grande paixão; Pound também; adorei o livro dos Campos, Panorama do Finnegans Wake." CLARK, Lygia e OITICICA, Hélio. Lygia Clark - Hélio Oiticica: Cartas. op. Cit., p. 219. Homero, Safo e Confúcio são exemplos de boa literatura selecionados por Pound no $A B C$ da Literatura.

${ }^{24}$ POUND, op. Cit., p. 33: "Literatura é novidade que permanece novidade"
} 
news novo no news absoluto news newsance ${ }^{25}$ newsinventado new

scrapnew news no-scraprevival

scrap ritmoembandeirado altojogado ${ }^{26}$

Essa "homenagem ao pai" nos leva a especular sobre o quanto o método de laboratório de Pound teria impressionado o filho do fotógrafo e entomologista José Oiticica Filho. O pai de Hélio chegou à fotografia justamente para aperfeiçoar seus estudos científicos sobre borboletas e outros insetos, pesquisa que desenvolvia como parte da equipe do Museu Nacional do Rio de Janeiro na época de seu falecimento, em $1964^{27}$. O manual de Pound sugere um mergulho científico no mundo de certos "espécimes". No lugar de definições abstratas, o laboratório, a comparação concreta, exame direto: qual a distância entre a poesia em exame e os "espécimes" selecionados por Pound (que incluem literatura chinesa, e no ocidente, nomes que vão de Safo a Rimbaud)?

Temos aqui outra pista para a compreensão de Newyorkaises: a obra escrita de Oiticica que revela seu método de invenção ao juntar fragmentos de outros autores também possui esse caráter laboratorial, de junção de lâminas exemplares, lâminas conglomeradas. Ao mesmo tempo em que se sustenta como obra, Newyorkaises estabelece o laboratório para identificar a invenção através das citações de fragmentos de obras de outros artistas. Dichten (poesia) = condensar, diz Pound" ${ }^{28}$."Separação drástica do melhor" nas palavras de Augusto de Campos. Oiticica, depois de separar o que mais interessa, condensa. No "Conglomerado" as partes não estão separadas, mas reunidas num todo coerente. Condensação aqui é condensação da matéria e não liqüefação de um vapor; é o mundo aglutinado em um ponto, pronto para explodir e formar outros mundos.

A parte do manual de Pound que precede a apresentação das "lâminas" é muito breve. Pound expõe em poucas linhas sua classificação de inventores, mestres, diluidores,

\footnotetext{
${ }^{25}$ Aqui a palavra "newsance" reúne new (novo), naissance (nascimento), nonsense (sem sentido), nuisance (perigo), numa bela síntese que sugere o nascimento do novo a partir do acaso e de fragmentos (scraps) lançados para o alto, como um jogo de dados. Oiticica refere-se nesse trecho ao bloco CACIQUE de RAMOS, um assunto que exploramos mais adiante nesse capítulo.

${ }^{26}$ OITICICA, Hélio. "Homage to my Father", 08/03/1972. AHO 451.72

${ }^{27}$ cf. CARNEIRO, Beatriz Scigliano, op. cit., p. 178

${ }^{28}$ POUND, op. Cit,.p. 40.
} 
bons escritores, belles letres e lançadores de moda. Oiticica apega-se em especial à categoria do "inventor" ( "homens que descobriram um novo processo, ou cuja obra nos dá o primeiro exemplo conhecido de um processo") e do "diluidor" ("homens que vieram depois das duas primeiras espécies de escritor [inventores e mestres] e não foram capazes de realizar tão bem o trabalho”). Mas radicaliza-as: só interessa o inventor. O artista só pode inventar. Invenção é "o que não pode ser diluído."

Penetráveis, Núcleus, Bólides, Parangolés, foram o caminho para a descoberta do que eu chamo de estado de invenção, acho que daí é impossível haver diluição, não se trata nada de ficar nas idéias... não existe idéia separada do objeto, nunca existiu, muito menos nesse caso; o que existe é a invenção... não há mais possibilidade de existir estilos, ou a possibilidade de existir uma forma de expressão unilateral como seja a pintura, a escultura departamentalizada... só existe o grande mundo da invenção... (...) $\mathrm{O}$ artista só pode ser inventor, senão ele não é artista. $\mathrm{O}$ artista tem que conduzir o participador ao que eu chamo de estado de invenção (...) o artista só pode ser concebido como tal se ele chegar ao grande estado de invenção, uma situação que não se trata mais de puras invençõeszinhas aqui, invenção de detalhes. É a grande invenção. A grande invenção, ela é imune a diluição. Daí se tornar também superada a distinção entre mestres, diluidores e inventores; só interessa o que é inventor: o resto existe mas não interessa mais como fenômeno do processo artístico e criador (...) ${ }^{29}$

A publicação do $A B C$ da Literatura de Pound em tradução para o português de Augusto de Campos e José Paulo Paes é de 1970. Vale notar que o texto "Brasil Diarréia", no qual Oiticica fala da "diluição" como estagnadora do potencial criativo na arte brasileira, também é de $1970^{30}$ e que a palavra "inventor" no sentido Poundiano passa a ser recorrente nos escritos de Oiticica somente após essa data. Antes disso, Oiticica

\footnotetext{
${ }^{29}$ OITICICA, Hélio. Áudio da entrevista a Ivan Cardoso transcrito com imprecisões em LUCCHETTI, R. F. Ivampirismo : o cinema em pânico. Rio de Janeiro: Editora Brasil-América, Fundação do Cinema Brasileiro, 1990, p. 68-70, 73. Iremos sempre nos referir a essa entrevista a partir do áudio fornecido por Ivan Cardoso à autora.

${ }^{30} \mathrm{O}$ manuscrito de Oiticica data o texto "Brasil Diarréia" como tendo sido escrito de 5 a 10 de fevereiro de 1970. cf. PHO 0328/70 - anexos. O catálogo da exposição retrospectiva de 1992-93 (Hélio Oiticica. Catálogo da exposição itinerante 1992-1997. Roterdã: Witte de With Center for Contemporary Art; Paris: Galerie Nationale du Jeu de Paume; Barcelona: Fundació Antoni Tàpies; Lisboa: Centro de Arte Moderna da Fundação Calouste Gulbenkian; Minneapolis: Walker Art Center; Rio de Janeiro: Centro de Arte Hélio Oiticica. ) não menciona a data do manuscrito, o que causa certa confusão pois menciona apenas "Publicado em Arte Brasileira Hoje, Rio de Janeiro, 1973". Trata-se de uma publicação desse texto em GULLAR, Ferreira (org.) Arte brasileira hoje: situação e perspectivas . Rio de Janeiro: Paz e Terra, 1973, p. 147-152.
} 
usava o verbo "inventar" com menos rigor, como por exemplo num texto de 1967 no qual critica a "febre de inventar" dos artistas. A invenção é, nesse texto, uma palavra usada de forma pejorativa. Oiticica menospreza a produção dos "artistas", que sempre tentam superar-se uns aos outros com "invenções insólitas e outras pragas esteticistas" e enaltece a produção coletiva, que integra artistas e público, como o Parangolé Coletivo ${ }^{31}$. A influência do momento político aparece na expressão "toque de reunir", uma transformação do "toque de recolher". Ironicamente, recolher significa tanto abrigar em isolamento quanto juntar partes espalhadas, reunir. É importante notar que Oiticica valoriza o público e o popular sem referência às propostas de arte social dos Centros Populares de Cultura da UNE ${ }^{32}$. A tônica popular, em Oiticica, é convocada no combate às "pragas esteticistas" da arte erudita e no seu exercício de “desintelectualização."

Surge então o programa que considero definitivo: o PARANGOLÉ COLETIVO, nas ruas do Rio, em breve a ser posto em execução (...) Aqui deve haver total liberdade de invenção e criação possibilitada pela proposição de um 'toque de reunir' (...) O ponto ainda recalcitrante em manifestações da chamada vanguarda é considerar a arte como uma segunda natureza (...) Ficam então os artistas numa permanente febre de " inventar", o que se resume em criar transformações permanentemente nas abordagens formais, estruturais, semânticas, das obras criadas anteriormente. Aparece então o processo de 'seringação' ou 'chupação' mútua, ou seja, um procura superar o outro em tais transformações, a maioria delas por imitação ou simples plágio, porque nem todos possuem imaginação criativa ou dela já secaram (...) mas a proposição de criação ilimitada baseada no processo de imaginação, por manifestações livres, poria por terra

${ }^{31}$ cf. FAVARETTO, Celso. A Invenção de Hélio Oiticica. (1992) 2a. ed.. São Paulo: Editora de Universidade de São Paulo, 2000, p. 118 e 135. Para Favaretto, "o interesse por práticas populares não implica recurso à valorização, dada naquele momento, à "cultura popular", com ênfase em "raízes populares" (...) Mantendo-se embora afastado dos projetos culturais que figuravam a "realidade nacional", como etapa da ação política que reagia à dominação do imperialismo e do regime militar, Oiticica respondeu à sua maneira aos apelos dessa esquerda (...) O Parangolé é assim a produção daquele ponto em que se desfaz a contradição do inconformismo estético e do inconformismo social (...) Para Oiticica, arte e política são práticas convergentes, mas que não se confundem, sob pena de se promover a estetização da política." Ainda sobre a relação de Oiticica com o popular, cf. ASBURY, Michael. "O Hélio não tinha Ginga" in Fios Soltos: A Arte de Hélio Oiticica, BRAGA, Paula (org.) São Paulo: Perspectiva, 2007(no prelo).

${ }^{32}$ Sobre os CPCs, cf. ZILIO, Carlos. "Da Antropofagia à Tropicália" em NOVAES, Adauto (org.) $O$ Nacional e o Popular na Cultura Brasileira. São Paulo: Brasiliense, 1982. cf. também MARTINS, Carlos Estevam. "Anteprojeto do Manifesto do CPC" em Arte em Revista ano 1, no.1, 1979, p. 67-79 e MARTINS, Carlos Estevam. "História do CPC" em Arte em Revista ano 2, no.3 , 1980, p. 77-82. 
essa ainda exclusividade de obras ou 'invenções' insólitas, e outras pragas esteticistas - o artista seria o promotor de tais manifestações que para se completarem só com o povo seria possível. Que beleza - não esperar "soluções geniais" ou "novas invenções" de $\operatorname{artistas}^{33}$.

Na década de 1970, depois da leitura do livro de Pound, o inventor passa a ser para Oiticica exatamente o propositor de transformações. Até mesmo o plágio, que no trecho acima de 1967 é característica de um artista medíocre, é pintado com nova cor branco -- na década seguinte: as carreiras de cocaína desenhadas por cima de figuras são um "plágio" do desenho que encobrem, satirizando uma preocupação de artistas "carreiristas":

A COCA que se dispõe em trilhas acompanha o pattern design que lhe serve de base: uma espécie de démi-sourrire para o q se conhecia por plágio (...) faz-nos pensar com sarcasmo DUCHAMPIANO quão longe e passados estão todos os conceitos q caracterizavam o caráter de "autenticidade" nas artes plásticas: o plágio é gratuito e não mais importa pois só um imbecil sem imaginação e alienado pobre de espírito poderia colocar o q se poderia caracterizar como competitividade como o núcleo motor de sua atividade criadora (ou o q for) (...) a COCA q se camufla plagiando o desenho-base não faz crítica do conceito mas brinca com o fato de q essa oportunidade de brincar haja surgido -- as considerações carreirísticas e submissão a valores de pequena burguesia e petty discussions de quem fez isso ou aquilo primeiro (...) são provenientes de hang-ups de classe sexo resíduos infantis etc. ${ }^{34}$

A palavra "invenção" aparece também em textos de Oiticica como título das pinturas monocromáticas feitas a partir de 1959. É interessante notar que essas "invenções" foram pintadas em sucessivas camadas de cor, cerca de três ou quatro, e que cada cor era feita pela mistura de várias tintas de marcas diferentes. ${ }^{35}$ Recapitulando as transformações da palavra "invenção", Oiticica diria a Ivan Cardoso em 1979 que partiu das "Invenções" para chegar à "Invenção"36.

Os laços que Oiticica estabelece com sua "família de inventores" são mais inesperados e intrincados do que uma descendência linear, não se enquadram em um

\footnotetext{
${ }^{33}$ OITICICA, Hélio. Sem título, 02/04/1967. AHO e PHO 0018/67. Publicado em GAM, n. 6, Rio de Janeiro, maio de 1967.

${ }^{34}$ OITICICA, Hélio. "Bloco-Experiências em Cosmococas - programa in progress.” AHO 301.74

${ }^{35} \mathrm{PHO} 0191 / \mathrm{sd}-3 / 7$

${ }^{36}$ OITICICA, Hélio. Entrevista a Ivan Cardoso. op. Cit. p. 71, confrontado com áudio.
} 
modelo de mestre-discípulo, tampouco de continuidade de um legado. A relação de Oiticica com outros inventores é também marcada por um movimento de "negação do passado". Não se trata de um revival dos inventores do passado - trata-se de retorno de singularidades, ou "singultaneidades"37, neologismo que Oiticica cunha em uma carta para Haroldo de Campos, em 1974, na qual comenta a forma como Haroldo de Campos construiu um poema-homenagem ${ }^{38}$ a Hélio Oiticica, Parangol(h)elium, atravessando diferentes idiomas, justapondo Heráclito, Sousândrade, Byron, Motokiyo Zeami (autor da peça de teatro Nô Hagoromo $^{39}$ ) e o próprio Oiticica.

sua página-homage é não só algo q me assombra como algo q cresce mais e mais cada vez q me detenho nela: eu com minha ignorância até grego decifrei sem saber origem ou língua: como diz POUND primeiro o sonorear antes de procurar entender significados outros (...) cresço-crescem: genealogicamente e jamais como 'algo que dá em alguma coisa': seria assim como 'algo q gera e se gera em faces-confronto' (...) bloco-faz-bloco: no confronto da página (...) fragmentação livre da vontade de 'fazer um poema': mútuo scrapear: cada medida verbal é YEs em relação à outra: YESSYING SIMULTÂNEO: VOILÀ!: SINGULTÂNEO (q termo full of pregnancies não?) (...) child harold seu brincar enriquece de joy mais do q nosso privilégio de ter acesso a ele: enriquece aquilo q se diria ser o dia-a-dia: bem NÔ: claro beyond all considerations of language or species (...) assim como lendo CATULO quem poderia dizer q LATIM seja uma 'língua

\footnotetext{
${ }^{37}$ No artigo "Hélio Oiticica, Haroldo y Augusto de Campos: el diálogo velado - La aspiración a lo blanco" (ainda não publicado), Gonzalo AGUILAR discute o termo "singultâneo" em relação ao vínculo estabelecido entre Oiticica e os irmãos Campos: "El vínculo no es de deuda ni de subordinación: hay un potenciamiento mutuo, un choque de fuerzas (to scrap es forcejear), una doble afirmación de singularidades simultáneas que se encuentran en la misma encrucijada. Un encuentro genealógico (Oiticica leía denodadamente a Nietzche por esos años), es decir de sendas embrolladas y garabateadas, de percepión de las singularidades, en un estado de invención." Numa chave Nietzschiana, Aguilar lê o "scrap" como um confronto ou somatório de forças. "Scrap" é também "fragmento" e, ao discutir com Haroldo de Campos o confronto afirmativo de blocos de pensamento, Oiticica pode estar brincando com o duplo sentido da palavra. Cf. também o uso da palavra "scrap" em OITICICA, "Homage to My Father", op.cit., reproduzido acima.

38 "Parafernália para Hélio Oiticica", que Haroldo de Campos escreveu em 1979 para ser lido no filme HO de Ivan Cardoso, cita uma estrofe de "Parangol(h)elium" (CAMPOS, Haroldo de. "Parangol(h)elium" em LUCCHETTI, R. F. Ivampirismo : o cinema em pânico. Rio de Janeiro: Editora Brasil-América, Fundação do Cinema Brasileiro, 1990, p. 65-66) que é um dos vários documentos analisados por Gonzalo Aguilar que atestam a proximidade das obras de Oiticica e dos irmãos Campos nos anos 1970. cf. AGUILAR, "Hélio Oiticica, Haroldo y Augusto de Campos: el diálogo velado - La aspiración a lo blanco" (ainda não publicado) e AGUILAR, Gonzalo. "Na Selva Branca: o Diálogo velado entre Hélio Oiticica e Augusto e Haroldo de Campos" em Fios Soltos: A Arte de Hélio Oiticica. BRAGA, Paula (org.), op.cit.

39 Haroldo de Campos escreveu em um artigo para a Folha de S. Paulo em 16/02/1992 a respeito dos parangolés: "Comparei-os uma vez ao 'manto de plumas' - 'Hagoromo' - da peça nô de Motokiyo Zeami (1363-1443), traduzida por Pound via Fenollosa, e que eu mesmo vim a transcriar de maneira hiperpoundiana em nossa língua: peça dança, poema dançado". cf. CAMPOS, Haroldo de, "O Músico da Matéria", Folha de S. Paulo, caderno Ilustrada, 16/02/1992.
} 
morta': sequer considerar tal coisa já seria negar ter lido CATULO ou 'entrado na dele' (...) news that STAYS news seria ou não isso?

"Singultâneo", "yessing simultâneo", é a afirmação simultânea, e a afirmação é a singularidade de qualquer época. Mesmo vinda do passado, a singularidade continua presente (news that stays news), exatamente como um ponto de luz no céu, estrela que talvez não exista mais no momento em que sua luz nos atinge.

O passado interessa a Oiticica por conter inventores e assim, fazer parte de um presente denso, que não é o instante, mas um tempo extenso, que dura até o instante presente e dele faz parte. $\mathrm{O}$ que interessa é o campo de experimentalidade e não da história linear.

Os textos de Oiticica do início da década de 1960 mencionam muito a vanguarda construtiva européia, não como uma ancestralidade e sim como "pontos de luz", momentos de explosão do novo. Conforme explicitado por Favaretto ao estabelecer a relação de Oiticica com as experiências construtivas do Cubismo, Maliévitch e Mondrian, não há em Oiticica um movimento de "descendência":

[o] salto de Oiticica, da pintura para o espaço e para a criação de "novas ordens", funda-se nessa constelação básica de referências [Cubismo, Maliévitch e Mondrian]; entretanto, não é aprisionado por visada que privilegia o movimento de descendência (...) Assim, a constelação de referências básicas não esgota a multiplicidade de contribuições, proveniente de artistas, tendências ou grupos. ${ }^{40}$

A descendência implica em avanço linear e cronológico. A "singultaneidade", distinção no pensamento de Oiticica, compõe inovação e convivência atemporal de singularidades.

\footnotetext{
${ }^{40}$ FAVARETTO, Celso. A Invenção de Hélio Oiticica, op.cit. p.34. Para a discussão sobre o sentido de construção na obra de Oiticica, confira o capítulo de onde extraímos essa citação: FAVARETTO, "Margens do Programa" in . A Invenção de Hélio Oiticica. op.cit. pp. 27-45.
} 


\section{3 "Singultâneo": o retorno do que avança}

Newyorkaises surgiu no ninhos do primeiro loft de Oiticica, espaço que o artista nomeou de Babylonests, ${ }^{41}$-- "nome dado tendo ainda como fascínio fácil New York como Babilônia"42. Guy Brett descreve a simultaneidade de sons que embalava os ninhos de Babylon:

O Babylonest era uma estrutura de dois ou três andares (não me lembro bem) que preenchia todo o espaço de seu pequeno apartamento. Havia pequenas cabines com cortina, colchão, etc. Hélio ocupava uma delas. Havia também uma cozinha e um banheiro separados. Nunca soube muito bem quantas pessoas viviam ali, pois a toda hora tinha alguém entrando ou saindo (...) Quando estive em Nova Iorque, Hélio trabalhava à noite como telefonista internacional (...) Ele voltava do trabalho às sete da manhã, dormia um pouco, e então procurava sua máquina de escrever. Gostava de ter tudo funcionando ao mesmo tempo em seu ninho: máquina de escrever, rádio, gravador, televisão, telefone, etc., e brincava comigo porque eu preferia o silêncio. ${ }^{43}$

Uma coincidência que nos convém ressaltar é que Oiticica admirava o livro em que Nietzsche apropriou-se do mais famoso personagem babilônico, Zaratustra:"“Assim Falou Zaratustra' é um dos maiores livros já escritos. Aí está Nietzsche em toda a sua genialidade! Sua influência na arte de hoje é clara. Nutro por ele a mais profunda admiração; foi um grande gênio."

$\mathrm{Na}$ filosofia de Nietzsche, o mundo é um bloco auto-contido, finito, no qual a impermanência, o eterno fluir, ocorre sem escapar para um suposto "lado de lá" ou para uma área vazia e recém gerada. Para Nietzsche, o eterno fluir aliado à finitude é o retorno: "que tudo retorne é a mais extrema aproximação de um mundo do vir-a-ser como

\footnotetext{
${ }^{41}$ LAGNADO, Lisette. op.cit. p. 124 ; "Lá [Nova Iorque], contorna o problema do dépaysement: instaura o que poderíamos chamar de repaysement, nomeando seus lofts - Babylonests (de 1971 a 1974) e Hendrixst (de 1974 a 1978)"

${ }^{42}$ OITICICA, Hélio. ntbk 1/73 p. 48, 12/junho/1973

${ }^{43}$ BRETT, Guy. Brasil Experimental; arte/vida: proposições e padadoxos, MACIEL, Katia (org.). Rio de Janeiro: Contra-Capa, 2005, p. 20, 22

${ }^{44}$ OITICICA, notas sem título e sem data, AHO 0279.sd e PHO 0279/55
} 
ser" ${ }^{45}$. O círculo impede a finalidade, é "a forma que bloqueia o sentido." ${ }^{46}$ Bloqueando a intenção, a finalidade, e garantindo a repetição, a idéia do retorno eterno do mesmo garante a transformação pois suscita o não-programa, o pensamento que rompe com teleologias e determinismos.

Nos arquivos de Oiticica, dentro de uma pasta chamada Newyorkaises há uma fotocópia de trechos dos fragmentos póstumos de Nietzsche, dentre os quais se lê:

If the world may be thought of as a certain definite quantity of force and as a certain definite number of centers of force - and every other representation remains indefinite and therefore useless - it follows that, in the great dice game of existence, it must pass through a calculable number of combinations. In infinite time, every possible combination would at some time or another be realized; more: it would be realized an infinite number of times. And since between every combination and its next recurrence all other possible combinations would have to take place, and each of these combination conditions the entire sequence of combinations in the same series, a circular movement of absolutely identical series is thus demonstrated: the world as a circular movement that has already repeated itself infinitely often and plays its game in infinitum." ${ }^{47}$

\footnotetext{
${ }^{45}$ cf. frag. post. 7 (54) do final de 1886/primavera 1887 apud. MARTON, Scarlett. "A Terceira Margem da Interpretação" em MÜLLER-LAUTER, A Doutrina da Vontade de Poder em Nietzsche. S. Paulo: Annablume, 1997, pg. 46.

${ }^{46}$ KOSSOVITCH, Leon. Signos e Poderes em Nietzsche. (1979). 2a ed. Rio de Janeiro: Azougue Editorial, 2004, p. 136

${ }^{47}$ NIETZSCHE, Friedrich. The Will to Power. KAUFMANN, Walter (ed.). New York, Vintage Books, 1968, p. 548. (fragmento 1066). Citaremos sempre os fragmentos póstumos de Nietzsche a partir dessa edição, que é a mesma que Hélio Oiticica usava. Para as traduções para português desses fragmentos, usaremos sempre que possível NIETZSCHE, Friedrich. Obras incompletas. Gerard LEBRUN (org.), Rubens Rodrigues Torres Filho (trad.). $3^{a}$ edição. São Paulo: Abril Cultural, 1983 (Coleção Os Pensadores)
}

"Se o mundo pode ser pensado como grandeza determinada de força e como número determinado de centro de força - e toda outra representação permanece indeterminada e conseqüentemente inutilizável --, disso se segue que ele tem de passar por um número calculável de combinações, no grande jogo de dados de sua existência. Em um tempo infinito, cada combinação possível estaria alguma vez alcançada; mais ainda: estaria alcançada infinitas vezes. E como entre cada combinação e seu próximo retorno todas as combinações ainda possíveis teriam de estar transcorridas e cada uma dessas combinações condiciona a seqüência inteira das combinações da mesma série, com isso estaria provado um curso circular de séries absolutamente idênticas: o mundo como curso circular que infinita vezes já se repetiu e que joga seu jogo in infinitum."(cf. Nietzsche, Obras incompletas, op. cit, p. 396 (fragmento 1066)). 
Nos textos publicados por Nietzsche em vida, o eterno retorno não é necessariamente uma tese cosmológica $^{48}$ mas sim possibilidade experimental de pensamento. Como salientado por Scarlett Marton, na "Gaia Ciência", texto que introduz a teoria do eterno retorno na obra de Nietzsche, a idéia de um mundo cíclico é apresentada na forma condicional, bem menos determinística do que nos fragmentos póstumos citados acima, como uma suposição: ${ }^{49}$

E se um dia ou uma noite um demônio se esgueirasse em tua mais solitária solidão e te dissesse: 'Esta vida, assim como tu a vives agora e como a viveste, terás de vivê-la ainda uma vez e ainda inúmeras vezes; e não haverá nela nada de novo, cada dor e cada prazer e cada pensamento e suspiro e tudo o que há de indizivelmente pequeno e de grande em tua vida há de te retornar, e tudo na mesma ordem e seqüência (...) $)^{50}$

Nietzsche está aqui propondo uma experiência com os modos de pensar a existência: "Não é, sem dúvida, enquanto tese que a idéia do eterno retorno surge na Gaia Ciência - mas como experimento do pensamento." ${ }^{51}$ Se tudo é repetição aliada ao esquecimento, até mesmo esse instante em que refletimos sobre o eterno retorno pela infinitésima vez sem nos lembrarmos dos ciclos anteriores em que já o fizemos, se aceitarmos essa doutrina, como viveremos nossas vidas? "Ainda que a repetição cíclica não passe de uma probabilidade ou possibilidade, até mesmo o pensamento de uma possibilidade pode nos abalar e transfigurar." ${ }^{22}$ Quem suportaria o peso deste pensamento, de que não só o que é grande mas também o que é baixo e mesquinho retornará e que nada há além desse retorno? Como não se desesperar diante de tal suposição? Suportá-la é tão difícil que se torna uma seleção. O eterno retorno é um pensamento seletivo. Para suportá-lo é preciso ter a capacidade de não ser aniquilado pelo pessimismo que suscita. Pode-se construir uma hierarquia de conceitos na obra de Nietzsche na qual o retorno ocupa o nível mais elevado: "É a todos que Zaratustra fala da

${ }^{48}$ Scarlett Marton informa que em 1882 Nietzsche considerou a possibilidade de retornar à universidade para estudar matemática e física e assim embasar a hipótese cosmológica do eterno retorno. Cf. MARTON, Scarlett. "Eterno Retorno do Mesmo: tese cosmológica ou imperativo ético?" in Ensaios sobre a filosofia de Nietzsche. São Paulo: Discurso Editorial, 2000, p. 84.

${ }^{49}$ MARTON, Scarlett. "Eterno Retorno do Mesmo: tese cosmológica ou imperativo ético?”, p. 69

${ }^{50}$ NIETZSCHE, Friedrich. A Gaia Ciência (fr. 341), Obras Incompletas. op.cit. p. 208

${ }^{51}$ MARTON, Scarlett. “Eterno Retorno do Mesmo: tese cosmológica ou imperativo ético?”, op.cit. p. 71

${ }^{52}$ NIETZSCHE, Friedrich . Gaia Ciência, apud. KOSSOVITCH, Leon. op. cit.,p. 137 
morte de Deus; é a alguns que fala do além-do-homem e da vontade de potência; mas, no fundo é apenas a si próprio que fala do eterno retorno do mesmo." 53

Nietzsche lidou com a questão do niilismo afirmativo desde seu primeiro livro, $O$ Nascimento da Tragédia, e em diversos outros escritos confere à arte o poder de superação do niilismo. A arte, a criação, seriam encantos maiores do que o pessimismo, e portanto mais propícios à vida, conforme salientado por Oiticica: "Para NIETZSCHE a descoberta da arte (ou do q seja ela) é a descoberta de algo mais forte q o pessimismo, de algo 'mais divino' q a verdade (...)" ${ }^{94}$. Em um fragmento póstumo reproduzido na edição de The Will to Power que Oiticica usava ${ }^{55}$, Nietzsche elenca maneiras de suportar o eterno retorno do mesmo:

Maneiras de suportá-lo [o eterno retorno]: transmutação de todos os valores. Encontrar prazer não mais na certeza mas na incerteza; nem "causa" nem "efeito" mas uma criação contínua; a vontade não de conservar, mas de dominar; não mais esta humilde locução: "tudo é apenas subjetivo!", mas essa afirmação: "Tudo é também nossa obra - sejamos orgulhosos dela!"

Uma maneira de suportar o eterno retorno é a criação contínua, a generosidade de instituir uma obra passível de gerar uma conseqüência imprevisível, uma obra que deixa "fios soltos para serem explorados" $" 57$. No eterno retorno do mesmo, sobrevive aquele que inventa e não se deixa sufocar pelo pessimismo. E por conseguinte, é justamente essa singularidade produtora de invenções que retorna.

Oiticica conhecia o SIM dionisíaco transvalorador e antídoto para a sensação de aniquilamento. Em carta a Lygia Clark, brinca com o "sim" e o "sin" (pecado):

pode-se ser incompetente em tudo na vida, exceto quanto ao que fazemos! Nisso nunca! Outra vez NIETZCHE é quem diz magistralmente que o artista nunca é 'pessimista' pois mesmo na crise ele só diz

${ }^{53}$ GRLIC, Danto. "Nietzsche e o eterno retorno do mesmo ou o retorno da essência artística na arte" in MARTON, Scarlet (org.). Nietzsche hoje? Colóquio de Cerisy. São Paulo: Brasiliense, 1985, p. 31.

${ }^{54}$ OITICICA, Hélio. “O q Faço é MÚSICA”, 1979. AHO 057.79. Publicado também no catálogo da exposição. "O q Faço é MÚSICA”, Galeria S. Paulo, 1986.

${ }^{55}$ A pasta Newyorkaises armazenava fotocópias das páginas 546 a 549 da edição de The Will to Power feita por Walter Kaufmann. O fragmento que citamos está na página anterior, 545.

${ }^{56}$ Trad. da autora a partir da edição de Walter KAUFMANN. Op. Cit. "Means of enduring it: the revaluation of all values. No longer joy in certainty but in uncertainty; no longer 'cause and effect' but the continually creative; no longer the humble expression, 'everything is merely subjective,' but 'it is also our work! - Let us be proud of it!" (WP, 1059)

57 “No Brasil há fios soltos num campo de possibilidades. Por que não explorá-los.” OITICICA, Hélio. "Experimentar o Experimental", 1972. PHO 0380/72 
SIM, e a vida e a atividade dele e o terrível são abordados em uma variação de SIMS (ou SINS) longe de perdas e anéantissement [aniquilamento]. ${ }^{58}$

$\mathrm{O}$ artista trágico que Oiticica cita em seus textos ${ }^{59}$ parece ser sua versão (invenção) do além-do-homem Nietzschiano, um operador alegre e dançarino da transmutação de valores graças à sua capacidade de suportar o pensamento do retorno e de dizer o "sim" trágico e incondicional à vida, empregando a sua singularidade, seu alto grau de intensidade (vontade de potência), para suportar o eterno retorno do mesmo, que inclui o retorno do terrível.

A crença no eterno retorno constrói uma temporalidade onde o passado não remete a um passado histórico, do tempo cronológico. O passado é uma fonte de vir-aser, uma meia-noite quando os dados foram jogados para caírem na terra num grande meio-dia. O que aconteceu comigo há uma hora é meu futuro no modelo de tempo do retorno. Com isso, apaga-se qualquer possibilidade de evolução no sentido banal de anterior-posterior. Nada é "datado", julgamento ressentido e opressor, anulado pelo eterno retorno.

Invenção é invenção. Invenção é o que não pode ser diluído e não o que será fatalmente diluído, aliás, isso é muito importante dizer, é a primeira vez que eu estou formulando isso desse jeito: antigamente a invenção, depois dos inventores viriam os mestres e os diluidores, quer dizer, a invenção seria fatalmente diluída. Agora não[,] a invenção é aquilo que está imune à diluição. A invenção é imune à diluição. A invenção propõe uma outra invenção, ela é a condição do que Nietzsche chamava de "o artista trágico". A invenção ela gera invenção. O Artista Trágico [,] de uma conseqüência que ele chega, ele gera outra conseqüência, acima daquela e diferente daquela, ele nunca volta atrás para repensar uma conseqüência. Quer dizer, a invenção é a condição do "Artista Trágico" nietzschiano, isso é muito importante. (...) O experimental é

\footnotetext{
${ }^{58}$ Lygia Clark - Hélio Oiticica: Cartas, 1964-74. op.cit., p. 242. (carta de 10/10/1974)

59 "Em Nova Iorque, na metade da década, em algum notebook (consultar depois) descobri que o artista trágico Nietzscheano não existira mas que estava em processo de instauramento. SILVIANO SANTIAGO me chamou a atenção para que os filósofos franceses novos teriam abordado-restaurado NIETZSCHE para o momento: dito e feito: Caiu-me nas mãos o livro de DELEUZE sobre NIETZSCHE e só essa semana descobri-li a abordagem do artista trágico q faz: em tudo se aparelha do q vivenciei em NOVA IORQUE (...)" OITICICA, Hélio. "Memorando Caju", 1979. PHO 114/79. Como se conclui desse trecho, o interesse de Oiticica pelo "artista trágico" é de meados dos anos 1970 (cf. por exemplo "Carta para Mary e Mario Pedrosa", 28/02/1975. AHO 1411.75) mas é em 1979 que ele lê o trecho sobre o artista trágico Nietzschiano na obra de Deleuze Nietzsche e a Filosofia.
} 
justamente a capacidade que as pessoas têm de inventar sem diluir, sem copiar, é a capacidade que a pessoa tem de entrar num estado de invenção, que é o experimental (...) ${ }^{60}$

Ao mesmo tempo em que elabora sua noção de artista trágico que carrega consigo a idéia do retorno, Oiticica insiste em uma idéia de "evolução" ("o artista trágico de uma conseqüência que ele chega, ele gera outra conseqüência, acima daquela e diferente daquela, ele nunca volta atrás para repensar uma conseqüência" ${ }^{61}$ ). No Brasil, "voltar atrás" seria ainda mais inadmissível:

O Brasil, a grande vantagem do Brasil é uma coisa que Mário Pedrosa já disse há muito tempo: que o Brasil é um país condenado ao moderno. Essa coisa do Mário Pedrosa dizer que o Brasil é um país condenado ao moderno é uma coisa muito importante porque na realidade, o que ele está querendo dizer é o seguinte: que só há possibilidade de ir para frente, em outras palavras, de experimentar... que não há razão para voltar atrás no Brasil, ou fazer uma reavaliação dos valores da história da arte etc e tal, não há razão para ninguém voltar atrás. ${ }^{62}$

Não é possível entender o "ir para frente" e o "voltar atrás" de Oiticica em um modelo linear.

Sou contra qualquer insinuação de um "processo linear"; a meu ver os processos são globais - uma coisa é certa: há um abaixamento no nível crítico, que indica esta indeciso-estagnação - as potencialidades criativas são enormes, mas os esforços parecem mingalar ${ }^{63}$, justamente quando são propostas posições radicais, posições radicais não significam posições estéticas, mas posições globais vida-mundo - linguagem comportamento. Dizer-se que algo chegou "ao fim", assim como a pintura, por ex. (ou como o próprio processo linear que determina essa idéia) é importante, o que não quer dizer que não haja quem não o faça; dizer que ela acabou é assumir uma posição crítica diante de um fato, é propor uma mudança [...] ${ }^{64}$

Para Oiticica, "ir para frente" não supõe movimento em linha reta, mas numa trama. No lugar de uma "seqüência", Oiticica usa a "conseqüência". A "conseqüência" é

${ }^{60}$ OITICICA, Hélio. Entrevista a Ivan Cardoso. op.cit., confrontado com áudio. Oiticica serve-se neste trecho de categorias inventadas por Ezra Pound, como ele mesmo esclarece em outra entrevista, a Gardênia Garcia: "Antes havia o que o poeta Ezra Pound classificava como inventores, mestres e diluidores. Agora só tem razão de existir os inventores.". OITICICA, Hélio. Entrevista a Gardênia Garcia, op.cit.

${ }^{61}$ OITICICA, Hélio. Entrevista a Ivan Cardoso, op.cit., confrontado com o áudio da entrevista.

${ }^{62}$ ibid.

${ }^{63} \mathrm{O}$ verbo "mingalar" não existe em português e ocorre no manuscrito original de Oiticica e publicações subseqüentes deste texto. Foi-nos sugerido pelo Projeto HO que o verbo usado nessa frase seja "mingaular", já que mais adiante no texto Oiticica cita o "mingau da crítica d'arte brasileira".

${ }^{64}$ OITICICA, Hélio. "Brasil Diarréia”, 1970. PHO 0328/70. 
um dos vários termos que Oiticica utiliza e reelabora durante décadas. "Conseqüência" aparece em um texto de 1959 com o sentido de ciclo:

Leio estas palavras proféticas em Mondrian: "O que está claro é que não há escapatória para o artista não-figurativo; ele tem que permanecer dentro de seu campo e, como conseqüência, caminhar em direção a sua arte. Esta conseqüência nos leva, num futuro talvez remoto, em direção ao fim da arte como uma coisa separada do ambiente que nos circunda, o qual é a própria realidade plástica presente. Mas esse fim é ao mesmo tempo um novo começo $(\ldots)^{65}$.

"Conseqüência" aparece vinte anos mais tarde, no texto $O$ q Faço é MÚSICA, de 1979: "por isso com a descoberta do corpo que me veio como conseqüência da desintegração das velhas formas de manifestação artística (como conseqüência recente do programa-grito de MALEVICH na primeira metade do século: Q O REPÚDIO AO VELHO MUNDO DA ARTE FIQUE INSCRITO NAS PALMAS DE SUAS MÃOS) (...) descobri q o q faço é MÚSICA" ${ }^{\prime 66}$

Entendemos nos dois casos a "conseqüência" como caracterização de uma série de elementos aparentados pela relação que estabelecem, não necessariamente uma relação temporal "anterior-posterior", mas “evolução" no sentido coreográfico do termo: Mangueira evoluindo na avenida ${ }^{67}$. Ou, repetindo a frase que Oiticica usou para descrever Newyorkaises: "Não uma coleção de fragmentos mas fragmentos-blocos q são totalidades q se justapõem como em crescimento e não uma seqüência linear lógica." ${ }^{\text {"68 }}$ Nesse modelo de "conseqüências" que tentamos definir, uma obra relaciona-se com outras mas continua

${ }^{65}$ OITICICA, Hélio. Aspiro ao Grande Labirinto, Luciano Figueiredo; Lygia Pape; Waly Salomão (orgs.), Rio de Janeiro: Rocco, 1986, p.17.

${ }^{66}$ OITICICA, Hélio. "O q Faço é Música”, 1979. PHO 0057/79.

${ }^{67}$ Para qualificar essa seqüência na trama, ocorre-me aqui a palavra "evolução" no sentido que é usada por Teixeira Coelho: "Os valores estéticos só se percebem, em princípio, no contexto da evolução histórica de uma arte - e devo dizer que falo em evolução histórica de uma arte no sentido carnavalesco do termo, usado para descrever a passagem de uma escola de samba pela avenida (ainda que se trate da avenida artificial criada por Niemeyer): a escola de samba evoluciona pela avenida, quer dizer, vai daqui para lá e de lá para cá, dá um passo para o lado e depois um passo para o outro lado e para frente e para trás, num movimento de complexa figuração do qual são exemplos máximos a porta-bandeira e o mestre-escola. A escola de samba faz suas evoluções pela avenida mas de modo algum ela busca a cada metro de avenida ser melhor do que era um metro atrás ou diferente do que era há um metro atrás (a escola de samba deve mesmo ficar sempre igual a si mesma, mas essa é outra história). Só nesse sentido e apenas nesse sentido uso a palavra evolução quando me refiro à arte." Cf. COELHO, Teixeira, "Arte e Cultura da Arte", texto apresentado no simpósio "Padrões aos Pedaços: o pensamento contemporâneo na arte". Paço das Artes, S. Paulo, agosto de 2005.

${ }^{68}$ OITICICA, Hélio. "Vendo um filme de Hitchcock, 'Under Capricorn'”, 31/03/1974 .op.cit 
sendo única, independente, relacionada às demais por elos tênues: veios e não raízes. No texto O q Faço é MÚSICA, lê-se:

\section{é MÚSICA}

porque com a posta em cheque da obra e da razão dela foi a MÚSICA o condutor espinha-dorsal ao cerne do problema (porque a multiplicação de obras?: em vez de multiplicar obras a concepção de q ela é única): não há a tão falada evolução de uma obra para outra: cada uma é um monumento único totalmente independente da outra: (o q terá vindo "antes" ou "depois"?: na verdade há uma tal simultaneidade de raízes e veios q se erguem q não é possível saber o q veio antes ou depois: raízes criadas no ar a partir da INVENÇÃO do criador-artista e nunca as malfadadas tão faladas "raízes" e q estas sim seriam o empecilho à INVENÇÃO CRIATIVA): ao artista INVENTOR não cabe somar obras:

não existe "estilo": com DUCHAMP tudo isto já havia chegado ao limite: e com ARTAUD?: e por que buscam os artistas a unidade?: coerência? unidade? em suma querer reestabelecer o velho "estilo"!: quem não colocar em cheque o problema da obra ficará marcando passo fazendo "obras" mecanicamente: não é o q está acontecendo? (e ainda pegam DUCHAMP para modelo! $)^{69}$

Buscar uma unidade estilística, isto é, amarrar a obra a uma "seqüência" coerente sufoca a invenção com uma repetição rala, uma soma de obras. "Não existe "estilo": com DUCHAMP (e com Artaud, que retirou-se dos palcos durante viagens e internações em hospitais psiquiátricos) tudo isto já havia chegado ao limite. Aqui Duchamp é citado não como pai do ready-made, mas como um oponente da seriação de obras, como já fora citado em 1971, logo no início da estadia de Oiticica em Nova Iorque:

é preciso estar livre da amarras do consumismo, ou seja, da demanda de produção de obras exigida pelo mesmo: a art-scene geral do mundo de hoje parece submergir na repetição enfadonha (...) por isso no contexto de livro de luxo-arte, livretos, toda sorte de comentários magazínicos, pasmam-se com o fato de um artista como Duchamp passar horas, dias, anos, jogando xadrez sem produzir $(\ldots)^{70}$

Em novembro de1974, Oiticica menciona o "intermezzo" de Duchamp para jogar xadrez como uma oportunidade de gestar, para conseqüente afloração. No mesmo texto

\footnotetext{
${ }^{69}$ OITICICA, Hélio. "O q Faço é MÚSICA”, PHO 0057/79

${ }^{70}$ OITICICA, Hélio. "HO NYK sept. 1, 71: anotações para serem traduzidas para inglês: para uma próxima publicação" PHO 0271/71.
} 
de 1974, Oiticica reflete sobre novas formas de arte que coloca em prática, como o sexo e o "dealing"", ao lado do ler, escrever, fazer planos-plantas-projetos:

Onde estou NOW? Exatamente?: numa morte lenta?: no conforto cokeificado do boiling pot (não "melting": BOILING!) em q ferverei qual lagosta esperneante?: q ato cumprirei para a tomada do PODER:? Q PODER?: EU AO TOPO DE CONSEQÜÊNCIAS MINHAS? Como onde em q parte

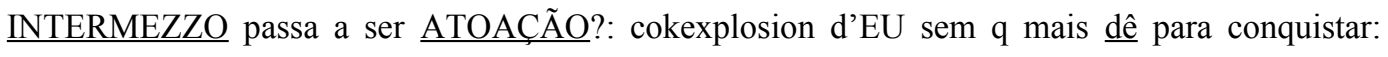

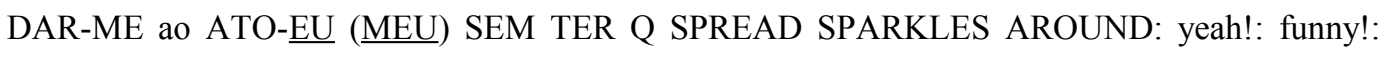
porque perguntar tudisso aqui no pad-pag (...) é porque não adianta simular q por trás de tudo estão grandes idéias ou projetos nobres ou etc.: estão e não estão: porque já o dealing se tornou

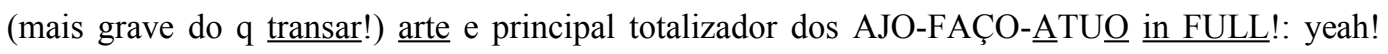
Creative?: bullshit!: assim como se posso aproximar a tomada de fôlego DUCHAMPIANA do

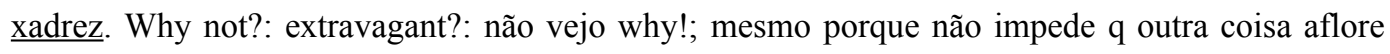
mais floreante!: assim como aqui escrever p. ex. e ler!!: e mesmo assim lançar-planos-plantasprojetos!! q são aflorações $!^{72}$

\footnotetext{
${ }^{71}$ O "dealing" citado nesse fragmento provavelmente é a venda de cocaína. Nos anos 1970, em Nova Iorque, Oiticica estava bastante envolvido com o uso de cocaína, como fica claro em suas cartas a Lygia Clark, nas quais o artista refere-se à droga como "prima": "Sinto-me como se tivesse dormido um ano e acordado com uma cafungada de pó (da PRIMA: quando eu disser PRIMA já sabe, é nossa velha amiga COCAÍNA; coisas de nobreza incaica à qual pertenço; como FREUD” (CLARK, Lygia e OITICICA, Hélio. Lygia Clark - Hélio Oiticica: Cartas, 1964-74, op.cit., p. 226 (carta de 11/07/1974)). "São umas $7 \mathrm{~h} 15 \mathrm{~min}$ da manhã e estou desde $2 \mathrm{~h}$ da tarde movendo-me; hoje tudo foi ótimo e resolvi impasses desses dias passados; essas duas semanas foram nem lá nem cá e tive que solucionar mil e um probleminhas de dinheiro, etc. Mil loucuras que não posso dizer aqui; tudo legal porém, legal no ilegal, morou? Estava quase falido e fiz bastante em poucos dias (como sempre); coisas de NEW YORK e impossíveis de serem comentadas por escrito; e estou hoje experimentando um novo vestido de baile da PRIMA". (ibid., p. 236, 10/10/1974). Esse estreito relacionamento com as drogas no período em que viveu em Nova Iorque é um dos assuntos mais delicados no estudo da obra de Oiticica. O comentador não pode ser apologético tampouco trair-se em moralismos. Então usualmente aborda-se esse assunto após a ressalva de que as drogas nos anos 1960 e 1970 tinham um caráter libertador e de experimentalismo muito distinto da associação contemporânea de drogas com violência e tráfico. Essas ressalvas confirmam a extemporaneidade desse assunto, ainda tabu no século 21, mas parece-nos insatisfatório encobrir a discussão com a "aura hippie" das drogas como parte de uma geração sonhadora e rebelde. O ambiente das drogas em Nova Iorque nos anos 1970 talvez fosse diferente do universo contemporâneo do tráfico no Brasil, mas nem por isso menos violento. O consumo de drogas já era um assunto de interesse de Oiticica pelo menos desde 1969, quando conta para Lygia Clark que estava lendo Naked Lunch, de William Burroughs, "que se desintegra de tal forma que só suporto ler algumas páginas de cada vez" (ibid., p. 134, 23/12/1969). Em carta datada de 30 de setembro 1978 para Olympio Vasconcelos, Oiticica, de volta ao Rio, declara seu total afastamento da cocaína: "A Prima foi aposentada por mim sem pensão: não a quero ver nem pintada: virei atleta: corro na ponta dos pés para exercitar os músculos do tornozelo daqui até o COUNTRY onde fico uma hora e nado (...)." AHO 1495.78
}

72 OITICICA, Hélio. “Scorpionias”, 07/11/1974. PHO 0148/74. "Melting pot” é uma expressão (atualmente questionável) usada nos Estados Unidos para caracterizar a cultura americana como uma mistura homogênea de outras culturas. Oiticica substitui o "melting” (derretimento) por "boiling" (fervura). 
Gertrude Stein, a quem Marcel Duchamp dedicou a obra "Why not sneeze, Rrose Sélavy” (1921), também é invocada por Oiticica para seu argumento sobre a pausa. Oiticica cita de Everybody's Autobiography uma frase sobre o "preguiçar criativo": "leva-se muito tempo para se tornar um gênio. É preciso sentar e ficar fazendo nada, realmente fazendo nada"73. Gertrude Stein é ainda bloco que no pensamento de Oiticica encaixa a pausa e o retorno: "Se um som, repetido num crescendo de intensidade então pára, quantas vezes poderá ser repetido", frase da palestra "Poetry and Grammar" citada em "Experimentar o Experimental", de 1972. ${ }^{74}$

Oiticica explicita ao final da série de notas que tomou sob o título de "Scorpionias", a diferença entre conseqüência e continuidade. Continuidade é comparada a um engatamento, seriação, ganchos (cliff hangers), como o ápice que termina cada episódio de um seriado de televisão, que tem um enredo e finalmente chega ao fim. Oiticica quer transformar sua tomada de fôlego em conseqüência, algo inesperado, não em gancho para o próximo passo calculado:"Nov. $1074 \rightarrow$ but this ain't no CLIFF

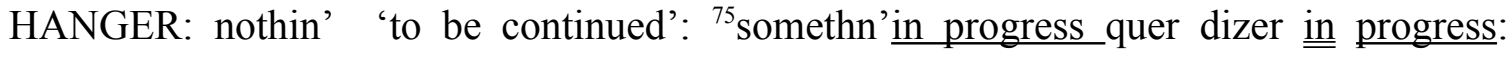
CLIFF HANGERS são 'seriados': in progress são INVENÇÕES q se consequentizam e não CLIFF HANGING continuidades!"”76

Consequentizar são várias seqüências ocorrendo simultaneamente, nas várias atividades de um indivíduo. Não separar a produção artística de Duchamp de seus jogos de xadrez, pois ambos são fios simultâneos que se conseqüentizam.

E prá governo de todos os burrões q "querem saber o q eu fiz em Nova Iorque além dos desbuns já sabidos" e de outros imbecilóides q dizem q "parei durante estes anos de produzir obras" porque por obra entendem essas porcariazinhas q são expostas várias vezes por ano em galerias e museus: em Nova IORQUE cheguei e consolidei o hábito e a realidade de q obras e produção

\footnotetext{
${ }^{73}$ OITICICA, Hélio, anotação em notebook, 16/10/1974. Tradução livre da autora. PHO 315/74 (título atribuído pelo Programa HO: "Lendo Gertrude Stein")

${ }^{74}$ Além de inserir essa frase em "Experimentar o Experimental", de 1972, op. cit, Oiticica usa essa frase também em anotações datilografadas sobre performance em outubro/1971, citando como referência a palestra de Stein "Poetry and Grammar" (cf. PHO 241/71). A mesma frase com a referência aparece em OITICICA, Hélio. ntbk 1/73, p. 10.

75 "mas isso não é nenhum gancho: nada "a ser continuado": algo in progress quer dizer in progress"

${ }^{76}$ OITICICA, Hélio. "Scorpionias". op.cit.
} 
são muito mais do q multiplicar obras ou inflacionar as mentes humanas com ideiazinhas chatas!: e não é isso q faz a maior parte dos chamados "artistas plásticos"? ${ }^{77}$

Conseqüentizar é também admitir a simultaneidade de inventores, a "singultaneidade". Assim como existe em Hélio o inventor do parangolé e o experimentador de vários tipos de cocaína, ${ }^{78}$ há uma diversidade de outros inventores que reaparecem ao longo de sua obra, e Hélio estica o fio deixado por cada um deles para uma nova conseqüência.

${ }_{77}$ OITICICA, Hélio. "O outro lado do rio", 08/12/1978, AHO 0092/78

78 "Dou sempre uns nomes e sei que você vai curtir; por exemplo: um dia apareceram com algo que denominei NEM TUDO Q RELUZ É OURO porque o brilho de paetê nesse caso não será bem do puro mas de algo acrescentado (entende?); essa nova, que é do melhor pano do mundo, é NEVES DE KILIMANDJARO; uma outra do mês passado ainda superior a tudo que já vi é IVORY GIRL(...)" CLARK, Lygia e OITICICA, Hélio. Lygia Clark - Hélio Oiticica: Cartas, 1964-74, op.cit., p. 237. $(10 / 10 / 1974)$ 


\subsection{Branco: cor tempo}

Oiticica associa o estado de invenção à cor branca e ao "branco sobre branco" de Maliévitch:

(...) o branco não é só um quadro do Malevitch, o branco com branco é um resultado de invenção, pelo qual todos têm que passar; não digo que todos tenham que pintar um quadro branco com branco, mas todos têm que passar por um estado de espírito, que eu chamo branco com branco, um estado em que sejam negados todo o mundo da arte passada, todas as premissas passadas e você entra no estado de invenção ${ }^{79}$

O branco sobre branco aponta um caminho para percorrer a obra de Oiticica, desde a pesquisa sobre a cor da virada da década de 1950 para 1960 (branco-luz) até a relação do artista com tóxicos (branco-coca). A referência a Maliévitch é também particularmente importante para evidenciar, no pensamento de Oiticica, a negação da arte do passado, a transmutação da arte.

A rejeição do velho mundo da arte abre o ensaio "On New Systems in Art", escrito por Kasimir Maliévitch em 1919: "que o repúdio ao velho mundo da arte fique inscrito nas palmas de suas mãos" ${ }^{\$ 0}$, frase que Oiticica usa em ao menos dois textos de 1979, “O q Faço é MÚSICA" e "Memorando Caju”.

Em “On New Systems in Art”, Maliévitch defende que a arte crie signos distintos dos estabelecidos pela arte do passado. Rejeitar o "velho mundo da arte" homologava-se a rejeitar a velha ordem social.

É somente formando signos de nossa criação que avançamos e nos distanciamos do passado, e portanto não podemos estabelecer beleza eterna com nossas novas invenções (...) nós crescemos e nosso crescimento altera nossa condição, portanto um retorno ao passado é inconcebível: não há uma só idéia, uma só iniciativa que possa trazer esse retorno e abordar a arte sob a bandeira do passado, ou alcançar hoje o que foi alcançado ontem, porque a vida cresce, e seu crescimento

\footnotetext{
${ }^{79}$ OITICICA, Entrevista a Ivan Cardoso, op. cit., confrontado com o áudio da entrevista.

80 "Let rejection of the old world of art be traced on the palms of your hands" MALEVITCH, K. S. "On new systems in art" in_Essays on Art: 1915 - 1933 vol. 1. Xenia Glowacki-Prus e Arnold McMillin (trad.), ANDERSEN, Troels (ed.) (London; Chester Springs, Pa. : Rapp \& Whiting: Dufour Editions, 1969), p. 83.
} 
é visível no novo padrão da forma que se desenvolve. Sua diferença em relação ao passado é inerente na nova forma. (..) A arte avança inexoravelmente. ${ }^{81}$

Para Oiticica, importava acima de tudo que a arte incitasse uma transformação ético-comportamental. Pode-se dizer que, para Oiticica, a atitude política das vanguardas dos anos 1960 no Brasil, traça "uma imagem da arte como atividade em que não se distinguem os modos de efetivar programas estéticos e exigências ético-políticas (...) a posição crítica e a atuação cultural requeridas pelo momento faziam coincidir o político e a renovação da sensibilidade; a participação social e o deslocamento da arte." ${ }^{~}$

Rejeitar a arte do passado como mote "inscrito nas palmas das mãos" significava, para Oiticica, a ação artística norteada pela busca de um novo comportamento, descondicionado de repressões sociais e não-repressor ele mesmo. A rejeição ao velho mundo da arte estaria inscrita tanto nas mãos do artista quanto do participador: espectador imbuído de ação. Essa ênfase no comportamento seria um marco zero ${ }^{83}$ na reinvenção da arte proporcional ao radicalismo da pintura Suprematista do branco sobre o branco.

"Branco no Branco" é o título de um dos blocos de Newyorkaises, homenagem à inauguração, detonada por Maliévitch, de "algo estranho ao processo criador ocidental -> não desconhecido: estranho: tão conhecido do oriental." $" 84 \mathrm{O}$ elemento estranho introduzido por Maliévitch foi, para Oiticica, a "premonição da descoberta do corpo / primeira aparição do comportamento como elemento maior / não espectador: a impossibilidade do espectador como tal. ${ }^{"} 5$

${ }^{81}$ MALEVITCH, K.S., op.cit., p. 85 e 89 . Tradução da autora.

${ }^{82}$ FAVARETTO, Celso "Inconformismo social, inconformismo estético, Hélio Oiticica" in Revista Gaia. São Paulo, USP, Ano I, n. 2 , set-dez. 1989, p. 24-32. Republicado na revista Educação e Filosofia. Universidade Federal de Uberlândia, v. 4, n. 8, jan-jun. 1990, p. 151-158 e em Fios Soltos: a arte de Hélio Oiticica. BRAGA, Paula (org.) São Paulo: Perspectiva, 2007 (no prelo).

${ }^{83}$ cf. PIGNATARI, Décio. "Marco Zero de Andrade" em O Estado de São Paulo, Suplemento Literário 24/10/1964: "Alguns tem a volúpia e a coragem do zero, do de onde se começa (...) São os criadores originais, radicais, de uma linguagem nova, irreversível aos termos de um regime anterior, ininteligível mesmo em meio a uma linguagem pré-existente já estratificada em código (...) As autênticas vanguardas artísticas contemporâneas têm-se caracterizado por sua 'anti-arte', desde o 'rien ou presque un art' de Mallarmé, passando pelo movimento 'Dada' e por Oswald de Andrade até a poesia concreta (...)"

${ }^{84}$ OITICICA, Hélio. "Branco no Branco", 28/05/1974 PHO 095/74

${ }^{85}$ Ibid. 
Temos aqui o Maliévitch de Oiticica, feito apenas dos fragmentos que interessam ao brasileiro, a saber o radicalismo da reinvenção da arte. Não há no Suprematismo essa ênfase no corpo que Oiticica deriva dos textos de Maliévitch. Partir do Suprematismo e chegar ao corpo foi uma "conseqüência" alinhavada por Oiticica. É certo que o artista russo defende a abolição do objeto como modelo para representação e radicaliza a pintura abstrata ao mergulhar na pintura não-objetiva. No entanto, o Suprematismo de Maliévitch desvincula o "sentimento" dos sentidos -- "o [artista] Suprematista não observa e não toca, ele sente" ${ }^{\text {"86 }}$ ou ainda "sentimento não-objetivo tem sempre sido, de fato, a única fonte possível de arte." ${ }^{.87}$

Por Suprematismo eu entendo a supremacia do puro sentimento (feeling) ${ }^{88}$ na arte criativa. Para o Suprematista, os fenômenos visuais do mundo objetivo são, neles mesmos, insignificantes; a coisa significante é o sentimento, como tal, bastante separado do ambiente no qual ele é invocado (...) O sentimento é o fator determinante... e então a arte chega a representação não-objetiva - ao Suprematismo. Ela alcança um "deserto" no qual nada pode ser percebido, exceto o sentimento (...) Suprematismo é a redescoberta da arte pura que, no curso do tempo, tornou-se obscurecida pela acumulação de “coisas" (...) O quadrado Suprematista e as formas dele derivadas podem ser ligadas às marcas primitivas (símbolos) do homem aborígene que representavam, em suas combinações, não ornamento mas um sentimento de ritmo. ${ }^{89}$

Oiticica, no entanto, pode ter lido esse texto em tradução para o português que no lugar de "feeling" (sentimento) usou "sensibilidade", conforme publicado no Jornal do Brasil em 1959, palavra que implica em uma ênfase maior nos aspectos sensoriais do que "sentimento." Nessa tradução para português, lê-se:

\footnotetext{
${ }^{86}$ MALEVITCH, K.S.. "Suprematism" in Theories of Modern Art, CHIPP, H.B. (ed.) Berkeley, Los Angeles and London: University of California Press, 1984, p. 345. Tradução da autora desta versão em inglês onde se lê: "the Suprematist does not observe and does not touch - he feels"

${ }^{87}$ Ibid., p. 346 "Nonobjective feeling has, in fact, always been the only possible source of art"

${ }^{88}$ Usamos uma tradução para o inglês do texto de Maliévitch, na qual a palavra usada nesse trecho é feeling.

${ }^{89}$ Ibid., p. 341-344. tradução livre da autora a partir da versão em inglês onde se lê: "Under Suprematism I understand the supremacy of pure feeling in creative art." A tradução para o inglês continua a usar sempre "feeling" e "feels" e nunca "sensibility" or "senses". Grifo nosso.
} 
Por Suprematismo entendo a supremacia da pura sensibilidade na arte. Do ponto de vista dos suprematistas, as aparências exteriores da natureza não apresentam nenhum interesse:

essencial é a sensibilidade em si mesma, independentemente do meio em que teve origem. ${ }^{90}$

É interessante que o Maliévitch traduzido para o português em 1959 -- auge da querela dos concretistas e neo-concretistas sobre o corpo e ano da publicação do Manifesto Neo-concreto -- enfatiza a "sensibilidade". A tradução para o inglês enfatiza o "sentimento", a emoção abstrata. ${ }^{91}$

Oiticica não menciona em seus textos o sentimento e sim o sensorial e o comportamento. Os "fenômenos do mundo objetivo," inclusive os visuais - que Maliévitch descarta na tradução para o inglês -- são fundamentais para o programa ambiental do brasileiro. Vale notar ainda que a obra de Maliévitch que marcou a virada do Cubo-Futurismo para o Suprematismo é o Quadrado Negro, de 1913, porém, é a série "Branco no Branco" que Oiticica escolhe, poundianamente, para seu repertório de "espécimes". Branca é a tela antes da pintura, um zero, um vazio, prenhe de possibilidades. O branco, para Oiticica, é a cor luz síntese de todas as outras cores. Pound também associava o branco a reunião de cores: "Pound, num esplêndido tour de force, lê compriso bianco no sentido de 'compreendido no seu todo', clarificado por uma luz total ('todas as cores unidas no branco'), remetendo ao verbo imbiancare, usado por Dante no Paradiso [...] Transculturação sincrônica. Maliévich: branco no branco." ${ }^{.92}$

O branco está nas duas pontas do espectro contínuo de conceitos sobre a cor que Oiticica desenvolve ao longo de duas décadas, desde os monocromáticos brancos de 1960

\footnotetext{
${ }^{90}$ Jornal do Brasil, 1959 apud. Projeto Construtivo Brasileiro na Arte: 1950-1962. AMARAL, Aracy (org.) Rio de Janeiro, Museu de Arte Moderna; São Paulo: Pinacoteca do Estado, 1977, p. 32. O texto nesse livro termina com a seguinte referência: "Transcrito do Jornal do Brasil, 1959, s.d."

${ }^{91}$ Uma análise comparativa de traduções dos textos de Maliévitch e Kandinsky para inglês e português e consequências das traduções nas obras de artistas brasileiros seria um trabalho revelador e que ainda está para ser feito. Textos sobre o Suprematismo na língua inglesa enfatizam os aspectos espirituais da obra de Meliévitch e não sensoriais, como a tradução para o português publicada no Jornal do Brasil sugere.

${ }^{92}$ CAMPOS, Haroldo de. Pedra e Luz na Poesia de Dante, Rio de Janeiro: Imago, 1998. apud. AGUILAR, Gonzalo. "Na Selva Branca: o diálogo velado entre Hélio Oiticica e Augusto e Haroldo de Campos" in Fios Soltos: a Arte de Hélio Oiticica. BRAGA, Paula (org.) São Paulo: Perspectiva, 2007 (no prelo).
} 
até os grandes penetráveis concebidos no final de sua vida, tais como Invenção da Cor, de 1977, e Invenção da $L u z^{93}$, de 1978-80.

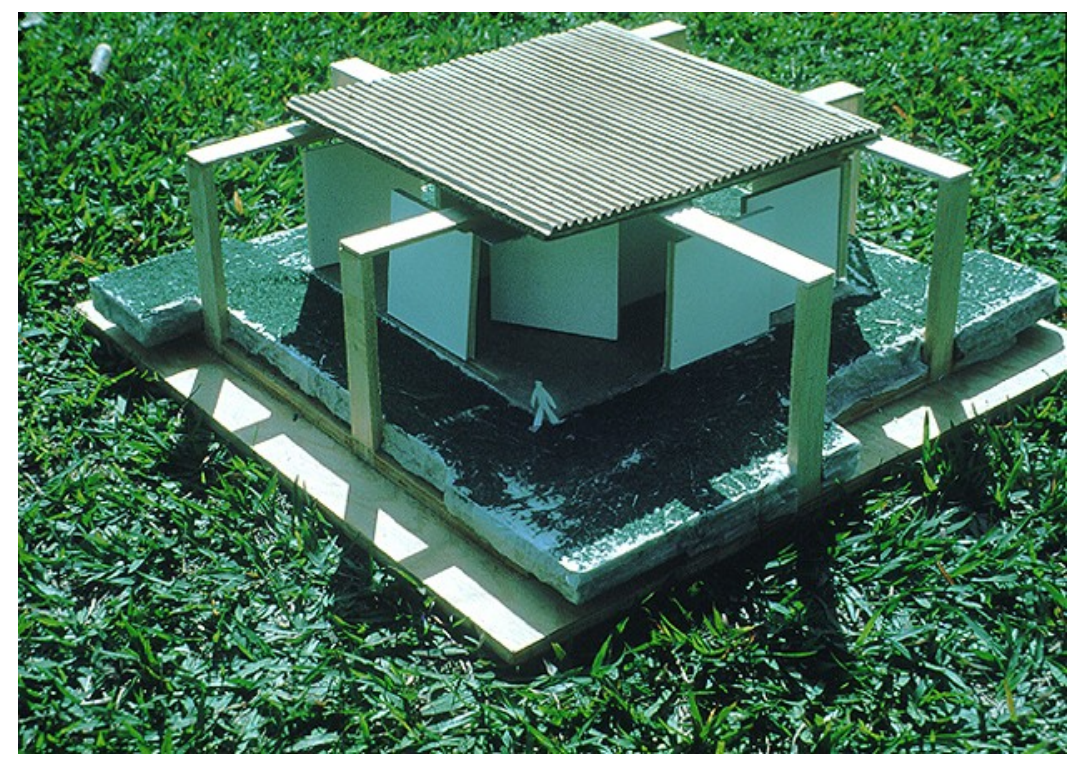

Invenção da cor, Maquete para penetrável Magic Square 1, 1977

(...) nessas coisas que eu chamo de invenção da cor, eu procuro usar a cor mais racionalmente. $\mathrm{Na}$ realidade, elas sempre foram luminosas para consumir, era uma tentativa da estrutura na qual ela era pintada, quer dizer a parte física do objeto, ele fosse consumido pela cor, ele fosse inflamado pela cor, por isso mesmo eu usei a palavra Bólide para os Bólides, que eu tive essa idéia quando eu vi um filme do Humberto Mauro, Ganga Bruta, em que as pessoas usam roupa brancas e a roupa branca refletia a luz, então ele iluminava as pessoas vestindo de branco, porque havia deficiência de luz, ou sei lá o que, então as pessoas rolavam, assim, por um gramado, vestidos de branco e pareciam Bólides... Aí eu pensei assim, pareciam bólides... ah na realidade o que eu estou fazendo são bólides, eu quero transformar as coisas que eu estou fazendo, consumir elas de luz através da cor. ${ }^{94}(1979)$

\footnotetext{
${ }^{93}$ Em carta a Olympio Vasconcelos de 30 de setembro de 1978, Oiticica escreve: "Fiz uma maquete complicada e super bem feita e precisa. Faz parte de uma experiência A INVENÇÃO DA COR e será construída no Parque Ecológico do Tietê em S. Paulo. Isto é, se o Maluf não for eleito porque senão vai construir a nova capital de S. Paulo e todo dinheiro vai ser canalizado para isso!!!”

${ }^{94}$ OITICICA, Hélio. Entrevista a Ivan Cardoso, op. cit., com alterações a partir da comparação com o áudio da entrevista.
} 
O branco, nesse trecho, marca sua relação com o bólide: junção de todas as cores, inflama com luz e transforma a estrutura. Cor luz, nos textos de Oiticica, são aquelas às quais se pode dar um "sentido de luz", especificamente o branco, amarelo, laranja e vermelho luz.

O branco é a cor luz ${ }^{95}$ ideal, síntese luz de todas as cores. É a mais estática, favorecendo assim a duração silenciosa, densa, metafísica. O encontro de dois brancos diferentes se dá surdamente, tendo um mais alvura que o outro $(\ldots)^{96}$

A cor luz não é a cor prismática da física, que divide o espectro eletromagnético em diferentes comprimentos de onda e a cada faixa de comprimento associa o nome de uma cor. Essa definição de cor exclui a "duração", conceito de Bergson importante para o entendimento da cor luz de Oiticica, depois chamada de cor tempo, cor metafísica ou cor ativa. A cor que interessa a Oiticica leitor de Bergson" ${ }^{97}$ é a cor "pura como ação", imbuída de movimento, aquela que o intelecto - afeito a decompor o todo para analisá-lo em estados imóveis -- não apreende. Assim, quando pinta suas Invenções em camadas sucessivas de cores, das quais nosso intelecto apreende apenas a camada mais externa, Oiticica aponta a limitação do entendimento especulativo. Uma “invenção" não é simplesmente amarela ou vermelha: é um todo construído a partir de camadas e camadas variadas.

A cor metafísica (cor tempo) é essencialmente ativa no sentido de dentro para fora, é temporal, por excelência. Esse novo sentido da cor não possui as relações costumeiras com a cor da pintura

\footnotetext{
${ }^{95}$ No manuscrito datilografado que usamos de "Cor, Tempo e Estrutura" (AHO 015.60), Oiticica diz "cor luz" e "síntese luz". Na publicação desse texto em OITICICA, Hélio. Aspiro ao Grande Labirinto, op.cit., lê-se "cor-luz" e "síntese-luz", com hífen, na página 45. Já no manuscrito de "Cor Tempo" (AHO 017.59), Oiticica opta pelo hífen e grafa "cor-luz".

${ }^{96}$ OITICICA, Hélio. "Cor, Tempo e Estrutura", sem data, c. 1960. AHO 015.60

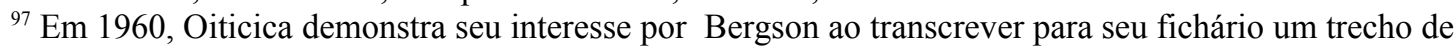
“Matéria e Memória"(PHO 0182/59. Cf. também PHO 0014-59 que é outra versão da primeira página desse documento, com pequenas variações que conduzem o leitor a um entendimento mais completo das reflexões de Oiticica sobre o tema da "duração" da cor. ):"Para obter a transformação do corpo ou da imagem em representação, não é necessário, por isso, 'iluminar o objeto', 'mas obscurecer ao contrário certos lados, diminuí-lo da maior parte de si mesmo, de maneira que o resíduo, em vez de ficar encaixado naquilo que o rodeia, como uma coisa, dele se desprenda, como um quadro." Essa passagem está em BERGSON, Henri . Matéria e Memória: ensaio sobre a relação do corpo com o espirito. S. Paulo: Martins Fontes, 1990, p. 24-5. Não sabemos se Oiticica leu realmente esse texto de Bergson ou se o citou a partir de algum comentador.
} 
no passado. Ela é radical no mais amplo sentido. Despe-se totalmente das suas relações anteriores, mas não no sentido de uma volta à cor-luz prismática, uma abstração da cor, e sim da reunião purificada das suas qualidades na cor-luz ativa, temporal. Quando reúno, portanto, a cor na luz não é para abstraí-la e sim para despi-la dos sentidos [esvaziá-la dos sentidos passados], conhecidos pela inteligência, para que ela esteja pura como ação, metafísica mesmo. Na verdade o que faço é uma síntese e não uma abstração (...) a estrutura vem juntamente com a idéia da cor, e por isso se torna, ela também, temporal. Não há estrutura a priori, ela se constrói na ação mesma da cor-luz. ${ }^{98}$

O contraponto da "síntese", nesse trecho, não é a análise, mas sim a "abstração". A cor prismática é considerada "uma abstração" pois foge da concretude da cor como matéria e adentra o campo do conhecimento intelectual e especulativo, ou seja, das abstrações. A “síntese", ao contrário, favorece o conhecimento sensório e intuitivo.

Como pode a cor ser percebida para além do campo especulativo? Olho uma cor e penso "amarelo". Oiticica quer incitar uma percepção para além de um pensamento classificatório da "cor da cor", uma percepção que mergulhe na "cor pura como ação." A ênfase que Oiticica confere ao tempo nos textos dessa época, sugerem-nos que ao falar da "cor pura como ação" Oiticica esteja se referindo a suas leituras de textos de Henri Bergson, e conferindo à cor uma "duração" (e não apenas uma "extensão" no plano do quadro). Essa é a cor-tempo.

Para Bergson, "durar" é atravessar mudanças de estados contínuos. Tudo que tem existência psicológica, tem duração, isto é, transforma-se continuamente, num "escoamento sem fim" que em nada se assemelha a uma justaposição de estados fixos, a forma preferida com que nosso entendimento tenta compreender o movimento de mudança. A duração é um fluir, um estado desembocando no outro.

$\mathrm{O}$ entendimento tem dificuldade em lidar com a continuidade que constrói a mudança, mas Bergson ressalta que o ser humano é dotado não só de intelecto mas também de intuição, capacidade que temos para compreende que a duração é o "próprio tecido de que a realidade é feita"99. A duração, para Bergson, pode ser atribuída também a

${ }^{98}$ OITICICA, Hélio. Cor-Tempo, Dezembro de 1959. PHO 0017/59 publicado em . Aspiro ao Grande Labirinto, op.cit. p.16-17 sem título e sem a frase que colocamos entre colchetes a partir da consulta ao manuscrito.

${ }^{99}$ BERGSON, Henri. A Evolução Criadora, op.cit., p. 295 
existências às quais o intelecto geralmente não associa uma consciência: "O universo dura. Quanto mais aprofundarmos a natureza do tempo, melhor compreenderemos que duração significa invenção, criação de formas, elaboração contínua do absolutamente novo."100

Para Oiticica, a cor-tempo colocaria o homem em contato com a revelação de uma dimensão da vida abafada pelo intelecto:

A cor é a revelação primeira do mundo. Ela existe como luz, diluída nas aparências. A cor na pintura porém é sintética, não diluída, possui sentido próprio.(...) a preferência dos pintores pelas cores de croma alto e puras é justamente essa necessidade de escapar à relatividade das coisas, pois a cor raramente existe como croma alto na natureza. A cor passa, pois, a construir mundo, vontade suprema do artista, aspiração altamente humana. A cor é a síntese, o elemento de conciliação entre o homem e a natureza, mas não a cor da natureza e sim a cor criada pelo homem, na obra de arte (...) que se quer com a cor? Afirmar ou se perder? Apenas vivê-la. ${ }^{101}$

"A cor-luz é a síntese da cor; é também seu ponto de partida." 102 Podemos entender a "síntese", em Oiticica, como o ápice concreto de um processo de investigação, que se transforma em ponto de partida para uma nova invenção, tal como a pesquisa sobre a cor dos primeiros anos da década de 1960 transformou-se na invenção dos bólides. Mesmo em 1979, a síntese continua sendo o oposto da abstração: além de fusão orgânica que desafia a análise de partes, a síntese desafia a abstração por ser a concretização de uma idéia: ao escrever sobre Rijanviera montado no Hotel Méridien no Rio de Janeiro, Oiticica dirá que ele é um “jardim-síntese para um ambiente fechado: não uma 'representação de jardim' mas um amálgama-jardim puramente inventado" 103 . Da

\footnotetext{
${ }^{100}$ BERGSON, Henri. A Evolução Criadora, op.cit., p. 12

${ }^{101}$ OITICICA, Hélio. Sem título, setembro de 1960. AHO 121.60-p16 e p17

${ }^{102}$ OITICICA, Hélio. Sem título, maio de 1960,___. Aspiro ao Grande Labirinto, op.cit., p. 18

${ }^{103}$ OITICICA, Hélio. "Para press-release do MÉRIDIEN”, 25/05/1979, AHO 1752.79
} 
mesma forma, o parangolé que em 1964 era uma aspiração ao mito, torna-se a "situaçãoconcreção" do Parangoplay ${ }^{104}$ no texto "Parangolé síntese"105 de 1972:

\begin{tabular}{|l|l|}
\cline { 2 - 2 } \multicolumn{1}{c|}{ PARANGOLÉ-SÍNTESE } & é não-nostálgico \\
\hline de estados míticos & \\
\hline vestir a capa é & concreção \\
\cline { 2 - 2 }
\end{tabular}

PERFORMANCE

DANÇA

PARANGOLÉ-PLAY

Paródia do "artista sério"

do performer

PARANGOPLAY

A "síntese" parece indicar um "estado para além" do que o intelecto, cuja tendência é analisar partes isoladas, atingiria. Assim, em 1960 a cor síntese é algo para além da cor prismática e em 1979 a MÚSICA - em especial o rock - é a "síntese da conseqüência da descoberta do corpo". Oiticica chega então a outra síntese, também mencionada no texto de 1979 "O q Faço é MÚSICA”, que é a síntese das artes, anunciada por Kandinsky: “as 'paredes' existentes entre as diferentes artes continuam a desaparecer - SÍNTESE --, e a grossa parede entre a arte e a ciência vacila - A GRANDE SÍNTESE." 106

\footnotetext{
${ }^{104}$ Parangoplay é o título de um bloco planejado para Newyorkaises com instruções para "play de situações limites" a partir da noção de capa-clothing como extensões do ambiente. A capa dissolve-se no ambiente total, como o manto de plumas no poema Hagoromo dissolve-se no céu do céu: passa a ser extensão tanto do corpo quanto do ambiente. cf. OITICICA, Hélio. ntbk 2/73, em especial p. 79-88 e instruções para o parangoplay "Bosta get lost" nas páginas 118-123. O próximo capítulo discute o Parangoplay em mais detalhe.

${ }^{105}$ OITICICA, Hélio. "Parangolé Síntese", 1972. AHO 201.72. Publicado em Hélio Oiticica. Catálogo da exposição itinerante 1992-1997. Roterdã: Witte de With Center for Contemporary Art; Paris: Galerie Nationale du Jeu de Paume; Barcelona: Fundació Antoni Tàpies; Lisboa: Centro de Arte Moderna da Fundação Calouste Gulbenkian; Minneapolis: Walker Art Center; Rio de Janeiro: Centro de Arte Hélio Oiticica. p. 165-167

${ }^{106}$ KANDINSKY, Wassily . "O Valor de uma Obra Concreta" in , Do Espiritual na Arte. S. Paulo: Martins Fontes, 1996, p. 271.
} 
Haroldo de Campos escreveu que "a arte-música, a 'plasmação' de Hélio Oiticica, é um estado da matéria." 107 Essa definição traduz a mobilidade e transformabilidade das proposições que vão mudando, plasmando-se em novos corpos. Na "síntese" de Oiticica há sempre um processo de "trans-corporificação", uma transformação do corpo, onde o corpo condicionado é substituído por um corpo liberto - não abruptamente mas após um processo de desaguamento de uma conseqüência em outra. É isso que acontece com a cor quando, no início dos anos 1960, se liberta do corpo-estrutura que era o quadro e lança-se a um novo corpo-estrutura no espaço e nos pigmentos em pó dos bólides. Oiticica afirma que buscava uma "forma inapreensível". Um trecho do diário de 1961 é particularmente esclarecedor ao invocar Goethe e a questão do sublime: ${ }^{108}$

Goethe: (...) A sublimidade, se há de ser despertada em nós por coisas exteriores, tem que ser 'informe' ou consistir de 'formas inapreensíveis', envolvendo-nos numa grandeza que nos supere... Mas assim como o sublime se produz facilmente no crepúsculo e na noite, que confundem as figuras, assim também se desvanece no dia, que tudo separa e distingue; (...) Acho esse parágrafo no momento exato em que sinto em mim toda a inquietação e mobilidade do 'sublime'. Goethe é genial em suas observações. E o que desejo, na exteriorização da minha arte, não serão as 'formas inapreensíveis'? ${ }^{109}$

A continuação dessa anotação de Oiticica esclarece que a 'forma inapreensível' é uma forma móvel, portanto ativa ou dotada de duração no sentido Bergsoniano: uma forma inapreensível pelo intelecto que tudo congela, isola em partes, analisa.

Só assim consigo entender a eternidade que há nas formas de arte; sua renovação constante, sua imperecibilidade, vêm desse caráter de "inapreensibilidade"; a forma artística não é óbvia, estática no espaço e no tempo, mas móvel, eternamente móvel, cambiante. ${ }^{110}$

Um arte móvel, cambiante, feita de formas inapreensíveis (pelo intelecto condicionado pelas velhas formas de arte) detonaria uma espécie de "sublime", aqui entendido como um vislumbre, sensorialmente obtido, a respeito daquilo que há para ser

${ }^{107}$ CAMPOS, Haroldo de, “O Músico da Matéria”, Folha de S. Paulo, 16/02/1992.

${ }^{108}$ Sobre a questão do sublime em Hélio Oiticica, cf. AGUILAR, Gonzalo. "Na Selva Branca: o diálogo velado entre Hélio Oiticica e Augusto e Haroldo de Campos", op. cit.

${ }^{109}$ OITICICA, Hélio. Sem título, 21 de janeiro de 1961, . Aspiro ao Grande Labirinto, op.cit., p. 26 ${ }^{110}$ Ibid. 
percebido no mundo para além do que a percepção condicionada permite. Não há dúvidas quanto à natureza sensorial e a "fidelidade à terra" da experiência do sublime aspirada por Oiticica. Esse sublime - que será chamado de "supra-sensorial" a partir de 1967 desvinculando-o ainda mais de um transcendentalismo descorporificado-- é buscado nos canais perceptivos do corpo.

Dotar a cor de luz - duração -- é o início da busca pelo sublime supra-sensorial. A cor é o elemento que melhor iria conferir mobilidade, e assim inapreensibilidade intelectual, às formas artísticas.

A experiência da cor, elemento exclusivo da pintura, tornou-se o eixo mesmo do que faço, a maneira pela qual inicio uma obra.(...) A cor é uma das dimensões da obra. É inseparável do fenômeno total, da estrutura, do espaço e do tempo, mas como esses três, é um elemento distinto, dialético, uma das dimensões. Portanto possui um desenvolvimento próprio, elementar, pois é o núcleo mesmo da pintura, sua razão de ser. Quando, porém a cor não está mais submetida ao retângulo, nem a qualquer representação sobre esse retângulo, ela tende a se "corporificar"; torna-se temporal, cria sua própria estrutura, que a obra passa então a ser o “corpo da cor" (5/10/1960)

Na busca pelo "núcleo" da cor, pela duração da cor, Oiticica fez amarelos, brancos, vermelhos e alaranjados flutuarem para fora do plano da parede. A cor saiu para o espaço nos planos suspensos dos bilaterais, núcleos e nas placas dos penetráveis.

O desenvolvimento nuclear que procuro não é a tentativa de amenizar os contrastes (...) mas de movimentar virtualmente a cor, em sua estrutura mesma (...) O desenvolvimento nuclear, antes de ser dinamização da cor é a sua duração no espaço e no tempo. É a volta ao núcleo da cor, que começa na procura da sua luminosidade intrínseca, virtual, interior, até o seu movimento do mais estático até a duração. (...) a cor começou a tomar a forma de um desenvolvimento a que eu chamo de nuclear; um desenvolvimento que fosse como se a cor pulsasse de seu estado estático para a duração; como se ela pulsasse de dentro do seu núcleo e se desenvolvesse (...) Seria não só pulsação ótica como realização de aspirações indeterminadas que só aí posso exprimir. (...) É uma realização existencial no mais alto sentido da palavra. (17/03/1962)

Ao lançar a cor para fora do retângulo, Oiticica envolve o espectador numa nova experiência com a obra de arte. Conferir à cor uma dimensão especial na obra acarreta como conseqüência a criação de uma nova percepção do que seria o espectador: “o 
espaço gerado pelos Bilaterais é ativo e ativante; determina uma relação entre superfícies e espaço extra-quadro, implica o espectador como participante, altera os comportamentos habituais da experiência estética." ${ }^{111}$ Esticando o fio da cor no caminho que começa com as experiências do Suprematismo do branco sobre branco, Oiticica chega ao corpo, ao participador, ao comportamento como chaves da experiência estética.

“O comportamento - eis o que me interessa: como alçá-lo à máxima liberdade”, diria Oiticica em “À Busca do Suprasensorial”"112, de 1967. A participação não deveria ser um "novo esteticismo" mas uma concreta mudança de comportamento que liberasse uma instância criadora no indivíduo e a participação ativa em sua própria vida. "Da participação inicial, simples, estrutural, à sensorial, ou à lúdica (da maior importância), tende-se a chegar à própria vida - à participação interior na própria vida diária."113

Logo no início do texto, Oiticica descreve o instante em que se toca o novo comportamento graças à união "por incidências, por certas contingências" de "corpo e subjetividade":

uma levitação como se os obstáculos mentais e físicos não existissem: é um momento, um instante único, que quando em vez sentimos - um gozo cósmico. Um meio-dia de verão, onde o corpo, ao contrário do quente, esteja fresco e a cabeça vazia de problemas, uniforme - feliz. ${ }^{114}$

Ao longo do texto, Oiticica discorre sobre efeitos psíquicos - no sentido de integração corpo-mente -- de substâncias intoxicantes e propõe que investigar o efeito dos tóxicos poderia dar pistas sobre a possibilidade de uma "arte" causadora também de efeitos supra-sensoriais.

Continuamos aqui no mesmo registro de expansão do entendimento que orientou as experiências com a cor-tempo no início da década de 1960. O alargamento das formas de compreensão do mundo para além do exercício intelectual e para além da submissão

\footnotetext{
${ }^{111}$ FAVARETTO, Celso. op.cit. , p. 61

${ }^{112}$ Usamos um manuscrito de Oiticica em que a palavra é grafada sem o hífen: suprasensorial. A mesma grafia é usada no manuscrito de "Aparecimento do Suprasensorial na Arte Brasileira", que foi publicado com alteração na grafia em OITICICA, Hélio. Aspiro ao Grande Labirinto, op.cit.. Usaremos a grafia original das fontes consultadas nas citações e "supra-sensorial" em nosso próprio texto. É interessante notar que em março de 1968 Hélio Oiticica tentou registrar como "marca" a palavra "suprasensorial" cf. "Certidão de busca no D.N.P.I. (Departamento Nacional de Propriedade Industrial). AHO 1594.68-p2.

${ }^{113}$ OITICICA, Hélio. "À Busca do Suprasensorial”, 10/10/1969. PHO 0192/67 8-9

${ }^{114}$ Ibid.
} 
dos sentidos ao intelecto conduziria a uma proximidade com o núcleo do processo de criação e à possibilidade de criação do novo: não uma "nova obra de arte" mas um novo entendimento de mundo. O supra-sensorial seria uma expansão dos sentidos na qual "a experiência se alça por sobre o objeto da mesma, se subjetiva, liberando supersensações, originais, míticas, nunca antes movidas." Quer Oiticica provocar a junção única entre sentido e subjetividade em cada indivíduo, num efeito da obra de arte que "só com algo paralelo podemos comparar." Os elementos paralelos que se aproximariam da arte incitadora de estados supra-sensoriais seriam a música rítmica, o mito, a dança e o efeito de tóxicos e de elementos hipnóticos. Oiticica considera que para chegar à arte incitadora do supra-sensorial seria necessário uma investigação que começasse por explorar esses elementos paralelos "abrir um parênteses e criarem-se experiências paralelas, ousar algo afim ao que quer o artista."

Ainda que certas situações como estados místicos ou a embriaguez do ritmo ou "revelações criativas" possam levar ao estado supra-sensorial, tais vivências ocorrem impremeditadamente.

São contingentes e não ocorrem ao serem provocadas intencionalmente. Já o efeito de tóxicos agem direta e de modo infalível como liberadores suprasensoriais: estes nos interessam de verdade. As sensações advindas do efeito de tóxicos (...) são classicamente o que definiríamos por suprasensoriais: os sentidos são modificados por uma ação interna, na origem, que age diretamente sobre sua constituição habitual, dando-lhe uma outra dimensão, libertando poderosas vivências. Os contrários são como que intensificados, a percepção flui num supra plano, o real parece modificar-se inesperadamente.

Oiticica quer a situação controlada que provoca intencionalmente o estado supra-sensorial. Dançar pode ou não levar a um instante de alteração dos sentidos. Os tóxicos garantidamente atingem esse estado que revela uma "pista da criação"115. Pode a arte atingí-lo?

ou seria 'anti-arte', sei lá ! Não me interessam essas especificações acadêmicas - o fato é que, na busca incessante de sua raiz, de sua razão de ser, defronta a 'arte' com os mais inesperados caminhos, com novas e incessantes experiências - a busca da criação não tende a ser mais individual, mas coletiva - assim o ritmo, o tóxico-alucinógeno e outras manifestações par

${ }^{115}$ Ibid. 
excelência coletivas, surgem na ordem das coisas e delas temos que tomar conhecimento, tirando-lhe os proveitos. ${ }^{116}$

Pensando nas "experiências paralelas" de efeito detonador do supra-sensorial, que buscam a "raiz da criação," Oiticica detecta o caráter coletivo comum a todas elas. No entanto, a descoberta dessa potencialidade criativa é individual e cada um a experimenta de uma maneira diferente. Coletivizar o resultado de uma experiência suprasensorial seria criar um "novo condicionamento"117. Ao discorrer sobre o samba e a macumba, Oiticica deixa claro a importância do efeito dessas vivências no comportamento individual:

é o sensorial que atinge, no indivíduo, uma comunhão subjetiva entre indivíduos e com o ambiente (este, o ambiente, é indispensável: num ambiente sofisticado, o samba, por ex., pode modificar o ambiente mas não o suficiente para que haja a tal comunhão; é preciso que esteja no seu ambiente próprio para que viva completamente. Cada manifestação deve criar o seu ambiente, sua casca, para que viva. ${ }^{118}$

O "sentido ambiental" é assim um efeito no comportamento de um indivíduo, alcançado em experiências usualmente coletivas, pela expansão dos sentidos a um nível supra-sensorial, num ambiente específico. Como um bólide, o ambiental ocorre quando o efeito da junção indivíduo-coletivo-ambiente explode. Paredes e props, trilhas sonoras, percursos, areia, brita, constroem um ambiente mas não bastam para o "sentido ambiental."

O supra-sensorial foi uma busca, um questionamento das potencialidades da própria arte e expansão do conceito de participação. A busca foi um percurso sem um ponto de chegada final, mas com muitos achados no caminho, das experiências com a cor-tempo aos Block-experiments in Cosmococas, nos quais a cor branca descobre outra

\footnotetext{
116 Ibid.

${ }^{117}$ OITICICA, Hélio. “Aparecimento do Supra-sensorial na Arte Brasileira”, dezembro de 1967 em . Aspiro ao grande Labirinto, op.cit., p.102

$\overline{118}$ No manuscrito, Oiticica abre parenteses mas não o fecha. É interessante comparar esse trecho de Oiticica com o texto "Situational Aesthetics", de Victor Burgin que propõe uma arte que enfatize o "software" e não o " hardware". cf. BURGIN, Victor. "Situational Aesthetics". Studio International. vol. 178 n. 915

(Outubro, 1969), p. 118-21.
} 
estrutura, para além das placas suspensas no ar e pulveriza-se como cor intoxicante nas trilhas de cocaína.

O bloco-seção Cosmococa de Newyorkaises seria precedido "de fac-símile de Über Coca que atuará como um bloco-seção independente pré-Cosmococa". "Über Coca" é o título de um poema que Oiticica escreveu em junho de 1973 e também o título de um "experimento-proposição" isolado dos block-experiments in Cosmococas. Em Über Coca há lixas de unha de metal e um projetor de slides, como em "CC1 Trashscapes", mas dessa vez a projeção é só de luz branca, durante 3 minutos. A trilha sonora é a leitura do poema "freudfalado" Über Coca, de Hélio Oiticica.

"Über Coca" é o título do artigo que Sigmund Freud publicou em 1884 sobre a história da coca e usos terapêuticos como anestésico, anti-depressivo, substituto para dependência da morfina e regulador de desordens intestinais ${ }^{120}$ Neville de Almeida, em entrevista a Paulo Herkenhoff, afirmou que o artigo de Freud era "parte do programa conceitual das Cosmococas"121. Outra referência provavelmente usada por Oiticica na época em que tentava incluir a cocaína em sua pesquisa artística é o livro History of Coca: the divine plants of the Incas ${ }^{122}$ que aparece em fotografias no arquivo pessoal de Oiticica. Tanto neste livro quanto no artigo de Freud há referências a Manco Capac, o herói incaico associado à dádiva da folha de coca ao povo Inca, cujo nome inspirou o termo "Mancoquilagens" para definir as máscaras de cocaína feitas por cima das

\footnotetext{
${ }_{119}$ OITICICA, Hélio. "Übercoca”, 09/06/1973 AHO 0267.73-p2

${ }^{120}$ Freud escreveu três artigos sobre cocaína: "Über Coca" (1884), "Contribuição ao conhecimento sobre o efeito da cocaína" (1885) e "Ânsia e temor pela cocaína" (1887). Esses artigos ficaram por muito tempo fora de circulação. Em 1963, foram publicados em Viena em tradução para o inglês, em uma compilação de poucos exemplares (FREUD, Sigmund, The Cocaine Papers, Donoghue, A. K. \& Hillman, J. (org), Viena e Zurique, Dunquin Press, 1963). Em 1974, Robert Byck organizou outra compilação, com comentários da filha de Freud, Anna Freud (FREUD, Sigmund. Cocaine Papers; By Sigmund Freud. BYCK, Robert (ed.). New York: Stonehill Publishing Co., 1974). O poema de Oiticica é de 1973. No Brasil, a coletânea organizada por BYCK recebeu o título de Freud e a Cocaína. Rio de Janeiro: Espaço e Tempo, 1989. Agradeço a Beatriz Scigliano Carneiro por me ceder essa tradução. Sobre a pesquisa de Freud com cocaína, cf. também BURNS, John E. "Freud, Cocaína e sua Noiva" em http://www.rubedo.psc.br/artigosb/frdcocai.htm, acessado em 18/06/2007.

${ }^{121}$ HERKENHOFF, Paulo. "Arte e Crime” em Cosmococa Programa in progress, Buenos Aires: MALBA, 2005.

${ }^{122}$ MORTIMER, W. Golden, History of Coca: the divine plant of the Incas. Honolulu: University Press of the Pacific, 2000. A primeira edição desse livro é de 1901. Agradeço a Beatriz Scigliano Carneiro por me indicar e ceder esse livro.
} 
fotografias dos artistas que aparecem nas projeções de slide dos Block-Experiments in Cosmococa.

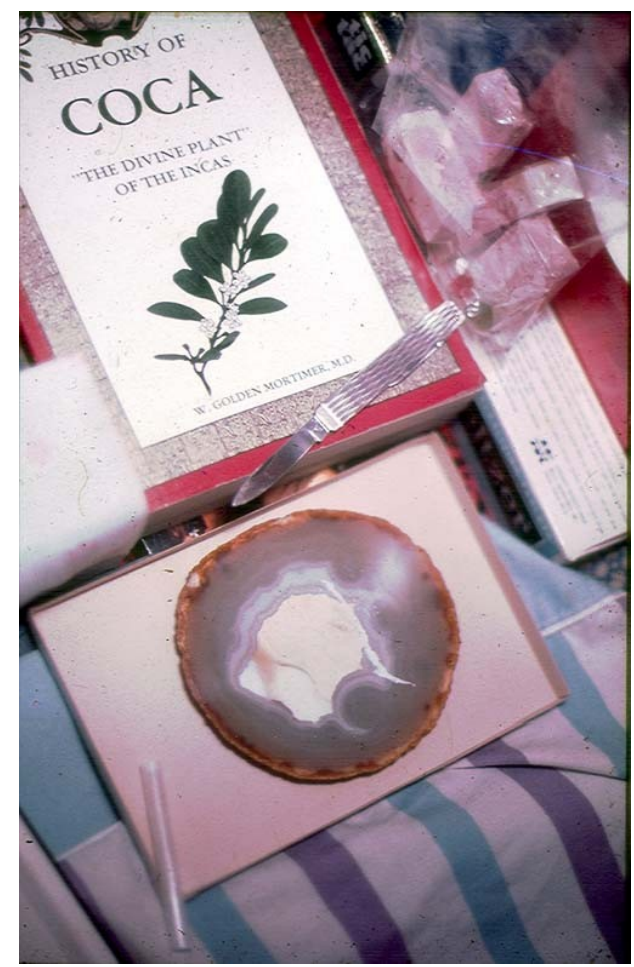

Fotografia de uma série sobre cocaína. No alto, livro History of Coca, de Golden Mortimer. AHO 2275.75-p35

$\mathrm{CC} 4$, Nocagions, é a mais branca das CCs. O branco da coca sobre o branco da capa do livro Notations de John Cage retoma o branco sobre branco. Nas anotações sobre esse block-experiment, Oiticica homenageia Maliévitch, inaugurador do espaço Suprematista, "não como um revival do Suprematismo, mas como uma asserção de sua própria existência, levada adiante de forma chance-play e cândida (puro branco)." ${ }^{\prime 23}$

Em CC4 o participador é incitado a entrar em uma piscina rasa, cercada de pequenas lâmpadas azuis. No fundo da piscina, um triângulo feito de pontos de luz verde determina a "área verde". A ponta do triângulo imerso e das facas e canivetes usados para fazer as trilhas remetem aos ângulos agudos dos Secos, guaches do final da década

\footnotetext{
${ }^{123}$ OITICICA, Hélio. "CC4 Nocagions", 24/08/1973, reproduzido no catálogo Cosmocaca programa in progress. op.cit., p. 224. Texto escrito em inglês e traduzido pela autora.
} 
de 1950, quando a cor ainda não saíra do papel. Em alguns slides, a cocaína ocupa toda a capa do livro de Cage e constrói a mesma textura das pinceladas curtas dos monocromáticos de Oiticica (as Invenções).

O participador vê as pontas secas e agudas das facas enquanto sente o não menos cortante frio da água. Acompanhada dessa sensação tátil, o branco da cocaína nos slides toma mais do que nunca aspecto de neve, o que é reforçado pelas luzinhas que inusitadamente cercam uma piscina e não uma janela, com é costume durante os meses mais frios em cidades do hemisfério norte, quando o branco da neve é iluminado à noite pela decoração das festas de final de ano. A piscina toma então o lugar da tela - quadro, canvas, screen, monitor de video, tela de trama: janela para o mundo. Marshall McLuhan, o teórico da mídia que conceitualizou "meios quentes" e "meios frios", é citado recorrentemente nos escritos de Oiticica dos anos 1972-73. O frio da piscina é a sensação tátil da frieza-abertura dos slides, no sentido proposto por McLuhan ${ }^{124}$. Em relação ao cinema, o quasi-cinema é um meio frio, com menos informação, e que exige a participação mais intensa e processos mais intuitivos do que lógicos para conduzirem ao conhecimento. $\mathrm{O}$ frio refrescante da piscina e a sensação de diminuição de peso do corpo na água relacionam-se ainda à sensação de frescor e leveza que Freud descreve no artigo "Über Coca" a respeito da ingestão de cocaína em solução oral: "Alguns minutos após ingerir a cocaína, experimenta-se uma súbita exaltação e uma sensação de leveza. Os lábios e o palato ficam saburrosos, seguindo-se sensação de calor nas mesmas áreas. Se, nesse momento, tomarmos água fria, ela parece quente aos lábios e fria à garganta. Em outras ocasiões, a sensação predominante é um frescor bastante agradável na boca e na garganta." 125 A trilha sonora com trechos de composições de John Cage sugerem também a idéia de "sons cortantes": ruídos metálicos de vários tipos, o piano preparado demanda

\footnotetext{
${ }^{124}$ cf. OITICICA, Hélio. "Bloco-Experiências em Cosmococas - programa in progress" em Hélio Oiticica. op.cit., p. 179: "segundo MCLUHAN a TV q possui menor definição visual abre brechas para q o espectador se invista em participador e preencha o q lacuneia: o cinema não: é super definido na fotografiasequência e se apresenta completo"

${ }^{125}$ FREUD, Sigmund. "Über Coca" in Freud e a Cocaína, op.cit., p. 73.
} 
esforço na junção dos fragmentos de sons ${ }^{126}$. Na piscina de CC4, esse esforço é menor, como se o corpo todo, e não só os ouvidos, se empenhasse na tarefa.

A capa do livro Notations forma em vários dos slides um losango que não se pode deixar de associar com algumas composições de Mondrian, que ao rotacionar a tela emprestou ao ângulo reto do quadrado uma ponta perfurante, aguda. Penetrável, mergulhável, azul e verde, CC4 é branco no sentido usado por Pound, depois de Dante, compriso bianco, "compreendido no seu todo" 127 pois sumariza diversas questões investigadas por Oiticica sobre a potência da arte em incitar comportamentos descondicionados e reinventar-se como arte na concretude do corpo.

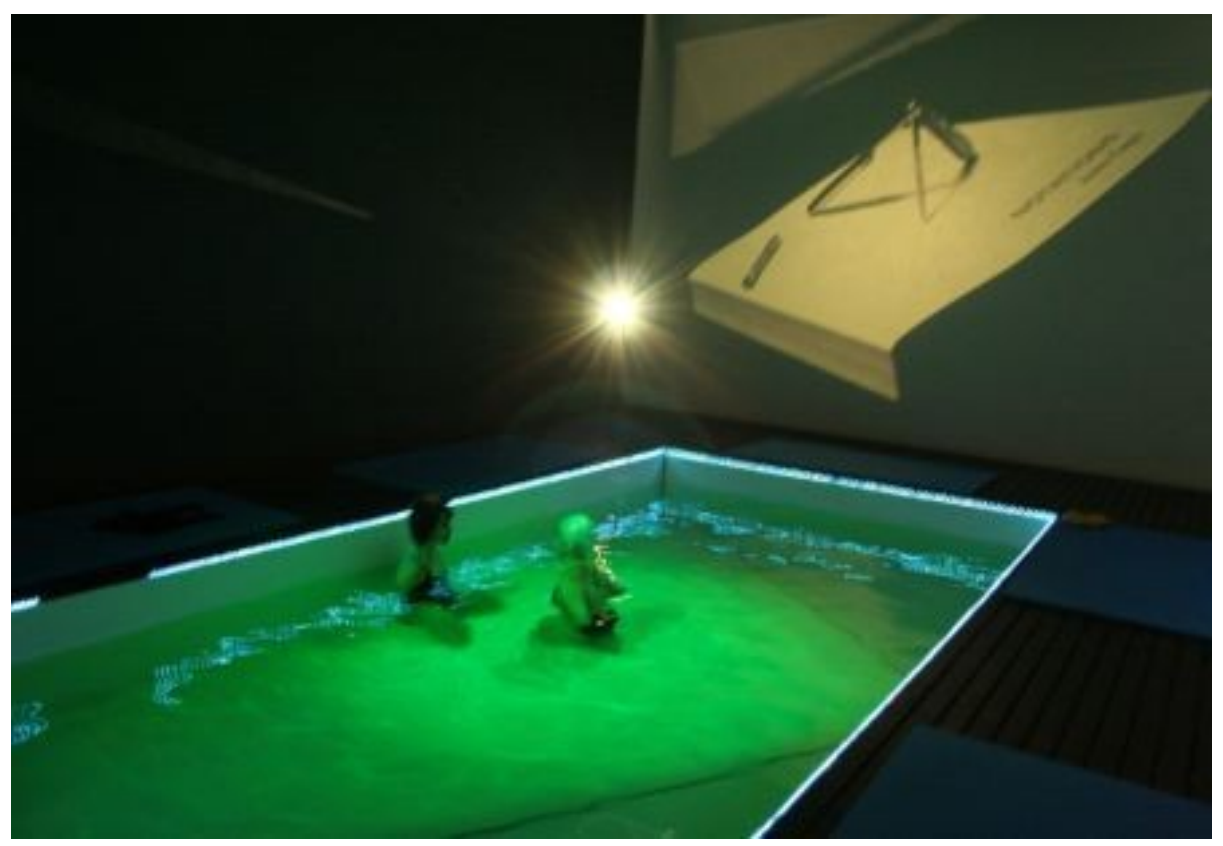

CC4, Nocations, montado em 2006 na Galeria Nara Roesler, São Paulo. Foto: Fernanda Figueiredo

\footnotetext{
${ }^{126}$ Oiticica cogitou solicitar a John Cage uma composição específica para CC4. Na montagem de CC4 que experimentamos, na Galeria Nara Roesler, São Paulo, em outubro de 2006, foram usadas peças de piano preparado de John Cage. A respeito do piano preparado, cf. CAGE, John. Silence. New England: Wesleyan University Press, 1973, p. 149: "cada piano preparado é preparado diferentemente. Objetos são colocados entre as cordas (...) Música é uma ultra-simplificação da situação em que realmente nos colocamos. Um ouvido sozinho não é um ser; música é uma parte do teatro. 'Foco' é quais aspectos alguém está notando. Teatro é todas as várias coisas acontecendo ao mesmo tempo. Tenho notado que musica é mais viva para mim quando escutar por exemplo não me distrai de ver." (trad. livre da autora)

${ }^{127} \mathrm{cf}$. nota de rodapé 92
} 
CC4 é dedicada aos "CONCRET POETS and PROSE WRITERS and THEORIZERS and above all INVENTORS: to the SÃO PAULO brothers the CAMPOS brothers AUGUSTO and HAROLDO de CAMPOS". Oiticica dedica o "compriso bianco" que é CC4 aos poetas cujas produções interceptam a de Oiticica desde a Exposição Nacional de Arte Concreta de 1956 até as experiências com a linguagem que Oiticica leva adiante em Newyorkaises, nas pontuações e formatação de seus textos, nos neologismos da década de 1970. Além do mais, Oiticica soube do livro "Notations" por Augusto de Campos:

augusto, foi genial você ter mencionado o livro do cage, notations: comprei-o, e é realmente inacreditável: de uma riqueza sem fim, cósmico, montagem fantástica; tenho lido muito o silence também, com o qual sinto uma incrível afinidade; a construção dêsses livros são obra de gênio. ${ }^{128}$

No rascunho do bloco Cosmococa de Newyorkaises, Oiticica cita uma frase do livro Silence de John Cage: "All the somethings in the world begin to sense their at-oneness when something happens that reminds them of nothing" 129 . O "nothing" de Cage é tanto "o nada" quanto "aquilo que não se parece com nada", o novo. Ao incluir no bloco Cosmococas essa alusão ao "nada/novo" como detonador de um sentimento de inteireza, Oiticica poderia estar se referindo à potência grávida do branco que, na aparente ausência de cor, reúne todas as cores. Essa suposição é reforçada pelo título do livro de Cage que contém essa frase, "Silêncio", outra forma do "nada" tão recheada quanto o branco. Para Cage, o silêncio era a parte da música não registrada na partitura, "abrindo as portas da música para os sons que por acaso estão no ambiente". ${ }^{130}$

"Nada" é o subtítulo do último dos Subterranean Tropicalia Projects, o PN16, de 1971, projetado em Nova Iorque para ser construído na Praça da República, em São Paulo. Os Subterranean Tropicalia Projects precederam as Cosmococas e os Parangoplays, roteiros de performances para serem executadas pelos participadores. As

\footnotetext{
${ }^{128}$ Carta de Hélio Oiticica a Augusto de Campos, 16/10/1971. Agradeço a Gonzalo Aguilar pela indicação dessa carta e a Augusto de Campos que autorizou sua publicação em Fios Soltos: a Arte de Hélio Oiticica, op. cit.

${ }^{129}$ CAGE, John. op.cit. p. 133. Em tradução livre da autora: "todas as alguma-coisas no mundo começam a sentir suas por-inteirezas quando alguma coisa acontece que as lembram de nada"

${ }^{130}$ Esse trecho é do texto "Experimental Music", também citado por Oiticica em um de seus cadernos.

CAGE, op.cit., p. 7
} 
três séries de trabalhos da fase novaiorquina unem ambientes projetados - como Oiticica já havia feito com Éden e Tropicália na década anterior -- a instruções para os participadores: "notations", partitura para quem toca seus instrumentos de escala arquitetônica. Oiticica nesse início da década de 1970 está lendo textos de John Cage e anota em um diário de 1973:

pensando em tudo o q há de magnífico neste livro [Silence, de John Cage] penso também em como a música é pra ele e deve ser assim q deve advir o futuro-já! música poema como algo utilizável como instrumento de um todo-performance q se estende como PERFORMANCE $\underline{\text { in }}$ progress e não como meia dúzia de bluffs e demonstração de meio-talento numa 'casa de espetáculo' porque há a necessidade q CAGE mesmo urge e q até hoje não veio a cumprir de q quando não se espera nada mais que NADA TUDO passa a nos DAR: DAR algo q é indiferente a algo (significante) ou q possua 'role' 'valor': DAR o q queremos NOS DAR: NADA ----- ${ }^{131}$

Subterranean Tropicalia Projects são "situações para serem vividas"132, "autoperformances" 133 criadas por labirintos de penetráveis. PN16 seria um labirinto de corredores de paredes pretas que levariam a três salas: na primeira sala, a parede oposta à entrada é fortemente iluminada, ofuscando a visão de quem entra e formando sombras nas paredes escuras, que balançam à medida em que o caminhante prossegue; na segunda sala, o chão é de metal e a iluminação vêm do teto. $O$ chão reflete a luz e ecoa os passos dos caminhantes; na terceira sala, microfones ficam pendurados do teto, e as pessoas devem falar sobre a palavra "nada". PN16 cita também a poesia concreta:

a intenção é confrontar uma palavra específica em um nível de dicionário: NADA, ou a ausência de toda significação, o 'word-type', um conceito linguístico - citando décio pignatari e Luis Angelo Pinto (Invenção, no. 4, ano 3, dez. 1964, São Paulo - texto: crítica, criação, informação - pag. 21): 'word-type' é uma abstração, um conceito linguístico, é a palavra num 'estágio de dicionário', independente de qualquer situação - outra referência que vale fazer aqui seria a descoberta da palavra NADA na fotografia da fachada de um prédio em Washington DC, pelo poeta Augusto de Campos, em seu livro Equivocábulos (edições invenção, são paulo, 1970)

\footnotetext{
${ }^{131}$ OITICICA, Hélio. ntbk 2/73, p. 84

${ }^{132}$ Hélio Oiticica, op.cit., p. 143

${ }^{133}$ Ibid., p. 150
} 
(...) a evocação do 'word'type' NADA deve ser liberada de qualquer correlação com conceitos metafísicos ou tentativas de interpretação. ${ }^{134}$

Várias obras de Oiticica relacionadas aos irmãos Campos remetem ao branco ${ }^{135} . \mathrm{O}$ parangolé P30 capa 23 “m'way ke” foi reproduzido em um cartão postal que Oiticica enviou a Haroldo de Campos ${ }^{136}$. M'way ke é cinza e azul, como um "céu do céu" que o poeta associou ao branco de Maliévitch em "Asa Delta para o Êxtase"137. O parangolé P31 capa 24 é uma faixa de Moebius para ser segurada ao redor do corpo, branca por fora e laranja por dentro e está reproduzido em cartão postal que Oiticica enviou a Augusto de Campos. ${ }^{138}$

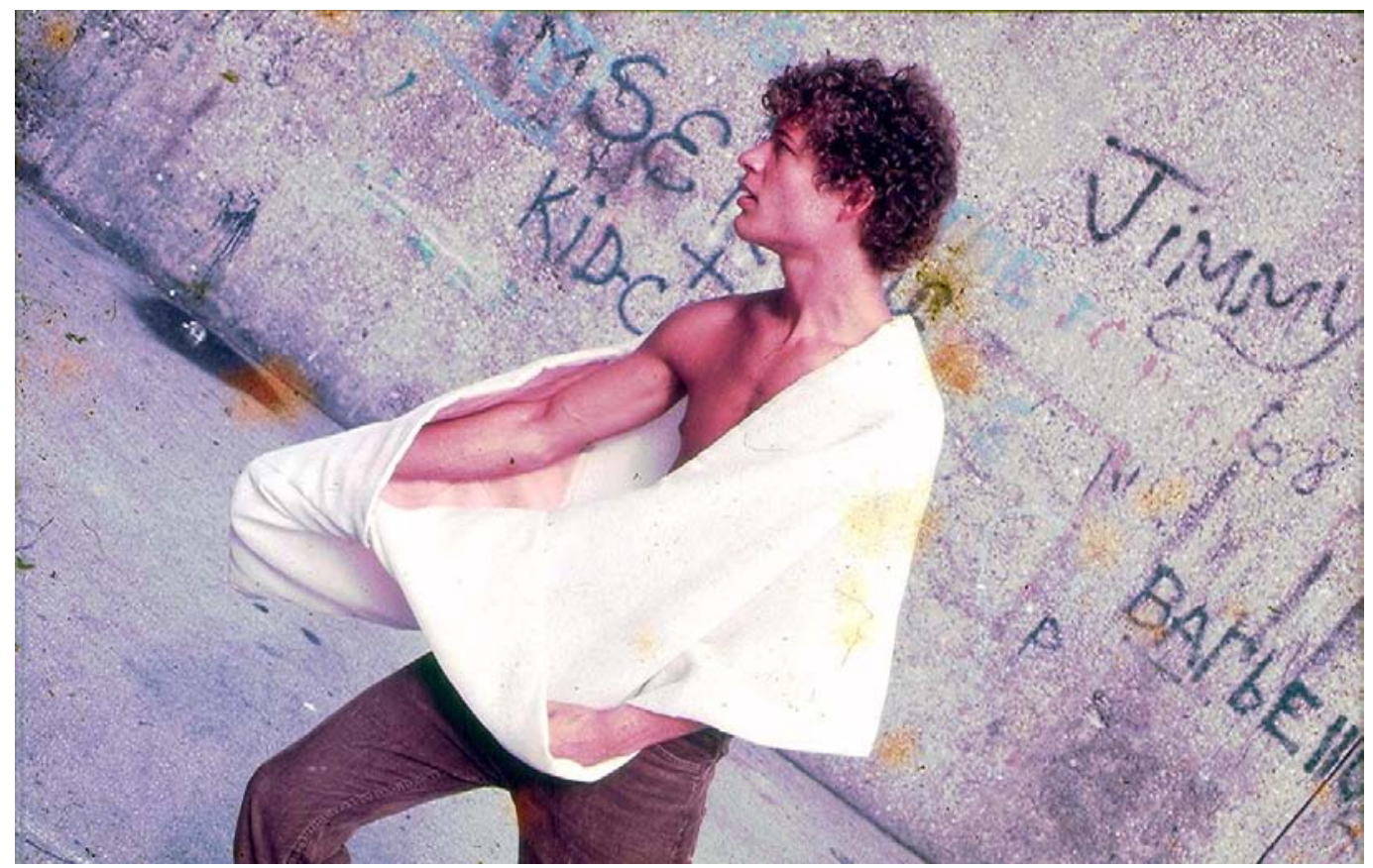

Jeff vestindo Parangolé P31 capa 24. AHO 2124.72-p3

\footnotetext{
${ }^{134}$ Ibid., p. 154 (texto originalmente escrito em inglês, aqui citado em tradução da autora)

${ }^{135}$ cf. AGUILAR, Gonzalo, "Na Selva Branca: o Diálogo velado entre Hélio Oiticica e Augusto e Haroldo de Campos". op. cit.

${ }^{136}$ No verso do cartão Oiticica escreveu a dedicatória "Para Haroldo hagorômico, em homenagem, 3.9.72" conforme citado pelo poeta em CAMPOS, Haroldo de. Hagoromo de Zeami: o charme sutil. São Paulo: Estação Liberdade, 1993.

${ }^{137}$ CAMPOS, Haroldo de. "Asa Delta para o Êxtase". Hélio Oiticica, op.cit., p. 217-21.

${ }^{138}$ O verso do cartão postal diz "nyk 30 dez 1972. Augusto, Aqui vai um parangolé newyorkiano para lhe desejar melhor dos 73." Agradeço a Gonzalo Aguilar por me ceder um fac-simile digital desse cartão.
} 
Aguilar nota a especificidade destes parangolés que, diferentemente das capas da década de 1960, não exigem a dança, mas um "repouso dinâmico." ${ }^{39}$ O branco do papel, as sílabas omitidas em poemas concretos, sugerem para Oiticica o quanto o branco pode cobrir e descobrir, como o movimento da cocaína por cima dos rostos dos Blockexperiments in Cosmococas. Ao comentar "dias dias dias", de Augusto de Campos, é nos brancos que Oiticica se detém:

os rastros [em Cosmococas] sempre aparecem e desaparem não só no desenho como depois de cafungados (...) eu acho que o branco... bom uma coisa louca que eu descobri quando tem aquele "a" e depois "mor" é "amor", mas é "morte", mas aí você nunca... a gente fica assim imediatamente completando "mor", com morte mas a sílaba "T-E" na realidade se esconde debaixo do branco, o branco tá cobrindo ela é a meu ver a gente tem muita dessa coisa assim do pó aparecer e desaparecer nesse... quer dizer é tudo como se fosse assim uma espécie de exercício assim da ambivalência da pessoa... sei lá aliás o branco dessa coisa tem uma coisa assim de neve um pouco de neve também já é cocaína "snow" essa coisa assim de cobrir (...) chão, la neige étternelle $d u$ sol, chão de neve eterna (...) ${ }^{140}$

\section{"Chão de neve eterna" é a tradução proposta por Oiticica para a última frase do primeiro verso de Rimbaud em Villes (I) ${ }^{141}$, de Illuminations: \\ L'acropole officielle outre les conceptions de la barbarie moderne les plus colossales. Impossible d'exprimer le jour mat produit par le ciel immuablement gris, l'éclat impérial des bâtisses, et la neige éternelle du sol.}

\footnotetext{
${ }^{139}$ Aguilar escreve: “O parangolé P30 capa 23 " $m$ 'way ke”, dedicado a Haroldo de Campos, é absolutamente branco e transparente, diferentemente de quase todas as outras capas que giram ao redor dos amarelos e laranjas. Além disso, enquanto estes últimos exigem os corpos em movimento, " $m$ 'way ke" se caracteriza pelo que Denis Riout denominou, a propósito de Maliévitch, "repouso dinâmico". O parangolé P31 capa 24 que Hélio envia a Augusto de Campos em um cartão postal, também usa só o branco e consiste em uma faixa de Moebius ao redor do corpo de Jeff (o modelo) exigindo o movimento de suas mãos (como no dedicado a Haroldo, a remissão à escritura está na importância dada às mãos)." Ibid.

${ }^{140}$ Comentário de Oiticica sobre o poema "dias dias dias" de Augusto de Campos, em fita gravada em 19 de março de 1974, conforme citado por AGUILAR, Gonzalo, op. Cit. Há uma transcrição datilografada dessa fita no Programa HO, com lacunas que omitem a frase de Rimbaud que fecha o excerto acima. (PHO 0503/74)

${ }^{141}$ Oiticica cita várias vezes esse verso de Villes(I) em seus escritos de 1973. No rascunho do bloco Cosmococas de Newyorkaises, porém, indica que incluiria a primeira estrofe de Veillées, que é o poema seguinte a Villes(I) no livro Illuminations. Outras anotações de Oiticica no diário 2 de 1973 citam Veillées . No mesmo diário, Oiticica desenvolve alguns parágrafos sobre a "vigília", um estado entre o sono e o estar acordado. Vigília é também o título de uma proposição que Oiticica enviaria a Silviano Santiago para ser feita no Rio de Janeiro. cf. OITICICA, Hélio. ntbk 2/73 pg. 105-108.
} 
A mudança na tradução (de "neve eterna do chão" para "chão de neve eterna") ocorre segundo Oiticica "porque o original e o que quero como tradução acima referemse (e dão algo) a algo planetário: UMA/ou A/ CONDIÇÃO DA TERRA (CHÃO E PLANETA): e jamais 'neve q cai sobre a terra' como se a uma descrição e/ou rememoração de paisagem urbana" ${ }^{142}$ Rimbaud é, assim como Duchamp, associado à pausa $^{143}$, ao recolhimento. O chão de neve eterna é o branco que precisa ser lido não como ausência, mas pausa que encobre e revela, existência simultânea de duas intensidades, como amor e morte, arte e vida. Esse trecho é ainda associado livremente por Oiticica ao "sol do meio-dia" de Nietzsche ${ }^{144}$. Oiticica quer que "sol" no poema de Rimbaud seja "sol” e não "solo". Por fim, mantem-no como "chão" na tradução.

\author{
CHÃO DE NEVE ETERNA \\ mas eu quero q SOL seja SOL \\ (SILVIANO juntou SOL-SOLO q \\ também tem a ver com isso: \\ e porisso me pergunto: \\ q fusões-frissons se passam \\ nessas pensantes poéticas \\ de SOL \\ SOLO \\ CHÃO \\ NEVE
}

\footnotetext{
142 OITICICA, Hélio. "Riscado etc continuação", 02/12/1974. AHO 0180.74

${ }^{143}$ Confira na seção anterior texto de Oiticica sobre o intermezzo de Duchamp, que recusou a produção serializada de obras e recolheu-se para jogar xadrez ("HO NYK sept. 1, 71: anotações para serem traduzidas para inglês: para uma próxima publicação" 01/09/1971,op.cit.). No mesmo texto, Oiticica cita a "deserção de Rimbaud da poesia" e sugere a simultaneidade ao explicar a pausa de Rimbaud como "necessidade não-linear". Oiticica defende que a crítica precisa entender que existem "evoluções simultâneas 'não-lineares'".

${ }^{144}$ A primeira parte de Assim Falou Zarathustra termina com "Da virtude que dá". Zarathustra quer que seus discípulos o deixem prosseguir só em sua caminhada. Os discípulos oferecem a ele um cajado que tem no alto um sol dourado cercado por uma serpente. Zaratustra discursa a seus discípulos e menciona o grande meio-dia, quando o homem "posiciona-se a meio caminho entre a besta e o além-do-homem" e o sol de seu conhecimento que "estará no alto do meio-dia para ele." cf. NIETZSCHE, Friedrich. The Portable Nietzsche (ed.) Walter Kaufmann. New York: Penguin Books, 1976, p. 190. O meio-dia é também o horário em que os dados lançados afirmativamente retornam, para um novo lance de dados. O lance de dados será discutido na próxima seção. Sobre o meio-dia como horário do retorno dos dados, cf. DELEUZE, Gilles. "The Dicethrow" in . Nietzsche and Philosophy. New York: Columbia University Press, 2002, p. 25-27.
} 
SOLEIL

ETERNO

NEIGE ÉTERNELLE DU SOL

!!! não pergunto!

respondo e digo:)

dig'o o q quero

quero NEVE-COCA

SOL NIETZSCHE MEIO-DIA

CHÃO-RIMBAUD

SOL-NEVE

BRANCO SOBRE O BRANCO

SOL MALEVITCH

o brilho q diamanta o PÓ caído NEVE

de BRANCO-LUZ q inunda do CHÃO

ao SOL tod'os recantos vistos e não-vistos

visíveis invisíveis palpando impalpabilidade

o q eu quero lhe dar é algo assim

irrepetível como o

SONHO DE SOL DE NIETZSCHE

o

BRANCO-MALEVITCH

o

CHÃO DE RIMBAUD

a

NEVE-LUZ

$$
\text { q indissolúvel não dilui }
$$

e q divina MANTOS como o q HAROLDO

DE CAMPOS me abriu do

ANJO HAGOROMO

japonês q funde

LUZ

no

CÉU DO CÉU

q é algo q vibra

NIETZSCHE

RIMBAUD 
otimismo

$$
\text { SONHADO-INTOXICADO }{ }^{145}
$$

"Neve indissolúvel", como escreve Oiticica no texto reproduzido acima, o chão de neve eterna talvez seja a própria invenção, o eterno novo. Eterno, mas não estático pois a invenção é entendida aqui como matéria dotada de "duração", que se transforma continuamente, movimento que percebemos apenas através de alguns estados discretos (por exemplo, Maliévitch, Rimbaud, Haroldo de Campos e Nietzsche, para ficarmos apenas com os estados que Oiticica cita acima) mas que são estágios de um processo contínuo de escoamento de um estado a outro, constituindo um fluir, uma duração: “progresso contínuo do passado que rói o porvir e que incha ao avançar"146.

"Nossa duração é irreversível", escreve Bergson:

Nossa personalidade, que se edifica a cada instante a partir da experiência acumulada, muda incessantemente. Ao mudar, impede que um estado, ainda que idêntico a si mesmo na superfície, se repita algum dia em profundidade. É por isso que nossa duração é irreversível. Não poderíamos reviver uma sua parcela, pois seria preciso começar por apagar a lembrança de tudo aquilo que se seguiu. Poderíamos, a rigor, riscar essa lembrança de nossa inteligência, mas não de nossa vontade.

Ao conferir à arte-invenção uma "duração", Oiticica vibra em otimismo: a evolução inventiva do novo é indissolúvel como a neve eterna. A invenção do novo é irreversível, escreve Oiticica:

os BÓLIDES são importantes não porque sejam caixa-OBJETO mas porque fazem parte desse furacão estrutural --> dessa emergência irreversível do NOVO (...) HOJE no q faço e no correr daquilo a q chamo de meu processo de desmitificação (não confundir desmitificação com desmistificação) q vem comandando esses anos 70, a posição desses BÓLIDES (e consequentemente do assunto do OBJETO) se põe tão claro quanto o sol do meio dia num dia glorioso de sol: considero-os como parte fundamental no q hoje vejo como PRELÚDIO AO

\footnotetext{
${ }^{145}$ OITICICA, Hélio. “Carta para Waly Salomão”, 23/01/1974. AHO 318.73-p20 a p37. Publicado na revista Pólem, Editora Lidador, 1974 (cf.AHO 896.74). cf. também comentário de Silviano Santiago em $O$ Globo, 3/11/1974 em AHO 897.74.

${ }^{146}$ BERGSON, A Evolução Criativa, op. Cit, p. 5
} 
NOVO: tudo o q veio antes desse processo de desmitificação não passa de PRELÚDIO àquilo q há de vir e q já começa a surgir a partir desse ano na minha 'obra': ao q antes chamei de OVO há de seguir o NOVO - e já era tempo! ${ }^{147}$

Oiticica percebe-se como um dos estados de um processo contínuo de mudança e também como um estado seguinte, auto-definido-se como transformação. Um "ser arte" (ou "ser anti-arte"148), é grávido ${ }^{149}$ daquilo que é novo, irreversível, irrepetível. Mas que retorna sempre. Misturar arte e vida talvez seja, para Oiticica, entender a arte como algo que possui a "duração" daquilo que é vida.

${ }^{147}$ OITICICA, Hélio. "Texto feito a pedido de Daisy Peccinini como contribuição para uma publicação sobre o objeto na arte brasileira nos ano 60". PHO 101.77.

${ }^{148}$ Oiticica cita em 1/09/1971 o artigo de Décio Pignatari "Marco zero de Andrade" (O Estado de São Paulo, 24/10/1964, Suplemento literário, op.cit.,p. 5): “o 'projeto geral' de que fala décio é a definição mais feliz do conceito [de anti-arte], aliás usado como "ser anti-arte", e, aí, oposto às divagações pseudo-críticas, de saber se "anti-arte" existe como tal ou se passa a ser "arte", etc., comuns na parafernália bestialógica de criticos (oides), etc. -- anti-arte é pois ser anti-arte (ali, é claro, décio se refere a oswald de andrade), um problema que se refere mais ao sujeito do que ao objeto)." No texto de Décio Pignatari, lê-se:"Esse ser antiarte está intimamente vinculado ao estabelecimento de uma linguagem, de um projeto geral - ou de um roteiro, para utilizar um termo oswaldiano. Envolve um problema de comunicação com a massa, por via imediata e direta. Em oposição portanto ao sistema vigente de administração da cultura (complexo editorial, ensino, museus, exposições, concertos, etc.) que é de natureza classe-consumista, impondo os ditames de seus interesses às fontes de criação artística."

${ }_{149}$ Reservamos o espaço de uma nota de rodapé para sugerir uma aproximação entre o percurso de Oiticica com a cor e a obra de Anish Kapoor. A obra de Kapoor "When I am Pregnant", de 1992, é uma intrigante parede branca "grávida", imperceptível se vista de frente, prestes a parir se vista de lado. "Ascension", de 2003, é a cor branca corporificada em fumaça numa coluna de vapor que, na exposição no Centro Cultural Banco do Brasil no Rio de Janeiro (julho a setembro de 2006), saía do chão até alcançar o topo do domo central do prédio. O video "Wounds and Absent Objects", de 1998, trabalha a transformação contínua e quase imperceptível de uma cor em outra: "Não me interesso pela composição. Quero encontrar condições absolutas. Se eu faço algo vermelho, não se trata de vermelho em relação a outra coisa. Trata-se de vermelho, do mesmo modo que, quando você põe a mão na água, ela é molhada. Então quero o vermelho tão vermelho quanto a água é molhada." (KAPOOR, Anish, Ascension. Centro Cultural Banco do Brasil, 2006-2007). Tradução da autora a partir do texto em inglês do catálogo. 


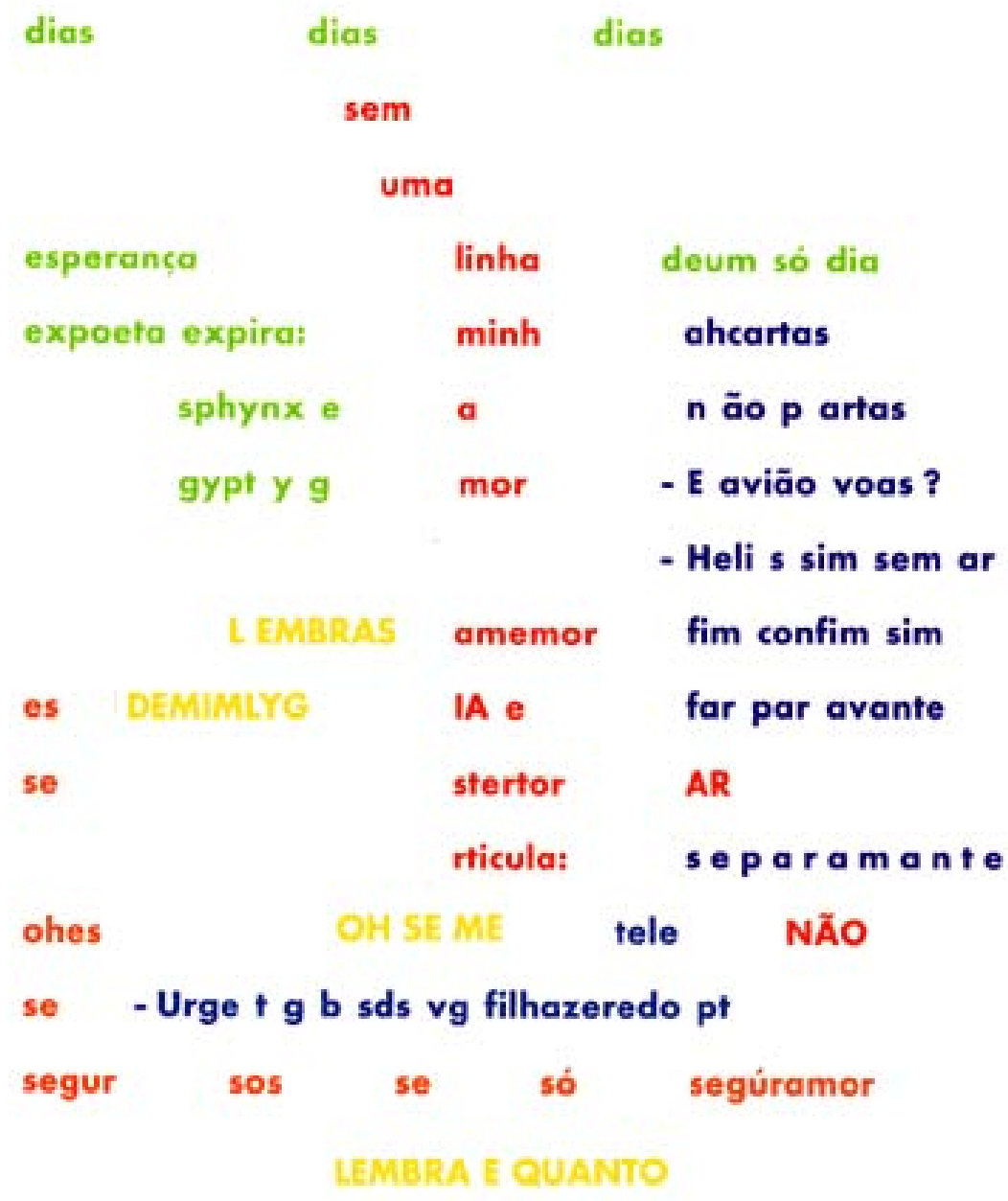

Augusto de Campos, “dias dias dias", Poetamenos, 1953 


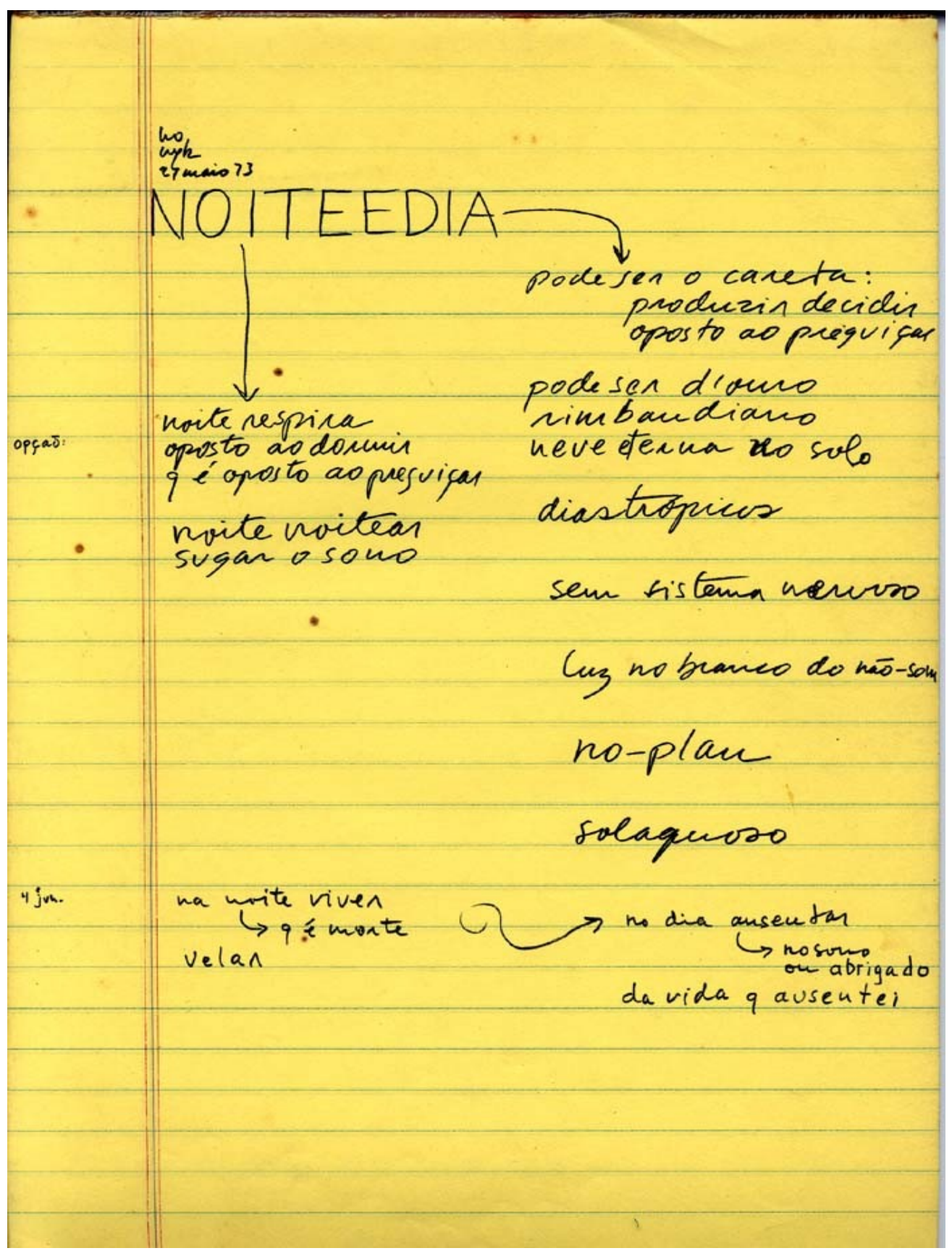

Texto de Hélio Oiticica. AHO 267.73-p1 


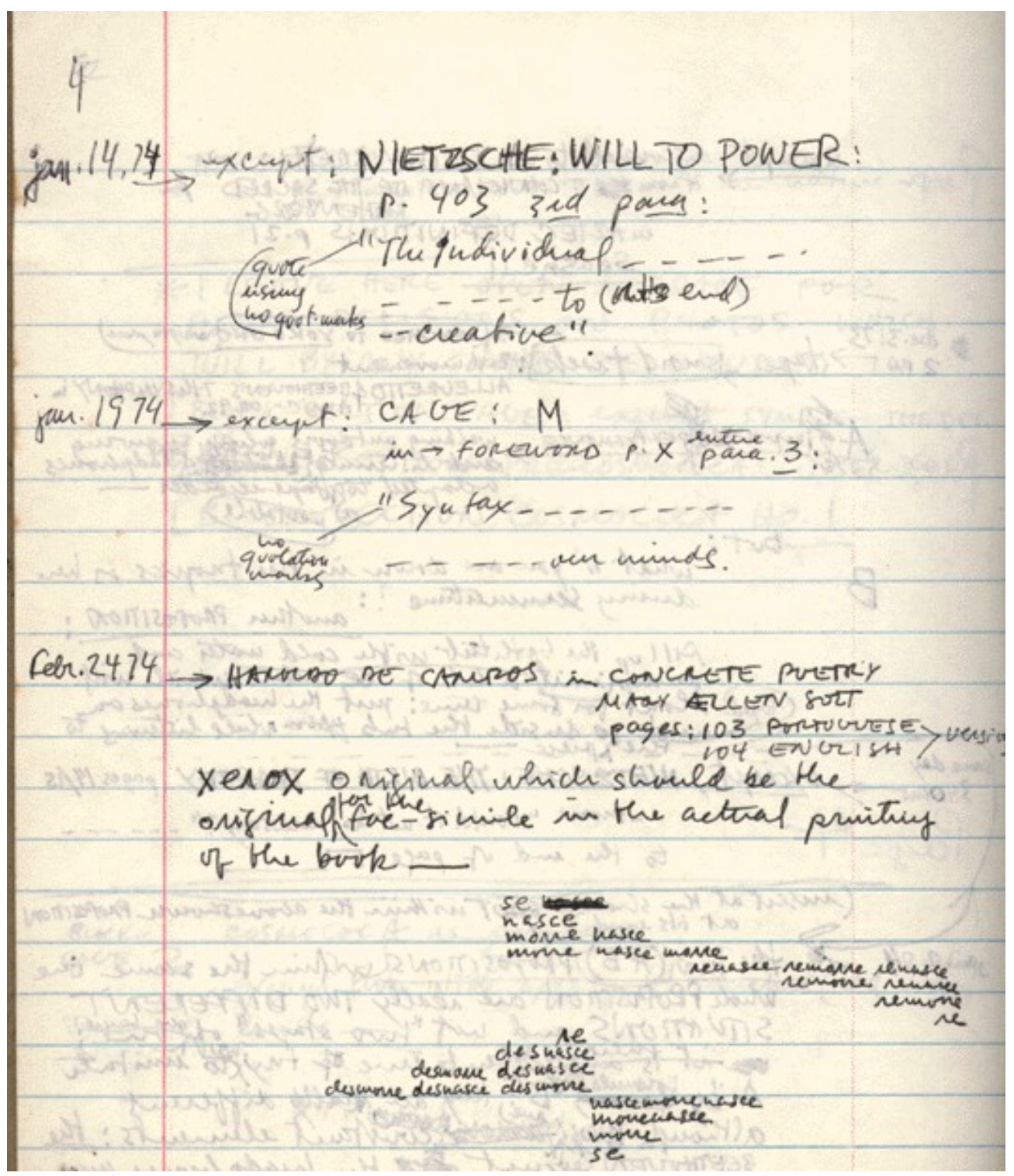

Rascunho do bloco Cosmococa de Newyorkaises, incluindo trechos de Nietzsche, Cage e o poema Se de Haroldo de Campos. Este bloco incluiria ainda excertos de Rimbaud, uma homenagem a Freud no poemaproposição "ÜberCoca" de Oiticica, um trecho da letra da canção gravada pelos Rolling Stones "Sympathy for the Devil", algumas páginas de Experiment in Totality de Sybil Moholy-Nagy (incluindo a fotografia da acrópole reproduzida naquele livro), citações de "Technicians of the sacred" (compilação de poesias tribais organizada por Jerome Rothenberg), estrofes de "L'ombilic des Limbes" de Antonin Artaud e um trecho escrito por um amigo italiano de Oiticica, Franco Pace-Palitti. ${ }^{150}$ AHO 311.73-p4

${ }^{150} \mathrm{cf}$. PHO 0311/73 


\subsection{Construção e acaso}

Uma das aparições mais reveladoras da palavra "síntese" nos textos de Oiticica é a caracterização do que foi "Tropicália", em texto de 1969: "Tropicália não é um movimento artístico mas a constatação de uma síntese onde objetivos gerais se encontram: cinema, teatro, artes-plásticas, música popular, porque as barreiras entre essas divisões formais tendem a se dissolver em algo maior". ${ }^{151}$ É a síntese como algo que soma e supera as partes. A princípio, Oiticica pretendia abordar o problema da imagem com a obra Tropicália: imagem do Brasil, a imagem que as elites desejariam esquecer e substituir por elementos das culturas norte-americanas e européias, e o poder devorador da imagem televisiva ligada no centro de um labirinto.

Em sua primeira montagem, na exposição Nova Objetividade Brasileira no MAM-RJ em 1967, Tropicália incluía intervenções de outros artistas: poemas de Roberta Oiticica e um balcão com jornais desenhados de Antônio Manuel, que estava não apenas "próxima" da obra de Oiticica mas constituía "parte" de Tropicália. ${ }^{152}$

Tropicália não tinha bordas e, como conclui Oiticica retrospectivamente, passou a abranger não só imagens e obras de outros artistas, mas todo um programa cultural. A "síntese", dirá Oiticica, foi feita pelos músicos:

Síntese Tropicália: O conceito de Tropicália, a princípio relacionado a uma idéia teórica pura, se espalhou de repente para fora do meu campo específico, através de um evento que quero descrever aqui: a música popular de Caetano Veloso e Gilberto Gil (compositores e cantores), Torquato Neto e Capinam (letras), Tomzé (compositor e cantor), Gal Costa (cantora). De repente Caetano Veloso tornou possível e provocou a síntese: uma composição estranha e inesperada dele ainda não tinha nome; alguém nomeou-a de Tropicália, o nome e conceito que caíam melhor para ela. ${ }^{153}$

\footnotetext{
${ }^{151}$ OITICICA, Hélio., "Tropicália: the image problem surpassed by that of a SYNTHESIS”, maio/1969 (originalmente escrito em inglês, trad. da autora). AHO 0350.69

${ }^{152}$ Depoimento de Antônio Manuel à autora. Em 1967, Oiticica encontrou o jovem artista fazendo intervenções sobre notícias de jornal em uma mesa no restaurante do MAM -RJ e convidou-o a fazer parte de Tropicália na mostra que abriria uma semana depois. Para um depoimento de Oiticica sobre as razões que o levaram a incorporar o balcão de flan de Antônio Manuel a Tropicália, cf. OITICICA, Hélio.

"Anotações para ANTÔNIO MANUEL", 22/02/1974. AHO 303.73-p25.

${ }^{153}$ OITICICA, Hélio. "Tropicália, the New Image". AHO 0535.69. trad. da autora.
} 
O Tropicalismo foi absorvido com "voracidade burguesa" 154 como uma moda ou movimento artístico. Nos textos de Oiticica, porém, a expansão de Tropicália para além do problema da imagem é coerente com uma estratégia recorrente nas proposições do artista: repetindo a manobra da "síntese" abordada no tópico anterior, Oiticica passa a considerar Tropicália como o corpo concreto de um programa cultural que estava sendo conduzido paralelamente por artistas plásticos, músicos, teatrólogos, poetas e cineastas mesmo antes da música de Caetano encontrar os penetráveis: unir inconformismo estético a inconformismo político-social. ${ }^{155}$

Tropicália é junção de blocos - penetráveis, areia, brita, araras, plantas, poemas e jornais -- como tantas outras proposições e labirintos. Num dos primeiros projetos para labirintos, o Projeto Cães de Caça, Oiticica usa a "sucessão de elementos" em um jardim "que não se trata de um jardim habitual como se está acostumado a entender, com utilidade pura e simples de jardim". Trata-se de um labirinto de 3 saídas e "vão-se sucedendo os elementos de ordem estética que o compõem, que são: O 'Poema enterrado' de Ferreira Gullar, o 'Teatro integral' de Reinaldo Jardim e cinco penetráveis" de Hélio Oiticica: "o indivíduo aqui se refugiaria, assim como quem entra num museu, para vivências de ordem estética, como se fosse algo mágico, capaz de levá-lo a outro plano que não o do cotiano." 156

Nos bólides, a manipulação de partes não está mais nem em sucessão nem em justaposição: surge a "incorporação" de um objeto a uma idéia, formando um "transobjeto", operação que supera a justaposição segundo o artista.

aí a cuba de vidro que contém a cor poderia ser chamada de objeto pré-moldado, visto já estar pronto de antemão. O que faço ao transformá-lo numa obra não é a simples "lirificação" do objeto, ou situá-lo fora do cotidiano, mas incorporá-lo a uma idéia estética, fazê-lo parte da gênese da obra, tomando ele assim um caráter transcendental, visto participar de uma idéia universal sem perder a sua estrutura anterior. Daí a designação de "transobjeto" adequada à experiência (...) não há na obra terminada uma 'justaposição virtual' dos elementos, mas que ao

${ }^{154}$ OITICICA, Hélio. Aspiro ao Grande Labirinto, op.cit, p. 109

${ }^{155}$ cf. FAVARETTO, Celso. "Inconformismo social, inconformismo estético, Hélio Oiticica", op.cit e "Tropicália: the explosion of the obvious" in Tropicalia: a revolution in Brazilian Culture. BASUALDO, Carlos (ed.) São Paulo: Cosac\&Naif, 2005.

${ }^{156}$ OITICICA, Hélio. "Projeto Cães de Caça e Pintura Nuclear", s.d. Esse texto foi escrito em forma de entrevista mas não há informação sobre quem seria o entrevistador. Talvez fosse o próprio Oiticica. AHO 0024.61. 
procurar a cuba e sua estrutura implícita, já se havia dado a identificação da estrutura da mesma com a da obra, não se sabendo depois onde começa uma e onde termina a outra.

No texto "Bases Fundamentais para a definição do Parangolé", de 1964, Oiticica explica seu processo de escolha dos objetos esparsos que compõem suas proposições:

Se bem que eu faça uso de objetos pré-fabricados nas obras (p. ex., cubas de vidro), não procuro a poética transposta desses objetos como fins para essa mesma transposição, mas os uso como elementos que só interessam como um todo, que é a obra total. [...] A cuba de vidro contém a cor em pó, p. ex., mas para a percepção da obra o que interessa é o fenômeno total que, em primeiro lugar, se dá diretamente e não em "partes". Não é o “objeto" cuba e o "objeto" pigmento-cor, mas a "obra” que já não é o objeto no que possuía de conhecido, mas uma relação que torna o que era conhecido num novo conhecimento[... $]^{157}$

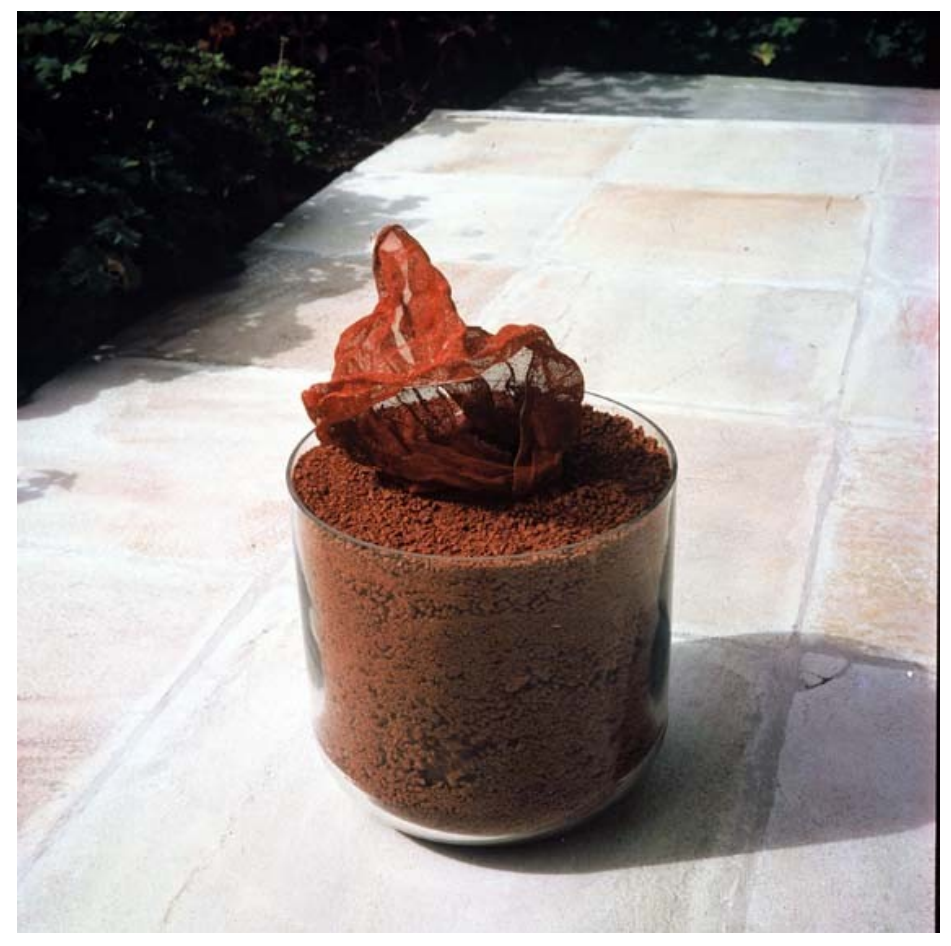

Bólide vidro 4, Terra, 1964. AHO 2222.sd-p1

${ }^{157}$ OITICICA, Hélio. "Bases fundamentais para uma definição do 'Parangolé'”, , novembro de 1964, em . Aspiro ao Grande Labirinto. op.cit., p. 65-66 
As partes que constroem um bólide não se prestam, portanto, a uma "análise", separação das partes, mas à construção de um todo, à fusão/síntese dessas partes em um novo conhecimento: adjunção. É certo que as partes não desaparecem. Mas o organismo que passam a constituir é elemento novo no mundo. Aqui vale citar Bergson:

Toda obra humana que contém uma parte de invenção, todo ato voluntário que contém uma parte de liberdade, todo movimento de um organismo que manifesta espontaneidade traz algo de novo para o mundo. Temos aí, é verdade, apenas criações de forma. Como poderiam ser outra coisa? Não somos a própria corrente vital; somos apenas essa corrente já carregada de matéria, isto é, de partes congeladas de sua substância que ela arrasta ao longo de seu percurso. $\mathrm{Na}$ composição de uma obra genial assim como em uma simples decisão livre, por mais que tensionemos no mais alto grau a mola de nossa atividade e criemos assim o que nenhuma junção pura e simples de materiais teria podido oferecer (que justaposição de curvas conhecidas equivaleria algum dia ao traço de lápis de um grande artista?), nem por isso deixa de haver aqui elementos que preexistem e sobrevivem à sua organização (...) Consideremos todas as letras do alfabeto que entram na composição de tudo o que algum dia foi escrito: não concebemos que outras letras surjam e venham se acrescentar a estas para fazer um novo poema. Mas que o poeta crie o poema e que o pensamento humano dele se enriqueça, nós o compreendemos muito bem (...) Assim, que aumente o número de átomos que compõem o universo material em um dado momento, isso choca nossos hábitos de espírito, isto contradiz nossa experiência. Mas que uma realidade de uma ordem inteiramente diferente e que se distingue do átomo como o pensamento do poeta das letras do alfabeto cresça por adições bruscas, isto não é inadmissível; e o avesso de cada adição bem que poderia ser um mundo, o que nos representamos, aliás simbolicamente, como uma justaposição de átomo (...) o universo não está feito, mas faz-se incessantemente. Cresce indefinidamente, sem dúvida, pela adjunção de mundos novos. ${ }^{158}$

A referência de Bergson a letras que formam poemas abre-nos a possibilidade de pensar as junções feitas por Oiticica como construção de uma linguagem usando como palavras as "ordens de experiências": "Daí eu passei a fazer o que eu chamava de Manifestações Ambientais, a juntar essas diversas ordens de experiências: Penetráveis, Núcleos, Bólides e Parangolés..."159 As fotografias do Whitechapel Experiment ilustram

${ }^{158}$ BERGSON, Henri. A Evolução Criadora, op.cit., p. 260-262

${ }^{159}$ OITICICA, Hélio. Entrevista a Ivan Cardoso, 1979, op.cit., p. 69, cotejado com o áudio da entrevista (na publicação lê-se "o que chamavam de Manifestações Ambientais". No áudio, Oiticica diz "o que eu chamava de Manifestações Ambientais") 
esse convívio de várias ordens a serem combinadas por cada participador. Não se trata de uma exposição com várias obras de um artista, mas de uma única obra: a Whitechapel Experience, que adjuntou Éden e Tropicália, por sua vez construídos com penetráveis, ninhos, bólides, parangolés.

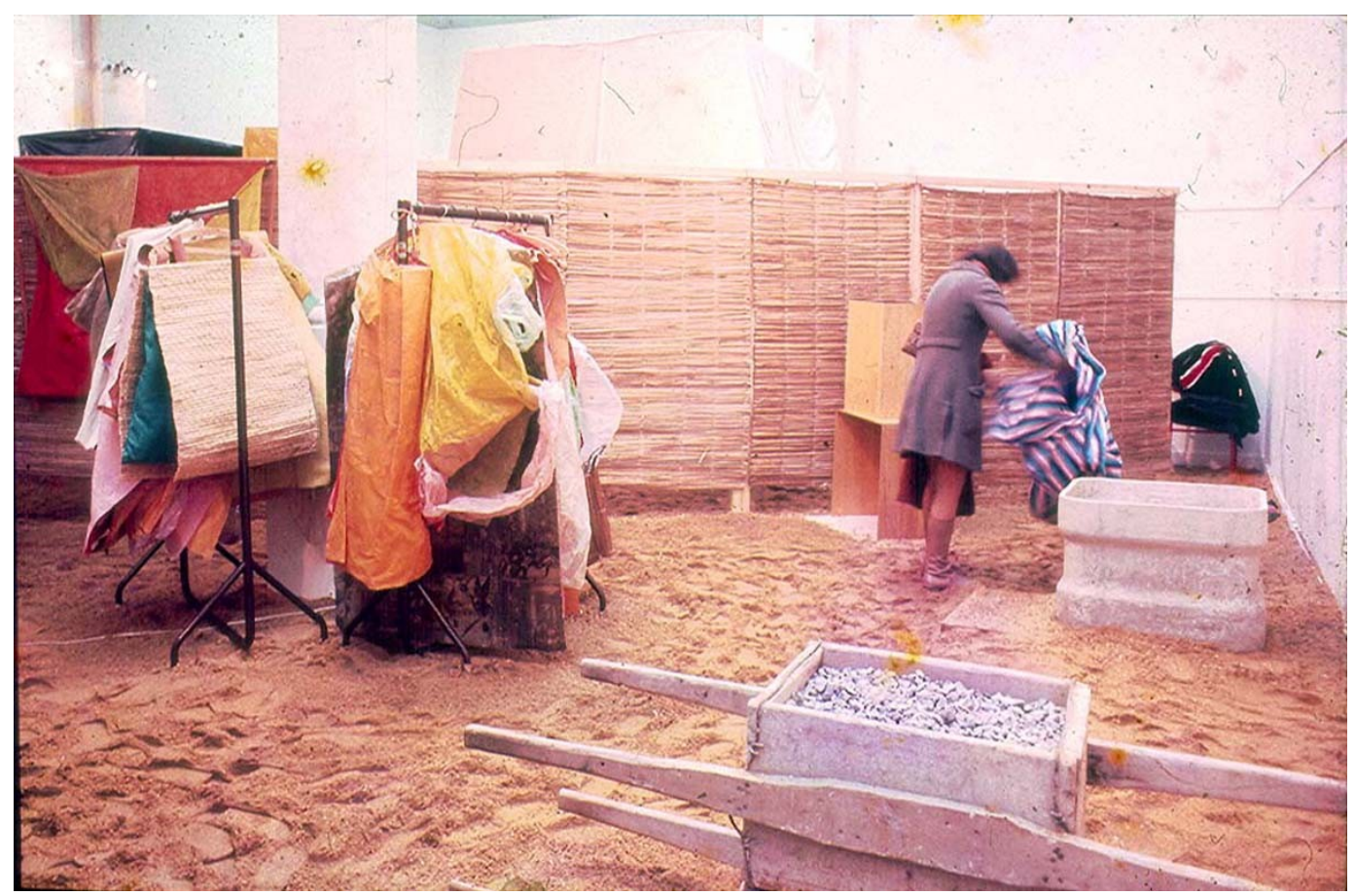

Whitechapel Experience, Londres, 1969. AHO 1999.69-p.24.

É na maneira como os fragmentos são misturados, selecionados, que surge o novo conhecimento. O texto Experimentar o Experimental, de 1972, enfatiza o trabalho do artista como dependente de elementos pré-existentes: "YOKO ONO: Quanto à minha arte tenho a dizer: artistas não são criativos. Que mais se desejaria criar? Tudo já está aqui (...) Criar não é tarefa do artista. Sua tarefa é a de mudar o valor das coisas." 160

Criação remete a gênese, a um deus criador, que do nada cria algo bem acabado. A invenção, ao contrário, baseia-se em outras invenções e gera outras invenções, reordena e desestabiliza os signos; não cria pois tudo já está aqui. "Inventar: processo in

${ }^{160}$ OITICICA, Hélio. "Experimentar o Experimental”, 22/03/1972. op.cit. 
progress q não se resume na edificação de OBRA mas no lançamento de mundos q se simultaneiam. Simultaneidade em vez de mediação."161

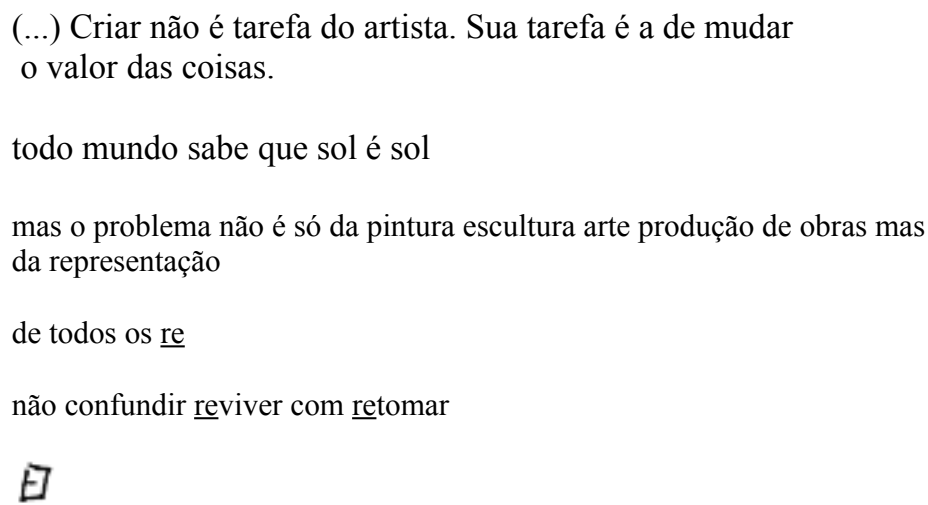

O experimental retoma, mas não revive pois reviver implica na ressurreição de algo morto, o "revival de terceira categoria". Retomar é a necessária e irreversível combinação vitoriosa do lance de dados, do NOVO que retorna no glorioso sol do meiodia. O sol - que aparece no ideograma chinês do excerto acima - não morre para renascer. O sol retorna.

Criar um objeto ou proposição fechada não muda comportamento e, pior ainda, está sujeito a diluição, a ser ingerido como obra acabada e contribuir apenas para uma diarréia rala ${ }^{163}$. Invenções abertas e contínuas, ao contrário, funcionam como retroalimentação da trama.

\section{Acaso}

As partes que Oiticica junta para construir novos mundos são "procuradas" ou “achadas ao acaso"? Da década de 1960 para a década de 1970 ocorre uma mudança na concepção de "acaso" nos textos de Oiticica. Em 1963, Oiticica recusava a palavra

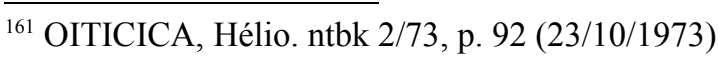

${ }^{162}$ OITICICA, Hélio. "Experimentar o Experimental”, 22/03/1972. op.cit.

${ }^{163}$ A "diarréia", termo empregado por Oiticica no texto "Brazil Diarréia",op.cit., de 1970, remete novamente à diluição a à propriedade da invenção de resistir a uma absorção rala, sem efeitos nutritivos no organismo. 
"acaso" e empenhava-se na "busca obstinada" pelos objetos que realizariam a idéia intuída a priori. Os fragmentos achados por Oiticica para integrar o todo não são aleatórios, mas selecionados, como descrito no texto "Bólides", de outubro de 1963:

Nada mais infeliz poderia ser dito do que a palavra "acaso", como se houvesse eu "achado ao acaso" um objeto, a cuba, e daí criado uma obra; não! A obstinada procura "daquele" objeto já indicava a identificação a priori de uma idéia com a forma objetiva que foi "achada" depois, não ao "acaso" ou na "multiplicidade das coisas" onde foi escolhido, mas "visada" sem indecisão no mundo dos objetos, não como "um deles que me fala à vontade criativa" mas como o "único possível à realização da idéia criativa intuída a priori” $(. . .)^{164}$

Mas na década de 1970, o acaso é mais bem-vindo em suas obras, atrelado ao "nãoprograma" e à "busca da falta de conseqüência"165, expressões que Oiticica utiliza ao descrever a proposição "Delirium Ambulatorium" em texto de 1979. Falamos aqui de um acaso, é claro, seletivo, ou melhor, um encontro feliz com um fragmento. Em 1974, Oiticica reconhece a importância do jogo e da "chance operation": "COSMOCOCA supera a época de isolar o MÍTICO porque se abre/ e abre/ ao/o/ JOGO: à chance operation" $" 166$.

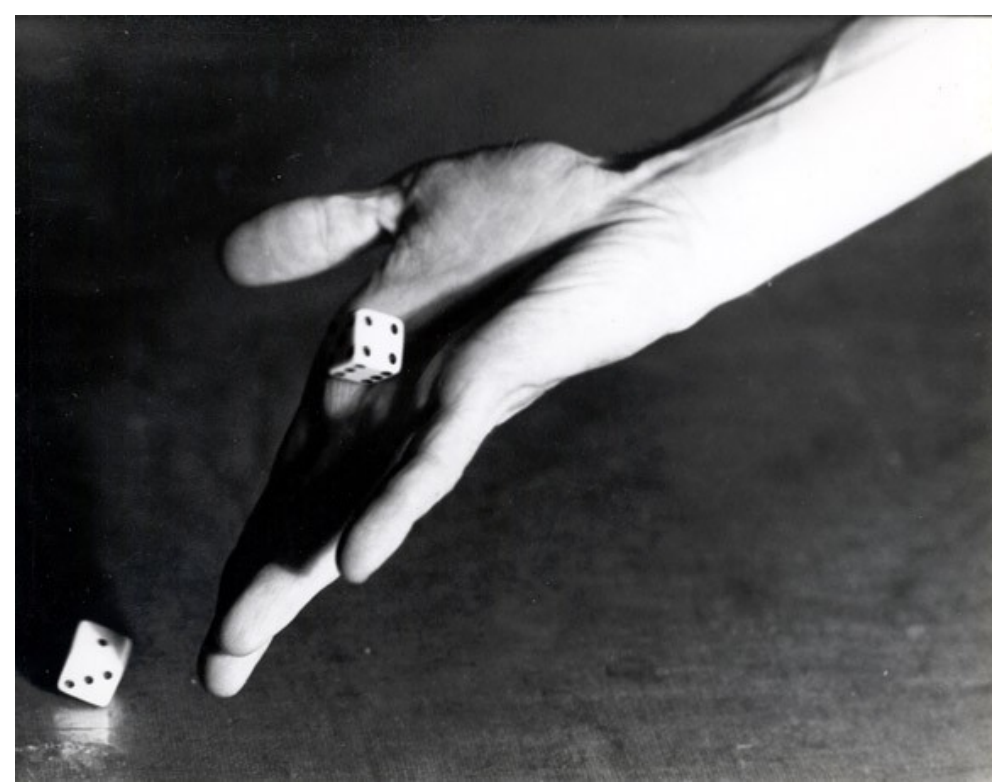

Fotografia do arquivo de Hélio Oiticica. DICE THROW. foto: Thomas Valentin. PHO 427/73a

\footnotetext{
${ }^{164}$ OITICICA, Hélio. Aspiro ao Grande Labirinto, op.cit. p. 63

${ }^{165}$ OITICICA, Hélio. "Memorando Caju”, 1979. AHO 114.79

${ }^{166}$ OITICICA, Hélio. "Vendo um filme de Hitchcock, 'Under Capricorn'”, 31/03/1974. PHO 0318/74 - 15/24
} 
Com efeito, Oiticica planejava incluir em Newyorkaises uma ilustração do "jogo de dados", no bloco subterranean TROPICALIA Projects. No verso da foto DICE THROW (lance de dados) de Thomas Valentin, Oiticica anotou: "to be printed side by side to DIE in Newyorkaises; subterranean TROPICALIA PROJECTS block-section”. A foto the SILVER DIE também reproduz um dado (die), já pousado na mesa. As instruções escritas nessa foto ("reference as repertory on the repertory page") referem-se a uma coleção de materiais que Oiticica chamava de "repertório", que incluiria tanto o "material bruto" colecionado quanto as idéias para utilizá-lo: "they are open-images just 'presented', not directly meant as a 'representation' of anything 'significant', but as poetically-given repertorial images." 167

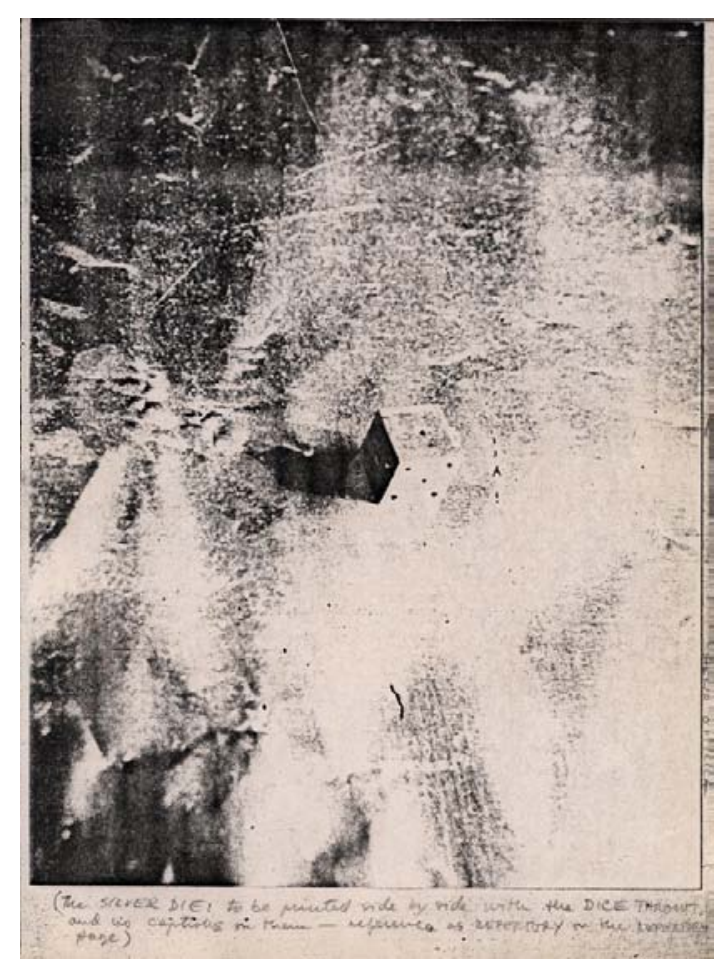

Página do arquivo de Hélio Oiticica com a anotação: "The SILVER DIE: to be printed side by side with the DICE THROW and no captions on them - reference as repertory on the repertory page" 168 .

\footnotetext{
${ }^{167}$ OITICICA, Hélio. Sem título, 26/09/1971, citado no catálogo Hélio Oiticica, op.cit., p. 148. "elas são imagens-abertas, simplesmente "apresentadas", não diretamente com finalidade de "representação" ou qualquer coisa "significativa", mas como imagens repertoriais poeticamente-dadas". (trad. da autora) ${ }^{168}$ O dado de prata: a ser impresso ao lado do LANCE DE DADOS e sem legendas neles - referência como repertório na página de repertório.
} 
No filme Agripina é Roma-Manhattan ${ }^{169}$, Mario Montez e Antonio Dias jogam dados. O roteiro desse filme em super-8 de Oiticica inspira-se em "O Inferno de Wall Street", uma das partes do poema "épico sem trama" (plotless epic) ${ }^{170}$ de Sousândrade $O$ Guesa Errante ${ }^{171}$. Em carta para Carlos Vergara, Oiticica descreve a cena do "Oráculo": july 23 - O ORÁCULO - MARIO MONTEZ e ANTONIO DIAS jogam dados no jogo de dados divinatório jogo na praça d'onde ${ }^{172}$ se avistam torres edifícios maggritteanos em céus rarenublados indiferença ensolarada da praça e o foco sagrado não-sagrado do jogo de dados ${ }^{173}$

A carta continua com o roteiro de outras cenas de Agripina é Roma-Manhattan, trechos do texto Parangolé-síntese, referências a Gertrude Stein e Jimi Hendrix e, acompanhando a referência sousândrica ao inferno, termina com o verso de "Sympathy for the devil", dos Rolling Stones: "But what's puzzling you is the nature of my game."174

\footnotetext{
${ }^{169}$ O filme em Super-8 Agripina é Roma-Manhattan, de Hélio Oiticica, com 16min. 27seg. , faz parte da coleção de filmes de artistas plásticos do Centro Georges Pompidou.

${ }^{170}$ cf. CAMPOS, Augusto de e CAMPOS, Haroldo de. ReVisão Sousândrade. Rio de Janerio: Nova Fronteira, 1982, p. 40.

${ }^{171}$ Os irmãos Campos informam que guesa quer dizer também errante, sem lar. O guesa era uma criança cuja vida marcava ciclos de 15 anos do povo muísca, da Colômbia. Dos 10 aos 15 anos, essa criança, roubada dos pais e criada num templo, peregrinava numa rota mítica. Aos 15 anos, a peregrinação se encerrava com sua morte sacrificial, inaugurando um novo ciclo com uma nova criança (ibid., p. 40). A primeira edição deste livro dos irmãos Campos é de 1964. "Agripina é Roma-Manhattan" é uma frase que ocorre no parágrafo 129 do poema "O Guesa Errante" de Sousândrade. Para uma análise desse poema como umas das várias intersecções entre as obras de Hélio Oiticica e dos irmãos Augusto e Haroldo de Campos, cf. AGUILAR, Gonzalo. "Hélio Oiticica, Haroldo y Augusto de Campos: el diálogo velado - la aspiración a lo blanco" (ainda não publicado) ou, do mesmo autor, "Na Selva Branca: o diálogo velado de Hélio Oiticica e Augusto e Haroldo de Campos" in Fios Soltos: a Arte de Hélio Oiticica. BRAGA, Paula (org.) op.cit.

172 Aqui há uma referência a Sousândrade na contração de "de onde" para "d'onde". Seria interessante buscar referências ao poeta maranhense em outros escritos de Oiticica. A aliteração do título de seu famoso texto de 1968 "A Trama da Terra que Treme" pode bem ser uma referência à estrofe 42 de "O Inferno de Wall Street" (em $O$ Guesa Errante): --Napoleão! Grand'Catarina!/ Treme a terra à cris-sensação! /Demóstenes! Grande/ Alexandre!/ Woman rights, hipódromo e pão!

${ }^{173}$ OITICICA, Hélio. "LEORK”, 1972. AHO 0212.72. cf. também AHO 0262.72

174 "O que está te confundindo é a natureza do meu jogo". Um dos blocos de Newyorkaises, inciado em 1974, tem o título de "Ultimately Mick Jagger". Em um vídeo disponível na Internet gravado no Rock and Roll Circus em 1968, Mick Jagger parece ter saído de uma fotografia da série Neyrótika (1973), com batom vermelho nos lábios e sombra branca nos olhos enquanto canta "Sympathy for the Devil" para uma platéia fantasiada, que movimenta capas amarelas e laranjas. cf.
} http://www.youtube.com/watch?v=waFOyhezIPA, acessado em dezembro/2006. 


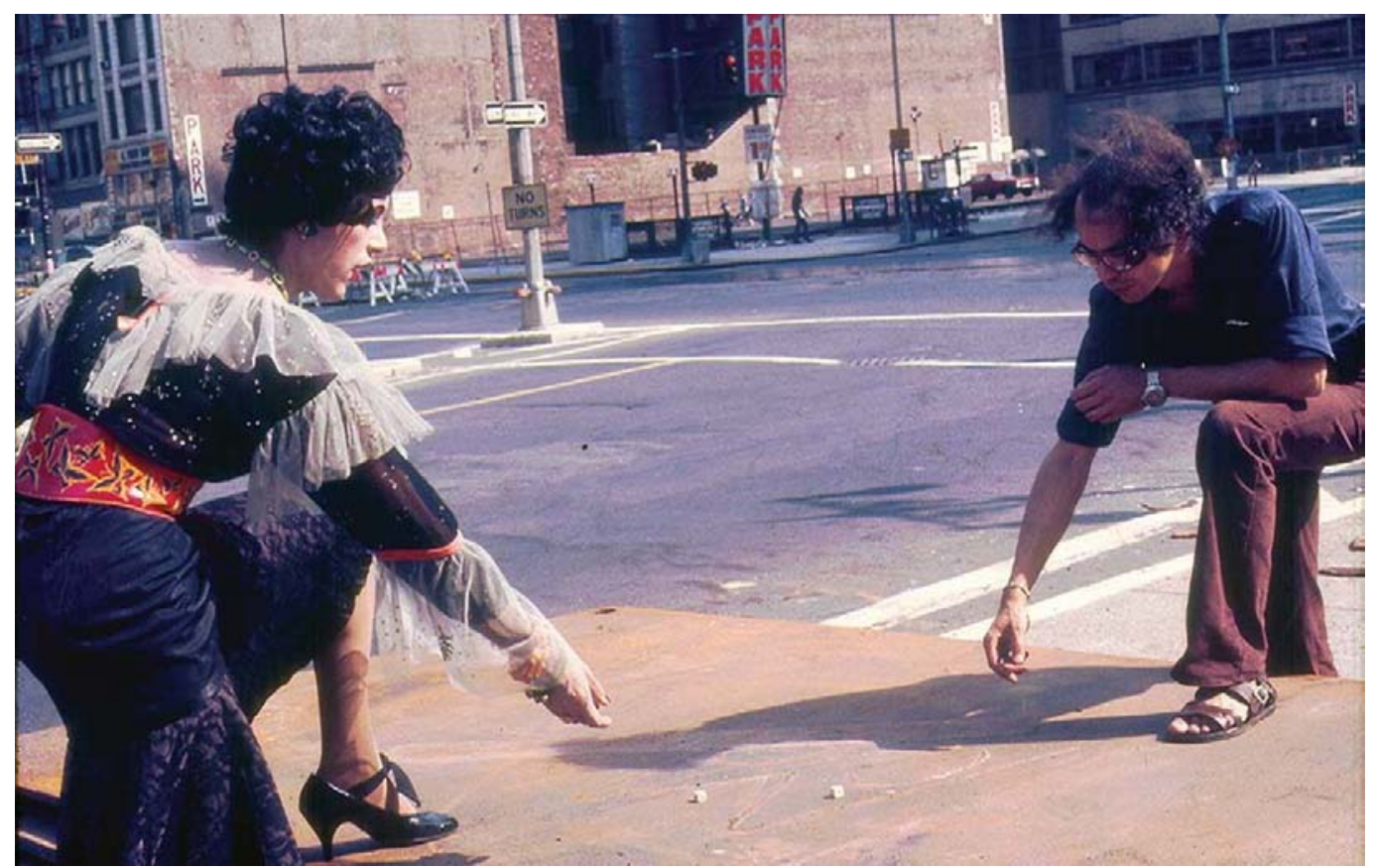

Cena do filme de Oiticica Agripina é Roma-Manhattan, de 1972. AHO 2105.72-p4.

O acaso aparece também nas Cosmococas: "acaso como jogo aparece 1- na hora de tirar as fotografias 2- na ordem em que elas são colocadas na caixa pelo laboratório de revelação 3 - na ordem em que são colocadas no carrossel." ${ }^{175} \mathrm{O}$ rosto fotografado em cada slide também é obra do acaso: "quero dizer o porque das escolhas e inclusões em COSMOCOCAS: primeiramente, não há nenhum porque: as escolhas não são escolhidas, mas vieram até mim"176

Não basta achar o objeto pronto. Oiticica não pára no ready-made: inova-o lançando o "ready-constructible". É preciso achar os blocos, e então juntá-los.

O READY-CONSTRUCTIBLE

substitui-herda o conceito

de READY-MADE

INOVA-O ${ }^{177}$

\footnotetext{
${ }^{175}$ OITICICA, Hélio. ntbk 2/73, p. 59 (originalmente em inglês, trad. da autora)

${ }^{176}$ Ibid., p. 98 (originalmente em inglês, trad. da autora)

${ }^{177}$ OITICICA, Hélio. “Anotações sobre o Ready-constructible”, 20/08/1978. AHO 088.78.
} 
Oiticica caracteriza como "indireta e longínqua" sua relação com Duchamp em texto de $1978,{ }^{178}$ afirmação significativa já que o artista brasileiro nunca se recusou a reconhecer parentescos bastante próximos com outros artistas e pensadores: "Sou filho de Nietzsche e enteado de Artaud"179, disse ele, por exemplo, em 1978. Essa intrigante distância que Oiticica estabelece em relação à Duchamp talvez se justifique, como já notado por Favaretto, pelo forte vínculo que Duchamp estabelece sarcasticamente com a história da arte. A Oiticica interessam os inventores que se embasam menos na história da arte ou da filosofia e mais nas estruturas primordiais de criação. Ora, já vimos o quanto Duchamp é importante para Oiticica articular a pausa e a crítica ao sistema da arte. O que Oiticica parece recusar é o Duchamp historiografado como o inventor do ready-made.

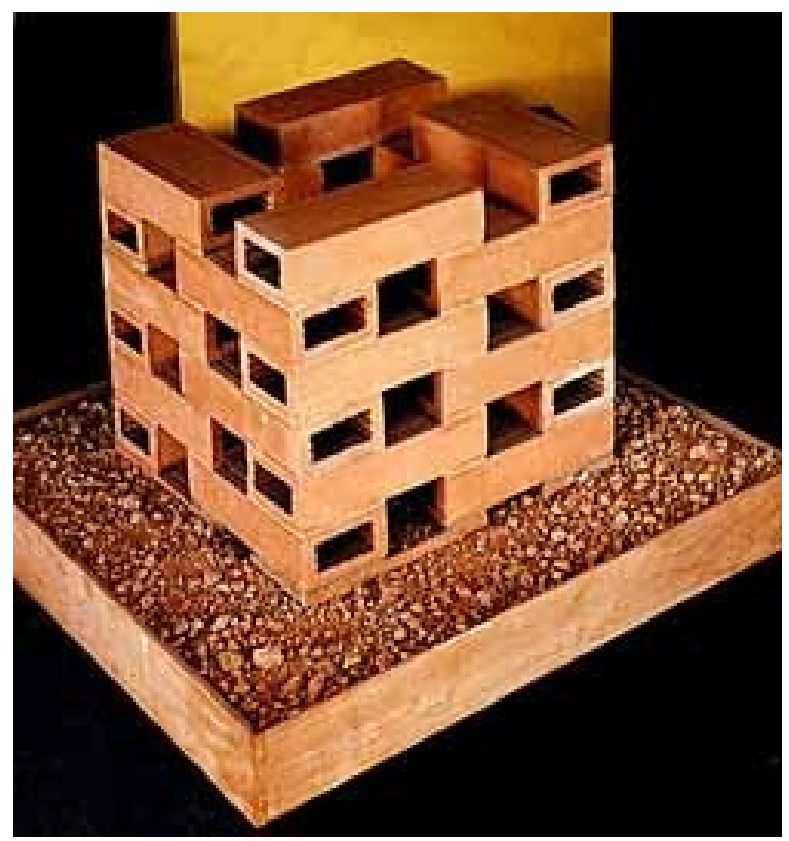

Hélio Oiticica. Ready-constructible no. 1, 1978

O Ready-constructible no. 1 foi associado por Oiticica ao Brutalismo, estilo arquitetônico de construções de Le Corbusier da década de 1940 retomado nos anos 1950

\footnotetext{
${ }^{178}$ Para uma discussão sobre as afinidades e diferenças das posições de Oiticica e Duchamp em relação ao objet-trouvé, cf. FAVARETTO, Celso, "Por que Oiticica" in Por que Duchamp (org.) BOUSSO, Daniela (org.) São Paulo : Paço das Artes / Itaú Cultural, 1999, p. 80-89.

179 "Um Mito Vadio", entrevista de Hélio Oiticica a Jary Cardoso. Folhetim, 5/11/1978. AHO 944.78.
} 
na Inglaterra pelos arquitetos Alison e Peter Smithson, que promoveram o que ficou conhecido como Novo Brutalismo. O Brutalismo privilegiava a fidelidade aos materiais usados, por exemplo, mantendo visíveis depois do término da construção marcas de madeira nas paredes ou tetos. Repetição de blocos articulados também caracteriza as construções brutalistas, geralmente feitas de concreto ou tijolos aparentes. É interessante notar que o prédio em Marselha, projetado por Le Corbusier, Unité d'Habitation (194752), possui uma "morfologia celular que automaticamente expressa uma aglomeração de habitações privadas" ${ }^{\prime 180}$. Essa descrição aplica-se também à estrutura dos Ninhos de Oiticica, como vemos na fotografia feitas em Sussex.

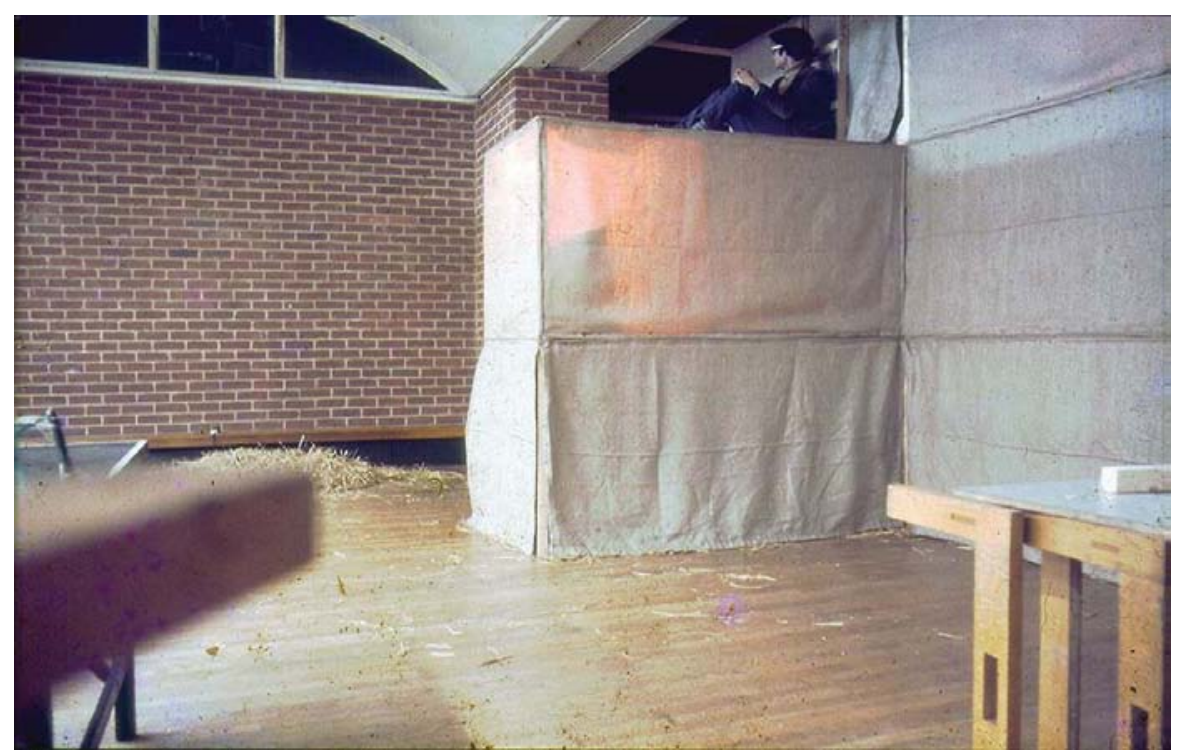

Hélio Oiticica. Ninhos, Universidade de Sussex, 1969. AHO 2008.69.

Os blocos do Ready-constructible no. 1 incluem não só os tijolos mas também o barro no qual a estrutura foi erguida: a mesma matéria transformada. Oiticica descreve a construção dessa estrutura como tendo seguido a "topo-grafo-logia" dos tijolos ao assentá-los: “o não-determinado precisamente estruturado"181.

\footnotetext{
${ }^{180}$ FRAMPTON, Kenneth. Modern Architecture: a critical history. New York: Thames and Hudson, 1992, p. 226

${ }^{181}$ OITICICA, Hélio. “Anotações sobre o Ready-constructible”, op. Cit.
} 


\author{
Este READY-CONSTRUCTIBLE n. 1 \\ é o exercício meu extremo entre \\ o READY e o inacabado \\ estrutura \\ determinada sem começo-meio-fim (...) \\ O READY-CONSTRUCTIBLE n. 1 \\ q funda espaço \\ se ergue num terreno \\ (mini-maxi terreno já q \\ é algo sem escala) \\ barrento como se fora algo \\ moldado todo da mesma massa: como \\ se fora (e o é) algo indeterminado \\ não se sabendo onde começa \\ (ou por onde se começa) \\ o sólido e o arenoso \\ e quem sabe o q \\ poderia vir a ser \\ lama-líquida!: 182
}

\title{
A transformabilidade da terra aparece também na operação contra-bólide
}

\section{"Devolver a Terra à Terra" ${ }^{183}$, de 1980.}

Nesta operação contra-bólido pego uma forma de madeira de $80 \mathrm{~cm}$ x $80 \mathrm{~cm}$ x $10 \mathrm{~cm}$ e preencho-a de terra preta trazida de outro local. Mas em vez de ser esta terra colocada num container é ela colocada nesta cerca sem fundo: o fundo é a própria terra da localidade onde foi colocada a forma: a forma é então retirada, deixando então TERRA SOBRE TERRA q ali fica: o CONTRA-

${ }^{182}$ OITICICA, Hélio, "Anotações sobre o Ready-constructible", op.cit. (grifos conforme o original)

${ }^{183}$ No manuscrito preparatório para "Devolver a Terra à Terra" (PHO 123.78), de 01/01/1980, Oiticica usa o título "Devolver a Terra à Terra" e diz que em inglês deveria constar como "To Return Earth unto Earth." O Cahier \#2 do Witte de With Center for Contemporary Art informa que este texto foi escrito originalmente em inglês (cf. OITICICA, Hélio. "To Return Earth unto the Earth". Witte de With Cahiers \#2, ed. Richard Verlag. Roterdam: Witte de With Center for Contemporary Art, 1994.), o que nos parece impreciso dada a existência do texto preparatório escrito à mão em português. A informação sobre o texto ter sido escrito originalmente em inglês é repetida no catálogo bilíngue da exposição retrospectiva de 1992 (cf. Hélio Oiticica, op. cit., p. 202). Interessa-nos aqui a tradução proposta por Oiticica: to return não é somente "retornar" num percurso, mas "devolver."A idéia de repetição imbuída na operação contra-bólido ("pode ser repetido quando houver ocasião ou necessidade") nos sugere que a idéia do retorno em Oiticica abrange também "repetição". O retorno é assim uma volta cíclica, uma devolução e uma repetição: a repetição devolve um elemento ao ciclo do eterno retorno. 
BÓLIDE passa a ser então em vez de obra uma espécie de programa-obra in progress q pode ser repetido quando houver ocasião-necessidade para tal: o CONTRA-BÓLIDE revelaria a cada repetição desse programa-obra in progress o caráter de concreção de obra-gênese q comandou a invenção-descoberta do BÓLIDE nos idos de 63: porisso era o BÓLIDE uma nova ordem de obra e não um simples objeto ou escultura! $!^{184}$

"Concreção de obra-gênese" pode ser entendido como concreção de um processo de invenção: mudar as coisas de lugar, trazer terra de um lugar para outro: "peguei terra em Jacarepaguá, e em vez de encerrar a terra numa cuba, peguei a terra e levei lá para o Aterro de Lixo do Caju." 185

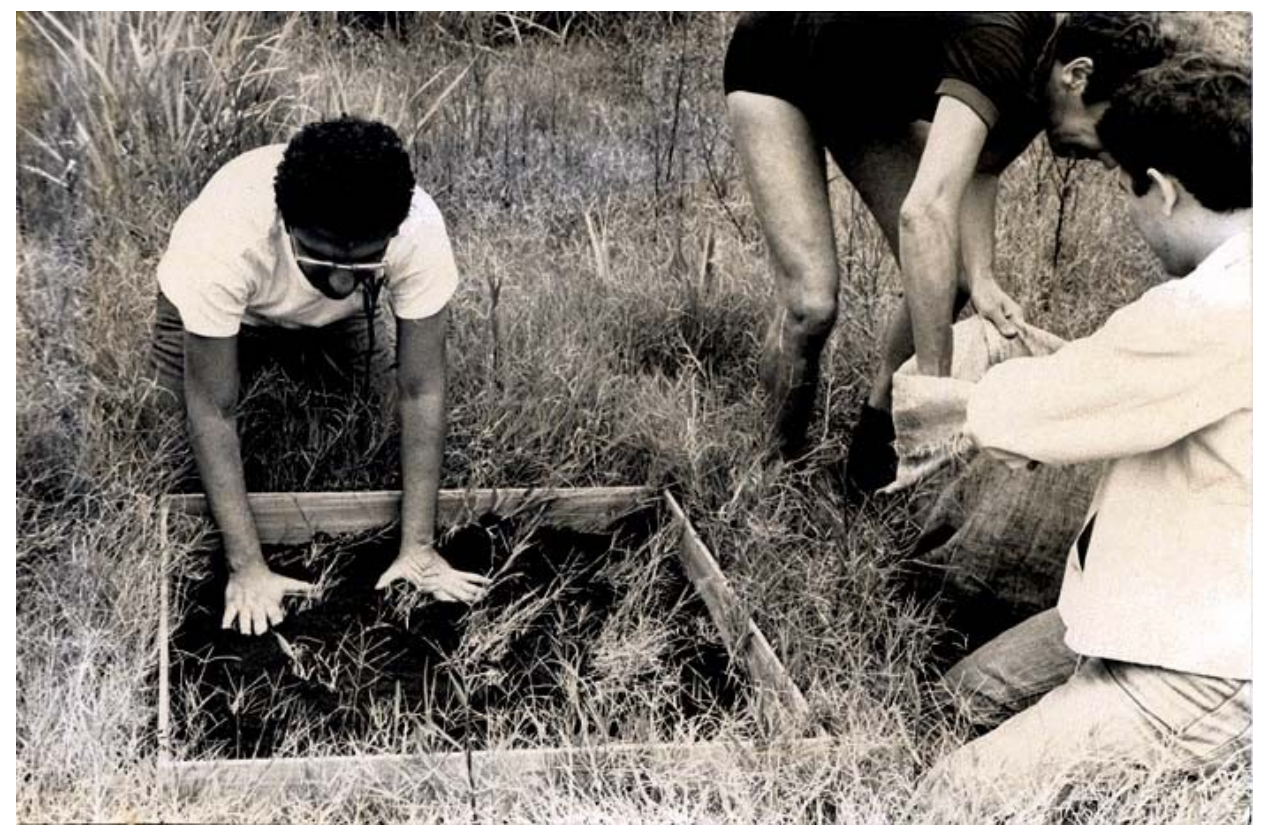

Hélio Oiticica. Devolver a Terra à Terra, acontecimento poético Kleemania. Aterro do Caju, Rio de Janeiro, 18/12/1979. AHO 0522.79

Com a repetição ("pode ser repetido quando houver ocasião-necessidade para tal"), Oiticica corrobora a idéia da gênese como derivada de um retorno (ou devolução dos dados), em oposição à gênese criacionista. A terra não é mais colocada em um recipiente fechado, mas oferecida de volta à terra através de uma cerca sem fundo.

\footnotetext{
${ }^{184}$ OITICICA, Hélio. "Devolver a terra à Terra". PHO e AHO 123.78

${ }^{185}$ OITICICA, Hélio in "A última entrevista de Hélio Oiticica", Jorge Guinle Filho, Interview, abril/1980.
} 
Em textos sobre Hélio Oiticica esse contra-bólide revela sua multiplicidade: há quem o relacione com o repúdio ao objeto e instituições de $\operatorname{arte}^{186}$, ao quadrado preto de Melevitch $^{187}$, às favelas do $\mathrm{Rio}^{188}$, ao participador como artista trágico ${ }^{189}$. Obra aberta, Devolver a Terra à Terra é repetido nos textos dos comentadores de Oiticica quando há ocasião e diferentes necessidades.

Como ação, Devolver a Terra à Terra foi repetido em cada cidade por onde a exposição retrospectiva de 1992-93 passou (Roterdã, Paris, Barcelona, Lisboa e Mineápolis) e Guy Brett comentou a ambivalência das fotografias daquelas repetições claramente executadas por funcionários da mostra e em locais próximos às instituições que receberam a exposição: registros de um enterro ou de um momento de ressurreição? "O contra bólide foi sempre qualquer um dos dois, ou ambos, um enterro e uma ressurreição"190 comentou. "Enterro do objeto, e seu renascimento como ato", escreveu Brett em outro texto sobre o contra-bólide ${ }^{191}$. Num momento contemplativo, o contrabólide fixado nas fotografias é um enterro. Mas no momento seguinte torna-se uma das obras de Oiticica mais abertas a conseqüências: renasce, remorre, renasce ${ }^{192}$.

Lançar os dados confiando em obter o duplo seis: Oiticica trabalha com o acaso como destino ${ }^{193}$, que encontrou no Nietzsche de Deleuze. "Caiu-me nas mãos o livro de

${ }^{186}$ BRETT, Guy. "A Paradox of Containment" in Witte de With Cahiers \#2, ed. Richard Verlag. Roterdam: Witte de With Center for Contemporary Art, 1994.

${ }^{187}$ BRAGA, Paula. "Hélio Oiticica: Nietzsche's Übermensch in the Brazilian Slums". Tese de mestrado defendida na University of Illinois at Urbana-Champaign em 2001.

188 JACQUES, Paola Berenstein. Estética da Ginga: a arquitetura das favelas através da obra de Hélio

Oiticica. Rio de Janeiro: Casa da Palavra, 2001, p. 130

${ }^{189}$ LAGNADO, Lisette, Op.Cit., p. 186.

${ }^{190}$ BRETT, “A Paradox of Containment”, op.cit., p. 13.

${ }^{191}$ Hélio Oiticica, op.cit., p. 235

${ }^{192}$ Trecho do poema Se, de Haroldo de Campos, que integraria o bloco Cosmococa em Newyorkaises. Cf. OITICICA, Hélio. "Cosmococa: as drafted and synthetized for inclusion in Newyorkaises”, outubro/1973 a fevereiro/1974. PHO 0311/73. No mesmo bloco de Newyorkaises, Oiticica indica uma passagem de NIETZSCHE, Friedrich. The Will to Power, op.cit., p.403 (fragmento 767) sobre o indivíduo e a interpretação: "the individual is something quite new which creates new things, something absolute; all his acts are entirely his own. Ultimately, the individual derives value of his acts from himself; because he has to interpret in a quite individual way even the words he has inherited. His interpretation of a formula at least is personal, even if he does not create a formula; as an interpreter he is still creative." (O indivíduo é algo bastante novo que cria coisas novas, algo absoluto; todos os seus atos são completamente seus. No fim, o indivíduo deduz os valores de seus atos por si próprio; porque ele tem que interpretar de forma bastante individual até as palavras que herdou. Sua interpretação de uma fórmula é no mínimo pessoal, mesmo se ele não cria a fórmula; como intérprete, ele ainda é criativo.'(trad. da autora)

${ }^{193}$ Não confundir destino com finalidade. Deleuze fala de um destino irracional e não de uma finalidade. O acaso são fragmentos de um destino imune à razão imbuída na finalidade. cf. DELEUZE, Gilles, “The 
DELEUZE sobre NIETZSCHE e só esta semana descobri-li a abordagem do artista trágico q faz"194). No livro Nietzsche e a Filosofia, que Oiticica teve em mãos em 1979, Deleuze afirma que "Nietzsche identifica o acaso com o múltiplo, com os fragmentos, com os membros, com o caos: caos de dados que se chocam e que se lançam. Nietzsche faz do acaso uma afirmação. O reino de Zaratustra é chamado de 'grande acaso'(...) Saber afirmar o acaso é saber jogar (...) Que o universo não possui nenhum objetivo, que não existe qualquer fim a esperar, assim como causas a conhecer, é esta a certeza que convém ter para bem jogar." 195

Zaratustra, lembremos, cozinha o acaso em seu caldeirão, à sua moda, de acordo com sua vontade:

pois bem! Esta é a minha prédica para seus ouvidos: eu sou Zaratustra, o sem-Deus, que fala: "quem é mais sem-Deus do que eu, para que eu me alegre com seu ensinamento? Eu sou Zaratustra, o sem-Deus; onde encontro o meu semelhante? E são meus semelhantes todos aqueles que dão a si próprios sua vontade e se desfazem de toda resignação. Eu sou Zaratustra, o semDeus; e ainda me cozinho todo acaso em minha panela. E somente quando ele está bem cozido eu lhe dou boas-vindas, como minha comida. E em verdade muito acaso veio a mim como senhor: mas mais senhorialmente ainda falou-lhe minha vontade $(\ldots)^{196}$

Fazer do acaso o ingrediente fundamental para uma receita exige atitude inventiva de quem recebe um fragmento e um jogador de dados confiante no acaso, que acredita que seu lance será usado numa mistura conseguinte, mas imprevisível.

O "Memorando Caju", de 1979, onde Oiticica define o Delirium Ambulatorium, termina com a transcrição da definição de trágico dada por Deleuze em Nietzsche e a Filosofia. Trágico é o lance de dados, a valorização do acaso, o sim à vida e à alegria. A

Dicethrow" in _. Nietzsche and Philosophy. New York: Columbia University Press, 2002, p. 25-27. ${ }^{194}$ OITICICA, Hélio. Memorando Caju, 1979, op. cit. Como diz no memorando, Oiticica já conhecia a interpretação que Deleuze fez da obra de Nietzsche desde "a metade da década de 1970" graças a Silviano Santiago. cf. anotação de 7/fev/1975 em OITICICA, Hélio. ntbk2-73, p. 153 e "Carta para Mary e Mario Pedrosa", 28/02/1975. AHO 1411.75

${ }^{195}$ DELEUZE, Gilles. "O Lance de dados" in Nietzsche e a Filosofia. Porto: Rés-Editora, 2001, p. 42-43.

${ }^{196}$ NIETZSCHE, Assim falou Zaratustra, parte III, 'Da virtude que apequena” em Obras incompletas, op.cit. p. 247 
tragédia é um tônico - intoxicante - para a vida ${ }^{197}$. Neste parágrafo, transcrito por Oiticica da edição em francês, lê-se:

\begin{abstract}
A alegre mensagem é o pensamento trágico; porque o trágico não reside nas recriminações do ressentimento, nos conflitos da má consciência, nem nas contradições de uma vontade que se sente culpada e responsável. O trágico não reside sequer na luta contra o ressentimento, a má consciência ou o niilismo. Nunca se compreendeu o que era o trágico segundo Nietzsche: trágico = alegre. Outra maneira de enunciar a grande equação: querer $=$ criar . Nunca se compreendeu que o trágico era positividade pura e múltipla, alegria dinâmica. Trágica é a afirmação: porque afirma o acaso e, do acaso, a necessidade; porque afirma o devir e, do devir, o ser; porque afirma o múltiplo e, do múltiplo, o uno. Trágico é o lance de dados. Todo o resto é niilismo, pathos dialético e cristão, caricatura do trágico, comédia da má consciência. ${ }^{198}$
\end{abstract}

É impossível saber como Oiticica usaria o seu "repertório", que inclui o lance de dados e o trágico, para articular seus vislumbres. Até a tentativa que fizemos de aproximar a interpretação de Deleuze a respeito do jogo de dados Nietzscheano das aparições dos dados e do acaso na obra de Oiticica é mera costura de fios soltos, um cozido de fragmentos, pois os conceitos de Nietzsche não são usados por Oiticica pelo que são na obra do filósofo alemão ou de seus comentadores. Como uma cuba de vidro que passa a integrar um bólide e a formar um todo tão íntegro que perde sua característica de "cuba" isolada, noções bastante complexas como o "lance de dados" são empregadas por Oiticica como parte que constituirá um todo a partir da vontade do artista. Mas podemos arriscar a dizer que o acaso que faz um lance de dados cair de volta com uma combinação vitoriosa é uma coincidência muito forte, quase uma necessidade (no sentido de inevitável) que, quando ocorre, sugere um encadeamento mágico ou ficcional de eventos, um "delírio concreto", capaz de embaralhar lugares e o tempo, como acontece no passeio de Oiticica pelo Rio em 1979:

(...) eu pego assim pedaços de asfalto na Avenida Presidente Vargas, antes de taparem o buraco do metrô, todos os pedaços de asfalto que tinham sido levantados... Quando eu apanhei esses

${ }^{197}$ NIETZSCHE, The Will to Power, op.cit., fr. 851. "O que é o trágico? Eu pus o dedo inúmeras vezes sobre o grande contra-senso de Aristóteles, quando ele acreditou ter reconhecido as emoções trágicas em duas emoções deprimentes, o terror e a piedade. Se ele tivesse razão, a tragédia seria uma arte perigosa para a vida; dever-se-ía evitá-la como um perigo público ou uma coisa inconveniente. A arte que é comumente o grande estímulo da vida, uma embriaguez de vida, uma vontade de viver, estaria, aqui, a serviço de um movimento de declínio e, como servidora do pessimismo, seria nociva à saúde (porque não é verdade, como Aristóteles parece acreditar, que despertando essas emoções nos purificamos). (...) tragédia é um tônico." (trad. livre da autora)

${ }^{198}$ DELEUZE, Gilles. Nietzsche e a Filosofia. Porto: Rés-Editora. 2a . edição, 2001, p. 56-57. 
pedaços de asfalto, eu me lembrei que CAETANO uma vez fez uma música, que disse até que pensou em mim depois que fez a música, que falava o negócio da "escola primeira da mangueira passa em ruas largas, passa por debaixo da avenida Presidente Vargas". Aí eu pensei assim: esses pedaços de asfalto... soltos, que eu peguei como fragmentos e levei para casa... agora, aquela avenida estava esburacada por baixo, e na realidade a estação primeira da mangueira vai passar por debaixo da Avenida Presidente Vargas... uma coisa que era virtual quando CAETANO fez a música, de repente se transformou num delírio concreto. O delírio ambulatório é um delírio concreto... ${ }^{199}$

A música que Oiticica cita de Caetano Veloso nesse trecho é "Enquanto seu lobo não vem." ${ }^{200}$, de 1968, música que invoca o prazer e o perigo do passeio labiríntico, liberação dionisíaca ameaçada da contenção repressora ${ }^{201}$, que acha veredas e caminhos no esconderijo subterrâneo, por debaixo das ruas $^{202}$, sugerindo a possibilidade de “estrutura aberta" semelhante aos conjuntos de penetráveis de Oiticica como Projeto Cães de Caça, Éden ou os subterranean Tropicalia Projects. A estrutura aberta da música propicia o "delírio concreto" de Oiticica, transformando-se em mapa de um lugar que Oiticica achou uma década depois de ouví-la. A música de Caetano fora citada também por Oiticica no texto de 1968, O sentido de vanguarda do grupo Baiano: a trama da terra que treme, no qual Oiticica arrisca dizer que a música de Caetano poderia ter sido um "prenúncio" da Passeata dos Cem Mil, cujos aspectos estéticos - a

${ }^{199}$ OITICICA, Hélio. Áudio da entrevista a Ivan Cardoso. Op. Cit.

${ }^{200}$ Vamos passear na floresta escondida meu amor/Vamos passear na avenida/ Vamos passear nas veredas, no alto meu amor/Há uma cordilheira sob o asfalto// (Os clarins da banda militar...)/ A Estação Primeira da Mangueira passa em ruas largas/(Os clarins da banda militar...)/ Passa por debaixo da Avenida Presidente Vargas/(Os clarins da banda militar...)/ Presidente Vargas, Presidente Vargas, Presidente Vargas/ (Os clarins da banda militar...)// Vamos passear nos Estados Unidos do Brasil/ Vamos passear escondidos/ Vamos desfilar pela rua onde Mangueira passou/ Vamos por debaixo das ruas// (Os clarins da banda militar...)/ Debaixo das bombas, das bandeiras/ (Os clarins da banda militar...)/ Debaixo das botas/ (Os clarins da banda militar...)/ Debaixo das rosas, dos jardins/ (Os clarins da banda militar...)/ Debaixo da lama/ (Os clarins da banda militar...) Debaixo da cama

${ }^{201}$ cf. FAVARETTO, Celso. Tropicália, alegoria, alegria. Cotia: Ateliê Editorial, 3a edição, 2000. p. 98102

${ }^{202}$ É interessante notar que o Zaratustra de Nietzsche usa recorrentemente o termo "go under" (ir por debaixo) na tradução de Walter Kaufmann (The Portable Nietzsche, op. cit.), diferentemente da tradução de Assim Falou Zaratustra para português (Obras Incompletas, op. cit.), que diz "sucumbir". Fiquemos por ora com Kaufmann : "I love those who don't know how to live, except by going under, for they are those who cross over" (Amo aqueles que não sabem como viver exceto passando por debaixo pois estes são os que atravessam.). O subterrâneo e o movimento de passar por debaixo são noções importantes para Oiticica a partir de 1969, que comentamos no capítulo 4 . 
visão de um coletivo onde cem mil tornam-se um único coro pelo ritmo das palavras de ordem - ecoam as idéias de Oiticica sobre síntese de individualidades e totalidades transformadoras de comportamento. A coincidência que levava alguns a relacionar a música de Caetano à passeata é explicada por Oiticica não como mero acaso, mas como conseqüência da estrutura aberta da letra de Caetano, propiciadora de "acasos" e conexões: um lance de dados vitorioso.

Seriam como as frases em passeatas: Ca-la-bou-ço, que ao serem repetidas vão-se incorporando, ritmicamente, aos sucessivos significados, ao coletivo e às vivências individuais. Lembro-me que durante a passeata dos cem mil vinha-me a todo momento, e também a amigos meus que conheciam a música, o ritmo e as frases de 'Enquanto seu lobo não vem'; "vamos passear na floresta escondida, meu amor, vamos passear na avenida, vamos passear nas veredas no alto..." Houve até quem achasse mais tarde que a música fora um prenúncio da passeata. Talvez, quem sabe, mas o que acontece é que Caetano constrói estruturas cada vez mais abertas à imaginação, logo à participação, de modo cada vez mais sintético. A percepção é uma totalidade, tratada como tal, e com isso suas experiências aparelham-se às que são feitas em todos os campos da vanguarda mundial. ${ }^{203}$

${ }^{203}$ OITICICA, Hélio. "A Trama da Terra que Treme (O Sentido de Vanguarda do Grupo Baiano)" AHO 280.68. É interessante confrontar a percepção de Hélio Oiticica sobre a musicalidade das palavras de ordem das passeatas com o seguinte trecho de VENTURA, Zuenir. 1968: o ano que não terminou. Rio de Janeiro : Nova Fronteira, 1989, p. 161-2 descrevendo a Passeata dos Cem Mil: "Eram 13h45min. A passeata começava a se movimentar em direção à Candelária. No meio da multidão se abriu um espaço para a segurança proteger as lideranças. Em ordem, os manifestantes tomaram então o caminho da avenida Rio Branco, cujo trânsito havia sido desviado pela polícia. Das janelas dos edifícios caía uma chuva de papel picado. Os estudantes olhavam para cima e gritavam 'desce, desce'. Para os populares que assistiam das calçadas, o convite era outro: 'Você que é explorado, não fique aí parado'. Essas rimas, repetidas por milhares de vozes, de forma cadenciada, compunham uma espécie de canção sem melodia, feita só de ritmo, mas ao mesmo tempo sonora, marcial, coletiva. Se cada época tem o seu som, o de 68 vai ser encontrado nas ruas, em meio aos ruídos de bombas, cascos de cavalos, sirenes." 


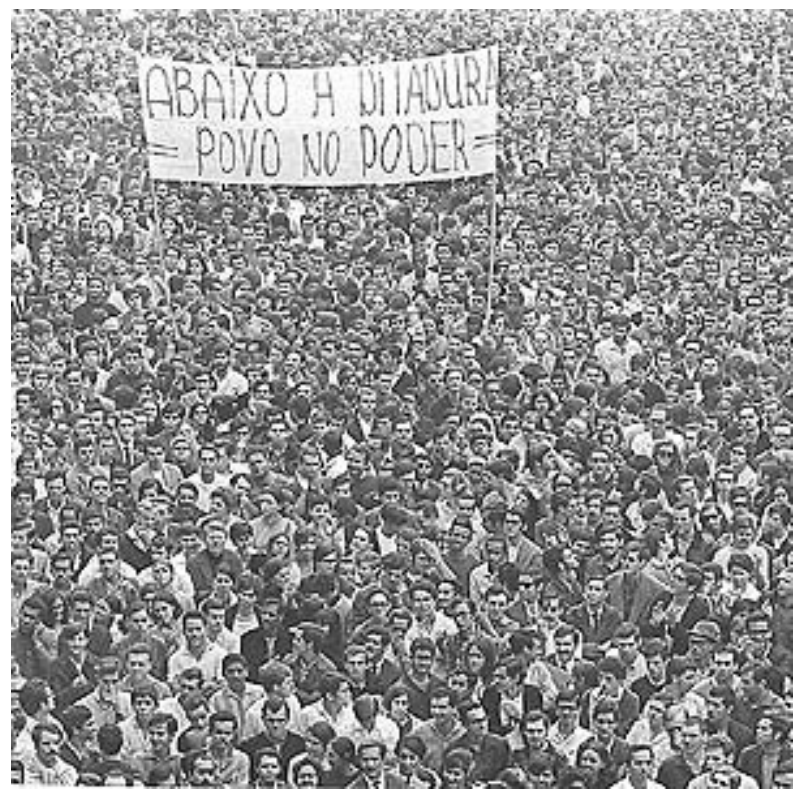

Passeata dos Cem Mil, 26/06/1968

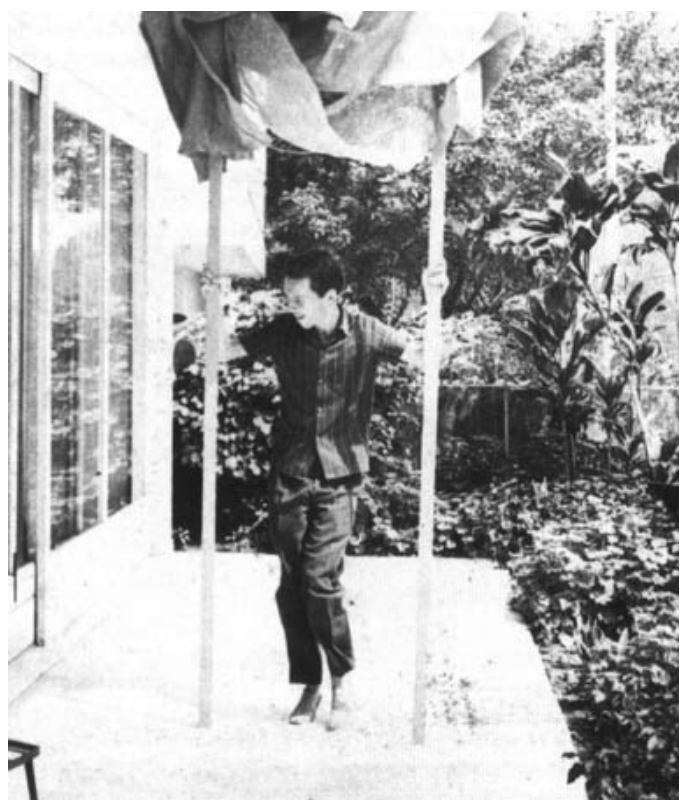

Hélio Oiticica com Estandarte n. 1 - Parangolé, 1964. AHO 1951.sd-p2

“A rua prá mim era um alimento também que contrapunha toda a coisa mais abstrata. Eu tinha uma tendência muito perigosa a me encerrar muito nas idéias, o que acontece com todos os artistas a meu ver." ${ }^{204}$ O vagar sem rumo ou objetivo para restaurar a capacidade criativa é o "dreamtiming" que Oiticica encontra descrito em texto de Mircea Eliade, um padrão social de tribos aborígenes no qual um indivíduo sai da taba e embrenha-se pela floresta, liberando-se de obrigações comunais e assim liberando novos pensamentos ${ }^{205}$. Oiticica concretizará o caminhar como proposição no Delirium ambulatorium, passeios pelo Rio de Janeiro em busca de encontros abertos, da mágica sensação de encontrar "por acaso" exatamente o que se estava procurando.

Oiticica oferece essa experiência a outros participantes no Programa in Progress CAJU, uma instância do Delirium Ambulatorium, que propõe aos participantes abordar-tomar o bairro do CAJU como um playground bairrourbano para curtir os achados $\rightarrow$

$\underline{\text { achar- }}$

${ }^{204}$ OITICICA, Hélio. Entrevista a Jary Cardoso, "Um Mito Vadio", Folhetim, 05/11/1978. AHO 944.78

${ }^{205}$ Para uma discussão da aparição de Mircea Eliade em textos de Oiticica, cf. VAZ, Suzana. "HO|ME Hélio Oiticica e Mircea Eliade; tendência para o concreto: mitologia radical de padrão iniciático " in Fios Soltos: a Arte de Hélio Oiticica op. cit. Não há indícios de que Hélio Oiticica tenha realmente lido obras de Eliade, mas o artista menciona ter ouvido de Guy Brett a descrição que Eliade faz do dreamtime. Os próximos capítulos exploram a noção de dreamtiming. 
play!

Esse achar-abordar-penetrar é sem-fim! Não só é ele performado in progress como por etapas de acordo com participantes/ propositores/ proposições feitas/ abordagens sugeridas/ programas limitados e/ou abertos propostos/idéias formuladas/ etc.

O CAJU É O GROUND

A PARTICIPAÇÃO DOS PARTICIPADORES FAZEM O PLAY. CAJU GROUND PARA O PLAY!

fazer do CAJU amigo

CAJU AMIGO ${ }^{206}$

Unindo o Caju aos participadores (amigo), ocorreria a síntese CAJU AMIGO ${ }^{207}$. Nem caju, nem amigo, nem uma seriação de caju e amigo, mas um elemento novo gerado da junção de partes. O bairro do Caju seria segundo Oiticica o "ground" e os participadores fariam o "play"208, palavra que pode ser entendida tanto como playbrincadeira, jogo, quanto como a tecla do toca-fitas, que grava e que reproduz fragmentos. "Achar-play” é junção, composição, ao acaso. É achar pelo jogo, ou achar e fazer música, como em uma brincadeira de fusão musical. A predileção de Oiticica pela palavra "síntese" e a importância da música, seja o samba ou o rock, em sua obra, nos sugerem que o "achar-play" pode ser uma referência aos "sintetizadores" de som populares nos anos 1960/ 1970. Lembremos que, para Oiticica, a música foi, desde os

${ }^{206}$ OITICICA, Hélio. "Memorando Caju”, 1979, op.cit.

${ }^{207}$ Caju Amigo é o nome de uma mistura de suco de caju e cachaça. Vele a pena lembrar um fragmento de Nietzsche certamente conhecido por Oiticica: "The artist gradually comes to love for their own sake the means that reveal a condition of intoxication: extreme subtlety and splendor of color, definiteness of line, nuances of tone: the distinct where otherwise, under normal conditions, distinctness is lacking. All distinct things, all nuances, to the extent that they recall these extreme enhancements of strength that intoxication produces, awaken this feeling of intoxication by association: the effect of works of art is to excite the state that creates art - intoxication." (O artista gradualmente passa a amar, sem outro motivo que eles mesmos, os meios que revelam uma condição de intoxicação: extrema sutileza e esplendor de cores, definição de linha, nuances de tonalidade: o distinto onde, de outra forma, sob condições normais, falta distinção. Todas as coisas distintas, todas as nuances, na medida em que lembram esses aumentos extremos de força que a intoxicação produz, despertam por associação esse sentimento de intoxicação: o efeito de obras de arte é excitar o estado que cria arte - intoxicação.). Fragmento 821, The Will to Power. Walter Kaufmann (ed.), op.cit., p. 434.

${ }^{208} \mathrm{O}$ "ground para play" de Oiticica é, como a forma da palavra comunica, o oposto da playgroundinização da cultura, do espetáculo alienado. Uma possível afinidade entre as propostas de Oiticica e um "playground" deve ser procurada na relevância do ato de brincar na constituição psíquica do bebê e da criança. Neste trabalho optamos por apenas usar as referências teóricas citadas por Oiticica, mas acreditamos que um estudo dessa obra à luz das teorias do psicanalista britânico Donald Winnicott seria revelador. cf. WINNICOTT, D. W. O Brincar e a Realidade. Rio de Janeiro: Imago Editora, 1975. 
anos 1960, exemplo de integração de partes em um todo fenomenológico, ou "fenômeno lógico": "Os núcleos, equali, para mim, são essencialmente musicais na sua relação de parte com parte, que, longe da seriação de elementos, compõem um todo fenômeno lógico." 209

\section{Música falada}

Oiticica identifica a estrutura de unidades autônomas dispostas em um conjunto (mundo erigindo mundo) na descrição do Bloco Cacique de Ramos que elabora em conversa com Carlos Vergara. A transcrição dessa conversa estaria na seção Rap in progress de Newyorkaises.

VERGARA, vou começar antes de mais nada por lhe propor algo q se destinaria à inclusão em NEWYORKAISES q se encontra em preparativos: essa proposição visa gerar levantamento e discussão de assuntos pertinentes a problemas q discuto nessa publicação e em geral na minha obra: problemas q the dizem também e q outros passarão a dizer, já q há a intenção de não só discutir como de lhe incorporar num determinado (ou vários determinados) veio (veios) de problemas e discussões q considero fundamentais: dizem-lhe respeito pela nossa ligação anterior assim como pelo nível seu de inteligência e atuar ${ }^{210}$ artístico $^{-1}$ q mais q nada me fazem iniciar a série RAP com você (...) $)^{211}$

Na conversa sobre o bloco Cacique de Ramos, os dois artistas discutem a multidão que participa do bloco carnavalesco formando um corpo só. Como diz Vergara “o bloco não exige de você uma performance especial como sambista, exige de você uma vontade de se juntar no fenômeno, coletivo, essa que é a única exigência que o bloco faz [...]"212. Para integrar o Cacique de Ramos, bastava que cada interessado comprasse a fantasia e colocasse fitas de esparadrapo no rosto, tiras imitando a pintura facial dos índios. E os dois artistas notam que é nessa marca de pertencimento ao grupo que cada um elaborava a sua distinção pois cada participante colocava o esparadrapo de uma forma

\footnotetext{
${ }^{209}$ OITICICA, Hélio. Sem título, 04/11/1960. AHO 0121.60-p30.

${ }^{210}$ no manuscrito, a caligrafia deixa dúvidas quanto a esta palavra, que optamos por transcrever como "atuar"

${ }^{211}$ OITICICA, Hélio. "Rap in Progress" - manuscrito de 28/10/1973. PHO 0393/73.

${ }^{212}$ OITICICA, Hélio e VERGARA, Carlos. Gravação de conversa em fita K-7, em 28/10/73, (Héliotapes), para a série "Rap in progress “ conforme transcrição de fitas feita por Eugênio Bressane em 20/08/81 PHO 0504/73.
} 
diferente no rosto: "então são 5 mil pessoas, um diferente do outro"213. A conversa entre Vergara e Oiticica prossegue num crescendo à medida em que Vergara descreve as ações do bloco, até a narração do momento em que parte da fantasia que cobre o corpo é jogada para o alto, ao que Oiticica responde com grande excitação: “e depois quando volta cai de volta!".

CV- É, as pessoas que estão participando de fora mas que não estão com a pele de Cacique, eles pegam a coisa do corpo e botam na cabeça, então trazem prá dentro então tem pessoa que tem calça e camisa normal mas ganhou uma parte da pele do Cacique e incorporado ao bloco, ao grupo que é uma maravilha, que é uma coisa maravilhosa, é uma coisa amorosa, sabe? ${ }^{214}$

Alguém do bloco joga a fantasia para o alto, um gesto de pura brincadeira e euforia. Alguém de fora do bloco coloca na cabeça a fantasia que retorna à terra, e passa a integrar o bloco, carregando a fantasia, como uma herança: "quando chega na Rio Branco, o bloco está pontilhado de pessoas exteriores que foram incorporadas, entendeu? Aquela multidão."

O bloco não tem hierarquias, nem dança ensaiada. Criação coletiva, com um protocolo mínimo tal como o uso de esparadrapos no rosto, o bloco de carnaval - música, ritmo, fantasia e acima de tudo corpo - é para Oiticica, ao lado dos grandes concertos de rock da virada da década de 1960 para 1970, uma forma de emergência do coletivo. O bloco tem ainda a característica fundamental de ser um fluxo, uma caminhada: um mundo movente que se constrói de blocos feitos de outros mundos em movimento.

IC - Você vê ligação das coisas que faz com outros artistas?

HO - Vejo assim uma ligação de famílias de inventores... De pontos luminosos como diria o

Haroldo, parafraseando Pound, que por sua vez já parafraseava Dante... Há coisas na história que me interessam sempre (...) quem ainda não descobriu a solidão, ainda não descobriu o estado de invenção. O estado de invenção é profundamente solitário, mas ele é profundamente coletivo. Tem uma coisa que eu sempre cito e que é uma constante em mim, que eu acho muito importante, que eu descobri em Nova Iorque, é uma coisa do Sartre, quando ele fala da posição do artista e do criador no mundo atual, que a gente está numa fase de emergência do coletivo, a

\footnotetext{
${ }^{213}$ Vale aqui lembrar que o todo, o UM, é entendido por Nietzsche apenas como organização de uma multiplicidade. Sobre isso, cf. MÜLLER-LAUTER, A Doutrina da Vontade de Poder em Nietzsche. S. Paulo: Annablume, 1997, p. 78

${ }^{214}$ OITICICA, Hélio e VERGARA, Carlos. op. Cit. PHO 0504/73.
} 
gente está numa passagem do individual, de valores individuais e individualistas para o coletivo, então na realidade a gente está dividido, entre o mais individual e ao mesmo tempo imergindo nessa emergência do coletivo. ${ }^{215}$

Mundo erigindo mundo precisa manter o caráter fluido da "contiguação", como uma simultaneidade de linhas melódicas soltas umas nas outras.

${ }^{215}$ OITICICA, Hélio. Áudio da entrevista a Ivan Cardoso. A transcrição desse trecho da entrevista publicada em Ivampirismo : o cinema em pânico, op. cit., possui algumas lacunas, omitindo a referência a Sartre e diz "uma coisa que eu sempre sinto" quando no áudio ouve-se "uma coisa que eu sempre cito". 


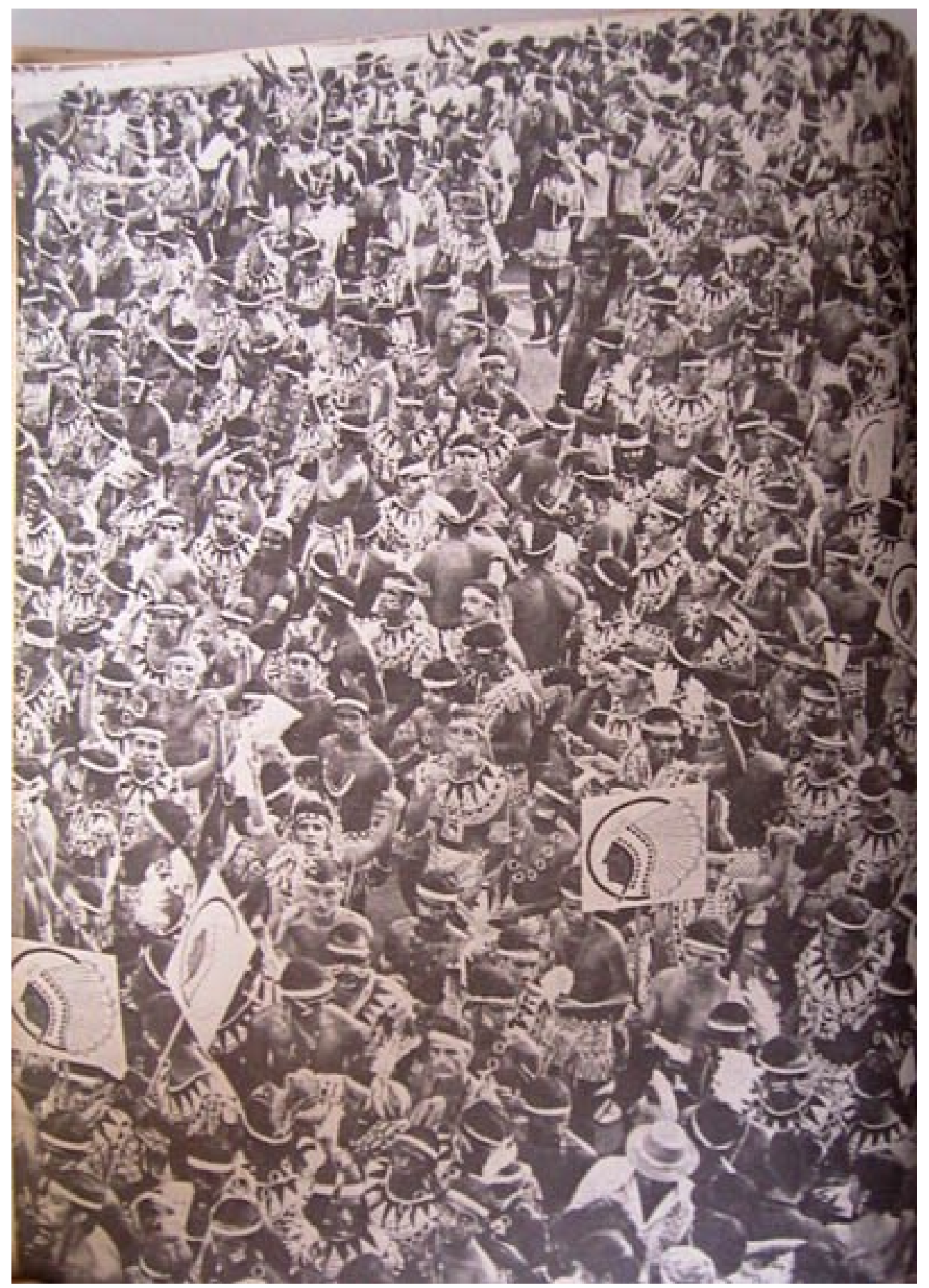

Reprodução da página 188 do catálogo de Information, exposição organizada por Kinaston McShine em 1970 no MOMA-NY, da qual Hélio Oiticica participou. O bloco carnavalesco retratado é o Cacique de Ramos. Os créditos da fotografia no catálogo são: "from Fatos e Fotos (Brasília), no. Especial, Carnaval 70, Feb. 19, 1970” 


\title{
2.6 Galáxia
}

\author{
Parafernália para Hélio Oiticica \\ Haroldo de Campos \\ 1. \\ retículas \\ redes desredes \\ reticulares ares áreas \\ tramas retramas redes \\ áreas \\ reticulares \\ reticulária \\ colares de quadrículos \\ contas cubículos \\ áreas ares \\ tramas retramas \\ desarticulária \\ de áreas reais \\ o rosto implode \\ camaleocaleidoscópico
}

Ao falar dos fios soltos do experimental, Oiticica cria uma imagem de leveza corroborada por outra expressão etérea: "pontos luminosos":

Mondrian, para mim, é um desses pontos luminosos... na realidade tem pontos e pontos luminosos... A tendência é só haver pontos luminosos, não interessa mais o artista de média, o artista que media, o artista não inventor não interessa mais, então para mim só interessa pontos luminosos: os artistas que são grandes inventores. ${ }^{216}$

Os pontos luminosos, conectados, formam uma galáxia ${ }^{217}$ que pode ser entendida como o "céu" de um modelo de mundo bastante fiel à terra: é nessa trama dos inventores luminosos que talvez esteja a "metafísica de artista" de Oiticica.

Haroldo de Campos foi quem melhor associou o céu, a leveza e o vôo às proposições de Oiticica. Antes de definir o parangolé como "Asa Delta para o Êxtase", imagem vinculada à visualidade do Rio de Janeiro, o poeta havia comparado a invenção

\footnotetext{
${ }^{216}$ OITICICA, Hélio. Áudio da entrevista a Ivan Cardoso, 1979. Na transcrição dessa entrevista publicada em Ivampirismo: o cinema em pânico, op. cit. não há verbo nessa frase e lê-se "o artista que média". No áudio fica claro que Oiticica está conjugando o verbo mediar: "o artista que media".

${ }^{217}$ É interessante lembrar que as primeiras Galáxias de Haroldo de Campos foram publicadas em 1964 na revista Invenção. cf. AGUILAR, Gonzalo, op. cit e Heliotapes, transcrição em PHO 396/71
} 
de Oiticica ao manto de plumas de Hagoromo, peça do teatro Nô. O manto de plumas divino é esquecido na terra por um anjo, a Tennin, "espécie de fada ou ninfa lunar"218 que, para recuperá-lo, dança sob exigência de um pescador. Haroldo de Campos narra: “Ao executar a dança, caem do céu as benesses, os bens, sobre a terra, e a peça termina com o manto se dissolvendo no céu do céu, quer dizer, no branco do branco, no éter do éter. Um final "suprematista",. ${ }^{219}$

Em um texto bastante conhecido de Oiticica "Anotações sobre o Parangolé”, a dança é o que revela a estrutura da obra, suas camadas, os diversos pedaços que a compõem. Dançando com o "manto" parangolé, o participador recebe a grande benesse, a "vivência mágica" proporcionada pelo "espaço ambiental”:

\begin{abstract}
Desde o primeiro "estandarte", que funciona com o ato de carregar (pelo espectador) ou dançar, já aparece visível a relação da dança com o desenvolvimento estrutural dessas obras da "manifestação da cor no espaço ambiental". Toda a unidade estrutural dessas obras está baseada na estruturação que é aqui fundamental; o "ato" do espectador ao carregar a obra, ou ao dançar ou correr, revela a totalidade expressiva da mesma na sua estrutura: a estrutura atinge aí o máximo de ação própria no sentido do "ato expressivo". [...] A criação da "capa" (já realizada a 1 e a 2) veio trazer não só a questão de considerar um "ciclo de participação" na obra [...] mas também a de abordar o problema da obra no espaço e no tempo - não mais como se fosse "situada" em relação a esses elementos, mas como uma "vivência mágica" dos mesmos ${ }^{220}$.
\end{abstract}

\footnotetext{
${ }^{218}$ CAMPOS, Haroldo de. Hagoromo de Zeami: o charme sutil. São Paulo: Estação Liberdade, 1993, p. 13. Oiticica provavelmente leu trabalhos preliminares à publicação do livro. Haroldo de Campos conta na introdução de Hagoromo de Zeami: o charme sutil que vinha trabalhando no texto desde 1960. O poeta conta que dedicou a tradução do "Canto final do coro" a Hélio Oiticica, fazendo um paralelo entre o manto e o parangolé: "Além das cartas que trocamos à época, as impressões de Hélio, instigadas por esse paralelo, estão vivamente registradas em seu diário novaiorquino (1973), que pude consultar graças a Luciano Figueiredo, curador do acervo do artista. Hélio chegou a imaginar a possibilidade de uma parangoplay ("parangopeça")", p. 17. É interessante notar que na edição de 1993, Haroldo de Campos inseriu como primeira página duas fotografias lado a lado: a Tennin com seu manto e Luís Fernando Guimarães com um parangolé. Haroldo de Campos inclui ainda em seu texto uma nota de rodapé (nota 6, pag. 26) que fala de um projeto Parangoromo de encenação da peça Nô por ele traduzida, com participação de Caetano Veloso e dirigido por Julio Bressane, que substituiria o manto de plumas por um parangolé. O projeto estaria a cargo da atriz e teatróloga Alicek. Não temos notícia de que já tenha sido realizado.

${ }^{219}$ CAMPOS, Haroldo de. "Asa Delta para o Êxtase". Hélio Oiticica, op.cit., p. 217-21.

${ }^{220}$ OITICICA, Hélio. "Anotações sobre o Parangolé” em . Aspiro ao Grande Labirinto, op.cit. p. 70
} 
[...] meu interesse pela dança, pelo ritmo, no meu caso particular o samba, me veio de uma necessidade vital de desintelectualização [...] Seria o passo definitivo para a procura do mito ${ }^{221}$ para a retomada desse mito e uma nova fundação dele na minha arte. É portanto, para mim, uma experiência da maior vitalidade, indispensável, principalmente como demolidora de preconceitos, estereotipações, etc. A dança é por excelência a busca do ato expressivo direto, da imanência deste ato; não a dança de balé, que é excessivamente intelectualizada pela inserção de uma "coreografia" e que busca a transcendência deste ato, mas a dança "dionisíaca", que nasce do ritmo interior do coletivo, que se externa como característica de grupos populares, nações etc. $[\ldots]^{222}$

$\mathrm{Na}$ dança, Oiticica vislumbrava uma simultaneidade entre o individual e o coletivo - "há como uma imersão no ritmo, uma identificação vital completa do gesto, do ato com o ritmo, uma fluência onde o intelecto permanece como que obscurecido por uma força mítica interna individual e coletiva (em verdade não se pode aí estabelecer a separação)"223. Esse jogo do individual e do coletivo é articulado por Oiticica pela expressão "dança dionisíaca” que ele toma emprestada de Nietzsche que, lembremos, "só acreditaria em um deus que soubesse dançar." 224

Podemos então entender o espaço ambiental de Oiticica como um espaço que dissolve fronteiras entre o intelectual e o mítico, espaço acionado pela estrutura da obra. A dança é o ato em si, pura imanência, mas capaz de invocar o "dionisíaco", o coletivo, um estar no mundo que é ao mesmo tempo imanente e mágico. $\mathrm{O}$ transcendente é aqui substituído pelo "ambiental”, espaço de vivências mágicas proporcionadas por estruturas terrenas.

\footnotetext{
${ }^{221}$ O mito, citado nesse trecho de 1964, passa por uma reviravolta na obra de Oiticica na década seguinte, quando o artista empreende seu "processo de desmitificação", que será comentado mais adiante nesse texto.

${ }^{222}$ OITICICA, Hélio. Aspiro ao Grande Labirinto, op.cit., 73.

${ }^{223}$ Ibid.

${ }^{224}$ NIETZSCHE, Friedrich. "Thus Spoke Zarathustra: First Part (On reading and writing)" in The Portable Nietzsche, op.cit, p.153. "I would believe only in a god who could dance (...) Now I am light, now I fly, now I see myself beneath myself, now a god dances through me.”(Eu só acreditaria num deus que soubesse dançar. (...) Agora estou leve; agora vôo; agora me vejo debaixo de mim mesmo; agora um deus dança por meu intermédio. - trad. livre da autora)
} 


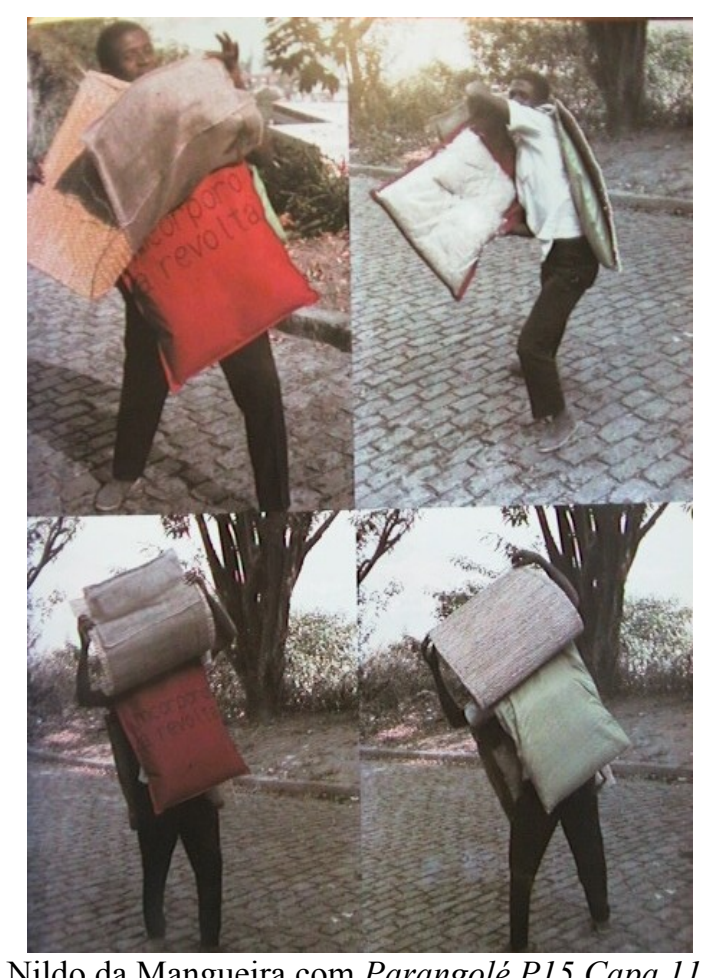

Nildo da Mangueira com Parangolé P15 Capa 11, Incorporo a Revolta, 1967

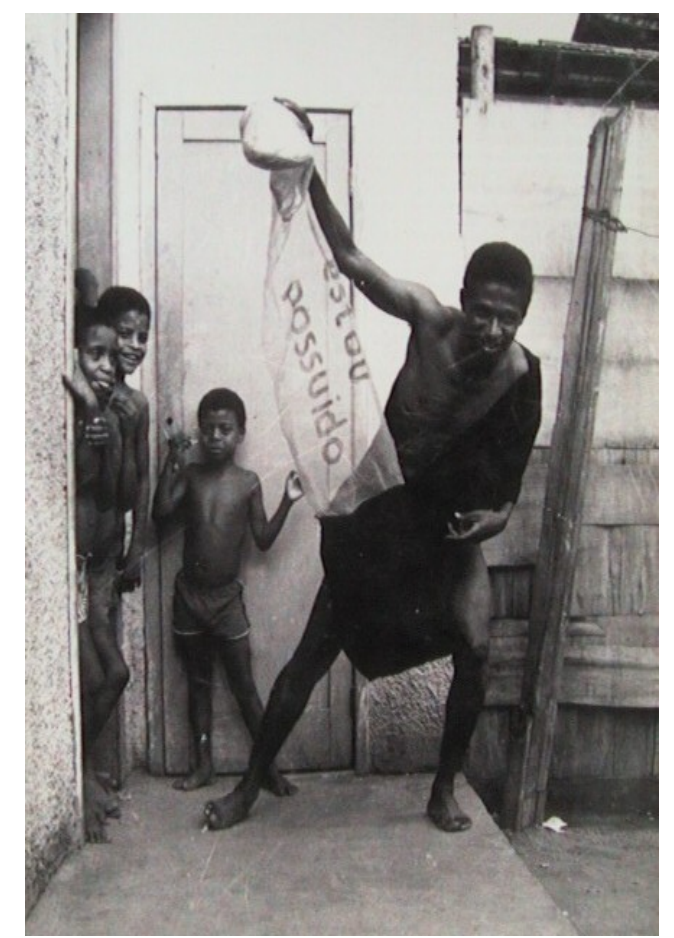

Nildo da Mangueira com Parangolé P17, Capa 13, Estou Possuído, 1967.

As imagens de Nildo da Mangueira com P15 capa 11, Incorporo a Revolta, de 1967 sugerem o movimento do sambista com a pesada capa. Com travesseiros pendurados em seu corpo, Nildo é movido pela capa. Quando usado por uma pessoa parada, este parangolé restringe os movimentos do participante, mas assim que ele começa a dançar, o peso da capa adiciona impulso a seus movimentos e o arremessa para mais longe, ao mesmo tempo em que tais movimentos revelam o verso "incorporo a revolta", escrito em uma das almofadas. Nessa "incorporação", Nildo não é guiado por uma entidade sobrenatural mas sim pelo peso da capa, que o incita a transformar sua revolta em movimento através da dança.

Em outra fotografia, Nildo veste uma toga preta, Parangolé 17 Capa 13, Estou Possuído, também de 1967. Nesse exemplo, Nildo está possuído pelo espírito intoxicador da dança, como revela a bela pose e o movimento amplo de seus braços. A frase "Estou Possuído" anuncia seu estado impulsivo, propenso a mudanças, dança e parangolé 
conduzindo-o a uma atitude além daquelas possíveis a um homem não possuído pela dança.

Além de associar os parangolés ao vôo, Haroldo de Campos insiste na idéia de leveza ao enfatizar a transparência e luminosidade das tramas que aparecem como matéria de construção dos ninhos de Hélio Oiticica. A trama transparente é também matéria de que são feitos parangolés, como Capa 23 M'way Ke, e os delimitadores suaves de espaços nas maquetes e labirintos de Oiticica.

Haroldo de Campos identificou nos "ninhos de plástico de fios luminosos" que conheceu no apartamento de Oiticica em Nova Iorque um "caráter quase de nós espaciais, onde a pessoa se integrava, se embrulhava, assumia uma condição quase que entre fetal e aérea, uma espécie de placenta luminosa e sem gravidade, uma gravidez sem gravidade que ele abria para o vôo espacial."225

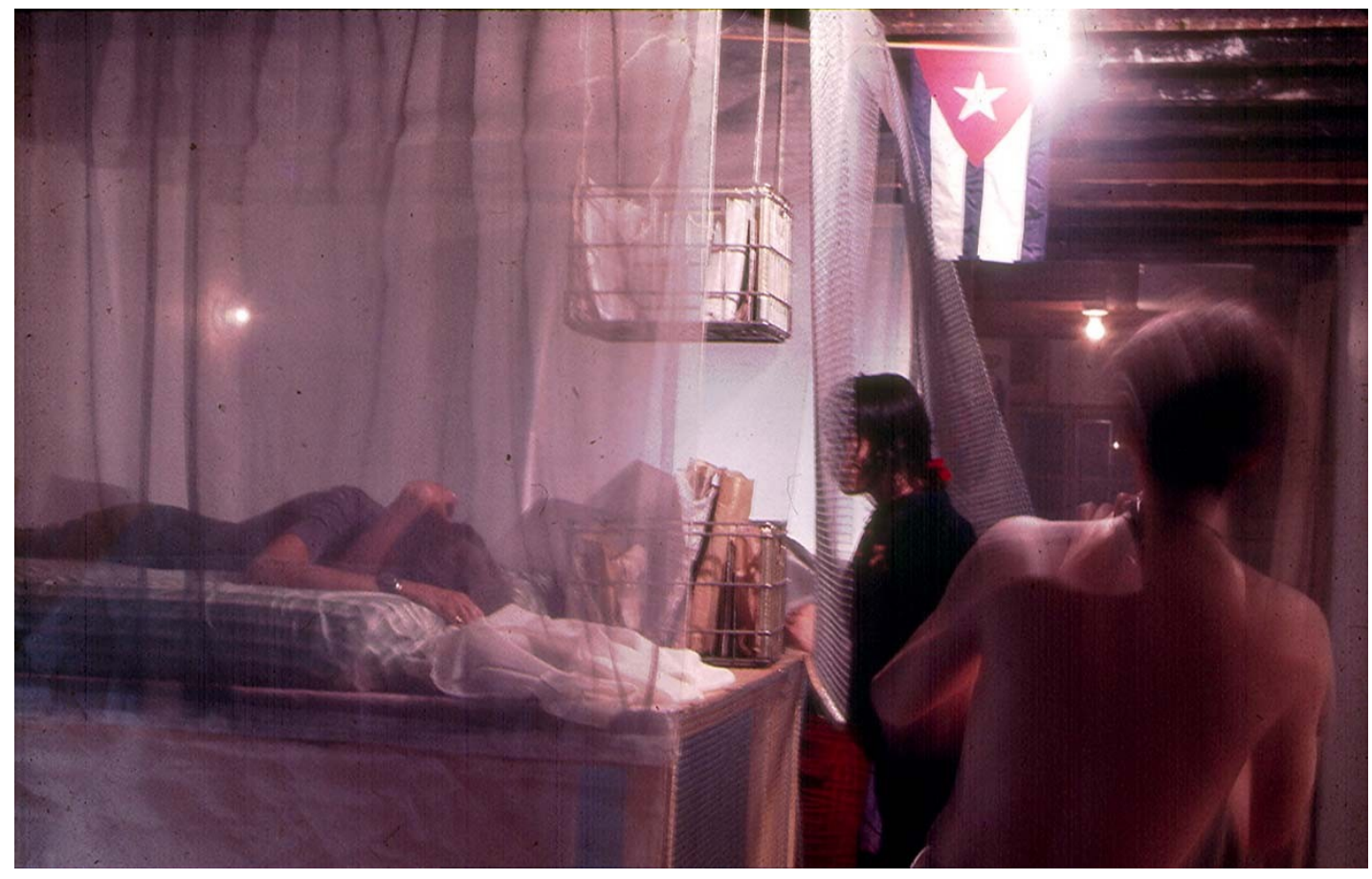

Ninhos no Loft 4 de Nova Iorque (Babylonests). AHO 2126.71

${ }^{225}$ CAMPOS, Haroldo de. "Asa Delta para o Êxtase”. Op. Cit. 
Etéreas são as fotografias que Oiticica fez de seus amigos em topos de prédios de Nova Iorque vestindo parangolés. Na fotografia de Luís Fernando Guimarães vestindo o Parangolé Capa 23 o ator do teatro Oficina está envolto por uma tela diáfana, como se aguardasse o vento propício à flutuação no ar. Linhas mais grossas -- as costuras -- conectam os vértices da estrutura transparente que o envolve, cujo geometrismo assemelha-se aos Relevos Espaciais do final da década de 1950, estruturas também flutuantes que, soltas no ar, suspensas apenas por um fio, fazem circular as várias faces de uma sobreposição, intersecção de planos.

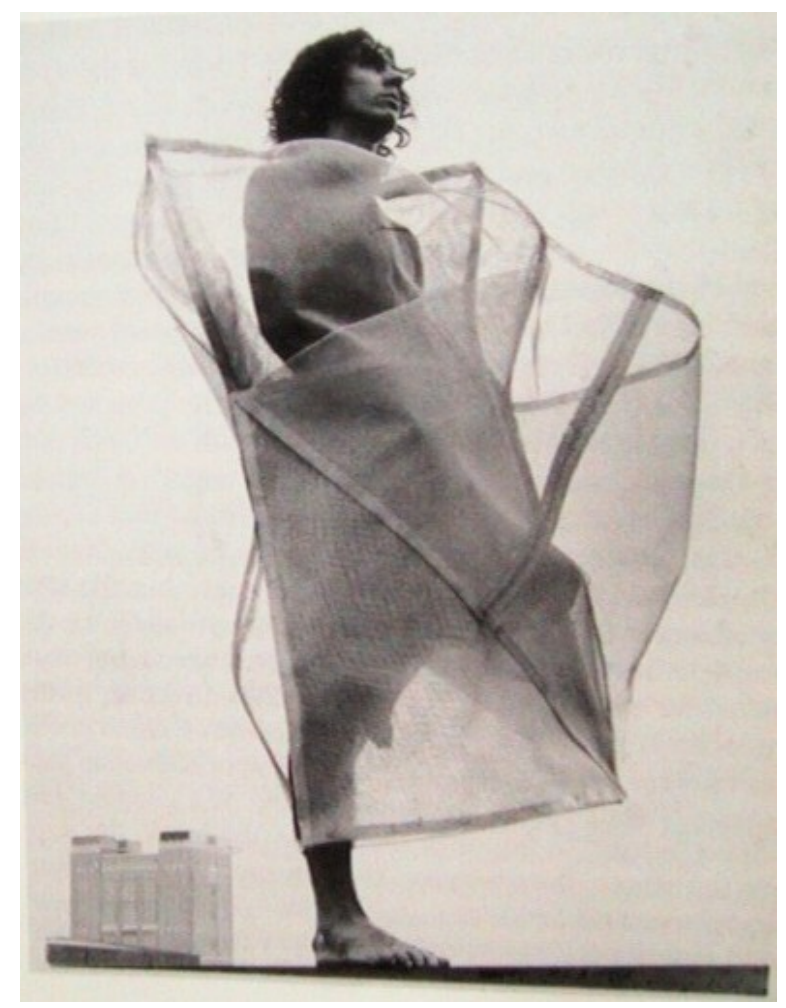

Luís Fernando Guimarães com Parangolé Capa 23 P30 M’way Ke, Nova Iorque, 1972

A trama, seja como material de ninhos ou como estrutura que conecta e intercepta os pensadores citados nos textos de Oiticica, é um espaço mágico de gestação. Tanto Hélio quanto os outros pontos luminosos dessa trama são propositores de um estado de invenção. É a partir da trama de inventores, dos pontos de intersecção dos fios deixados 
soltos em movimento por muitos artistas e filósofos, dos planos que flutuam e sobrepõem-se por alguns instantes, que surge a invenção de Hélio Oiticica.

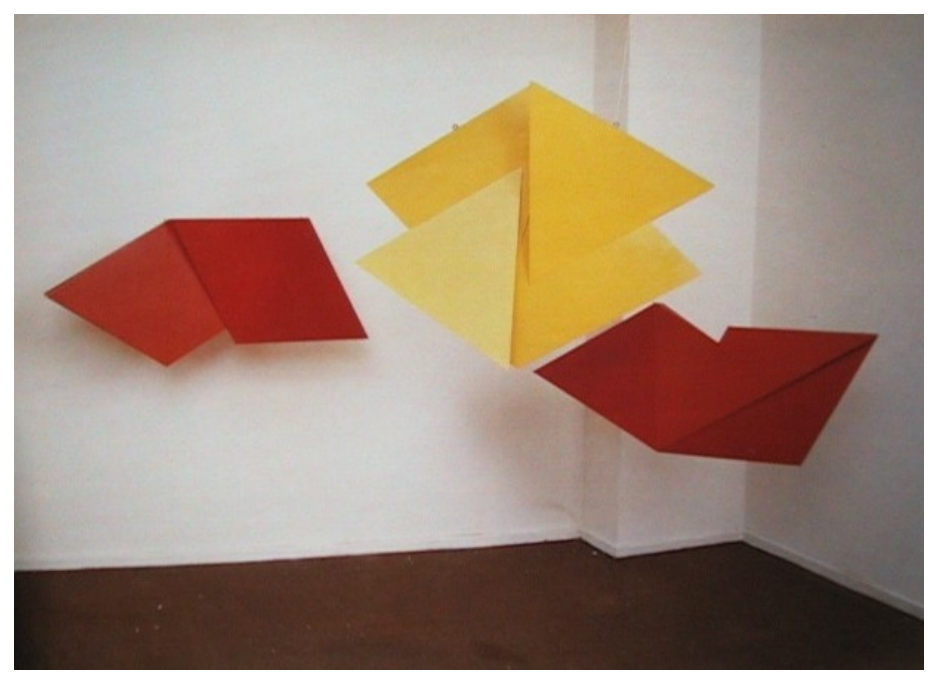

Relevos espaciais, óleo sobre madeira, 1959

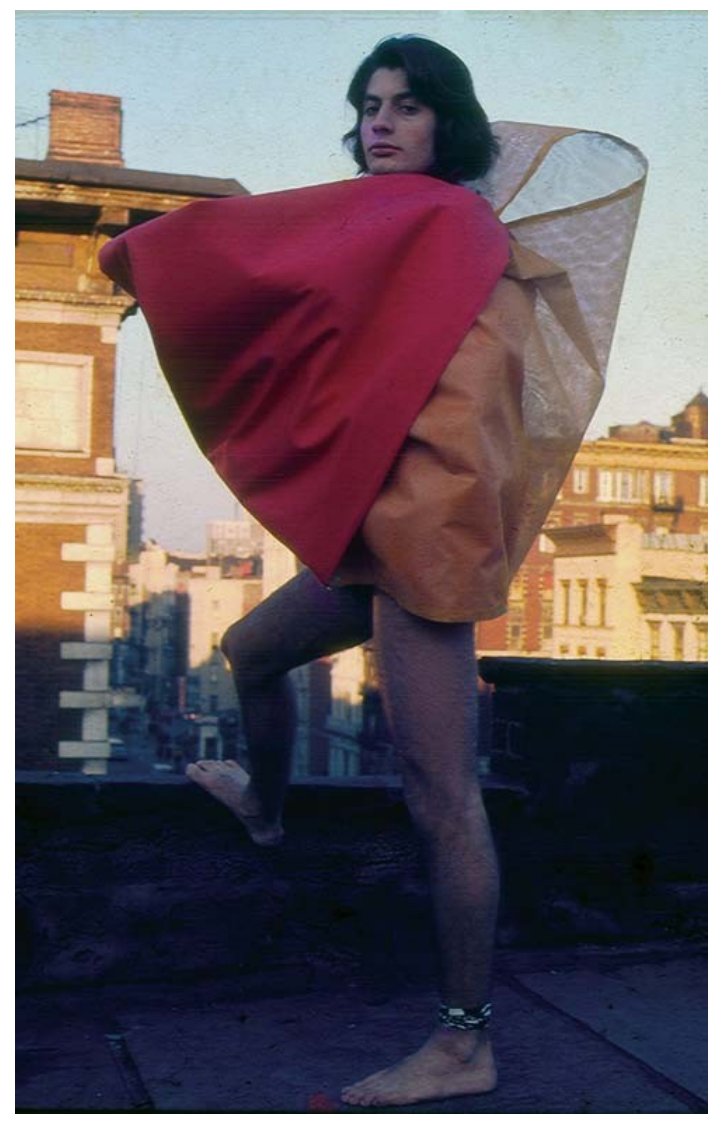

Romero com Parangolé Capa 25 P32, New York City, 1972. 


\section{Conceitualismo e vivência}

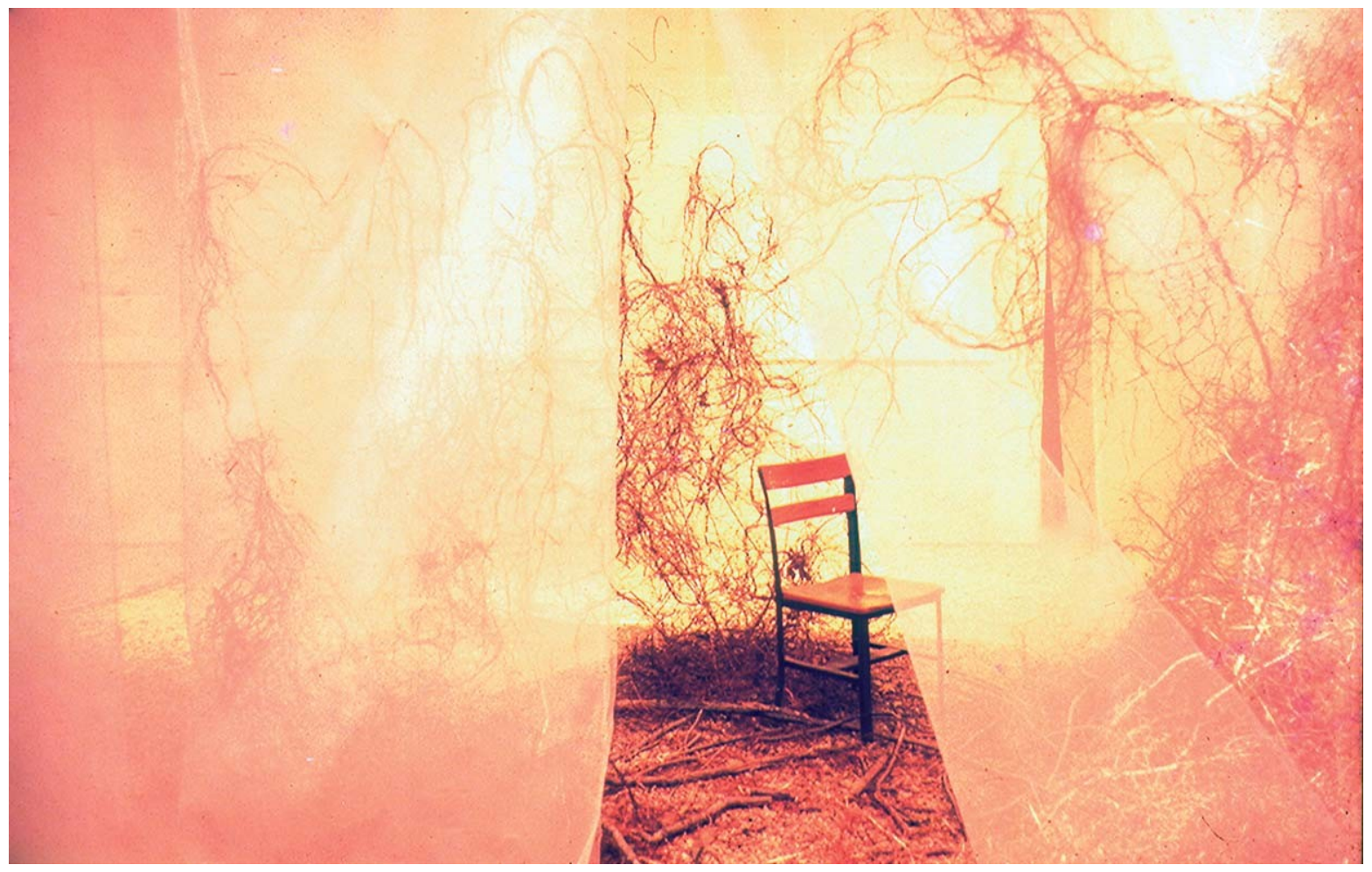

Hélio Oiticica. Instalação feita na Universidade de Rhode Island em 1971 no evento Rhodislândia. Foto de Hélio Oiticica. AHO 2128.71-p8 


\subsection{Conceitual + Sensorial $=$ Experimental}

$\mathrm{Na}$ virada da década de 60 para 70, em Londres e depois em Nova Iorque, Oiticica teve contato com outros artistas que, movendo-se em diferentes direções e intensidades, interessavam-se, naquele momento, mais por investigar a elasticidade da arte do que por produzir obras sucessivas num mesmo ponto da extensão. ${ }^{226}$ Seus escritos mostram familiaridade com obras de Vito Acconci, Yoko Ono, Exploding Galaxy, um contato pessoal com a crítica de arte Lucy Lippard -- que cunhou o termo desmaterialização do objeto de arte ${ }^{227}$ - assim como envolvimento com ao menos dois veículos que na época foram muito importantes na disseminação dessas pesquisas: a revista britânica Studio International e a exposição Information (julho a setembro/1970), no MOMA-NY.

Na revista, Oiticica apareceu em uma entrevista concedida a Guy Brett na época da Whitechapel Experience ${ }^{228}$, e no final de 1969, enviou para a Studio International o artigo "The senses pointing towards a new transformation", que nunca foi publicado. Em Information, Oiticica ocupou uma grande sala com os ninhos, publicou um texto no catálogo e provavelmente foi o responsável pela fotografia do bloco Cacique de Ramos que aparece na seleção de imagens das últimas páginas do catálogo, ao lado de outras fotografias "de época" como o homem andando na lua, cenas de Woodstock, imagens da guerra do Vietnã, atos pacifistas, a imagem de Yves Klein supostamente levitando e

\footnotetext{
226 Escolhemos a "elasticidade da arte" para caracterizar o objeto de pesquisa do grupo a que nos referimos a partir da menção que Oiticica faz à Hide-and-Seek Piece de Yoko Ono: "borracha que é estendida de um estado natural (encolhida) a uma extensão infinita no espaço no tempo e no comportamento como elementos existenciais" (cf. OITICICA, Hélio. "Yoko Ono and Grapefruit", 13/09/1973 AHO 189.73-p49.) Das produções com as quais teve contato direto em Londres e Nova Iorque, o trabalho de Yoko Ono é o que mais impressiona Oiticica, comentado no capítulo 4.

${ }^{227}$ Six years: the dematerialization of the art object from 1966 to 1972. LIPPARD, Lucy (ed.) Londres: Studio Vista, 1973. Oiticica conheceu Lippard em Nova Iorque, conforme carta para Lygia Clark de 24/01/1972 em CLARK, Lygia e OITICICA, Hélio. Lygia Clark - Hélio Oiticica: Cartas, 1964-74,.op.cit., p. 218

${ }^{228}$ cf. OITICICA, Hélio. "Hélio Oiticica retrospective at the Whitechapel Gallery, until April 6: Oiticica talks to Guy Brett". Studio International, Março/1969, v. 177 no. 909, p. 134. Durante o período da exposição na Whitechapel Gallery, a revista Art and Artists, também londrina, OITICICA, Hélio. "On the discovery of creleisure", Art and artists, Londres, Abril/1969.v. 4 no. 1
} 
Marcel Duchamp jogando xadrez com uma jovem nua ${ }^{229}$. A intersecção ${ }^{230}$ entre as páginas da Studio International de 1969-1970 e do catálogo Information inclui, além de Hélio $^{231}$, Sol LeWitt ${ }^{232}$, Carl Andre ${ }^{233}$, Robert Smithson ${ }^{234}$, Joseph Kosuth ${ }^{235}$, Victor Burgin $^{236}$, Daniel Buren ${ }^{237}$, Richard Long ${ }^{238}$, Lucy Lippard ${ }^{239}$ e Gilbert and George, ${ }^{240}$ nomes que indicam a diversidade da cena artística na virada das décadas de 1960 para 1970.

${ }^{229}$ A fotografia de Duchamp defronte ao Grande Vidro, jogando xadrez com a futura cronista da vida californiana Eva Babitz, foi feita por Julien Wasser no Pasadena Art Museum em 1963, durante a retrospectiva da obra de Duchamp.

${ }^{230}$ Registramos aqui os artistas que participaram de Information e que assinam eles mesmos os textos ou projetos publicados na Studio International entre janeiro de 1969 e dezembro de 1970. Esse período foi escolhido por aproximadamente coincidir com a estadia de Oiticica na Inglaterra (dezembro/68 a dezembro/69) e com os preparativos de Oiticica para Information, que ficou em cartaz de julho a setembro de 1970. É bastante provável que Oiticica tenha lido alguns desses números da Studio International de 1969, já que sua entrevista a Guy Brett foi publicada nessa revista em março e, como veremos ao longo desse capítulo, ficou em contato com a revista até pelo menos maio de 1970 aguardando a aceitação ou recusa de seu artigo "The Senses Pointing Towards a New Transformation". Não citamos artistas mencionados em textos críticos de outrem. Em vários casos, a Studio International publicou obras ou registros de obras recentes desses artistas, e funcionou como suporte para esses trabalhos (cf. Gilbert and George) ou espaço alternativo para exposição (cf. Lucy Lippard, Sol LeWitt e Robert Smithson). Alguns textos publicados na Studio International que aqui comentamos foram republicados em Conceptual Art: a critical Anthology ALBERRO, Alberto and STIMSON, Blake (eds.). Cambridge: MIT Press, 1999 e em Art in Theory 1900-1990: an Anthology of Critical Ideas. HARRISON, Charles and WOOD, Paul (eds.). Oxford: Blackwell Publishers, 1992. Charles Harrison era editor assistente da Studio International no período que selecionamos para essa pesquisa.

${ }^{231}$ OITICICA, Hélio. "Hélio Oiticica retrospective at the Whitechapel Gallery, until April 6: Oiticica talks to Guy Brett". Studio International, Março/1969, v. 177 no. 909, p. 134.

${ }^{232}$ LEWITT, Sol. "Drawing Series 1968 (Fours)". Studio International, vol. 177 n. 910 (Abril 1969), p. 189.

${ }^{233}$ ANDRE, Carl. “An opera for three voices”. Studio International, vol. 177 n. 910 (Abril/1969), p. 176-9. Trata-se de uma partitura para 3 vozes: De Kooning, Pollock e Gorky.

${ }^{234}$ SMITHSON, Robert. "Aerial Art". Studio International, vol. 177 no. 910 , (Abril/1969), p.180-1. Comentado adiante no texto. Republicado em The writings of Robert Smithson. HOLT, Nancy (ed.). New York: New York University Press, 1979.

${ }^{235}$ KOSUTH, Joseph. "Art after Philosophy". Studio International. Primeira parte (v. 178 n. 915, outubro 1969, p. 134-7); segunda parte (v. 178 n. 916, novembro 1969, p. 160-1); terceira parte (v. 178 n. 917 , dezembro 1969, p. 212-13). Republicado em Conceptual Art: a critical anthology op.cit. e em Art in Theory 1900-1990: an Anthology of Critical Ideas, op.cit.

${ }^{236}$ BURGIN, Victor. "Situational Aesthetics". Studio International. vol. 178 n. 915 (Outubro, 1969), p. 11821. Republicado em Art in Theory 1900-1990: an Anthology of Critical Ideas, op.cit.

${ }^{237}$ BUREN, Daniel. “Beware!”, Studio International, vol. 179, n. 920 (Março, 1970), p. 100-104. Repulicado em Conceptual Art: a critical Anthology, op.cit. e em Art in Theory 1900-1990: an Anthology of Critical Ideas, op.cit. Traduzido para português em Escritos de artistas: anos 60/70. FERREIRA, Glória e COTRIM, Cecília (orgs.). Rio de Janeiro: Jorge Zahar, 2006.

${ }^{238}$ LONG, Richard. "Nineteen Stills from the work of Richard Long". Studio International. vol. 179, n. 920 (March, 1970), p. 106-111. Essa publicação não se trata de um texto mas de reproduções de fotografias, registros de obras de Long, com legendas. 
O catálogo de Information é um exemplo do uso que vários artistas passaram a fazer de publicações impressas no final da década de 1960, usando-as como espaço para exposição mais adequado a suas obras do que galerias ou museus ${ }^{241}$. Cada artista pôde escolher como gostaria de ser "representado" no catálogo ${ }^{242}$, o que talvez tenha inspirado a declaração de Oiticica no catálogo: “eu não estou aqui representando o Brasil nem qualquer outra coisa. As idéias de representar-representação-etc acabaram (...) é importante que as idéias de ambiente, participação, etc., não sejam limitadas a soluções de objeto; elas deveriam propor o desenvolvimento de atos de vida, e não uma representação a mais (a idéia de 'arte')."

Para vários contemporâneos internacionais de Oiticica, a obra não poderia continuar a ser um objeto de qualidades estéticas para consumo do "público cultivado", nem alvo de um olhar dissociado do corpo, tampouco janela para devaneios reconfortantes num mundo em acelerado e violento processo de reconfiguração que, ao final da década de 1960, exigia uma associação entre contestação estética e contestação política. ${ }^{243}$ Kinaston Mcshine descreve o clima sócio-político que envolvia essas

\footnotetext{
${ }^{239}$ LIPPARD, Lucy, “Groups”. Studio International, v. 179, n. 920 (Março, 1970), p.93-9. A autora que em 1973 lançaria a Six years: the dematerialization of the art object from 1966 to 1972 publica na Studio International o resultado de um projeto artístico que consistia em pedir para 30 pessoas (estudantes, pintores e escultores) que fotografassem todos os dias durante uma semana o mesmo grupo de 5 ou mais pessoas e fornecessem junto das fotografias uma descrição por escrito das fotos. Lippard montou uma exposição com o resultado do projeto e escreveu nas páginas da Studio International que considerava a exposição 'transferível' para outras mídias, como a própria revista.

${ }^{240}$ GILBERT and GEORGE. "A Magazine Sculpture”. Studio International, v. 179 n. 922 (Maio/1970), p.218-21. Trata-se de uma declaração de intenções da dupla recém formada, com propostas tais como "estar sempre muito bem vestidos, bem arrumados relaxados amistosos finos e em controle total (...) nunca problematizar julgar discutir ou criticar mas permanecer quietos respeitosos e calmos". É importante ressaltar a intenção da dupla em utilizar a revista como suporte para o trabalho, explícita no título da obra ("Uma escultura para revista").

${ }^{241}$ Para um apanhado histórico do uso das páginas de revistas e catálogos como espaço de exposição, cf. RORIMER, Anne. "Siting the page: Exhibiting Works in Publications - Some Examples of Conceptual Art in the USA" in Rewriting Conceptual Art. NEWMAN, Michael and BIRD, Jon (eds.). Londres: Reaktion Books, 1999, p. 11-26.

${ }^{242}$ Jan Dibbets revela esse procedimento de consulta aos artistas escolhendo para 'representá-lo' o próprio formulário enviado pela curadoria aos artistas. Assim, na página dedicada a Dibbets encontra-se o questionário: "como você gostaria de ser representado no catálogo? Cada página é do tamanho dessa folha e cada artista terá uma página. Fotografias da peça apresentada na exposição? Fotografias de uma peça mais antiga? Outras fotografias? Um 'statement'? De alguma outra forma?" Dibbets respondeu "por esse papel", datou-o e assinou-o nos campos indicados.

${ }^{243}$ cf. FAVARETTO, Celso. "Inconformismo estético, inconformismo social, Hélio Oiticica" in Fios Soltos: A Arte de Hélio Oiticica, op. cit.
} 
produções em texto do catálogo da mostra Information, no MOMA-NY, de julho a setembro de 1970:

Se você é um artista no Brasil, você sabe de ao menos um amigo que está sendo torturado; se você é um artista na Argentina, você provavelmente teve um vizinho preso por usar cabelos compridos ou por não estar "vestido" corretamente; e se você vive nos Estados Unidos, você pode temer ser baleado ou na universidade, ou na sua cama, ou mais formalmente na Indochina. Pode parecer muito inapropriado, ou mesmo absurdo, levantar-se de manhã, entrar numa sala e aplicar pinceladas de tinta vinda de um pequeno tubo a uma tela quadrada. $\mathrm{O}$ que você pode fazer como jovem artista que lhe pareça relevante e significativo? (...) uma alternativa tem sido estender a idéia de arte, renovar sua definição, e pensar para além das categorias tradicionais pintura, escultura, desenho, gravura, fotografia, teatro, música, dança e poesia. ${ }^{244}$

Ao pensar "para além das categorias tradicionais" da arte, muitos desses artistas voltaram-se para o texto, prática comum nas vanguardas modernistas européias e que sofrera uma diminuição de intensidade durante as décadas de 1940 e 1950 . A prática da escrita e publicação de manifestos e revistas, que nas primeiras décadas do século $\mathrm{XX}$ brotavam simultaneamente à produção material de Kandinsky, Mondrian, Maliévitch, Schwitters, e dos surrealistas e futuristas, não teve continuidade no novo centro das artes: o expressionismo abstrato norte-americano foi pintado por artistas e escrito por críticos de arte.

Na década de 1960, no entanto, muitos artistas voltam a reivindicar o direito de escrever sobre a própria obra. Contestam, assim, uma certa organização política do sistema da arte. O "trabalho" do artista passa a incluir a teorização. A reivindicação da autoridade intelectual que ficou por mais de uma década a cargo de críticos foi tema de uma obra de Carl Andre, Opera for 3 voices, uma partitura publicada na Studio International em abril de 1969 -- último mês da exposição de Oiticica na Whitechapel Gallery. Nessa obra-partitura, Andre registra três vozes -- para De Kooning, Pollock e Gorky, três expoentes do expressionismo abstrato norte-americano - com palavras comumentemente associadas a cada um deles em textos especializados, numa evidente crítica à falta de voz desses três pintores da geração anterior. Para De Kooning palavras

${ }^{244}$ MCSHINE, Kynaston, Information, Nova Iorque: MOMA, 1970, p. 138. Catálogo da mostra que esteve no MOMA-NY entre julho e setembro de 1970. 
como mulher, rua, sótão, retrato, gotham, etc.; para Pollock, totem, ritual, teia, macho...; para Gorky, retrato, cascata, "beloved", mãe, paisagem...

Em 1967, Sol Lewitt abre um dos primeiros textos a mencionar a palavra “conceitual" com o seguinte sarcasmo: "O editor [de Artforum] me escreveu que é a favor de evitar 'a noção de que o artista é uma espécie de macaco que tem que ser explicado pelo crítico civilizado'. Isso deveria ser uma boa notícia tanto para os artistas quanto para os macacos. Com essa convicção, espero justificar sua confiança(...). Vou me referir ao tipo de arte em que estou envolvido como Arte Conceitual."245

Outro artista emblemático da "arte conceitual", Joseph Kosuth - autor do famoso texto "Art after Philosophy" ${ }^{246}$ publicado na Studio International em 1969 --, também atacou os críticos de arte. O texto apresentado por Kosuth no catálogo da mostra Information (1970) requisita uma nova atuação do artista, que deveria incorporar a função do crítico de arte, profissional que Kosuth trata com desprezo e chama de “middle-man" (intermediário). Segundo Kosuth, o crítico deveria desaparecer e só existiu em certo momento porque a arte do passado estabelecia uma dualidade entre percepção (sentidos) e conceitualização (a reflexão).

Devido à dualidade implícita de percepção e conceitualização na arte passada um intermediário (crítico) pareceu útil. Essa arte [conceitual] tanto anexa as funções do crítico quanto faz o intermediário desnecessário (...) a dependência do artista em relação ao crítico ou escritor de arte para cultivar as implicações conceituais de suas proposições de arte, e argumentar sua explicação, é ou irresponsabilidade intelectual ou o tipo mais ingênuo de misticismo. ${ }^{247}$

${ }^{245}$ LEWITT, Sol. "Parágrafos sobre Arte Conceitual” em Escritos de Artistas: anos 60/70. op.cit., p. 176. Originalmente publicado em LEWITT, Sol. "Paragraphs on Conceptual Art". Artforum. vol. 5, n. 10, 1967, pp. 79-83.

${ }^{246}$ KOSUTH, Joseph. “Art after Philosophy”. Studio International. Primeira parte (v. 178 n. 915 , outubro 1969, p. 134-7); segunda parte (v. 178 n. 916, novembro 1969, p. 160-1); terceira parte (v. 178 n. 917 , dezembro 1969, p. 212-13). No Brasil, a primeira parte do ensaio de Kosuth está traduzida como "Arte depois da Filosofia" em Malasartes, v. 1, 1975, p. 10-13. A edição seguinte de Malasartes traz uma crítica interessante ao texto de Kosuth. cf. GEYERHAHN, Suzana. "A Arte dos Mestres" Malasartes, n. 2 (dezembro de 1975 a fevereiro de 1976), p. 20-1. As três partes do texto de Kosuth estão traduzidas em Escritos de Artistas: Anos 60/70. Glória Ferreira e Cecília Cotrim (orgs.), op. cit.

${ }^{247}$ KOSUTH, Joseph. Information, op.cit., p. 69. tradução da autora. " Because of the implied duality of perception and conception in earlier art a middle-man (critic) appeared useful (..) This art both anexes the functions of the critic and makes a middleman unnecessary (...) an artist's dependence on the critic or writer of art to cultivate the conceptual implications of his art propositions, and argue their explication, is either intellectual irresponsibility or the naivest kind of mysticism." O texto de Kosuth "Art after Philosophy" já havia provocado a ira de críticos de arte. A publicação de "Art after Philosophy” na Studio International criou polêmica nos números seguintes da revista. O tom da discussão é dado, por exemplo, 
O questionamento da "distribuição de tarefas" entre artista e crítico de arte é o único ponto de intersecção indiscutível entre Hélio Oiticica e os dois artistas que estão entre os principais lançadores do termo "conceitual”, LeWitt e Kosuth. Oiticica também defendeu que a crítica fosse feita pelo próprio artista, ou feita ao menos por um críticoartista, envolvido com a obra para além da apreciação visual: "crítico ou é da posição de artista ou não é (...) Quem vive o que você [Lygia Clark] propõe e dá ou vive ou não vive, mas nunca fica numa posição de "assistir" como de fora! Voyeurs da arte! Pior que a pior das inutilidades. ${ }^{248}$

Afora encarnar o "anticrítico" com palavras tão duras quanto golpes de martelo Nietzschianos, Oiticica deixou clara sua distância em relação aos "artistas conceituais"249: "Detesto arte conceitual, nada tenho a ver com arte conceitual. Pelo contrário, meu trabalho é algo concreto, como tal." ${ }^{250}$ A execução do trabalho, para Oiticica, é fundamental, principalmente porque o trabalho acontece justamente na vivência do participador com a obra, posição contrária à opinião de LeWitt de que

na Arte Conceitual, a idéia de conceito é o aspecto mais importante da obra (...) e a execução é um assunto perfunctório. (...) Todos os passos intermediários - rabiscos, rascunhos, desenhos, trabalho malsucedido, modelos, estudos, pensamentos, conversas - interessam. Os passos que mostram o processo de pensamento do artista às vezes são mais interessantes do que o produto final $^{251}$.

pelo comentário irônico de Michel Claura, então colaborador freqüente da Studio International: "Kosuth é um ótimo arquivista. Emerge de seu estudo que a arte conceitual nasceu com ele. Depois, vieram os seguidores, com os quais Kosuth é encorajador e magnânimo [...] Para ajudar aqueles que ainda não entenderam, Kosuth é o líder da Arte Conceitual. Além disso, daqui prá frente, quando quisermos dizer 'Arte Conceitual' deveremos falar "Arte Kosuth"” (cf. CLAURA, Michel, "Conceptual Misconceptions", in Studio international, January 1970, p. 5-6 (tradução da autora). Para uma lista completa das réplicas ao artigo de Kosuth, cf. ALBERRO, Alberto. "Reconsidering Conceptual Art, 1966-1977" in Conceptual Art: a critical anthology, op. cit., p. $\mathrm{xxx}-\mathrm{xxxi}$.

${ }^{248}$ CLARK, Lygia e OITICICA, Hélio. Lygia Clark - Hélio Oiticica: Cartas, 1964-74, op.cit., p. 229 (carta de 11/07/1974).

${ }^{249}$ Para uma discussão sobre a pertinência do termo "conceitual" para a obra de Oiticica, cf. LAGNADO, Lisette., "Os limites do conceitualismo de Oiticica' in op.cit., p. 131-7

${ }^{250}$ Carta a Aracy Amaral, 13/05/1972 apud. LAGNADO, op.cit, p. 135 e AMARAL, Aracy. Arte e Meio Artístico; entre a feijoada e o X-burger. S. Paulo: Nobel, 1983, p. 192.

${ }^{251}$ LEWITT, Sol. "Parágrafos sobre Arte Conceitual" em Escritos de Artistas: anos 60/70 , op.cit., p. 176. Originalmente publicado em Artforum (junho de 1967) 
Apesar de ter deixado maquetes e projetos não realizados em rascunhos perfeitamente organizados, Oiticica enfatizou a importância de executar seus projetos, criar o ambiente ou objeto que iria interagir com um corpo. Os aspectos conceituais do trabalho não se desvinculam da materialidade nem esta daqueles:

Para mim o conceito é uma etapa, como o sensorial, o ambiental, etc. que no fundo são conceitos também; o que acho ruim quando conceito é tratado como objeto-fim artístico, é que passa a ser redundante, fechando-se em si mesmo (...) eu quando faço um projeto é para ser construído mesmo; não me satisfaz o reconhecimento da possibilidade do mesmo $(\ldots)^{252}$

não me interessam 'posições meramente conceituais', como se assumir uma posição confortavelmente intelectual, bastasse: o aspecto fenomenal, que não se resume somente na “ concretização de uma obra" mas no processo explicitante dos problemas propostos, é imprescindível ${ }^{253}$

Outros artistas contemporâneos de Oiticica também criticaram o conceitualismo que se satisfaz sem a execução. No artigo "Beware!” publicado na revista Studio International de março de 1970, Daniel Buren critica certas práticas que o termo "conceitual" favorece, atacando projetos que não se transformam em objetos por dificuldades técnicas ou financeira e que então são "elevados à categoria de 'conceito'”. Buren desaprova nesse texto a "exposição" de "conceitos" em mostras de arte, ou seja, a arte como idéia que gera uma aberração, objetos-conceitos passíveis de participar de uma exposição de arte. Para Buren, essa prática prejudicaria o estudo de uma questão verdadeiramente importante: como livrar-se do objeto. $\mathrm{O}$ artista francês critica ainda o conceitual como discurso - e aqui ele está certamente se referindo a Joseph Kosuth ao dizer que "com uma exibição complacente de academicismo questionável, alguns artistas tentam nos explicar o que arte conceitual seria, poderia ser, ou deveria ser - então gerando um trabalho de arte. Não há falta de vulgaridade nessa pretensão. Estamos testemunhando a transformação de ilusão pictórica em ilusão verbal."254

\footnotetext{
${ }^{252}$ Carta a Aracy Amaral, 13 de maio de 1972. cf. AMARAL, Aracy. Arte e Meio Artístico; entre a feijoada e o X-burger.op.cit., nota de rodapé 8, p. 193.

${ }^{253}$ OITICICA, Hélio. "nyk sept.1,71. Anotações para serem traduzidas para o inglês: para uma próxima publicação", op.cit.
} 
Enquanto Buren preocupava-se com a omissão da "arte conceitual" em lidar com a questão da eliminação do objeto, Oiticica criticava-a por produzir "produtos-obras mais sofisticados" mas que não escapavam dos ditames da sociedade do espetáculo. Para Oiticica, a arte conceitual enfraquecia a discussão sobre a eliminação do espectador passivo por continuar a trabalhar no modelo da arte como produto. Em texto de 1971, Oiticica marca sua distinção em relação aos conceituais:

a colocação do problema de uma atividade-criação onde o espectador no mundo do espetáculo deixe de ser mero espectador e transite de uma posição passiva para a de propositor não resolve de todo o problema da passividade dentro do sistema de espetáculo, do mundoespetáculo: o problema é apenas, como uma transição, colocado em questão: não sei dizer, por estar impregnado dele, se a posta em questão possui ou possuiu a eficácia dialética necessária, além do que foi conquistado no meu próprio trabalho (...) a ligação disso tudo com o que aconteceu e acontece no mundoarte internacional é relativa e sui generis: abortiva: há a tendência compulsiva de "as experiências da posta em questão da problemática espectador-participador" serem transformadas em produtos-obras mais sofisticados, tal como acontece na "gloriosaatuante" arte conceitual (...) esse problema atinge outro maior: ou é o fundamento mesmo dele: a de que toda atividade no mundo ocidental, que "banha o planeta numa visão de mundo" está imersa na sociedade do espetáculo (guy debord): que essas tentativas-experiências [de Oiticica] sejam absorvidas nesse contexto artísticoespetacular (para o qual elas são criticamente, em princípio, e parcialmente dirigidas), parece ser inevitável: o importante é ter em mente que conceitualmente essas tentativas querem colocar em questão, de um golpe, radicalmente, a natureza do criar artístico: querem como que inaugurar não um "modo de ver e sentir" (excessivamente comprometidos de raiz com o espectar) mas o experimental (esse considerado sob um ponto de vista radical), que de sopetão exclui qualquer idéia de um "criar espontâneo" ou de "terapia" já que ambos são objetos eficazes do que se poderia chamar de "criar liberal" da sociedade de consumo (...) desligo-me totalmente de qualquer produto de diluição ou da tentativa de levar o conceito para uma 'saturação consumitiva', que por acaso haja incorporado no brasil (...) não aceitar a compulsividade da diluição como estado definitivo. ${ }^{255}$

${ }^{254}$ BUREN, Daniel. "Beware!", Studio International, Março/1970. Republicado em Conceptual Art: a critical Anthology, op.cit. e em Art in Theory 1900-1990: an Anthology of Critical Ideas, op.cit.. Traduzido para português em Escritos de artistas: anos 60/70. op. cit. (aqui citado em tradução da autora a partir das publicações em inglês).

${ }^{255}$ OITICICA, Hélio. "Notas", 10/06/1971. AHO 0278/71-p1 
É preciso então respeitar a distinção que Oiticica estabelece entre seu próprio trabalho e a "gloriosa-atuante" arte conceitual. Vale lembrar que a participação de Oiticica nas revistas e em Information foi com uma proposta que define bem a distância entre sua obra e a de seus contemporâneos mais voltados ao conceitual: o Crelazer. Ou seja, ainda que inserido numa discussão internacional sobre a redistribuição do trabalho de arte -- envolvendo mudanças nos papéis do artista, crítico e espectador -- e no conflito estabelecido entre a reterritorialização da arte e a arte como produto, Oiticica propõe o inverso do "trabalho" (de arte): lazer. É uma proposta de "des-atuação", de transferência do comportamento frente à arte para o tempo do intransitivo ${ }^{256}$, estratégia para tentar insulá-la do espetáculo e do consumo: mudar do "trabalho de arte" para o "lazer inventivo na arte".

No mês de abril, a revista londrina Art and Artists publica "On the discovery of Creleisure" ${ }^{257}$, de Hélio Oiticica, que relaciona o Éden montado na Whitechapel Gallery com ritos e mitos que "através das épocas foram a manifestação espontânea do crelazer." Na década seguinte, Oiticica passaria pelo que denominou "processo de desmitificação," porém, em 1969, seu Éden busca pelo sublime ${ }^{258} \mathrm{em}$ um labirinto de penetráveis ao qual o artista se refere como "taba". De fato, o catálogo da exposição na Whitechapel Gallery faz alusões ao mito e a sociedades arcaicas, seja em citações de Levi-Strauss, seja em fotografias de casas feitas por povos tribais ${ }^{259}$.

Crelazer confirma o desgosto de Oiticica com a "produção de trabalhos": é a antiarte dos anos 1960 retornando como um "existir anti-arte", ou "ser anti-arte" (expressão

\footnotetext{
${ }^{256}$ Devo o entendimento da radicalidade da proposta de Oiticica ao artigo já citado anteriormente de Celso Favaretto, "Inconformismo estético, inconformismo social, Hélio Oiticica", que aponta "o poder de transgressão do intransitivo".

${ }^{257}$ OITICICA, Hélio. "On the discovery of creleisure". Art and artists, Londres, abril/1969. Em carta para Lygia Clark, Oiticica aponta um erro nesse artigo: "O meu artigo saiu bem, mas com um erro, pois em vez de licit escreveu illicit, em relação à "recuperação dos sentidos", o que é uma burrice e um erro grave; mas vão corrigí-lo no próximo número". ( CLARK, Lygia e OITICICA, Hélio. Lygia Clark - Hélio Oiticica: Cartas, 1964-74 op.cit. 18/04/1969, p. 99). A frase correta, abrindo o segundo parágrafo do texto, é portanto: "The recovery of sensorial desire is a licit one: by the direct senses be able to feel, or crefeel, the body as something that exists and that can master itself." O manuscrito correto está em AHO 0215-68.p. 65 ${ }^{258}$ Sobre o sublime em Hélio Oiticica, cf. AGUILAR, Gonzalo. "Na Selva Branca: o diálogo velado entre Hélio Oiticica e Augusto e Haroldo de Campos" in Fios Soltos: A Arte de Hélio Oiticica, op. cit.

${ }^{259}$ Para uma análise do Éden da Whitechapel Experience como homóloga a estruturas míticas de mudança de modo de ser, cf. VAZ, Suzana, "HO|ME Hélio Oiticica e Mircea Eliade: mitologia radical de padrão iniciático" in Fios Soltos: A Arte de Hélio Oiticica, op. cit.
} 
que Oiticica toma de Décio Pignatari, que por sua vez inspirara-se em Oswald de Andrade ${ }^{260}$ ), em um texto onde pergunta: "como subsistir no mundo do consumismo em que está mergulhada a 'produção artística' em geral? (...) revolução: deveria começar pela tomada de consciência diante das 'imposições culturais' de produção, opondo-se à mecanicidade da mesma e à 'soma de obras' " 261

No mês de abril de 1969, encerramento da Whitechapel Experience, enquanto a Art and Artists publicava o texto de Oiticica sobre o Crelazer, a Studio International trazia um texto-obra de Sol Lewitt que pode ser entendido como denúncia mas também reforço do trabalho não criativo. LeWitt apresenta uma série de instruções para execução de desenhos em parede, associando um número a cada tipo de linha (vertical, horizontal, diagonal, diagonal invertida) e instruções para combinações e permutações do números que, quando re-codificadas para a forma de linhas, originam desenhos nas paredes. Essa decodificação dos números (ou seja, o desenho na parede) poderia ser executada por qualquer "mão", inclusive a de LeWitt, e as instruções reconhecem que as linhas variariam levemente de acordo com a mão que as desenhassem. LeWitt afima em seu texto que "o trabalho é a manifestação de uma idéia e não um objeto". Essa idéia - do artista, é importante ressaltar, -- poderia ser re-executada indefinidamente em várias paredes a partir das instruções. No catálogo Information, a página de LeWitt enfatiza a execução de um desses desenhos de parede como "trabalho" ou "obra" no sentido de desempenho: "dentro de quatro quadrados adjacentes, cada um 4' x 4', quatro artesãos serão empregados a $\$ 4 /$ hora por 4 horas por dia e por 4 dias para desenharem linhas retas de 4 polegadas de comprimento usando quatro lápis coloridos diferentes; 9h preto, vermelho, amarelo e azul. Cada artesão usará a mesma cor ao longo do período de quatro horas, trabalhando num quadrado diferente por dia."

Oiticica apresenta seu trabalho na Art and Artists como "aspiração ao re-turn, ao lazer sem sentido, não o lazer como compensação de horas opressivas" e chama os

\footnotetext{
${ }^{260}$ cf. nota 145

${ }^{261}$ Oiticica, Hélio. "NYK sept.1, 71 Anotações para serem traduzidas para inglês: para uma próxima publicação.", op.cit. Esse texto termina com a transcrição do item 30 de $A$ Sociedade do Espetáculo de Guy Debord. Oiticica transcreve o aforismo em inglês seguido de uma tradução, provavelmente dele mesmo, para o português. cf. DEBORD, Guy. A Sociedade do Espetáculo. Rio de Janeiro: Contraponto, 1997, p. 24.
} 
visitantes a trazerem seus próprios materiais para a construção de ninhos, com um alerta: “é melhor vocês deixarem seus esteticismos em casa porque não há lugar para ele aqui (...) mas sua opção é importante também, incluindo a opção de não participar."

O Crelazer apresentado na Art and Artists e concretizado no Éden da Whitechapel Experience "evolui" na avenida do pensamento de Oiticica e funda o "alémparticipação", a grande questão do artista nos anos 1970. O anúncio dessa nova transformação estava em "The Senses Pointing towards a New Transformation”. 


\subsection{O texto não publicado: "Os sentidos apontando para uma nova transformação"}

A valorização dos sentidos impulsionando uma transformação na arte é a tese principal do texto "The Senses Pointing Towards a New Transformation", que Oiticica enviou no final de 1969 para a Studio International. Oiticica redigiu esse texto em julho de 1969, para ser apresentado no seminário de Arte Táctil, na Califórnia. A boa repercussão da exposição na Whitechapel Gallery (fevereiro a abril/1969) motivou-o a enviá-lo para Studio International em dezembro de 1969, quando Oiticica estava prestes a retornar ao Brasil. O manuscrito do texto traz na capa a anotação: "the text as sent for printing. Studio International 22/12/69." ${ }^{262}$ [O texto como enviado para impressão. Studio International 22/12/69]. Em carta de dezembro de 1969 para Lygia Clark, Oiticica menciona esse texto:

O texto que fiz para o simpósio foi simplificado e corrigido, com ajuda do Guy, e proponho ao Studio International; sairão fotos suas, fantásticas; creio que isso será importante no contexto internacional. O Peter Townsend ${ }^{263}$ me pediu a coisa, e me senti feliz em poder fornecer material tão importante. ${ }^{264}$

Dois meses depois, em fevereiro de 1970, Oiticica está de volta ao Rio de Janeiro, e o assunto retorna: "Guy escreveu dizendo que o Studio International recebeu o artigo, e que vai me escrever; acho que vão mesmo publicá-lo (...) Tomara que saia logo o troço do Studio, porque vai pesar, e muito." ${ }^{265} \mathrm{E}$ as cartas continuam acompanhando o processo

${ }^{262}$ OITICICA, Hélio. “The Senses Pointing towards a New Transformation”, 1969. PHO 0486/69.

Trabalhamos com a versão do texto preparada para envio à Studio International. Este texto foi escrito por Oiticica originalmente para apresentação no simpósio de Arte Táctil, em Long Beach, California (julho de 1969) como indicado pelas quatro outras versões desse texto incluídas no banco de dados "Programa Hélio Oiticica": 1. o manuscrito, de 18 de junho de 1969, que começa dizendo que o texto fora escrito para o simpósio "Touch Art"; 2. sua versão datilografada com indicações à lápis de correções a serem feitas; 3 . uma versão datilografada precedida de folha de rosto manuscrita onde se lê (for Guy - copy with the corrections made) e introdução datilografada "this text was written for the 'Touch Art' Symposium held theis year (july 7/12, 1969) in the California State College, Long Beach (...); 4. uma versão datilografada datada como "London june 18-25 1969"

${ }^{263}$ Peter Townsend foi editor da Studio International entre 1965 e 1975.

${ }^{264}$ CLARK, Lygia e OITICICA, Hélio. Lygia Clark - Hélio Oiticica: Cartas, 1964-74,.op.cit., p. 130 (carta de $23 / 12 / 1969)$

${ }^{265}$ Ibid. p. 138-9 (carta de 19/02/1970) 
de publicação do artigo: "Creio que a coisa do Studio sai em junho ou julho (que demora bem inglesa!)"266 Não saiu, provavelmente por ser um texto extremamente compacto, que condensa, como um bólide, todos os achados conceituais de Oiticica até então. Lê-lo em retrospecto é usufruir do privilégio de apreciá-lo totalmente graças a outros textos do próprio Oiticica e aos escritos de outros artistas-escritores atuantes no final da década de 1960.

Logo no primeiro parágrafo, Oiticica esclarece que sua proposta de elaboração de obras que diminuíssem a ênfase na visão e incluíssem todos os sentidos era muito mais do que uma simples crítica ao esteticismo: era a proposta de abrir a possibilidade da arte influir no comportamento dos indivíduos. Para transformar comportamento, apelar apenas para a visão não seria suficiente. Comportamento e pensamento caminham juntos e pensamento se faz com o corpo todo.

O processo de deslocar o principal foco estético para longe das chamadas artes "visuais" e a introdução, então, dos outros sentidos, não deve ser concentrado ou olhado de um ponto de vista puramente estético; é muito mais profundo; é um processo que, em seu sentido mais extremo, se relaciona e propõe uma possibilidade de novo comportamento descondicionado: a consciência do comportamento como chave fundamental para a evolução dos chamados processos da arte --> a consciência de uma totalidade, da relação indivíduo mundo como uma ação inteira, onde a idéia de valor não está relacionada a um 'foco'específico: o evento esteticista anteriormente tomado como o 'objetivo focal' (...) olfato-visão-paladar-audição e tato misturam-se e são o que MerleauPonty chamou de 'simbólica geral do corpo $^{267}$, onde todas as relações de sentido são estabelecidas em um contexto humano, como um 'corpo' de significações e não a soma de significações apreendidas por canais específicos ${ }^{268}$

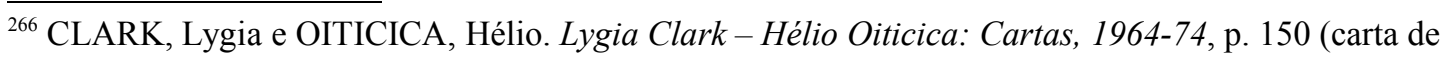
16/05/1970)

${ }^{267}$ cf. MERLEAU-PONTY, Fenomenologia da Percepção. Carlos Alberto Ribeiro de Moura (trad.). São Paulo: Martin Fontes, 2006, p.279-325. (Segunda parte, "O mundo percebido/ O Sentir")

${ }^{268}$ OITICICA, Hélio. "The senses pointing towards a new transformation”, versão de 22/12/1969.( trad. da autora) "The process os shifting the main aesthetic focus away from the so called "visual" arts and the introduction, then, of the other senses, should not be concentrated or looked at from a purely aestheticist point of view; it is much more profound; it is a process which, in its ultimate sense, relates and proposes a new unconditioned behaviour possibility: the consciousness of behavior as a fundamental key to the evolution of the so-called art processes _ $>$ the consciousness of a totality, of the relation individual-world as a whole action, where the idea of value is not only related to a specific 'focus': the aestheticist event taken formerly as the 'focus goal'(...) smell-sight-taste-hearing and touch mingle and are what MerleauPonty once called the "body's general symbolics", where all sense relations are established in a human context, as a " body" of significations and not a sum of significations apprehended by specific channels" 
Oiticica defende essa mudança de comportamento como alavanca para a transformação da arte ("comportamento como chave fundamental para a evolução dos chamados processos da arte" ). E vice-versa. O projeto estético de Oiticica vincula-se a um projeto político: "se a atividade é não-repressiva será política automaticamente"269 Para Hélio o comportamento deveria ser entendido como uma totalidade, em analogia à junção de todos os sentidos em um “'corpo' de significações". ${ }^{270}$ A palavra "síntese”, já comentada no capítulo anterior, aparece com freqüência no texto de Merleau-Ponty que Oiticica menciona em "The Senses poinintg towards a New transformation”, em relação à síntese de todos os sentidos efetuada pelo corpo ao perceber o mundo. Assim como um binóculo une duas imagens monoculares, o corpo sintetiza "imagens" fornecidas por cada sentido $^{271}$. Oiticica estende essa síntese perceptiva a várias áreas do comportamento humano: o social, o político, o estético, etc. Comportamento estético não-repressivo e atividade política fazem parte do mesmo corpo de significações: "a apreensão e a ação não podem ser isoladas, e a idéia analítica dos sentidos vira uma metáfora, também para expressar a complexidade do comportamento humano." ${ }^{272}$

A evolução dos processos artísticos citada em "The Senses pointing...” ("a consciência do comportamento como chave fundamental para a evolução dos chamados processos da arte") - e como visto no capítulo anterior evolução em Oiticica não significa

${ }^{269}$ OITICICA, Hélio. Entrevista em AYALA, Walmir, op. cit., p. 163-166 cf. também FAVARETTO, Celso "Inconformismo estético, inconformismo social: Hélio Oiticica" in Fios Soltos: A Arte de Hélio Oiticica, op. cit.

${ }^{270}$ É interessante notar a semelhança dessa posição de Oiticica de integração de problemas estéticos e políticos com a resposta de Robert Smithson a uma enquete feita pela Artforum com artistas norteamericanos em 1970: qual a sua posição em relação aos tipos de ação política que deveriam ser tomados pelos artistas? A resposta de Smithson também cita uma totalidade na qual o político não pode ser isolado, tudo é parte de um cozido (stew) fervente, tudo se mistura: “o artista não tem que querer uma resposta para a 'crescente crise política na América'. Cedo ou tarde o artista é envolvido ou devorado pela política sem nem mesmo tentar (..) Ação política direta torna-se uma questão de retirar o veneno do cozido que está fervendo." Reproduzido em Art in Theory 1900-1990: an Anthology of Critical Ideas, op.cit. p. 900 ${ }^{271}$ MERLEAU-PONTY, op. cit., p. 314-5. “O objeto intersensorial está para o objeto visual assim como o objeto visual está para as imagens monoculares da diplopia, e na percepção os sentidos comunicam assim como na visão os dois olhos colaboram (...) enquanto meu corpo é não uma soma de órgãos justapostos, mas um sistema sinergético do qual todas as funções são retomadas e ligadas no movimento geral do ser no mundo (...) Meu corpo é a textura comum de todos os objetos e é, pelo menos em relação ao mundo percebido, o instrumento geral de minha 'compreensão'."

${ }^{272}$ OITICICA, Hélio.“ The senses pointing...”, op. Cit. "The apprehension and the action cannot be isolated, and the analytical idea of the senses becomes a metaphor too to express the complexity of human behaviour." 
avanço para frente e sim deslocamento, dança - aqui significa o comportamento transformado em força criativa, a dissolução da "arte" naquilo que é comportamento geral. Essa idéia fica mais clara quando confrontamos esse texto de julho de 1969 com um texto de maio de 1968, apresentado no simpósio do MAM-RJ "Critério para o Julgamento das Obras de Arte Contemporânea", no qual Oiticica afirma a síntese de todos os problemas (estéticos, éticos, políticos, sociais...):

A arte, o conceito de 'obra de arte', todos os problemas que se reduziam às estéticas, que exigiam um sistema próprio de valores no campo do conhecimento humano, caíram, mudaram, houve como que uma súbita diluição numa estrutura maior (...) Trata-se de um problema maior, de ordem universal, onde todos os outros convergem: o social, o político, o ético, em todas as suas implicações (...) A crise dessas formas tradicionais [pintura, escultura, gravura...] se deve a uma transformação profunda que se opera nos critérios fundamentais do fenômeno criador e da necessidade dos artistas criadores, dos pensadores em todos os campos do conhecimento, em procurar um sentido a que eu chamaria de totalidade ou uma realidade total, onde todas as manifestações do homem se interpenetrem, não como uma colagem de experiências de vida, mas que nasça em uníssono com uma totalidade. Esta aspiração coletiva anuncia todas as transformações sociais, políticas, éticomorais que se operam no mundo e as que estão por vir. (...) O que interessa nesse processo universal de transformações, nessa aspiração a uma síntese entre indivíduo e sociedade, entre particular e universal, nessa aspiração a um mundo humano, a uma realidade total, seriam os movimentos que conduzem a um engajamento total nesse processo fantástico irreversível, que absorve tudo (...) O artista, o crítico, o filósofo, o sociólogo seriam propositores - só os que conseguirem essa totalidade poderão propor algo : esse algo baseia-se em tudo o que consistir na procurar de um sentido para a vida nela mesma. ${ }^{273}$

O texto "The senses pointing towards a new transformation" segue para a proposta de transformação do artista. Para Oiticica não basta que apenas o artista caminhe em direção a essa nova experiência com a arte: como foi feito em Éden no Experimento Whitechapel, é preciso também convidar o visitante a "revestir o ninho e fazer uma coberta para si com qualquer material, levando em conta não sua função original, mas

\footnotetext{
${ }^{273}$ OITICICA, Hélio. sem título. O final do manuscrito traz a anotação: "este texto foi lido como contribuição ao debate Critério para o Julgamento das Obras de Arte Contemporânea, realizado no MAM Rio a 23 de maio de 1968". AHO 133.68
} 
apenas o fato de que, para ele, esse material disponha de uma secreta adequação com o ato de morar" 274 .

Claro que a arte do passado sempre tentou de forma metafórica criar, e criou, um novo nível de relações significativas (...) Freqüentemente, então, na maioria das vezes, eu diria, o artista-criador seria o ator-criador, o gerador sublime de forças criativas e recipiente delas, ele mesmo os pólos/postes ${ }^{275}$ do mundo significativo estrutural proposto por suas criações. A grande diferença na nova posição seria que, enquanto os liames anteriores eram totalidades metafóricas-estruturais impostas ao mundo comportamental, os atuais tendem a nascer dele depois de um longo processo de dissolução de "atos do viver humano". ${ }^{276}$

Não interessa para Oiticica o artista que gera e recebe as forças de suas criações, o artista nos dois "pólos" do processo criativo ou que ergue um mundo de significações usando a si mesmo como "estaca" da estrutura. Oiticica quer fundações de vários tipos estruturando seu mundo, uma diversidade de tipos de células compondo um corpo. $\mathrm{Na}$ redefinição de papéis feita por Oiticica, o artista propicia a fundação de um novo espaço de atuação do espectador: ele tanto estará no pólo gerador quanto no pólo receptor e será estaca de sustentação da obra, imagem óbvia no caso das capas parangolé sustentadas e movidas pelo corpo do participador, e que se torna mais sutil à medida em que o pensamento de Oiticica caminha para a idéia de células formadoras de um todo.

Um passo na construção da estrutura da obra a partir de células-participadoras é a dissolução do objeto. A passagem pelo "objeto" deveria ser considerada uma etapa rumo

${ }^{274}$ BRETT, Guy. Brasil Experimental, op.cit., p.39. Esse texto está também reproduzido no fac-símile do catálogo do Experimento Whitechapel em OITICICA, Hélio. Aspiro ao Grande Labirinto, op.cit. e no folheto da exposição "O q Faço é MÚSICA" (Galeria S. Paulo, 1986), mas a versão de 2005, revisada, é mais correta do que essas duas traduções anteriores. Compare, por exemplo a frase de abertura do tópico Éden: " Creio que existe uma premonição desta mudança em um Bólide-Vidro de 1965-6 onde a 'bola de fogo' pode ser formada pelo aglomerado em massa de um material totalmente empalhado: conchas"(trad. de 1980). Na nova tradução, lê-se: "Creio haver uma premonição dessa mudança em um Bólide de vidro de 1965-6, no qual o 'globo de fogo' é formado pela junção do material que existe em todo ele: conchas."

${ }^{275}$ Oiticica usa a palavra "pole" que em inglês quer dizer tanto pólo, extremidade, quanto poste ou estaca de sustentação. A polissemia é adequada, já que o trecho fala tanto de estrutura quanto de geração/recepção de forças.

${ }^{276}$ OITICICA, Hélio. "The Senses Pointing to...” op.cit. "Of course past art always tried in a metaphorical way to create, and did create, a new level of significative relations (...) Often then, mostly I should say, the artist-creator would be the actor-creator, the sublime generator of creative forces and the recipient of them, he himself the poles of the structural significative world proposed by his creations. The great differences in a new position would be that, whereas the former links were metaphorical-structural totalities imposed onto the behavioural world, the actual ones tend to grow from it after a long process of dissolution of 'living human acts'." 
à arte focada no comportamento. $\mathrm{O}$ objeto, diz Oiticica, foi instrumental na dissolução das velhas formas artísticas (pintura, escultura, etc.) mas

a concentração no próprio processo é o começo de uma nova luz (...) a consciência da 'simbólica do corpo' como uma totalidade imediatamente 'na mão' é algo muito mais relacionado ao comportamento mesmo do que a relações objetais; uma relação mais rica que incrementa possibilidades-probabilidades vividas na consciência imediata de 'corpo totalidade' em ação 277

Oiticica então apresenta uma proposta de radicalização da anti-arte: substituir o foco no objeto por uma luz mais difusa que une processo e participador. Brota assim, no pensamento de Oiticica, o "crecomportamento" (crebehaviour): "não uma criação-deobjeto através do comportamento, nem a transformação de atos de vida em atos criativos, o que seria uma idéia simplista: neste caso as condições seriam só Utopias distantes, mas, se [vindos] de dentro do comportamento condicionado, os elementos começam a crescer como necessidades, como germes que explodem do centro mesmo dos conflitos."278 Oiticica quer com o crebehaviour incitar atos de vida que brotem como necessidades, como "germes", a partir de uma situação de conflito de comportamento (comportamento condicionado e comportamento descondicionado). $\mathrm{O}$ indivíduo já conteria esses "germes" que, incitados pela proposição ambiental e sem sair do centro dos conflitos, explodiriam. $^{279}$

\footnotetext{
${ }^{277}$ OITICICA, The Senses pointing... "the concentration on the process itself is a beginning of a new light (...) the consciousness of 'body symbolics' as a totality immediately 'at hand'is something much more related to behavior itself than to objectal relations; a richer relation which increases lived possibilitiesprobabilities in the immediate consciousness of 'body totality' in action;"

${ }^{278}$ A construção dessa frase em inglês dificulta sua interpretação, e após várias leituras optamos por inserir o verbo "vindos" na tradução do original: "not an object-creation through behaviour, nor the transformation of living acts into creative ones, which would be a simplist idea: in such a case the conditions would only become distant Utopias, but, if from inside conditioned behaviour, the elements start to grow as necessities, like germs which burst from the center of the conflicts themselves, the(sic.) and informs behaviour in a new open way, completely at large with individual lived-acts". Marcamos duas palavras em negrito para enfatizar passagens de difícil leitura e interpretação. Oiticica não especifica quais seriam as "condições" ou "elementos". Admitimos que os " elementos" são os atos de vida que surgem como necessidades, como germes, a partir de conflitos de comportamento.

279 A metáfora dos germes que explodem causando uma transformação (naqueles que sobrevivem) e as subsequentes referências de Oiticica a "auto-teatro" e "teatro experimental" nesse mesmo texto sugerem uma aproximação com "O Teatro e a Peste" de Antonin Artaud. Apesar de Oiticica citar passagens de outros textos do ator francês em suas anotações, como "L'ombilic des Limbes", não achamos nenhuma comprovação de que o brasileiro tivesse lido nessa época "O Teatro e a Peste".
} 
O indivíduo passa a ser, assim, sujeito e objeto simultaneamente no ambiente proposto pelo artista: como objeto, o participador é um bólide pronto para explodir em novo comportamento; como sujeito, é ele mesmo quem manipulará as gavetas desse bólide e achará os materiais que estavam escondidos.

A escolha da palavra "germe" não pode ser dissociada da idéia de contaminação: ao explodir, o novo comportamento lançaria esporos do germe em todas as áreas do viver, espalhando uma contaminação transformativa dentro da qual processos da arte e processos de vida tornam-se indistinguíveis. É importante notar que Oiticica escolhe como a "condição" ideal para essa germinação contaminante não uma situação utópica, do indivíduo que se retira de um ambiente alienante para então passar por um processo de transformação. Ao contrário, é da vida como ela é, com o lazer e o trabalho alienados, que surgem as condições para que os germes brotem como "necessidade" e se espalhem no centro do conflito. Oiticica nota que não basta procurar o comportamento descondicionado como um modelo de vida: deve-se aceitar viver numa "consciência contínua desses conflitos" e elege um tipo específico de "conflito" para ser o campo de exploração do crebehaviour: o lazer. $O$ texto passa então de crebehaviour (crecomportamento) a creleisure (crelazer):

em minha evolução, cheguei ao que chamo de crelazer. Para mim o clássico conflito lazer-alienação gerando a idéia de lazer alienado como representado no mundo moderno ocidental seria atacado como conseqüência direta dessa absorção de processos da arte em processos de vida. Crelazer é o lazer não-repressivo, oposto do pensamento do lazer opressivo diversivo. ${ }^{280}$

É preciso refletir sobre a escolha de Oiticica em eleger o "lazer" como o elemento mais adequado para a emergência da consciência da "simbólica do corpo", a consciência do corpo como uma totalidade viva e que determina as relações do indivíduo com o mundo. Concentrar-se no lazer parece ser uma estratégia de Oiticica para tomar posse do tempo, sem a opressão do "lazer diversivo" que determina quando, por quanto tempo e como pausar.

280 " Creleisure is the non-repressive leisure, opposed to diverted opressive leisure thinking." 
Oiticica lia Herbert Marcuse pelo menos desde $1968^{281}$ e as reflexões registradas em Eros e Civilização sobre trabalho e lazer alienados e seus contrapontos, o trabalho e lazer libidinais ${ }^{282}$, foram bem aproveitadas e misturadas com o desgosto de Oiticica com a "produção de obras de arte" ${ }^{283}$. Crelazer seria então um comportamento que toma para si a posse do tempo, processo que ao invés de correr no tempo da produção, corre num tempo-estético, de construção de um mundo próprio, em oposição à aceitação passiva do mundo do espetáculo.

Assim como o branco fora a cor-tempo no início da década, o lazer passa a ser o comportamento-tempo agora: da "cor pura como ação" que orientou a pesquisa de Oiticica no começo da década para o comportamento puro como gesto ${ }^{284}$, isto é, como duração sem finalidade produtivista: lazer. Vale a pena repetir aqui uma citação que usamos na introdução desse trabalho:

Tudo está relacionado com o passado e não está, é claro, inclusive o presente e o futuro; mas, e se lhe disser que não sinto essa relação entre passado-presente-futuro? Então tudo se borra e desaparece, porque quando se vive o crelazer, isso não existe; a grande descoberta do mundo

${ }^{281}$ Em carta para Lygia Clark de 8/11/1968, Oiticica define a atuação artística a partir das teorias de Marcuse: " é nisso que [os artistas] se identificam com o marginal, isto é, com aqueles que exercem atividades marginais ao trabalho produtivo alienante: o trabalho do artista é produtivo, mas no sentido real da produção-produção, criativo, e não alienante como os que existem em geral na sociedade capitalista. Quando digo 'posição à margem' quero algo semelhante a esse conceito marcuseano: não se trata da gratuidade marginal ou de querer ser marginal à força, mas sim colocar no sentido social bem claro a posição do criador, que não só denuncia uma sociedade alienada de si mesma mas propõe, por uma posição permanentemente crítica, a desmistificação dos mitos da classe dominante, das forças de repressão, que além da repressão natural, individual, inerente à psichê de cada um, são a 'mais-repressão' e tudo o que envolve a necessidade da manutenção dessa mais-repressão." cf. CLARK, Lygia e OITICICA, Hélio. Lygia Clark-Hélio Oiticica: Cartas, 1964-74 op.cit., p. 74-75.

${ }^{282}$ MARCUSE, Herbert. Eros e Civilização: uma interpretação filosófica do pensamento de Freud. Rio de Janeiro, LTC, 1999, p. 60. “O controle básico do tempo de ócio é realizado pela própria duração do tempo de trabalho, pela rotina fatigante e pela mecânica do trabalho alienado, o que requer que o lazer seja um relaxamento passivo e uma recuperação de energias para o trabalho. (...) Não se pode deixar o indivíduo sozinho, entregue a si próprio. Pois se tal acontecesse, com o apoio de uma inteligência livre e consciente das potencialidades de libertação da realidade de repressão, a energia libidinal do indivíduo, gerada pelo id, lançar-se-ia contra as suas cada vez mais extrínsecas limitações e esforçar-se-ia por abranger uma cada vez mais vasta área de relações existenciais, assim arrasando o ego da realidade e de seus desempenhos repressivos"

${ }^{283}$ Obra de arte e trabalho no sentido de desempenho, em inglês - idioma em que Oiticica lia várias de suas referências -- são a mesma palavra, work. Assim, a anti-[obra de]-arte pode ser traduzida por "anti-work", anti-trabalho. Aquilo que não é tempo de trabalho é tempo de lazer, e assim a anti-obra (ou anti-arte) é um anti-trabalho, um lazer.

${ }^{284}$ cf. GALARD, Jean. A Beleza do Gesto. São Paulo: EDUSP, 1997. 
atual seria o viver em absoluto, sem a relação velha de tempo cronológico, que é repressiva e cruel. ${ }^{285}$

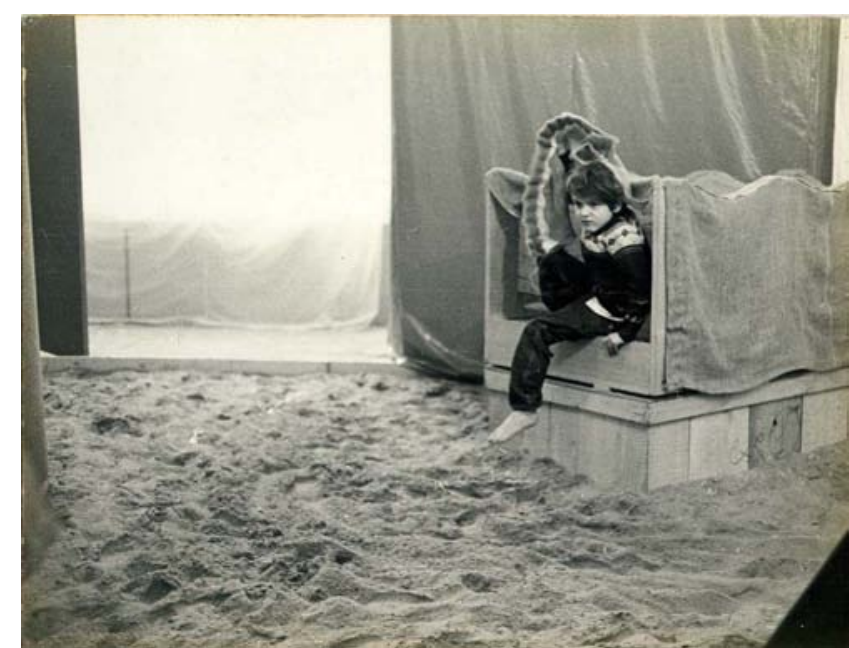

Bólide cama em Éden, Whitechapel Gallery, Londres, 1969. AHO 2118.69-p1

Dentro do Bólide cama de juta ou na tenda preta Cetano-Gil, que integraram o Éden de Whitechapel, o tempo é depurado. Deitado dentro da cama-bólide, o que se percebe não é a imagem e sim a duração de cada um. Não é preciso percorrer o espaço expositivo, não é preciso chegar a nenhum fim, simplesmente estar em contato com a própria duração. "Toda a concepção do Éden se inicia nisso: na transformação de uma síntese imagética, a Tropicália, passando pela formulação do Suprasensorial, até a idéia do crelazer, que teve sua primeira conflagração com a cama-bólide e com os bólide-áreas, feitos desde 1967." Nesses novos bólides, que no lugar de conterem pigmento de cor passam a conter um ser-humano, "deita-se à espera do sol interno, do lazer não repressivo (...) A tenda preta enigmática [Cetano-Gil] concentra o esconder-se, como um ovo(...) nessa tenda preta uma idéia de mundo aspira seu começo: o mundo que se cria no nosso lazer, em torno dele, não como fuga mas como ápice dos desejos humanos"286

\footnotetext{
${ }^{285}$ OITICICA, Hélio. Entrevista em AYALA, Walmir (org.).op.cit., p. 163-6. Rascunho das respostas a Walmir Ayala em AHO 0159.68

${ }^{286}$ OITICICA, Hélio. “As Possibilidades do Crelazer”, 10/05/1969, AHO 0305.69.
} 


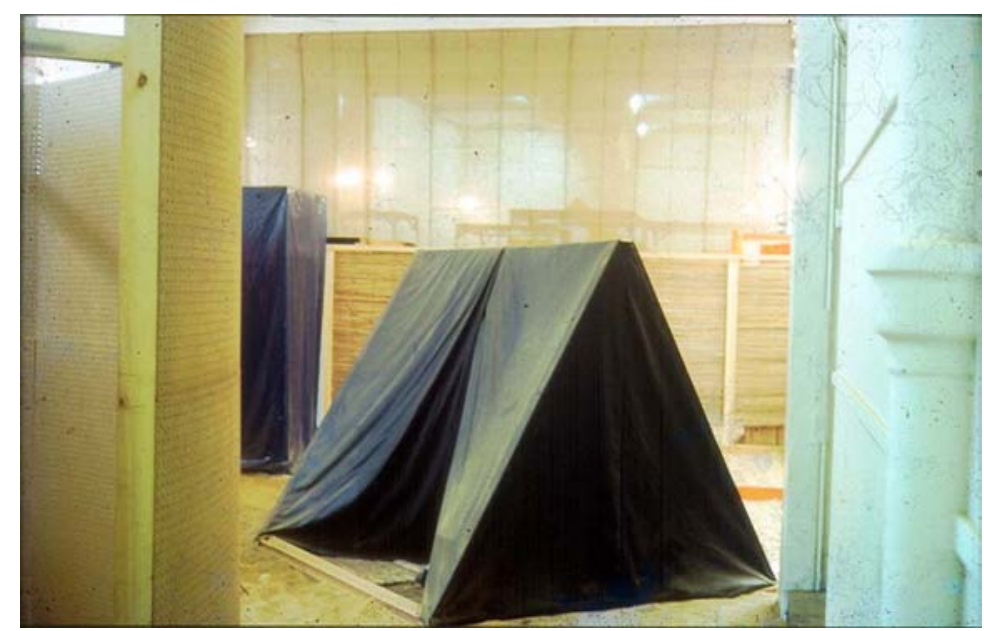

Tenda Caetano e Gil, no Éden. Whitechapel Gallery, Londres, 1969. AHO 1999.69-p7.

Marcuse não é explicitamente citado em "The Senses Pointing...” mas em carta a Lygia Clark discutindo preparativos da viagem e participação de ambos no simpósio de Arte Táctil na Califórnia (onde "The Senses pointing ..." foi apresentado pela primeira vez), Oiticica ressalta para a amiga a confluência entre um trecho de "The senses pointing..." e as idéias de um "livro recente de Marcuse" em que há um capítulo que “propõe uma 'sociedade biológica' como desrepressiva, baseada na comunicação direta em cadeia, o mesmo que pensei e já havia escrito sobre seu problema." E Oiticica, nessa carta, transcreve para Lygia Clark um trecho de "The Senses Pointing...", traduzindo-o para português:

... as experiências mais recentes de Lygia Clark a conduziram para proposições fascinantes, e descobriu que certamente a sua comunicação terá que ser mais uma introdução a uma prática que chama celular de pessoa a pessoa, um diálogo corporal improvisado que se pode expandir numa total cadeia criando como que um todo biológico ou que eu chamaria de creprática. A idéia de criar tais relações está acima da de uma participação simplista como manipulação de objetos: há a procura do que se poderia chamar de ritual biológico, onde as relações interpessoais se enriqueceriam e estabeleceriam uma comunicação de crescimento num nível aberto. Eu digo aqui um nível aberto porque ele não se relaciona a uma comunicação objetal, de sujeito-objeto, mas a uma prática interpessoal que conduz a uma comunicação real aberta: o contato eu-você, rápido, breve como o próprio ato ${ }^{287}$

\footnotetext{
${ }^{287}$ CLARK, Lygia e OITICICA, Hélio. Lygia Clark - Hélio Oiticica: Cartas, 1964-74, op. cit., p. 121 $(27 / 06 / 1969)$
} 
Marcuse, Oiticica e Clark pensavam em células inter-comunicantes, e não simplesmente ligadas a um mesmo centro, o objeto mediador: "eu-objeto-você" substituído pelo "eu-você". Um outro teórico aparecerá mais tarde nas reflexões de Oiticica sobre Crelazer, Guy Debord, que também criticava as redes de relacionamento mediadas. Para Debord, e mais tarde também para Oiticica, o mediador a ser abolido não era exatamente o objeto mas o "espectáculo" e a "mercadoria como espetáculo." Para escrever "The Senses Pointing...", Oiticica talvez ainda não contasse com os aforismos de Debord em seu "repertório de espécimes"288 mas passa a citá-lo a partir de 1970. Oiticica transcreve o aforismo 30 de A Sociedade do Espetáculo em um texto de 1971, mas é no aforismo 29 que Debord descreve uma rede de relacionamentos fraca, cujos nós não se conectam entre si, mas apenas com um centro, que é o objeto espetacular: "o que liga os espectadores é apenas uma ligação irreversível com o próprio centro que os mantém isolados. O espetáculo reúne o separado, mas o reúne como separado."289

Uma das conseqüências de Crelazer, será a semente para proposta de um outro tipo de espetáculo, que Oiticica conclui ser possível ao freqüentar os grandes festivais de rock no final dos anos 1960 e início dos 1970 - Oiticica esteve no festival da Ilha de Wight, que reuniu 150.000 pessoas, e da Ilha de Randall. Ao contrário do consumo rápido de um espetáculo aos quais estamos acostumados quando pensamos em concertos de rock, a experiência a que Oiticica se refere foram eventos que reuniram centenas de milhares de pessoas convivendo durante vários dias. O "show" então incluía, além das bandas, atividades cotidianas de higiene, sono, briga, sexo, alimentação, etc. ${ }^{290}$ É na dança

${ }^{288}$ A menção mais antiga a Debord que localizamos nos textos de Oiticica é um recorte com trecho de $A$ Sociedade do Espetáculo, em inglês, de 1970 (data atribuída pelo Projeto HO a partir da data de outros recortes guardados na mesma pasta). Em manuscritos datados por Hélio Oiticica, Debord aparece a partir de 1971 (como por exmeplo em "Anotações para serem traduzidas para uma próxima publicação", op.cit., de 01/09/1971). O livro La Societé du spetacle fora lançado em novembro de 1967 pela Editora BuchetChastel em Paris, mas foi largamente difundido somente após os acontecimentos de maio de 1968. A redação de "The Senses pointing..." é de junho de 1969.

${ }^{289}$ DEBORD, Guy. A Sociedade do Espetáculo, Rio de Janeiro: Contraponto, 1997. Aforismo 29.

${ }^{290}$ Quando Oiticica se refere a shows de rock, vale a pena ter em mente eventos como os concerto na Ilha de Wight na Inglaterra (cf. OITICICA, Hélio. "Bob Dylan e o 'Environment' Ilha de Wight", 01/09/1969, AHO 457.69), ilha de Randall perto do Harlem (Nova Iorque) (cf. CLARK, Lygia e OITICICA, Hélio. Lygia Clark - Hélio Oiticica: Cartas, 1964-74 op.cit., p. 165 (02/08/1970)) aos quais ele compareceu ou o mais famoso de todos, o Woodstock Festival, que aconteceu entre 15 e 18 de agosto de 1969 em uma enorme fazenda em Bethel, norte de Nova Iorque, reunindo mais de 400.000 pessoas e ao qual Oiticica não 
espontânea com o corpo todo e no coro delirante que acompanha as apresentações de rock que Oiticica acha repertório para a elaboração da proposta do Mundo-Abrigo, uma reunião virtual de inventores sem paredes no tempo ou no espaço, interligados por uma multiplicidade de veios. ${ }^{291}$

foi ("vi o filme, é lindo", diz ele em carta para Clark (cf. CLARK, Lygia e OITICICA, Hélio. Lygia Clark - Hélio Oiticica: Cartas, 1964-74, op.cit. p.165 (02/08/1970)).

${ }^{291}$ A importância do rock na obra de Hélio Oiticica e a proposição "Mundo-Abrigo" serão investigados no capítulo 4. 


\subsection{Escapar da correção do museu: errar pelo mundo}

Após apresentar o conceito de crelazer, Oiticica abre o que podemos considerar uma segunda parte do artigo "The senses pointing...": como desenvolver proposições como Crelazer em um museu ou galeria?

Recentemente, uma nova exigência e importantes decisões me acometeram: na experiência que proponho, como na prática de crelazer. A impossibilidade de "exibir" objetos como parte dessa idéia, em galerias ou museus, tornou-se evidente: tive um vislumbre definitivo disso no experimento Whitechapel em fevereiro-abril de 1969, em Londres. Para mim, aquilo foi mais um experimento do que uma exposição (eu propus coisas ao invés de expô-las). Mas toda a evolução que apresentei lá leva a essa condição: a imposibilidade de experimentos em galerias ou museus - os ao ar-livre ainda poderiam valer, dependendo de suas relações e razões. ${ }^{292}$

Meu sonho secreto, vou dizer aqui: gostaria de colocar uma obra perdida, solta, displicentemente, para ser 'achada' pelos passantes, ficantes e descuidistas, no Campo de Santana, no centro do Rio de Janeiro - é esta a posição ideal de uma obra (... $)^{293}$

Praças, campos abandonados e jardins eram para Oiticica os lugares ideais da arte. Apesar de todas as suas restrições à "crítica de arte" de sua época, Oiticica não dedica muitas linhas à crítica a museus. Sua prática já recusava a instituição como expositora de objetos. A reflexão sobre as instituições de arte aparece junto com o surgimento de Crelazer, mas some depois de 1969: falar em expor peças em museu tornase assunto superado no programa de Oiticica de expansão da arte para o cotidiano. Oiticica tampouco dedica-se a "obras" que sejam uma crítica específica às instituições: a inadequação das instituições aparece como conseqüência de suas proposições, mas nunca como alvo primário, o que ocorre com seus contemporâneos Hans Haacke, Marcel Broodthaers e Daniel Buren, por exemplo. Para o brasileiro, instituições de arte são simplesmente ambientes insuficientes e inadequados para suas proposições: nada mais a dizer. Museu é o mundo ${ }^{294}$ e como o carnaval de Caetano Veloso em "Um Frevo Novo",

${ }^{292}$ OITICICA, Hélio. "The senses pointing towards a new transformation”. op.cit. trad. pela autora.

${ }^{293}$ OITICICA, Hélio. "Programa Ambiental"em___. Aspiro ao Grande Labirinto, op.cit.,p. 79-80.

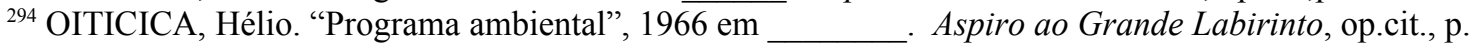
79 
a arte de Oiticica parece dizer: "Todo mundo na praça / Manda a gente sem graça pro salão".

Em um texto de 1968, "A Obra, seu caráter Objetal, o Comportamento" Oiticica aborda a questão da instituição de arte e declara que museus e galerias "muitas vezes traem os sentido profundo, a intenção renovadora do artista." Oiticica refere-se a Mondrian e Schwitters como exemplos de inventores que só poderiam estar em um museu se, ao invés de expostos atrás de vidros, tivessem seus ateliês ou casas, o ambiente de trabalho do artista, transportados para o museu, recriados a partir de fotografias, no que parece ser uma proposta de fazer do museu um livro tridimensional.

Essa proposta é mais complacente em relação a museus do que as opiniões de Joseph Kosuth, por exemplo, que em "Art after Philosophy" confere o mesmo valor a uma pintura de Van Gogh e à paleta de Van Gogh: o valor de serem "curiosidades históricas":

o que uma pintura cubista significava do ponto e vista experimental e conceitual para, digamos, Gertrude Stein, vai além da nossa especulação, porque a mesma pintura "significava", naquela época, algo diferente do que significa agora (...) De fato, os museus preenchem a mesma função da Smithsonian Institution - por que outro motivo o Jeu de Paume ${ }^{295}$, uma ala do Louvre, iria exibir as palhetas de Cézanne e Van Gogh tão orgulhosamente como exibe suas pinturas? ${ }^{296}$

Até Mondrian, diz Oiticica, havia a proposta de criar uma casa-obra baseada mais em "ideação" do que em "fenomenação". O museu ainda poderia reconstituir a casaobra, a proposta de Mondrian de "superpor uma estrutura estética ao cotidiano" ou o "recinto-obra" de Schwitters, que admitia a idéia de um ponto final ou de "parada" no acúmulo de materiais que resultou no Merzbau. ${ }^{297}$

\footnotetext{
${ }^{295}$ O prédio do Jeu de Paume abrigou obras impressionistas de 1947 a 1986. Em 1991 foi reaberto como Galerie Nacionale du Jeu de Paume, um espaço dedicado a arte contemporânea e que de junho a agosto de 1992 abrigou a primeira grande exposição retrospectiva da obra de Hélio Oiticica.

${ }^{296}$ KOSUTH, Joseph, "A Arte depois da Filosofia” em Escritos de Artistas, Ferreira e Cotrim (orgs.) op. cit., p. 218-9.

297 Schwitters, curiosamente, também construiu à sua maneira um "Barracão" - título do grande projeto de Oiticica inventado a partir de Crelazer. No entanto, o barracão de Schwitters era um barracão-obra e não um ambiente de vivência comunitária. Schwitters montou o Merzbarn (barracão Merz) nos arredores de Londres, durante os últimos meses de sua vida, entre 1947 e 1948 (cf. BROOKES, Fred. "Schwitters' Merzbarn”. Studio International, Maio/1969 v. 177 no. 911). Após fugir de Hanover e da Noruega durante a Segunda Guerra, Schwitters foi para Londres e construiu uma versão rural do Merzbau na chácara de um amigo, com fragmentos do entorno. Entre 1965 e 1966 a parede principal do Merzbarn foi removida,
} 
na verdade, Mondrian, e Schwitters com seu Merzbau, propunham a casa-obra como a realização estética da vida, ou seja, a aplicação de uma determinada estrutura, que seria a mais universal possível (ortogonal de Mondrian), levando a um comportamento adequado aí adquirido, ou que fosse o resultado de um comportamento estético na vida (o bricolar coisas achadas fazendo o ambiente no Merzbau de Schwitters) ambos propunham então o Éden, ou seja, apelavam ao prazer de viver esteticamente. ${ }^{298}$

Oiticica detectava claramente diferenças entre seu Éden e as propostas de Mondrian e Schwitters. Os europeus tentaram criar "um mundo-estético, um mundo-arte, superposição de uma estrutura sobre o cotidiano". A proposta de Oiticica era

descobrir os elementos desse cotidiano, do comportamento humano, e transformá-los por suas próprias leis, por proposições abertas, não-condicionadas (...) A obra antiga, peça única, microcosmo, a totalidade de uma idéia-estrutura, transformou-se (...) estruturas palpáveis existem para propor, como abrigos aos significados, não uma 'visão' para o mundo', mas a proposição para a construção do 'seu mundo', com os elementos da sua subjetividade, que encontram aí razões para se manifestar: são levados a isso. ${ }^{299}$

Como poderia a sala de museu conter o que não admite a idéia de resultado nem tampouco de parada daquilo que está in progress? Uma solução, diz Oiticica, seria transformar o "recinto-obra" em "recinto-proposição", substituir a casa-obra pela casatotal e ir além, para uma casa-proposição: Barracão no lugar de museu. O texto de Oiticica parece virtualizar o museu, sugerindo um museu de proposições, sem salas contentores das obras, mas museu-mundo, lugar aberto no espaço, disperso em vários playgrounds para o lazer não alienado.

Ir a esse novo "museu" não mais seria uma distração, mas ao contrário, um exercício para o corpo-comportamento, algo similar à proposta de Antonin Artaud: ir ao teatro como quem vai ao dentista. ${ }^{300}$ Oiticica quer que o participador seja seu próprio

restaurada e instalada em um museu em Newcastle. A descrição do processo de remoção do Merzbarn foi publicada na Studio International em maio de 1969, enquanto Oiticica vivia na Inglaterra. É muito provável que ele tenha lido esse número da revista.

${ }^{298}$ OITICICA, Hélio. "A obra, seu caráter objetal, o comportamento". AHO 160.68 ou . Aspiro ao Grande Labirinto, op.cit. p. 118-122.

${ }^{299}$ Ibid.

300 cf. ARTAUD, Antonin. "O teatro Alfred Jarry" em _.. Linguagem e vida. São Paulo: Perspectiva, 1995 p.31. "O espectador que vem ver-nos sabe que vem oferecer-se a uma operação verdadeira, onde não somente seu espírito mas também seus sentidos e sua carne estão em jogo. Ele irá doravante ao teatro como vai ao cirurgião ou ao dentista. No mesmo estado de espírito, pensando, evidentemente, que não morrerá, mas que é grave e que não sairá lá de dentro intato...Ele deve estar bem persuadido de que somos capazes 
cirurgião, que encontre nos recintos-proposição um fermento para transformação, crescimento que acontece durante o repouso:

\begin{abstract}
Habitar um recinto é mais do que estar nele; é crescer com ele, é dar significado à casca-ovo; é a volta à proposição da casa-total, mas para ser feita pelos participantes que aí encontram os lugares-elementos propostos; o que se pega, se vê e sente, onde deitar para o lazer criador (não o lazer repressivo, dessublimatório, mas o lazer usado como ativante não-repressivo, como crelazer). Então o conceito de casa-total ou recinto-total poder-se-ia substituir pelo de recintoproposição, ou probrecinto. Os 'estados de repouso' seriam invocados como estados vivos nessas proposições, ou melhor, seria posta em cheque a 'dispersão do repouso', que seria transformado em 'alimento' criativo, numa volta à fantasia profunda, ao sonho, ao sono-lazer ou ao lazer-fazer não interessado. ${ }^{301}$
\end{abstract}

Não resistimos a criticar a escolha de palavras de Oiticica nesse texto. O "lazerfazer não interessado" é inteligível no contexto da crítica à ética produtivista e da ditadura do consumo que marca nossa época de confusão entre o ter e o ser. Porém, oferece margem a má interpretação por invocar a famosa definição de Kant de que o belo é aquilo que proporciona "prazer sem interesse", carregada de um ascetismo estranho ao pensamento de Oiticica. O lazer-fazer de que fala Oiticica é muito mais alinhado à "excitação da vontade (do interesse)" de que nos fala Nietzsche em sua crítica à “ingenuidade de um pastor de aldeia” da definição de Kant. ${ }^{302} \mathrm{O}$ lazer-fazer de Crelazer é interessado no descondicionamento, na excitação de todos os sentidos em conjunto, o que se expandiria para a integração dos vários âmbitos que a experiência de vida oferece a cada um. A expansão da arte para o cotidiano é um dos interesses de Crelazer.

Enquanto Oiticica propunha o repouso do Crelazer, a idéia de que "museu é o mundo" teve uma efetivação grandiosamente material - e trabalhosa -- na obra de Robert Smithson ${ }^{303}$ que, assim como Oiticica, freqüentou as páginas da Studio International e do catálogo Information entre 1969 e 1970.

de fazê-lo gritar."

${ }^{301}$ OITICICA, Hélio. "A obra, seu caráter objetal, o comportamento", op. cit.

${ }^{302}$ NIETZSCHE, Friedrich. Genealogia da Moral; uma polêmica. Paulo César de Souza (trad.). São Paulo: Companhia das Letras, 1998, p.93-5. ( Terceira Dissertação, 6).

${ }^{303}$ Para um estudo sobre as aproximações entre Smithson e Oiticica, cf. LAGNADO, Lisette, Hélio Oiticica: O Mapa do Programa Ambiental, op.Cit. p. 154-162. 
Desde 1966, artigos de Robert Smithson sobre suas próprias investigações artísticas e sobre o trabalho de seus contemporâneos (Judd, LeWitt, Dan Flavin, entre outros) apareceram em revistas como a Studio International, Artforum e Arts Magazine. No número de abril de 1969 da Studio International, Robert Smithson propõe um tipo de arte para ser vista em vôos de avião, a "arte aérea": "arte hoje não é mais um adendo à arquitetura, ou um objeto para ser anexado a um prédio depois que ele está acabado, mas sim um envolvimento total com o processo de construção, do chão para cima e do céu para baixo." ${ }^{304}$ Essa proposta foi o resultado do trabalho de Smithson como artistaconsultor em um escritório de arquitetura que participou da concorrência para a construção do Dallas-Fort Worth Regional Airport, no Texas ${ }^{305}$. Segundo os planos de Smithson, o ponto de vista aéreo proporcionaria uma visão não-objetiva do entorno, em oposição ao naturalismo que nos séculos passados predominou na relação entre a arte e a paisagem. Aeroportos seriam construídos, na proposta de Smithson, integrando "museus de arte aérea" a seu entorno, isto é, áreas da paisagem aérea dedicadas a obras de arte. O artigo de Smithson exemplifica como seriam tais obras com projetos de Carl Andre (uma cratera formada pela explosão no solo de uma bomba de uma tonelada jogada de um avião ou um acre de flores azuis, blue-bonnets, símbolo do estado do Texas), Robert Morris (um morro com cerca de 300 metros de raio), Sol LeWitt (um objeto não revelado colocado dentro de um cubo de concreto que seria então enterrado, e portanto invisível aos passageiros de aviões) e uma espiral gigante projetada pelo próprio Smithson, com triângulos de concreto.

A reordenação da paisagem proporcionada por esse museu aéreo implicaria em alterações na percepção de tempo. A dimensão de "duração" seria menos perceptível do que o tempo como catalizador de mudanças drásticas na escala da paisagem à medida em que os aviões decolassem. Daí a proposta de Smithson do "aeroporto como idéia" e não apenas como modo de transporte. Talvez o museu do entorno do aeroporto, com obras em escala que exigem a perspectiva obtida de um avião e o tempo percebido na

${ }^{304}$ SMITHSON "Aerial Art" in Studio International, op. Cit. (trad. da autora). Republicado em Robert Smithson: The Collected Writings. FLAM, Jack (ed.). University of California Press: Berkley and Los Angeles, 1996.

${ }^{305} \mathrm{cf}$. SMITHSON, Robert. The writings of Robert Smithson, op. Cit, p. 5 
velocidade das aeronaves, sensibilizasse os viajantes a enxergarem o resto da paisagem aérea também como arte. Smithson não apenas propõe obras especialmente criadas para o entorno dos aeroportos, mas também valoriza a não-objetividade da paisagem aérea desenhada por estradas e prédios.

A transformação da percepção em relação à paisagem urbana foi também investigada por Oiticica na mesma época em que Smithson propunha o aeroporto como idéia. Ao construir o Bólide lata, Oiticica reflete sobre a possibilidade de alterar a percepção de quem caminha pelas ruas do Rio de Janeiro: "quem viu a lata-fogo isolada como uma obra não poderá deixar de lembrar que é uma 'obra' ao ver, na calada da noite, as outras espalhadas como que sinais cósmicos, simbólicos, pela cidade" ${ }^{306}$ É nesse mesmo texto de 1966, Oiticica afirma "museu é o mundo; é a experiência cotidiana". O mundo de Oiticica é o cotidiano. O mundo de Smithson é o planeta em sua materialidade, o que exige um museu para as possibilidades da nova paisagem advinda de viagens, aeroportos, deslocamentos muito rápidos, expansão na percepção de tempo e de espaço.

Ainda em 1966, Smithson publicou junto com Mel Bochner "The Domain of the Great Bear" ${ }^{" 307}$ (O Domínio da Ursa Maior), descrevendo uma visita a um planetário, "uma concepção artística do inconcebível": um cometa "capturado" exposto em uma sala, uma placa de sinalização indicando "banheiros e sistema solar" e "ilustrações artísticas" de catástrofes em tempos remotos, como por exemplo o desenho de um dinossauro observando um "bólide" - curiosamente essa é a palavra usada na legenda que acompanha a ilustração no texto de Bochner e Smithson, "drawing of dinossaur watching a bolide" 308 .

\footnotetext{
${ }^{306}$ OITICICA, Hélio. Aspiro ao Grande Labirinto, op.cit., p. 80.

${ }^{307}$ SMITHSON, Robert e BOCHNER, Mel. "The Domain of the Great Bear". Art Voices, outono de 1966, republicado em The Writings of Robert Smithson, op. Cit. e em Robert Smithson: The Collected Writings, Op. Cit.

${ }^{308}$ Não podemos deixar de associar o par dinossauro-bólide a uma idéia de extinção e renovação de espécies. O bólide de Oiticica era justamente a inauguração de uma nova ordem de obra: "o contra-bólide revelaria a cada repetição desse programa-obra in progress o caráter de concreção de obra-gênese que comandou a invenção-descoberta do bólide nos idos de 63: por isso era o bólide uma nova ordem de obra e não um simples objeto ou escultura". cf. OITICICA, Hélio. "Devolver a Terra à Terra" (01/01/1980), PHO $123 / 78-2 / 2$
} 


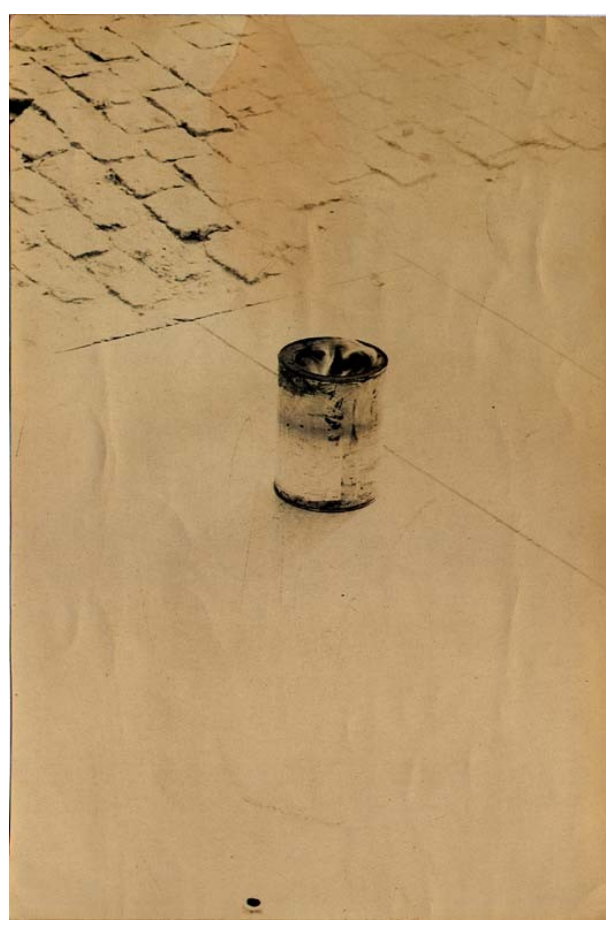

Hélio Oiticica, Bólide lata 1, 1966. AHO 2210

Mais ou menos na mesma época em que Oiticica fazia os bólides com terra, conchas, areia, pigmentos e tecidos, Smithson exibia seus non-sites em galerias de Nova Iorque. Há uma diferença pequena nas datas de criação dos primeiros bólides (por volta de 1963$)^{309}$ e dos primeiros non-sites (1967). Falando em termos exclusivamente formais, bólides e non-sites compartilham uma aparência de recipientes. Os non-sites (nãolugares) eram moldes trapezoidais com fundo mas sem tampa, preenchidos com pedras, terra e gravetos achados pelo artista, dispostos no chão da galeria (que também é um recipiente, disposto no chão do terreno onde foi construída ${ }^{310}$ ) e acompanhados por fotografias aéreas ou mapas topográficos, pendurados na parede como quadros, dos lugares de origem daqueles materiais.

Smithson descreve os non-sites como "recipientes abstratos" que sugerem uma série de inversões, descritas pelo artista: limites abertos versus limites fechados, subtração (do

\footnotetext{
${ }^{309}$ cf. OITICICA, Hélio. "Bólides", 29/10/1963, em Hélio Oiticica. op. cit., p. 66. "Poderia chamar as minhas últimas obras, os Bólides, de 'transobjetos'."

${ }^{310}$ cf. SMITHSON, Robert. "The Spiral Jetty", in The Writings of Robert Smithson Op. Cit p. 115 e Robert Smithson: The Collected Writings, Op. Cit. p.153
} 
lugar) versus adição (ao não-lugar), certeza indeterminada versus incerteza determinada, algum lugar (físico) versus nenhum lugar (abstrato), entre outros. ${ }^{311}$

Em "A Provisional Theory of Non-Sites", de 1968, o artista compara-os a diagramas que substituem o local real. Como um mapa, os non-sites seriam "imagens lógicas" de um lugar, que não se parecem com o lugar real:

Desenhando um diagrama, uma planta baixa para uma casa, um mapa de ruas para a localização de um local, ou um mapa topográfico, desenha-se uma "imagem lógica bi-dimensional". Uma "imagem lógica" difere da imagem natural ou realista no sentido de que ela raramente se parece com a coisa que ela representa. É uma analogia ou metáfora bi-dimensional - A é Z. O Non-Site (um earthwork para áreas cobertas) é uma imagem lógica tri-dimensional que é abstrata, mas ainda representa um local de verdade em N.J. [New Jersey] (As planícies Pine Barrens). É por essa metáfora dimensional que um local pode representar outro local que não se parece com ele - daí o NonSite. ${ }^{312}$

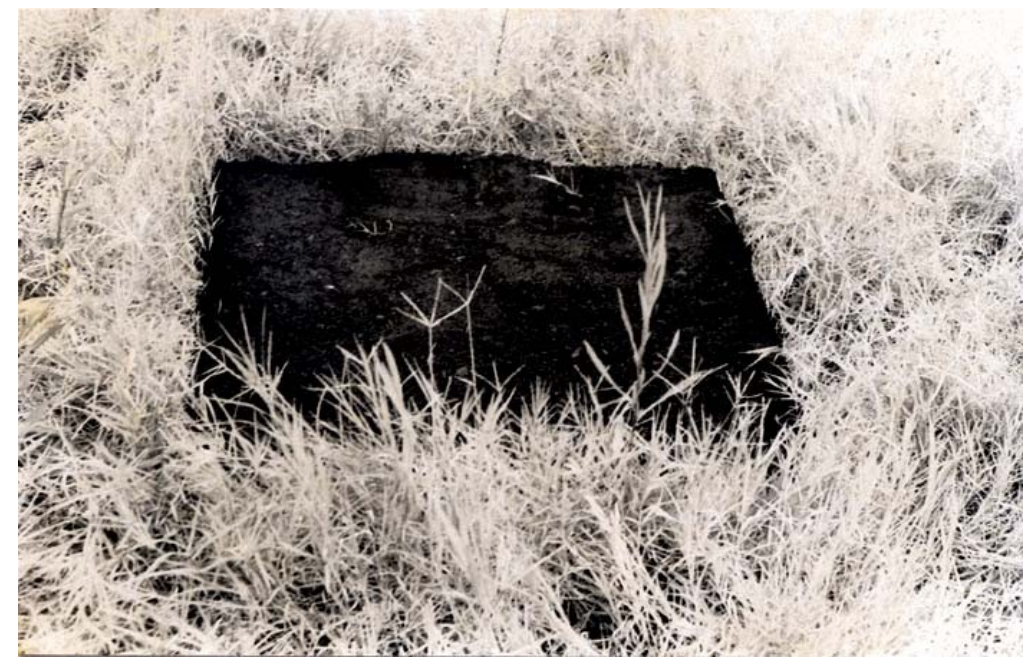

Hélio Oiticica, Devolver a terra à terra, 1979. AHO 522.79-p3

${ }^{311}$ cf. The Writings of Robert Smithson, Op. Cit, p. 115 e Robert Smithson: The Collected Writings, op. Cit. $152-3$

312 cf. Robert Smithson: The Collected Writings, op.cit., p. 364 "By drawing a diagram, a ground plan of a house, a street plan to the location of a site, or a topographic map, one draws a "logical two dimensional picture." A "logical picture" differs from a natural or realistic picture in that it rarely looks like the thing it stands for. It is a two dimensional analogy or metaphor - A is Z. The Non-Site (an indoor earthwork) is a three dimensional logical picture that is abstract, yet it represents an actual site in N.J. (The Pine Barrens Plains). It is by this dimensional metaphor that one site can represent another site which does not resemble it - thus The Non-Site. 


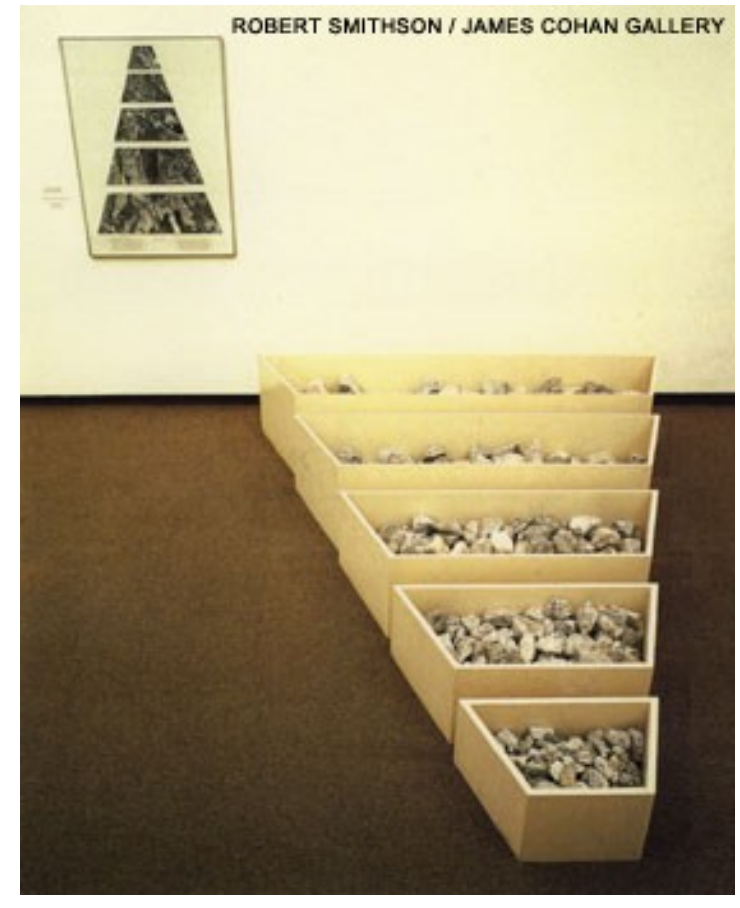

Robert Smithson, A Nonsite, Franklin, New Jersey, 1968 madeira, pedras, fotografias aéreas, $161 / 2^{\prime \prime} \times 82^{\prime \prime} \times 110^{\prime \prime}$

Coleção Museum of Contemporary Art, Chicago

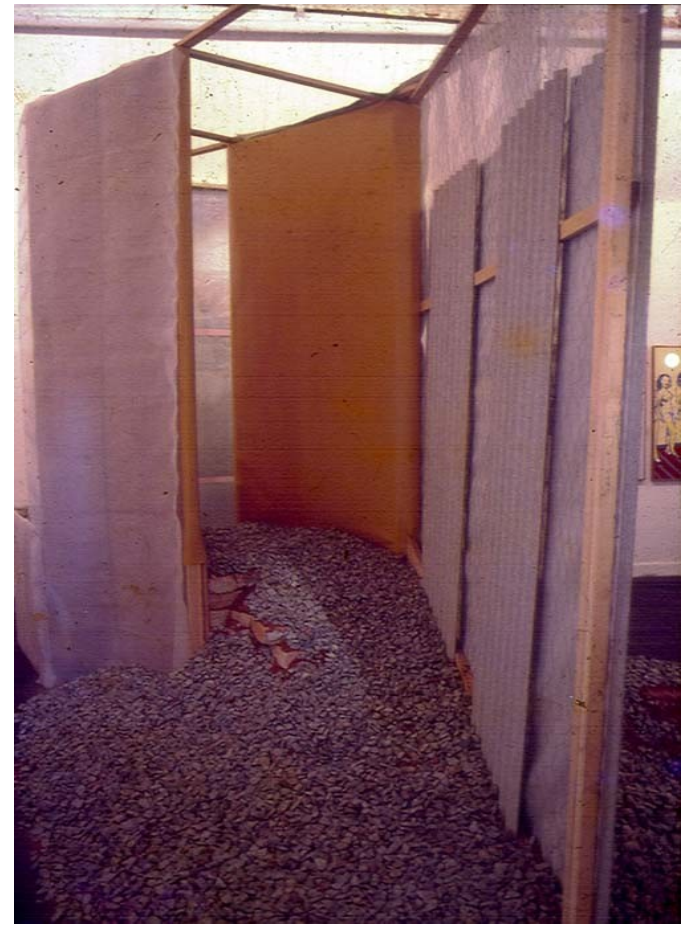

Hélio Oiticica, Penetrável PN28 "Nas quebradas”, 1979 AHO 2161.79.

Os moldes trapezoidais preenchidos por Smithson nos non-sites são formalmente muito semelhantes à moldura que Oiticica usou no contra-bólide Devolver a Terra à Terra, em 1980, já comentado no capítulo anterior, mas o contra-bólide de Oiticica não representa outro local como faz o non-site, nem se contenta em ser um recipiente. Assim como o bólide, o contra-bólide é antes conceptáculo do que receptáculo e "revela a concreção de obra-gênese" ${ }^{\text {"13 }}$. Ao contrário de encapsular, como a palavra "recipiente" (container $^{314}$ ) usada por Smithson sugere, Oiticica quer revelar no contra-bólide o

\footnotetext{
${ }^{313}$ Hélio Oiticica, op. cit., p. 202

314 "the Non-site is a container within another container - the room" cf. Robert Smithson: The Collected Writings, op. Cit. Nota 1, p. 153
} 
processo de expandir energias, intenção anunciada em carta para Lygia Clark de 1969, que já mencionamos no capítulo anterior: "encerrei minha época de fundar coisas, para entrar nessa bem mais complexa de expandir energias, como uma forma de conhecimento 'além da arte'; expansão vital, sem preconceito ou sem querer 'fazer história' etc."’315

O contra-bólide não é container pois não "contém", mas ao contrário, espalha, traz terra para outra terra: a forma resultante do deslocamento de terra, o quadrado preto, se modificará de maneira imprevisível quando a fôrma de madeira for retirada. O penetrável PN28 Nas Quebradas, montado também em 1979, corrobora o sentido de transbordamento de um local em outro. As pedras formam um aclive que conduz a uma moldura aberta e tridimensional, feita com material de construção de barracos. Ao tentar "subir a quebrada", o participador escorrega, afunda nas pedrinhas, mergulhando o corpo na obra, o que faz de "Nas Quebradas" um bólide de dimensão penetrável.

O andar, é a descoberta de que o andar para mim não é só... Quando eu ando ou proponho que as pessoas andem dentro de um penetrável com areia e pedrinhas... eu estou sintetizando a minha experiência da descoberta da rua através do andar... do espaço urbano através do detalhe, do andar... do detalhe síntese do andar... ${ }^{316}$

Ao contrário do non-site de Smithson, o deslocamento e retorno da terra no contrabólide "Devolver a Terra à Terra" ocorre fora da galeria, como uma miniatura das ações que Smithson colocou em prática nos anos seguintes à definição do non-site e que atingiram um ápice com a monumentalidade de Spiral Jetty, de abril de 1970, a espiral gigante feita de pedras e cristais de sal em um lago em Utah, nos Estados Unidos.

Spiral Jetty foi registrado em fotografias publicadas em revistas de arte e em um filme feito por Smithson. Logo após a construção e filmagem essa obra retornou, como o contra-bólide, ao fundo do Great Salt Lake ${ }^{317}$. A monumentalidade de Spiral Jetty

315 A relevância desse trecho de uma carta de Oiticica a Lygia Clark datada de 23/12/1969 já foi anteriormente enfatizada por Lisette Lagnado em seu trabalho 'Mapa do programa ambiental', op.cit., p. 198.

${ }^{316}$ OITICICA, Hélio. Entrevista a Ivan Cardoso, op. cit.

${ }^{317}$ FINEBERG, Jonathan. Art after the 1940s: Strategies of Being. $2^{\text {nd }}$ ed. New Jersey: Prentice Hall, 2000, p. 329. É interessante acrescentar que a partir de 1999, devido a um período de seca em Utah, o Spiral Jetty lentamente reemergiu e o acúmulo de cristais de sal da água, que por mais de duas décadas impregnaram as pedras originalmente pretas usadas na obra, conferiu à espiral uma aparência de neve. cf. cf. SANFORD, Melyssa. "The Salt of the Earth" em http://www.robertsmithson.com/essays/sanford.htm, acessado em 
("tamanho determina um objeto mas escala determina arte" 318 ) e sua condição de relíquia perdida no fundo do lago recoloca a obra na condição dos lugares da arte que interessam a Smithson: a "terra de ninguém", desertos, locais inacessíveis, não explorados e dificilmente exploráveis. A grande dimensão espacial dessa obra é sugerida no filmeregistro por alusões ao tempo de magnitude geológica. $\mathrm{O}$ filme começa com inclusões de imagens de mapas tanto de Utah quanto de continentes do período Jurássico, mostrando os atuais continentes submersos ou em outro arranjo, seguido de um minuto com a história da Terra, cenas de páginas de livros picadas sendo atiradas de um penhasco, desenhos de dinossauros, e outros "elementos disparatados" que passam a "assumir uma coerência"319.

Em Information, aplicando uma estratégia de "deslocamento" que utilizou largamente a partir dos non-sites, Smithson usou a página como lugar de exposição de uma obra também vista por pouquíssimas pessoas, Asphalt Rundown. O catálogo exibe a fotografia de um caminhão despejando asfalto na encosta de uma colina perto de Roma, e o mapa com a legenda "Site of Asphalt Run Down (Cave di Selce)." Esse mapa tem várias camadas de informação cartográficas: curvas de nível do terreno, estradas, linhas pontilhadas, linhas tracejadas, nomes de vilarejos escritos com uma fonte tipográfica rebuscada e um círculo indicando o local da obra de forma muito vaga, abrangendo uma grande área do mapa: achar a obra exige muita disposição para procurá-la na Itália, mas o leitor de Information tem no mapa de múltiplas camadas e na fotografia elementos para criar um não-lugar imaginário.

Hélio Oiticica também explorou percursos mas sem usar mapas no sentido cartográfico. Manhattan Brutalista é um pedaço de asfalto da Av. Presidente Vargas no Rio de Janeiro que tem a forma da ilha de Manhattan, um “objeto-semi-trouvé", posteriormente usado por Oiticica para formar um jardim em seu banheiro, o KyotoGaudi, de $1978^{320}$.

agosto/2007.

${ }^{318}$ SMITHSON, Robert. “The Spiral Jetty”, The writings of Robert Smithson, op. Cit.

${ }^{319}$ ibid, p. 115

${ }^{320}$ Essa menção a Gaudi retorna ao texto de 1968 que anuncia o desprezo de Oiticica pelos museus. Ali em "A obra, seu caráter objetal, o comportamento", Oiticica coloca a arquitetura de fragmentos do catalão ao lado do ready-made de Duchamp na fundação da "construção aberta" de Schwitters. 


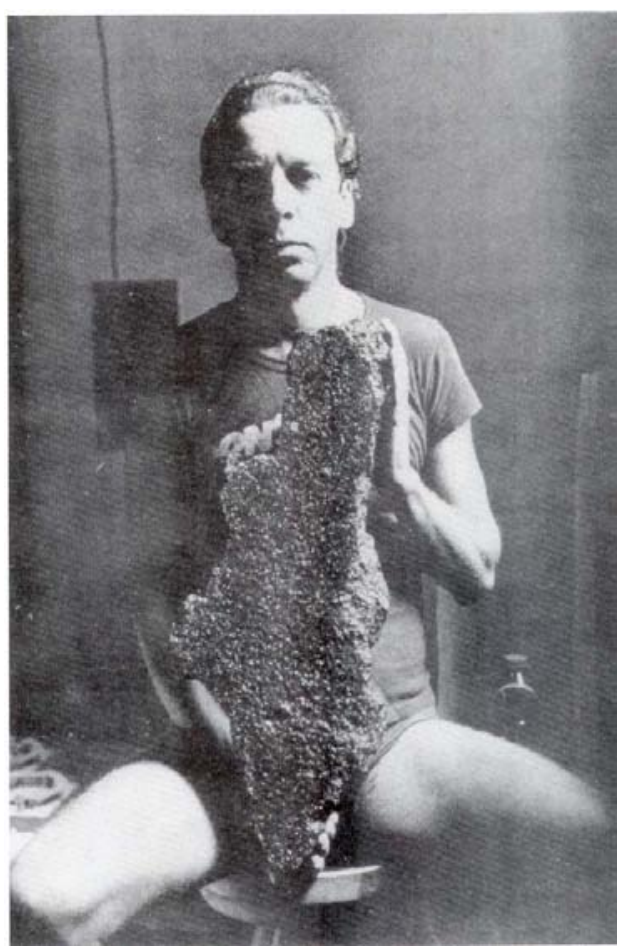

Pedaço de asfalto da Av. Presidente Vargas com a forma da ilha de Manhattan. AHO 2407.89-p13

Em Manhattan Brutalista, Oiticica acha um fragmento da cidade prenhe de significados como conseqüência concreta do errar pelas ruas do Rio de Janeiro. Sua ação como propositor é oferecer a cidade como campo de exploração para caminhantes em um estado de embriaguez criativa que Oiticica denominou de "paixão delirium ambulatorial".

o delirium

ambulatorium é nesse caso a contínua meditação dos momentos transitórios de vida-criação: das aspirações mais carnalmente palpáveis: um desfiar from the bottom of being:

$$
\text { pelo delirium }
$$

ambulatorium é o campo urbano transformado naquilo que L. CLARK chamaria de objeto relacional (será?)

a cidade do RIO DE JANEIRO vai-se transfigurando em campo-meditação: em labirinto topográfico da paixão delirium-ambulatorial! : pelo delirium ambulatorium a meditação é conduzida pelo corpo-pé: é a paixão-meditar-andar q no workshop fermental ${ }^{321}$ gera maqueteslabirintos de topografias criadas: é a mesma paixão q me fez deslocar o campo pictórico do quadro para o espaço e a destruir o pictórico empobrecido de séculos de parede para a proposição de um

\footnotetext{
${ }^{321}$ Há uma palavra nesse ponto do manuscrito escrito em letra cursiva que gera dúvidas mas assumimos que seja "workshop-fermental", e suas outras ocorrências no texto seriam então "workshop-fermento" e "projetos fermentados".
} 
espaço-sítio novo e totalmente aberto à exploração criativa: àquilo q fez MALEVITCH declarar LET REJECTION OF THE OLD WORLD OF ART BE TRACED ON THE PALMS OF YOUR HANDS $^{322}$

Do curador ao ambulatório: Manhattan Brutalista é resultado de uma arte do $\operatorname{ambular}^{323}$. Ambulatório é lugar de passagem curativa, um "curador" que não exige a internação no museu, a fixidez de um mapa. E assim, é fora da instituição e da cartografia, nas ruas como ele as vive, que Oiticica acha, com seus errares ambulatórios, uma comunicação delirante com a cidade, que vai estabelecendo signos novos durante o percurso. Manhattan Brutalista é afinal mapa da ilha de Manhattan ou do Rio de Janeiro? Ou é possível sobrepor todos os mapas formando uma geografia própria?

A paixão delírio-ambulatorial é como o "corpo a corpo amoroso" com a cidade que Michel de Certeau atribui aos que "praticam" o espaço urbano:.324 "É embaixo, ao contrário [da visão aérea], a partir dos limites onde termina a visibilidade, que vivem os praticantes ordinários da cidade. (...) Esses praticantes brincam com os espaços que não são vistos; eles têm um conhecimento tão cego do espaço quanto no corpo a corpo amoroso." $" 325$

De Certeau fala dos praticantes da cidade que a experimentam "embaixo", em oposição ao conhecimento dado por mapas construídos a partir de vistas aéreas. Oiticica acha Manhattan Brutalista nos escombros das obras do metrô. Ainda mais abaixo: a pedra de Manhattan Brutalista vem da escavação subterrânea da avenida por onde na época passavam os desfiles das escolas de samba no carnaval. A intersecção entre o

\footnotetext{
${ }^{322}$ OITICICA, Hélio. "Memorando Caju", 1979, op.cit.

${ }^{323}$ Há errantes famosos nas referências teóricas de Hélio Oiticica, do Zaratustra de Nietzsche ao Guesa de Sousândrade. Ambos percorrem um caminho com subidas e descidas (de montanhas em um; de hemisférios em outro) e incitam uma leitura delirante, que escava significados que possam estar por debaixo de cada frase. É interessante notar o título do último poema de Sousândrade, O Novo Éden (1893). Augusto e Haroldo de Campos informam que essa obra foi descrita pelo poeta como "um curioso labirinto de forma, mas com um pouco de paciência pode-se encontrar o fio de Ariadne do conceito que ele encerra." cf. ReVisão de Sousândrade, op. cit., p. 107.

324 cf. JACQUES, Paola Berenstein. "Parangolés de Oiticica/ Favelas de Kawamata" in Fios Soltos: A Arte de Hélio Oiticica., op. cit, e JACQUES, Paola Berenstein. "Elogio aos Errantes: a arte de se perder na cidade” em Corpos e Cenários Urbanos. JEUDY, Henri e JACQUES, Paola Berenstein (orgs.) Salvador: EDUFBA, 2006.

${ }^{325}$ CERTEAU, Michel de. L'invention du quotidien apud. JACQUES, Paola Berenstein "Elogio aos Errantes" in Corpos e Cenários Urbanos., op. cit.
} 
espaço praticado de um e o delirium ambulatorium de outro é Merleau-Ponty: existem tantos espaços quanto experiências espaciais distintas, diz De Certeau citando a Fenomenologia da Percepção, ${ }^{326}$ livro usado por Oiticica para escrever "The Senses Pointing towards a new Transformation”. Em ambos a idéia de que cada corpo, com sua totalidade perceptiva, constrói um espaço.

A semente do delirium ambulatorium já aparece no texto de 1969 “ The Senses pointing towards a new transformation”, quando Oiticica rejeita a instituição em favor de experiências ao ar-livre. Mas, pouco tempo depois de escrever esse texto, Oiticica participa de Information, num museu. Em carta para Lygia Clark, Hélio justifica sua participação em uma "exposição" e descreve o "Barracão 2" que montaria no MOMANY. "Expor" no sentido de difundir informações sobre as possibilidades da arte é considerado útil para o projeto de Oiticica. Nesse trecho da carta para Lygia, Hélio fala da exposição como se falasse de uma revista, de uma forma de divulgação de seu trabalho, usando o museu não como lugar de acontecimento da obra mas lugar para propagandear informes sobre a obra.

estou trabalhando no show de $\mathrm{Gal}^{327}$ e no filme de Fontoura ${ }^{328}$ (roupas e cenografia); além disso, fiz e mandei os planos para New York (Museu de Arte Moderna) para a exposição Information,

${ }^{326}$ CERTEAU, Michel de. A invenção do Cotidiano: Artes de Fazer. Petrópolis: Vozes, 1999. p. 202. "Merleau-Ponty já distinguia de um espaço "geométrico" ("espacialidade homogênea e isótropa", análoga do nosso [De Certeau] "lugar") uma outra "espacialidade" que denominava "espaço antropológico". Essa distinção tinha a ver com uma problemática diferente, que visava separar da univocidade "geométrica" a experiência de um "fora" dado sob a forma do espaço e para o qual "o espaço é existencial" e a "existência espacial". Essa experiência é relação com o mundo; no sonho e na percepção, e por assim dizer anterior à sua diferenciação, ela exprime 'a mesma estrutura essencial de nosso ser como ser situado em relação a um meio' -- um ser situado por um desejo, indissociável de uma 'direção de existência' e plantado no espaço de uma paisagem. Deste ponto de vista, 'existem tantos espaços quantas experiências espaciais distintas'. A perspectiva é determinada por uma 'fenomenologia' do existir no mundo."

${ }^{327}$ No final do segundo semestre de 1970, Gal lançou o disco "Legal", cuja capa foi projeto de Hélio Oiticica. O show a que Oiticica se refere é provavelmente Deixa Sangrar, que estreou antes do lançamento do disco no Teatro Opinião, no Rio. "Gal surgia acompanhada do grupo Som Imaginário e do percussionista Naná Vasconcellos. O espetáculo se encerrava com o frevo Deixa Sangrar, de Caetano, composto em Londres como paródia ao título do álbum Let it Bleed dos Rolling Stones." cf. http://www.galcosta.com.br

${ }^{328} \mathrm{O}$ filme mencionado é "A cangaceira eletrônica", de Antônio Carlos Fontoura, nunca realizado. O filme mistura a história de Maria Bonita com a cultura de massa dos anos 1970, com cangaceiros invadindo a novíssima Brasília munidos de fuzis e guitarras. Gal Costa faria o papel de Maria Bonita que, "misto de cantora pop e bandida, atirava numa platéia em delírio, com direito a prêmios em eletrodomésticos e viagens para os feridos." cf. RUBIN, Nani. "Hélio Oiticica 'fora de série", $O$ Globo, Segundo Caderno, 11/08/2001. A matéria traz reproduções dos cenários desenhados por Oiticica, e compara-os a penetráveis, labirintos, bilaterais e à Tropicália de 1967. 
para a qual me deram uma sala; achei importante participar disso, se bem que não tenha mais sentido participar em museu ou galeria, mas o que visa a exposição é informar sobre coisas internacionais relacionadas com ambientação, etc.; deram-me uma sala (fui um dos três a ter sala grande; o resto da exposição são filmes e informação escrita) e achei que seria ridículo e pretensioso recusar, uma vez que é loucura pensar que alguém nos States saiba muito a meu respeito; sabe como é lá; enquanto não se aparecec in loco não se existe; e lugar mais central e visceral para aparecer que o MOMA de N.Y. não existe; planejei algo parecido como a coisa que fiz em Sussex, com três andares, tudo ninho para ficar dentro, coberto de aninhagem; são vinte e tantas células; creio que será mais importante que a da Whitechapel. ${ }^{329}$

Um deslocamento na função do museu, ou mistura de papéis, fica explícito na obra apresentada por Vito Acconci em Information. Sua obra consistiu em solicitar à companhia de correio que temporariamente encaminhasse sua correspondência pessoal para o endereço do museu -- serviço que o correio americano presta a cidadãos em mudança de endereço. O título da obra define um papel para o museu: Service Area (área de serviço).

Já que estou num show em museu, posso usar esse show como um serviço. Meu espaço no museu funciona como uma caixa de correio (...) Como minha correspondência está no museu, em exibição, o serviço normal de guarda do museu é usado para evitar uma "ofensa federal" 330 Sua função desloca-se para a de um guarda de correio. (...) Ao ir ao museu, estou atuando num estilo diferente meu papel ordinário de descer para pegar a correspondência. ${ }^{331}$

Acconci aqui usa o museu como parte de um "show", palco para uma performance cujo cerne é justamente alterar a função do museu. Oiticica, ao instalar ninhos no MOMA-NY, usa o espaço expositivo também como um "serviço", porém nem precisa alterar a função desse serviço: é exatamente como vitrine que Oiticica usa o museu, para tornar seu trabalho conhecido em Nova Iorque. Consumir o consumo. ${ }^{332}$

${ }^{329}$ CLARK, Lygia e OITICICA, Hélio. Lygia Clark - Hélio Oiticica: Cartas, 1964-74, op.cit., p. 145 (16/05/1970). No livreto que acompanhou a exposição "Hélio Oiticica e a cena americana" (FERREIRA, Glória. Hélio Oiticica e a Cena Americana. Rio de Janeiro: Centro de Arte Hélio Oiticica, 1998.), Glória Ferreira informa que Oiticica e os outros artistas brasileiros que participaram de Information (Cildo Meirelles, Artur Barrio e Guilherme Vaz) conheceram o curador da mostra do MOMA-NY, Kynaston McShine, durante o Salão da Bússola, no MAM-RJ, em 1969.

${ }^{330}$ Nos Estados Unidos, danificar caixas de correio ou interferir na correspondência de outrem é considerado uma "ofensa federal"

331 Information, op. cit,. p.5

${ }^{332}$ cf. OITICICA, Hélio. "Brasil Diarréia", 1970. op. cit. 
Depois de Crelazer, a instituição não poderia oferecer-lhe nada além disso. Para surpresa de Oiticica, a participação do público acontece: "levaram a Happy Rockfeller para olhar os ninhos. Aí quando abriram tinha um casal trepando lá dentro. Essa foi o máximo que eu já vi, em participação, e foi um escândalo. Ninguém sabia o que fazer." ${ }^{333}$

Décadas mais tarde, comentando sobre a grande sala com os ninhos de Oiticica no MOMA-NY, Vito Acconci descreveu-a como um lugar para as pessoas ficarem, cápsulas, "em uma época em que ninguém pensava em fazer isso, em dar um lugar para as pessoas ficarem". Para Acconci essa montagem dos ninhos revelou uma noção muito interessante de espaço público: junção de vários espaços privados, um composto, e não simplesmente um espaço para um grupo de pessoas: "você pode estar em privacidade e ter uma relação com outras pessoas." ${ }^{334}$ É interessante notar que nos anos 1980 Acconci passou a trabalhar com espaços de interação social e no Arte/Cidade Zona Leste montou o polêmico abrigo no Largo do Glicério, que frustrou-se em rixas entre os habitantes da "vila" transparente de Acconci. O projeto parece ter ficado a meio caminho entre "abrigo" e "palco" (ou circo). A agressividade invasiva e consumista do espetáculo refletiu-se no comportamento dos usuários. ${ }^{335}$

Acconci também não passou desapercebido por Oiticica, que guardou em seus arquivos fotocópias de um texto ${ }^{336}$ sobre a Rubbing Piece, de 1970, performance que começou em um restaurante de Nova Iorque, na qual Acconci esfregava seu braço com os dedos da outra mão até obter uma ferida. A performance não se encerrou no restaurante, já que o braço ferido continuou em transformação (cicatrização, inflamação, etc). O performer é aqui o produtor (da ferida) e consumidor dela. ${ }^{337}$ Nas notas de Oiticica, essa performance é descrita como algo que embaralha papéis, fazendo do corpo uma "performance-event" que abre possibilidades não-representativas para o corpo: "a

\footnotetext{
${ }^{333}$ OITICICA, Hélio in "A última entrevista de Hélio Oiticica”, Jorge Guinle Filho, Interview, abril/1980.

${ }^{334}$ Depoimento de Vito Acconci reproduzido no filme Héliophonia, de 2002, dirigido por Marcos Bonisson e produzido por César Oiticica Filho. Esse depoimento é particularmente interessante no contexto da 27a Bienal de SP, cujo projeto geral de Lisette Lagnado foi inspirado nas propostas de Oiticica e cujo tema, emprestado de Barthes, é justamente "Como Viver Junto".

${ }^{335}$ Para um relato dos eventos envolvendo a vila no Largo do Glicério, cf. TEIXEIRA, Ana. Trocas: A Arte na Rua e a Rua na Arte, dissertação de mestrado, ECA/USP, 2005, p.46-8.

${ }^{336}$ Oiticica guardou fotocópias de algumas páginas de Breakthrough Fictioneers. KOSTELANETZ, Richard (ed.). Barton, Vermont: Something Else Press, 1973.

${ }^{337}$ cf. Arquivo HO, 470.70-p1 a 470.70-p4
} 
multivalência que surge dessa 'piece' sem começo-meio-fim possibilita um scrambling [embaralhamento] dos elementos característicos q fundamentam a obra-atividaderesultado como re-presentação." ${ }^{338}$

A Rubbing Piece impressiona mais Hélio Oiticica do que a obra apresentada em "Information", não comentada nos manuscritos que conhecemos. Em Service Area, Acconci vivencia um estranhamento advindo de uma mudança de hábito: ir ao museu e não à caixa-postal pegar sua correspondência. Há ainda uma atividade "naturalista", mimética do ato de pegar a correspondência, transformada em objeto que continua a ter a mesma antiga função no sistema "artista", "obra", "espectador". Em Rubbing Piece o scrambling (embaralhamento) afeta conceitos cristalizados de "artista", "espectador", "performance". Acconci nessa peça é simultaneamente as três noções, "parodia e contradiz os roles do artista como obreiro." ${ }^{339}$ A experiência de Acconci não poderia ser reduzida a obra ou objeto de representação porque não se concluía em um resultado previamente vislumbrado: as conseqüências dessa peça "se expandem sem limites para regiões do pensamento aberto em aberto." ${ }^{340}$ Para Oiticica, questionar a função da instituição de arte é pouco: ele quer questionar noções "instituídas" de pensamento sobre a arte.

\footnotetext{
${ }^{338}$ OITICICA, Hélio. Ntbk 2/73, p. 85-6

${ }^{339}$ Ibid.

${ }^{340}$ Ibid.
} 


\subsection{Conseqüências de Crelazer: auto-teatro e teatro experimental}

No catálogo de Information, o texto apresentado por Oiticica resume os principais pontos de "The Senses Pointing...", adicionando uma pitada de crítica ao "estado das coisas no Brasil" (e aqui é clara a lucidez da integração que Oiticica faz entre os problemas políticos, sociais e ético-comportamentais: ele critica não a ditadura militar mas sim o estado geral das coisas, estado comportamental num sentido muito amplo, que teve como uma de suas conseqüências a ditadura). A estrutura dos dois textos é a mesma. Depois de apresentar a idéia de crelazer, o texto de Information resume a terceira parte do artigo " The Senses Pointing towards a New Transformation": a proposta de células comunitárias.

É importante que a idéia de ambiente, participação, experimentos sensoriais, etc não sejam limitadas a soluções de objeto; elas devem propor um desenvolvimento de atos de vida e não uma representação a mais (a idéia de "arte"); novas formas de comunicação; a proposição para um novo comportamento descondicionado - meu trabalho levou-me a usar formas acidentais de lazer como elementos diretos a essa abordagem para uma nova abertura (...) é claro que essas são propostas introdutórias para um objetivo muito mais amplo - a atividade total de célula-comunitária. ${ }^{341}$

A "célula comunitária" é uma das conseqüências de Crelazer, e como explicado em "The Senses Pointing towards a New Transformation" surge, a partir da montagem de Éden, vinculada a seu duplo, os "lugares permanentes" (abiding places). Ainda que essas duas propostas já aparecessem em textos de Oiticica anteriores a 1969, é com Éden que o artista articula-as num todo, mencionando-as juntas no texto " As Possibilidades de Crelazer", de 1969.

\footnotetext{
${ }^{341}$ Information, op.cit. p. 103 (trad.da autora): "it's important that the idea of environment, participation, sensorial experiments, etc. be not limited to objectal solutions; they should propose a development of liveacts and not a representation more (the idea of "art"); new forms of communication; the proposition for a new uncondicioned behaviour - my work led me to use forms of accidental leisure as direct elements to this approach to a new opening: from the accidental use of the act (a whole phisical, psychical, etc) of "lying-down", for instance, internal question-situations can arise; possibilities of relating to unconditioned situations-behaviour; of course these are still introductory propositions for a much wider aim -- the total communal-cell activity"
} 
Para o fim, reservo dois núcleos de lazer, no Éden, que a meu ver levam a planos mais avançados, indicam um futuro mais incisivo: 1 - a área aberta ao mito, que se constitui de um cercado circular vedado por uma treliça de duratex (...) a área vazia interior é o campo para a construção total de um espaço significativo "seu" (...) 2 - os ninhos, no fim do Éden, como a saída para o além-ambiente (...) a possibilidade de tudo se criar de células vazias (...) ninho lazer onde a idéia de crelazer promete erguer um mundo onde eu, você, nós, cada qual é a célula-mater. ${ }^{342}$

Argumentaremos que Oiticica imagina o espaço de criação artística - criador é tanto o artista quanto o participador -- como a soma de um espaço interior (ninhos, Barracão) e um espaço externo (labirintos públicos, ruas). Como uma respiração que integra o exalar e o inalar, o projeto ambiental assume nos anos 1970 dois tempos: o extroversor, com as propostas de alcance mais público, ainda que menos intenso, de coletividades atuando em "lugares permanentes" (abiding places) como jardins; e introversor, ou Barracão, que era a concretização das células comunitárias (ou comunidades experimentais).

A idéia de células comunitárias ou comunidades experimentais me ocorreu ao lado da idéia de coletividades de amplo alcance, como a construção de espaços coletivos ou locais permanentes : nas primeiras [células comunitárias ou comunidades experimentais] o grupo privado de células para Crelazer evoluiria em um plano que tenho em mente há muito tempo: o Barracão; ${ }^{343}$

Oiticica talvez estivesse antecipando uma certa tendência de artistas contemporâneos: substituir o "ateliê" pelo "laboratório" e pelo "canteiro de obras" (chantier). O laboratório é, como o Barracão, espaço de experimentação. O chantier, como os jardins e labirintos públicos aspirados por Oiticica, "reaviva o imaginário construtivista e designa um lugar onde as atividades que se desenvolvem têm um caráter coletivo." 344

${ }^{342}$ OITICICA, “As possibilidades de crelazer”. AHO 305.69 (10/05/1969)

${ }^{343}$ OITICICA, "The senses pointing... ", op.cit., traduzido pela autora do original on se lê: "The idea of community cells or of experimental communities came to me side by side with that of wide-spread collectivities, such as the building of collective sites or abiding places: in the first ones [community cells or experimental communities], the creleisure private group cells would be evolved in a plan I have in mind for a long time: the Barracão;"

${ }^{344}$ LAGNADO, Lisette. "Ateliê, Laboratório e Canteiro de Obras" in Folha de S. Paulo, Caderno Mais!, $13 / 01 / 2002$. 
É interessante notar ainda que tanto nas "células comunitárias" quanto nos "lugares permanentes" há referência a um "teatro". Os "lugares permanentes" propiciariam o "auto-teatro", que diluiria divisões de atuação como espectador e performer em um mesmo indivíduo. O Barracão -- nome que as "células comunitárias" recebem em vários textos -- surge de uma proposta de "teatro experimental", uma integração entre prática artística e vivência cotidiana.

\section{Auto-teatro}

. Em agosto de 1968, Oiticica participou com parangolés de Apocalipopótese, no Aterro do Flamengo, em frente ao MAM-RJ e descreveu a experiência como "não a imposição de uma 'idéia estética grupal', mas a experiência do grupo aberto num contato

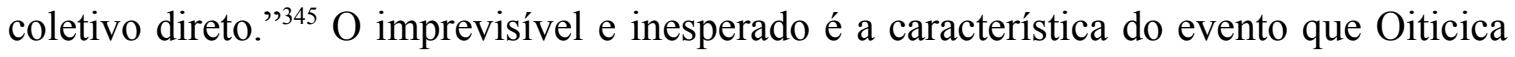
ressalta em texto de 1969, lembrando as Urnas Quentes de Antônio Manuel, os Ovos de Lygia Pape e cães amestrados (Dog's Act) de Rogério Duarte: “Apocalipopótese desvendou-me o futuro; a experiência Whitechapel [de fevereiro a abril de 1969], mais do que uma síntese de toda minha obra ou a soma de idéias, decorre de Apocalipopótese (...) na Apocalipopótese as estruturas tornavam-se gerais, dadas abertas ao comportamento coletivo-casual-momentâneo;";346

A aspiração a um lugar público labiríntico de vivências coletivas permeia os textos de Hélio já no início da década de 1960. Penetráveis, labirintos como o Projeto Cães de Caça e núcleos anunciam essa preocupação com uma arquitetura transformadora de comportamento e construtora de espaços públicos para práticas descondicionadas.

Crelazer detona as propostas para "arquiteturas reais e jardins", labirintos públicos que fugissem do "espetáculo". Os concertos de música, especialmente rock, que nos anos seguintes tanto impressionaram Oiticica amalgamam o ambiente, a música e a performance do público que Oiticica almejava com o auto-teatro.

Em setembro de 1969, Oiticica escreve para Nelson Motta sobre o concerto de Bob Dylan na Ilha de Wight, no sul da Inglaterra:

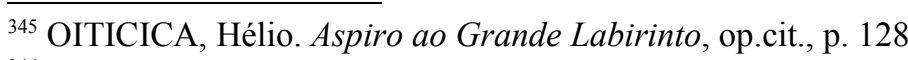

${ }^{346}$ Ibid.
} 
a própria localização do concerto, incluindo a viagem e o local, já é o próprio ambiente e dispensa a idéia de criar um show ambiental; o teatro ali é o mundo (...) as pessoas (..) se encontravam num 'mood' fantástico e parece que a agressividade outrora incentivada por esse tipo de acontecimento cede lugar a uma atitude criativa que em certo sentido se poderia identificar com o que chamo de crelazer. ${ }^{347}$

O auto-teatro é a performance não-espetacularizada e pessoal de cada participador ou explorador dos labirintos que Oiticica passa a propor para espaços públicos, como o “projeto central park" então em desenvolvimento em 1971:

não estou querendo criar obras ou transformar ingenuamente ambientes em obras: a estruturaabrigo-labirinto ou que forma tomar, é o lugar onde proposições abertas devam ocorrer, como uma prática, não-ritualística, o que coloco em comparação como se fora um 'circo sem ritual ou espetáculo', um auto-teatro, onde os papéis estão embaralhados: performer, espectador, ação, nada disso possui lugar ou tempo privilegiado: todas essas tarefas se dão em aberto ao mesmo tempo em lugares diferentes: não há também a urgência de criar nada: a auto-performance de cada um, seria a tarefa-goal que liga tudo. ${ }^{348}$

Aqui a menção a uma prática não-ritualística confirma o descondicionamento comportamental como cerne das conseqüências de Crelazer. O ritual é um modelo fechado, representação de uma macro-percepção do mundo. Oiticica propõe a autoperformance de cada um, no tempo de cada um, e é a estrutura do labirinto que incita esse preechimento virtual do espaço com a subjetividade de cada indivíduo. Aqui, vale lembrar a frase de Lygia Clark: a obra é o molde e ao participador cabe o sopro ${ }^{349}$.

Essa ambientação do auto-teatro dissolve fronteiras entre dois gêneros da arte (arquitetura e teatro) e entre espaço da arte e espaço da vida. No texto de 1969 enviado para a Studio International, Oiticica descreve seus projetos para espaços públicos como estruturas ideais para o "propor propor."

depois disso [Barracão] a idéia de ambiente seria a criação de arquiteturas reais e jardins, locais inventados que poderiam ter um novo sentido (...) Os grandes experimentos coletivos grupais

\footnotetext{
${ }^{347}$ OITICICA, "Bob Dylan e o 'Environment' Ilha de Wight", 01/09/1969

${ }^{348}$ OITICICA, "NYK sept.1, 71 Anotações para serem traduzidas para inglês: para uma próxima publicação". Negrito acrescentado pela autora.

349 "Lygia Clark, da obra ao acontecimento. Somos o molde, a você cabe o sopro" foi o título da exposição de obras de Lygia Clark organizada por Suely Rolnik na Pinacoteca do Estado de S. Paulo em 2006.
} 
deveriam poder contar com lugares permanentes onde experimentos não estariam unidos à idéia de "experimento-espetáculo". Deveria, antes, concentrar-se em uma experiência que propõe crescimento interior: propor propor, que poderia levar a caminhos fascinantes; ou, também importante, construir novas possibilidades de "locais para travessia" (no meu trabalho idéias sobre isso me ocorreram desde 1960, principalmente nos núcleos e penetráveis e projetos para ambientes construídos -- eles sofreram grandes mudanças nesses anos; Eu proponho mais uma "experiência vivencial aberta" do que qualquer coisa que pudesse ser um objeto, que pudesse ainda se atrelar a velhas idéias formais). ${ }^{350}$

"Propor propor" hoje tem cores mais brilhantes do que a já diluída expressão "arte participativa". Guy Brett, que nos anos 1960 percebeu a diferença que artistas como Oiticica e Lygia Clark representavam, também foi dos primeiros a denunciar a participação mecânica e aleatória de certas obras reunidas na categoria "arte participativa", escrevendo em 1969:

'A participação do espectador' possui, como todos os rótulos artísticos, o tom frio das frases fáceis. E já foi friamente posto em prática por alguns artistas. Refiro-me à frieza de todos aqueles objetos e eventos em que a contribuição do espectador é meramente mecânica, em que é apenas recipiente passivo de efeitos preconcebidos ou, de outro modo, de efeitos arbitrários, nos quais não existe potencial para criar relacionamentos. ${ }^{351}$

Oiticica valoriza nessa época as possibilidades de relacionamento entre a obra e cada indivíduo: "Para mim a participação me levou ao 'além-participação'; creio que já superei o 'dar algo' para participar; estou além da 'obra aberta'; prefiro o conceito de Rogério Duarte, de probjeto, no qual o objeto não existe como alvo participativo, mas o

350 OITICICA, Hélio."The Senses pointing towards a new transformation.” Traduzido pela autora do original onde se lê: " after that [Barracão] the idea of environment would be the creation of real architectures and gardens, invented sites which could have a new sense (...) The great collective groupal experiments should be able to count on groupal abiding places, where experiments would not be united to the idea of 'experiment-show'. It should rather concentrate on an internal-growing proposing experience: proposing to propose, which could lead into fascinating ways; or, important also, to build new possibilities of walking through sites (in my work ideas about this came to me since 1960, mainly with the 'nuclei ' and 'penetrables' and projects for built environments -- they suffered great changes throughout those years; I propose much more a 'living open experience' than anything which could be an objectal one, which could still hold on to the old formal ideas)."

${ }^{351}$ BRETT, Guy. "Experimento Whitechapel I" em Brasil Experimental, op.cit., p.33. Também publicado em OITICICA, Hélio. Aspiro ao grande labirinto, op.cit., no fac-símile do catálogo do Experimento Whitechapel . A tradução é melhor na primeira referência. 
'processo' e a 'possibilidade' infinita no processo, a 'proposição' individual em cada possibilidade." 352

No "além-participação", o espectador interessa como possibilidade de invenção infinita pois cada mundo subjetivo provê 'fragmentos' diferentes para a invenção, para a mistura com fragmentos propostos pelo artista-propositor: mundo erigindo mundo inclui os mundos dos participadores. $\mathrm{O}$ artista almejado por Oiticica não reserva apenas para si o título de inventor, mas espalha fragmentos, deixa o participador achar outros fragmentos no mundo, e cria o ambiente onde tudo seja cosido - ou cozido se lembrarmos do caldeirão de Zaratustra ${ }^{353}$-- formando um tecido novo.

Um exemplo de espaço permanente para grandes experiências coletivas é o Magic Square 5 - De Luxe, projeto de 1978 deixado por Hélio em forma de maquete e instruções, construído vinte e dois anos depois no Museu do Açude, no meio da floresta da Tijuca. Apesar de ter sido erguido em uma área relativamente isolada no Rio de Janeiro - bem diferente de locais de passagem aventados por Oiticica para alguns de seus projetos, como o Central Park ou as margens do Tietê em S. Paulo --, Magic Square no. 5 é belamente cercado pela mata que lhe confere algo de ruína-futura, como se deparássemos com um pedaço de arquitetura de uma época que ainda não aconteceu, uma construção que dobra o tempo linear sugerindo o tempo de retorno, cumprindo o que Oiticica esperava de seus labirintos: recriar o espaço real "num espaço virtual estético, e num tempo, que é também estético" ${ }^{1354}$.

\footnotetext{
${ }^{352}$ OITICICA, Hélio. “A Criação Plástica em Questão: Respostas”. PH0 159/68 (dezembro de 1968).

Publicado em A Criação Plástica em questão, op. cit.

${ }^{353}$ Confira o capítulo anterior, seção 2.2 "Construção e acaso"

${ }^{354}$ OITICICA, Hélio. Aspiro ao Grande Labirinto, op.cit. p.29.
} 

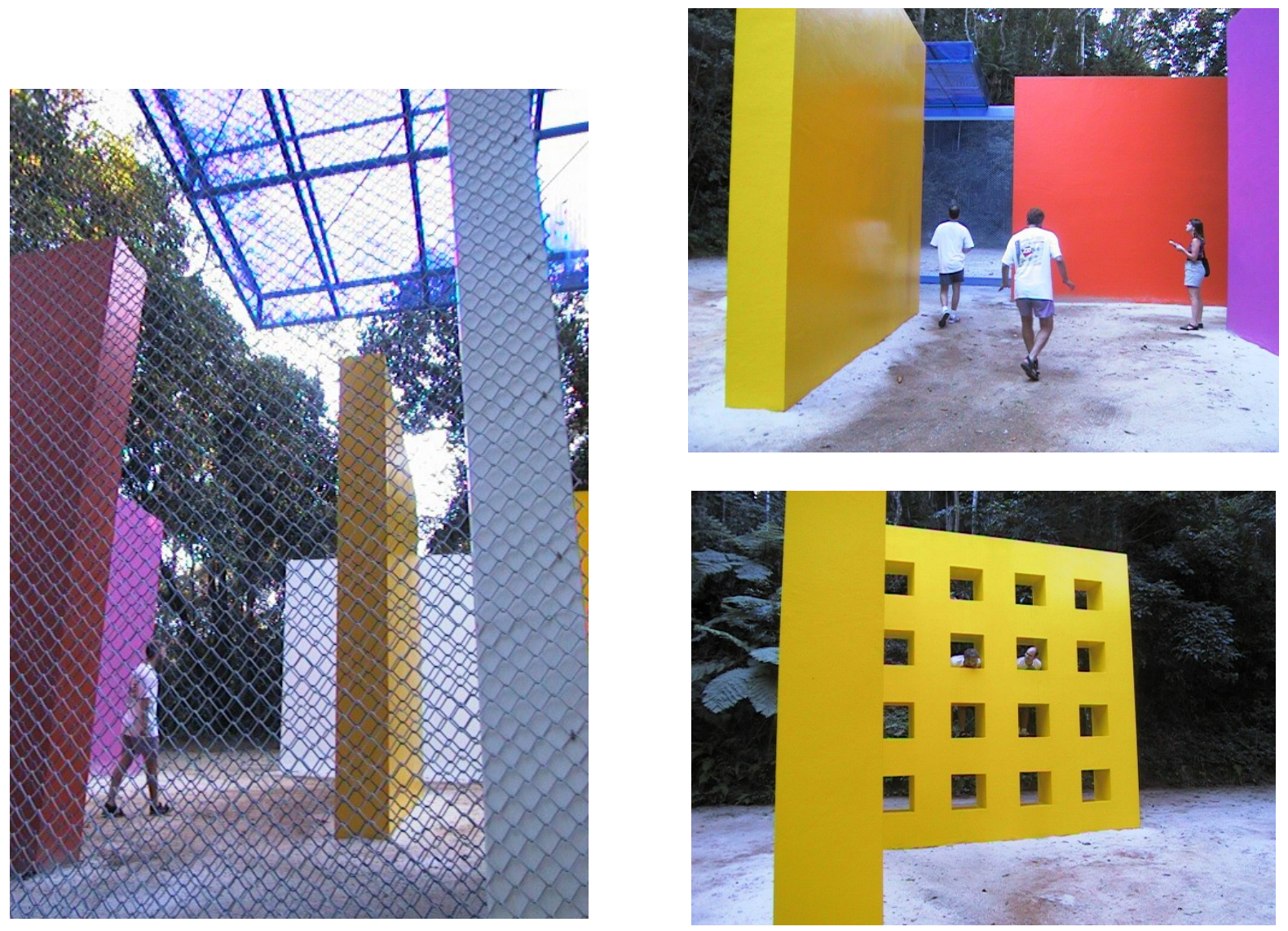

Magic Square no. 5 - De Luxe

Penetrável

9 paredes de alvenaria, $4,5 \mathrm{~m} \times 4,5 \mathrm{~m} \times 0,25 \mathrm{~m}$

tinta acrílica, tela de arame e cobertura com estrutura de metal e acrílico

Projeto 1978/ execução 2000

Coleção Museus Castro Maya

fotos: Paula Braga, 2001.

Magic Square no. 5 embaralha a noção de tempo cronológico: Stonehenge, templo, labirinto, mas também cenário de um jogo, lazer criativo. Os labirintos públicos deveriam criar uma virtualidade ${ }^{355}$, uma ativação de vivências subjetivas, mas não há como negar a pertinência do termo "virtual" aplicado a Magic Square no. 5 no sentido em

${ }^{355}$ O termo "virtualidade" já aparece em carta de 1964 de Oiticica a Lygia Clark: "Você tem razão quando diz que ainda continuam 'compondo' coisas no espaço real - não houve uma recriação da estrutura, mas uma 'deslocação' para o espaço, uma mudança de suportes. Indicam a crise do retângulo figurado do quadro mas se trivializam ao cair no espaço real, sem virtualidade nenhuma. Vedova, por exemplo, que por influência dos seus Bichos resolveu fazer estruturas pintadas no espaço, não faz mais do que repetir o que sempre fez no quadro, só que aqui sem virtualidade, sem força expressiva.”. CLARK, Lygia e OITICICA, Hélio. Lygia Clark - Hélio Oiticica: Cartas, 1964-74, op.cit., p. 21 (01/02/1964). 
que é usado corriqueira e empobrecidamente nesse início do século 21: Magic Square no. 5 tem algo de cenário de jogo virtual. A virtualidade aqui, no entanto, surge do comportamento livre de cada indivíduo, da possibilidade de usufruir de um lazer desprogramado, criativo em um ambiente sem qualquer função pré-determinada. Seria a tradução para português de Magic Squares "praças mágicas" ou "quadrados mágicos"?

Aí eu comecei a fazer um negócio assim de umas maquetes que fossem e pudessem ser uma praça... inclusive eu chamo de "magic square", porque square é quadrado e é praça ao mesmo tempo. Que pudesse ser uma coisa que tá permanentemente ali, para uso do público. ${ }^{356}$

Nesses labirintos, Oiticica retira do plano os quadrados de Maliévitch e Mondrian, transformando-os em praças. O projeto de liberar a arte do quadrado da parede, que Oiticica inicia na década de 1960 a partir de propostas de Mondrian, retorna em outro ponto da curva nos quadrados mágicos do final da década de 1970. A totalidade-obra, intuída por Mondrian e levada pelo neoplasticismo até o ponto da casaobra, do viver esteticamente, é aqui expandido em praça, movimento que Oiticica previra em texto de 1968:

a estrutura-ortogonal [de] Mondrian poderia ser a máter-matriz para a assimilação ambiental do quadro e sua transformação, como também um elemento para a descoberta inicial de um novo contexto para a nova obra-contexto (...) constituindo-se o recinto para experiências abertas ${ }^{357}$

\section{Teatro Experimental}

Um texto escrito em 1968 , "Trama da Terra que Treme: o Sentido de Vanguarda do Grupo Baiano,“ aponta a semente da idéia do Barracão, um grupo, escolhido, de inventores, vivendo comunitariamente o descondicionamento Crelazer. Em "Trama da Terra que Treme...”, de 1968, Oiticica lembra as vaias que Caetano recebera na eliminatória paulista do Festival 68, no TUCA, e o quanto seria benéfico um ambiente de liberdade experimental para as propostas de artistas, músicos e atores brasileiros como Caetano, Gil, Zé Celso, os Mutantes.

\footnotetext{
356 "Um Mito Vadio", entrevista de Hélio Oiticica a Jary Cardoso. Folhetim, 5/11/1978. AHO 944.78.

357 OITICICA, "A obra, seu caráter objetal, o comportamento". AHO 160.68 ou OITICICA, Hélio. Aspiro ao Grande Labirinto, op.cit. p.118-122. Grifo acrescentado pela autora.
} 
Mas, a meu ver o que provoca essa reação [vaias] é justamente o caráter revolucionário implícito nas criações e nas posições do grupo baiano: Caetano e Gil e seus cupinchas põem o dedo na ferida - não são apenas revolucionários esteticistas, não: aliás porque hoje tudo o que revoluciona, o faz de modo geral, estruturalmente, jamais limitado a um esteticismo, e é esse o sentimento implícito do que se convencionou chamar de tropicalismo $(\ldots)^{358}$

Segundo Oiticica, o pleno desenvolvimento dessas novas estruturas totais revolucionárias aconteceriam em um ambiente isolado, segregado mas ainda "dentro" da sociedade, que reunisse as condições para uma grande transformação na criação artística:

Seria urgente e necessário ao grupo a criação de um teatro experimental, ou simplesmente de um recinto onde pudessem fazer experiências com o público, como se fazem pelo mundo afora (...) a solução que é ainda a mais eficaz é essa espécie de nucleização organizada, se bem que expostas sempre à sabotagem, poderão assumir um caráter próprio e terão mais força do que os atos de heroísmo isolados. (...) Daí a necessidade de grupos, a que denomino "comunidades germinativas", de certo modo segregadas 'dentro' da sociedade, (dentro e não fora à espera de dias melhores) dispostas a 'virar a mesa' a qualquer custo (...) É como uma trama que se faz e cresce etapa por etapa: a tramavivência. ${ }^{359}$

"Nucleização organizada", "comunidades germinativas", "uma trama que cresce etapa por etapa" confirmam a importância que a fusão de unidades construtoras assume no pensamento de Oiticica. Na mesma época em que escreve "Trama da Terra que Treme", Oiticica relata em carta a Lygia Clark o prazer de pertencer a essa trama: "de certo modo descobri que não existo só eu mas muitas pessoas inteligentes que pensam e

${ }^{358}$ OITICICA, Hélio. "Trama da terra que Treme (O sentido de Vanguarda do Grupo Baiano)", op.cit. As vaias foram para a música de Caetano E proibido proibir no Festival 68, durante a eliminatória paulista, no TUCA. Caetano reagiu com o famoso discurso em que desafiou a platéia: "é essa a juventude que quer tomar o poder? Se vocês forem em política como são em estética estamos feitos...". O júri do festival classificou a canção para a final, mas desclassificou Questão de Ordem, de Gilberto Gil. Caetano, então, retirou sua composição do festival em solidariedade a Gil e não participou da final no Maracanãzinho. cf. MOTTA, Nelson. Memória Musical. Porto Alegre: Sulina, 1990. Em 1971 Oiticica foi a um show de Gil na New York University e comenta em carta para Augusto de Campos a reação dos brasileiros na platéia: "foi uma droga, pois gil se esforçava para cantar e ser ouvido, enquanto os microfones péssimos não ajudavam e o pessoal fazia uma barulheira incrível; como já era de supor, tratava-se de maioria brasileira (...) há coisas que não valem a pena de serem aceitas; na realidade o tipinho de brasileiro que se encontrava nessa porcaria era o mesmo que quis crucificar gil e cae em s.paulo, naquele festival, aliás no brasil em geral; ora, encontrar essa gente em new york, é demais; e depois, você ainda precisava ver os comentários e conversinhas com gil na cozinha, que servia de bastidores - "Carta de Hélio Oiticica para Augusto de Campos, 16/10/1971, publicada em Fios Soltos: a Arte de Hélio Oiticica, op. cit.

359 ibid. Negrito acrescentado pela autora 
fazem, que querem comunicar, construir. Isso foi bom para quebrar o cerco burguês ou pequeno-burguês em que me encontrava, não por mim mas por uma série de condicionamentos. ${ }^{360}$

Para Oiticica, Rio de Janeiro e Nova Iorque seriam ideais para o Barracão, pois estabeleceriam esse novo tipo de convívio grupal em uma situação experimental e nova, o campo urbano. O convívio comunitário é usualmente associado a utopias idílicas da vida no campo, enquanto que a cidade é vista como o ambiente de células-famílias isoladas.

a idéia do Barracão: ingenuamente e não tanto, formulei como projeto-comunidade pro meu grupo-Rio: mas entenda-se que grupo-Rio e comunidade têm um sentido especial aí: o "grupo" é mutável e não algo como se fora "família" e nem uma representação livre de estrutura familiar: o q é retrógrado e sem saída no isolamento de pessoas/grupos em comunidades é a idéia de q o urbano cria estruturas q são sempre as de família-família, com todos os prejudices, etc: apelam para uma "volta" ao campo como se fora possível começar do zero: mas os problemas de grupo-estrutura família, etc, persistem e em isolamento q termina por criar conflito e boredom e por dissolver com tempo: não são experiências-limite salvo quando situações especiais favorecem: reconhecer o urbano como experimentalmente mais apto a experiências-grupo é bem mais vital: ${ }^{361}$

A idéia do Barracão surgiu também a partir da flexibilidade da arquitetura das casas da Mangueira - espécie de comunidade germinativa -- que não possuíam uma divisão rígida entre cômodos. O Barracão foi concebido em discussões com moradores da Mangueira. O sambista Nildo, diz Oiticica, teve a idéia de criar uma estrutura extensível, com pedaços de madeira como nas favelas, mas feito de forma mais "sólida". O próprio Éden, diz Oiticica, poderia ser estendido para a idéia da casa-total:

não uma extensão estética dentro do espaço cotidiano (como a Merzbau do Schwitters ou o estúdio de Mondrian), não! De certa forma é o contrário disso: as pessoas criariam suas próprias divisões e extensões, seus espaços, de acordo com necessidades de lazer, espaço para reflexão, para ação, para amor (...) um espaço orgânico-vital (...) Com efeito, o Barracão não poderia ter uma estrutura separada própria: dependeria da estrutura do próprio grupo, razão real para sua realização e existência ${ }^{362}$

${ }^{360}$ CLARK, Lygia e OITICICA, Hélio. Lygia Clark-Hélio Oiticica: Cartas, 1964-74, op.cit., p. 44 $(15 / 10 / 1968)$.

${ }^{361}$ OITICICA, Hélio. ntbk 2/73, p. 41

${ }^{362}$ OITICICA, Hélio. "Barracão Idea", 1969. AHO 1664/69 (original em inglês, tradução da autora). 
Oiticica não imaginava apenas um espaço físico de divisões flexíveis - ainda que as descrições de seus apartamentos em Nova Iorque revelem essa característica criada pelas cortinas transparentes e removíveis ${ }^{363}$. Sua proposta de flexibilização no Barracão expandia-se para o comportamento: as atividades produtivas (de lazer ou de trabalho) não estariam divididas rigidamente como cômodos de uma casa, mas sim almejando uma "arquitetura de vida" sem paredes, descondicionada, abolindo diferenças entre momentos de vida prática e momentos de criação. Essa experiência, para Oiticica, conduziria a novas maneiras de compreender o processo de criação ${ }^{364}$. Oiticica cita como experiência similar ao Barracão a vida em comunidade do grupo Exploding Galaxy, em Londres, com quem Oiticica conviveu ${ }^{365}$ e a sala de vivência ("common room") dentro da qual montou os Ninhos na Universidade de Sussex, que eram usados "como refúgio" -- "os ninhos propõem uma idéia de multiplicação, reprodução, crescimento para a comunidade: a proposição do barracão $" 366$.

moradia da FAVELA é o q eu queria como 'algo q não nasce da casa estruturada nos modelos conhecidos': BARRACÃO não seria 'imitar estrutura- espaço do BARRACÃO do morro': isso seria burrice por não possuirmos o tipo de experiência igual à do morador do morro mas semelhante à dele: o q me atraiu então era a não-divisão do BARRACÃO na formalidade da CASA mas a ligação orgânica entre as diversas partes funcionais no espaço interno-externo do mesmo (...) há portanto na minha idéia de BARRACÃO essa exigência inicial sobre espaçoambiente: criar espaço-ambiente-lazer q se coadune a um tipo de atividade q não se fragmente em estruturas pré-condicionadas e q em última instância se aproxime de uma relação corpoambiente cada vez maior -- ${ }^{367}$

Semente desses projetos maiores, os "ninhos" da "experiência whitechapeliana" foram descritos em As Possibilidades do Crelazer, como o "além-ambiente": “é a nãoambientação, a possibilidade de tudo se criar das células vazias, onde se buscaria ${ }^{363}$ Oiticica descreve a flexibilidade de Babylonests e seus ninhos: "mesmo a relação dentro-fora com a rua; sempre a mesma, agora, hoje, mudei: coloquei o cobertor amarelo numa, lençol branco noutra janela: filtros q quebram luz e positividade de dia q começa sol e quente busy". OITICICA, Hélio. ntbk 1/3 p. 0 (zero), 12/jun/1973

${ }^{364}$ OITICICA, Hélio. "Barracão Idea”. AHO 1664/69

365 OITICICA, Hélio. "Experiência Londrina - Subterrânea” (27/01/1970). AHO 0290/70. Apesar de conviver com artistas do grupo Exploding Galaxy, Hélio Oiticica morou apenas 2 ou 3 dias na casa compartilhada pelos membros do grupo, em janeiro de 1969. Agradeço ao Projeto HO por essa informação. 366 ibid.

${ }^{367}$ OITICICA, Hélio. Ntbk 2/73 p. 42. Esse trecho do notebook 2 de 1973 foi datilografado pelo artista para integrar o bloco mundo-abrigo de Newyorkaises. Cf.PHO 194/73 
'aninhar-se', ao sonho da construção de totalidades que se erguem como bolhas de possibilidades (...) onde a idéia de crelazer promete erguer um mundo onde eu, você, nós, cada qual é a célula-máter" ${ }^{368}$.

célula de quê? célula, o que se multiplica no desconhecido, no não formulado, pois como posso formular o comportamento individual? se a célula é aí o "estar no mundo, que é ser, viver"--> vida-mundo-criação, são velhas distinções que são uma célula. ${ }^{369}$

A célula mencionada ao descrever o Barracão e mais genericamente a proposta de Crelazer confere um caráter de organismo vivo à estrutura que em Newyorkaises Oiticica chamaria de 'bloco'. Cada qual um mundo, a junção das células construiria outro mundo. No final dos ano 1960, Oiticica pensa em células por ter em mente uma comunidade de pessoas vivendo juntas. Com Newyorkaises, nos anos 1970, esse sonho desloca-se para uma reunião menos corpórea de inventores. Newyorkaises é um Barracão virtual, onde juntos estiveram Nietzsche, Cage, Debord, Mallarmé, Burroughs, numa flexibilidade não só arquitetônica ou comportamental, mas também temporal. Oiticica chega a juntar as palavras Babylon e Barracão no termo "Barnbilônia""370.

Conhecemos os grandes blocos de Newyorkaises, mas ao tentarmos reconstruí-lo, como que para deixá-lo pronto para publicação, perdemo-nos, pois ele também é um labirinto, que cria um tempo virtual e mágico de convivência de várias célula-maters.

\footnotetext{
${ }^{368}$ OITICICA, Hélio. "As possibilidades do crelazer", em Hélio Oiticica, op.cit., p. 136

${ }^{369}$ OITICICA, Hélio. sem título, PHO 0384/69. Publicado como "LDN" (abreviação de "London") em OITICICA, Hélio. Aspiro ao Grande Labirinto, op.cit., p. 117

370 cf. CLARK, Lygia e OITICICA, Hélio. Lygia Clark - Hélio Oiticica: Cartas, 1964-74, op. cit., p. 219 $(24 / 01 / 1972)$
} 


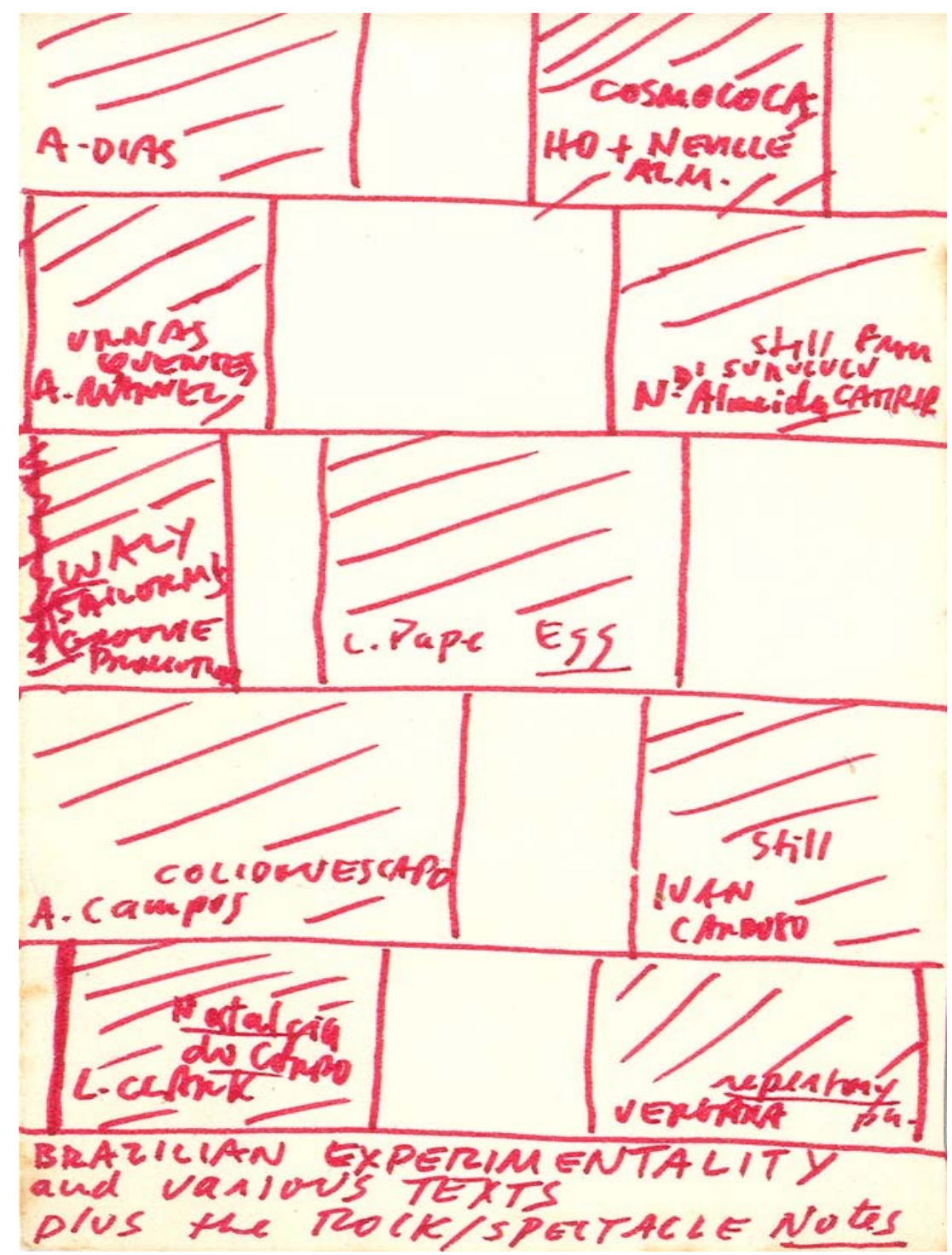

Hélio Oiticica, rascunho sem data, provavelmente feito para ser capa de uma pasta de anotações, com a frase "Brazilian experimentality and various texts plus the rock/spectacle notes" e menções -organizadas em forma de blocos, semelhantes aos de "ready-constructible" -- a obras de Antônio Dias, Antônio Manuel, Hélio Oiticica, Neville D'Almeida, Waly Salomão, Lygia Pape, Augusto de Campos, Ivan Granato, Lygia Clark e Carlos Vergara. AHO 1364.sd 


\section{Do Barracão ao Mundo-Abrigo}

Mangueira

Teu cenário é uma beleza

Que a natureza criou...

Vista assim do alto

Mais parece um céu no chão

Sei lá

Em Mangueira a poesia

Feito um mar se alastrou

E a beleza do lugar

Pra se entender

Tem que se achar

Que a vida não é só isso que se vê

É um pouco mais

Que os olhos não conseguem perceber

$\mathrm{E}$ as mãos não ousam tocar

E os pés recusam pisar

Sei lá, não sei

Sei lá, não sei

Não sei se toda a beleza

De que lhes falo

Sai tão somente de meu coração

Em Mangueira a poesia

Num sobe-desce constante

Anda descalça ensinando

Um modo novo da gente viver

De pensar e sonhar, de sofrer

Sei lá não sei

Sei lá não sei não

A Mangueira é tão grande

Que nem cabe explicação

(Paulinho da Viola e

Hermínio Bello de Carvalho, 1968)
Oh, a storm is threat'ning

My very life today

If I don't get some shelter

Oh yeah, I'm gonna fade away

War, children, it's just a shot away

It's just a shot away

War, children, it's just a shot away

It's just a shot away

Ooh, see the fire is sweepin'

Our very street today

Burns like a red coal carpet

Mad bull lost its way

War, children, it's just a shot away

It's just a shot away

War, children, it's just a shot away

It's just a shot away

Rape, murder!

It's just a shot away

It's just a shot away

(...)

The flood is threat'ning

My very life today

Gimme, gimme shelter

Or I'm gonna fade away

War, children, it's just a shot away

It's just a shot away (...)

I tell you love, sister, it's just a kiss away

It's just a kiss away

(...) Kiss away, kiss away

(The Rolling Stones, 1969) 
Os últimos textos escritos por Hélio Oiticica enfatizam o movimento de “desmitificação” pelo qual sua obra passara na década de 1970. O artista repete também em textos e entrevistas que tudo o que até então fizera fora prelúdio ao que ainda viria e insiste na relevância do "inventor." Desmitificação, prelúdio ao novo e inventor são três noções que Oiticica sintetiza na idéia de surgimento do "artista trágico," mencionado no texto "O q Faço é MÚSICA" de 1979.

As sucessivas sínteses que Oiticica detona em direção ao além-da-arte desde a pesquisa sobre a cor na década de 1950 até o prelúdio ao novo terminam em uma nota sensível, aquela que não conclui confortavelmente a melodia, suspensão incômoda que pode seguir para múltiplas conseqüências. A MÚSICA continua, assim, com seu caráter "in progress."

\subsection{Mitificação}

A "vontade por um novo mito" é uma das "bases fundamentais para definição do parangolé." ${ }^{371}$ No texto "Como cheguei à Mangueira", Oiticica descreve seu contato inicial com o samba e seu desejo de "participar do samba, do seu ritmo, do seu mito". Nesse relato, escrito em meados dos anos 1960, e no qual ainda se denomina "jovem pintor", Oiticica revela que retribuía as aulas de samba que recebia de seus amigos da Mangueira com aulas de pintura, e ressalta os aspectos arcaicos e míticos que encontrou no morro:

[T]oda a minha evolução artística caminha para o que eu chamo de "expressão mítica" essencial na arte. A Mangueira para mim é como se existisse há dois mil anos: como expressão o seu samba possui algo de arcaico, como se nascesse da terra; não me impressiona tanto a "tradição" mas sim o arcaísmo que contém a sua expressão. Na sua maneira de ser, há algo que nos leva à origem das coisas (...) A criação do Parangolé nasce dessa necessidade do que chamo "nivelamento cultural"; é uma aproximação da arte com seu elemento mítico. ${ }^{372}$

371 OITICICA, Hélio. "Bases Fundamentais para uma definição do Parangolé", 1964, em Aspiro ao Grande Labirinto, op.cit., p.68 ou AHO 35.64-p4.

372 OITICICA, Hélio "Como cheguei a Mangueira", sem data, AHO e PHO 1863/sd. O texto foi escrito depois da invenção do parangolé, portanto depois de 1964. 
Oiticica sente o samba vindo "debaixo do barro do chão"373 como se estivesse em coro com a letra que Gilberto Gil comporia anos mais tarde sobre o baião. Ao procurar a "origem das coisas" em uma Mangueira que parecia existir "há dois mil anos", Oiticica constrói um mito-abrigo que sintetiza - inaugura outro ponto de recomeço - suas experiências construtivistas até então concretizadas em núcleos, penetráveis e bólides. $\mathrm{O}$ corpo que sobe o morro, caminha pelas quebradas e pisa um chão de pedras entranha aquele corpo que até então aparecia nos textos de Oiticica como aparato sensorial a ser afetado pela cor. É como se o corpo, depois da Mangueira, estivesse recheado do ambiente do morro, encorpado, a ponto de ser parte do ambiente.

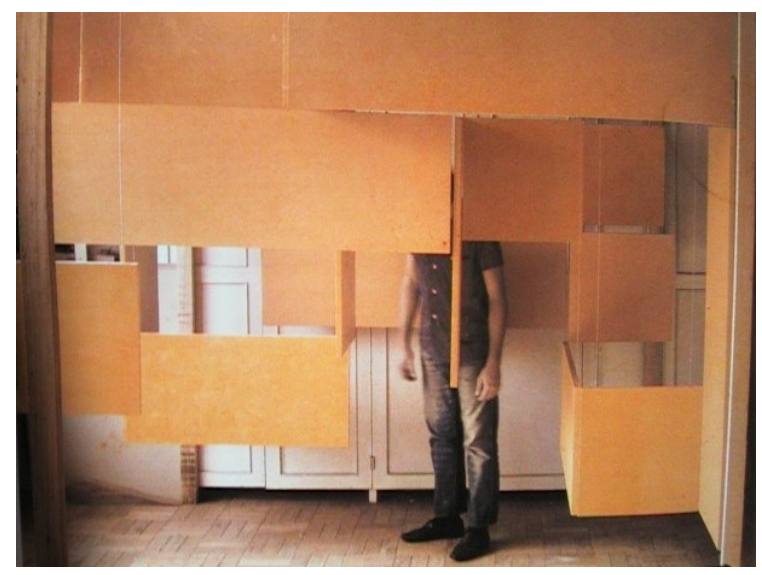

Núcleo 6, 1960-63

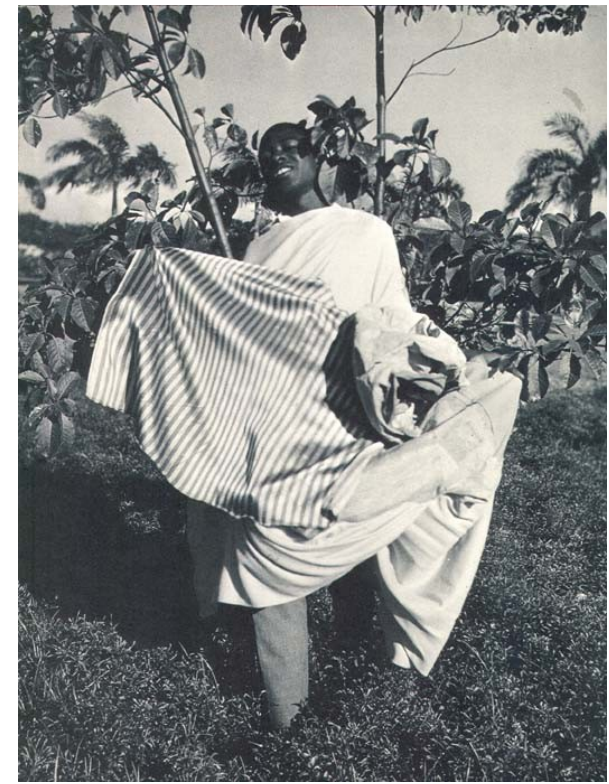

Jerônimo com Capa 5, 1965

(essa foto foi capa do catálogo da Whitechapel Experience em 1969)

373 GIL, Gilberto. De onde vem o Baião, 1977: "Debaixo do barro do chão da pista onde se dança/ Suspira uma sustança sustentada por um sopro divino/ Que sobe pelos pés da gente e de repente se lança Pela sanfona afora até o coração do menino// Debaixo do barro do chão da pista onde se dança/ É como se Deus irradiasse uma forte energia/ Que sobe pelo chão/ E se transforma em ondas de baião, xaxado e xote/ Que balança a trança do cabelo da menina, e quanta alegria!.” Agradeço a Flávia Tiné por me indicar essa música durante a escrita deste capítulo. 
Corpo que incorporou o ambiente: eis a "descoberta do corpo" que será citada em vários textos principalmente na década de 1970 e que sinaliza que, para Oiticica, houve uma mudança no estatuto do corpo a partir do contato com a Mangueira, especificamente com a dança, ainda que bilaterais e penetráveis já mobilizassem, de forma incipiente, o corpo.

$\mathrm{O}$ mito ${ }^{374}$ nessa época confunde-se nos escritos de Oiticica com a reflexão sobre a ontologia da arte. No mesmo texto em que anuncia o parangolé como "vontade de um novo mito" Oiticica diz que "resta talvez uma procura da definição de uma 'ontologia da obra', uma análise profunda da gênese da obra enquanto tal." ${ }^{375}$ De fato, mito e ontologia caminham juntos segundo Mircea Eliade:

O mito proclama a aparição de uma nova 'situação' cósmica ou de um acontecimento primordial. Portanto é sempre a narração de uma 'criação.' Conta-se como qualquer coisa foi efetuada, começou a ser. É por isso que o mito é solidário da ontologia: só fala das realidades, do que aconteceu realmente, do que se manifestou plenamente. ${ }^{376}$

Veremos que na década seguinte, a questão da ontologia da obra de arte cede lugar à aparição do inventor e artista trágico. Oiticica abole o mito -- que conta a origem do que já existe - pois passa a se interessar pelo que há de vir: desmitifica. Assim, dirá que tudo o que fez até então foi prelúdio ${ }^{377}$ e anunciará um processo de emergência do artista trágico "que até então nunca existiu." ${ }^{" 378}$ Em nova síntese, Oiticica desloca o corpo para além do corpo que dança aspirando ao mito, e anuncia o "Parangolé-síntese:"

1964, PARANGOLÉ-primeiro

$\downarrow$
$=$ a obra requer aí a participação corporal direta;
além de revestir o corpo, pede que este se movimente,

${ }^{374}$ Para um trabalho que analisa a obra de Oiticica como construção de estruturas míticas, cf. VAZ, Suzana. "HO|ME Hélio Oiticica e Mircea Eliade: mitologia radical de padrão iniciático" in Fios Soltos: A Arte de Hélio Oiticica, op. cit.

${ }^{375}$ OITICICA, Hélio. "Bases Fundamentais para uma definição do Parangolé", op.cit.

${ }^{376}$ ELIADE, Mircea. O Sagrado e o Profano: a essência das religiões. São Paulo: Martins Fontes, 2001. p. 85.

${ }^{377}$ OITICICA, Hélio. "Texto feito a pedido de Daisy Peccinini como contribuição para uma publicação sobre o objeto na arte brasileira nos ano 60". PHO 101.77

${ }^{378}$ OITICICA, Hélio. "O q Faço é MÚSICA", 1979, op. cit. 
que dance em última análise. $=$

naquela época a

\section{DANÇA}

era para mim aspiração ao mito, mas, mais importante, já era

in-corporação

hoje ela é nada mais q

climax corporal

não-display

auto-climax

NÃO-VERBAL

$(\ldots)=$ inventions are extensions of man's energy $=$

I Seem to Be

A verb-

Fuller with

Angel and Fiore

não me interessa na dança o seu estado naturalista de

'manifestação humana' nem reduções a ego-trip (fragmentação

neuro-psíquica) mas liberação das capacidades de

play

é

INVENÇÃO-PLAY ${ }^{379}$

A cada "síntese", Oiticica reinaugura a descoberta do corpo. Nos bilaterais e núcleos, o corpo era um aparelho sensorial. Na Mangueira, a expressão artística "nascia da terra" e o corpo, pela dança, in-corporava essa força arcaica. Na década de 1970, o corpo que dança se desprende da terra, desmitificado. A invenção (força artística) passa a ser extensão do próprio corpo e a dança libera-a em "climax corporal".

À medida em que o corpo incorpora novos papéis, como que revestido de novas fantasias, altera-se seu comportamento ético-social. $\mathrm{Na}$ Mangueira, o artista articula essa mudança descrevendo um gesto: "pisar a terra de novo" 380 , estar ciente do

379 OITICICA, Hélio. "Parangolé-síntese”, 1972, op.cit.

${ }^{380}$ OITICICA, Hélio. "Perguntas e respostas a Mario Barata”, 15/05/1967, em Grande Labirinto, op.cit., p.99 . Aspiro ao 
movimento não em sua utilidade de ato mas em sua intransitividade de gesto, e com isso passar por um descondicionamento social.

O gesto nada mais é do que o ato considerado na totalidade do seu desenrolar, percebido enquanto tal, observado, captado. $\mathrm{O}$ ato é o que resta de um gesto cujos momentos foram esquecidos e do qual só se conhecem os resultados. O gesto se revela mesmo que sua intenção seja prática, interessada. $\mathrm{O}$ ato se resume em seus efeitos, ainda que quisesse se mostrar espetacular ou gratuito. Um se impõe com o caráter perceptível de sua construção; o outro passa como uma prosa que transmitiu o que tinha a dizer. O gesto é a poesia do ato. (...) [C]onsideremos como sendo gestos apenas os movimentos do corpo que são intransitivos, que são programas inteiros (...) A poesia, seja ela verbal ou gestual, reanima os signos extintos, para que toda a prosa se torne assim mais viva. ${ }^{381}$

As pedras e quebradas do morro revelarão então para o artista a força artística que "pequenos atos" como pisar o chão e outros do viver diário carregam:

Indispensabilíssima é essa descoberta da "comunhão", essa descoberta que nada mais é do que um "religamento" do indivíduo às origens míticas primordiais, de onde veio e há longo tempo se afastou. Mas essa volta não é um regresso e sim uma descoberta de si mesmo no que há de mais essencial: não sou mais do que meu semelhante por questões sociais, intelectuais, etc.; sou igual porque tenho em mim, a descoberto, potencialidades que a cada um são dadas de modo diverso segundo sua estrutura individual - e todas são válidas porque são manifestações do individual e por isso devem ser respeitadas como tal (...) toda tentativa individual de expressão deve ser respeitada como uma "arte" (...) Isso coincide com a famosa frase de Klee (que ninguém entende!) de que o processo criador nasce da repetição e da multiplicação de "pequenos atos" (...) O processo criador tende a se identificar com a própria vida, a nascer em consonância com o viver diário. ${ }^{382}$

Pequenos atos cotidianos podem estar relacionados ao mito se não forem atos alienados. Vimos acima que segundo Mircea Eliade, o mito trata daquilo que é real. O real, no registro do mito, é aquilo que participa do "ser", aquilo que não é profano. O trabalho agrícola, por exemplo, é real e significativo em uma sociedade que o vê como sagrado, como algo revelado pelos heróis ou deuses. Uma sociedade dessacralizada não

\footnotetext{
${ }^{381}$ GALARD, Jean. A Beleza do Gesto. São Paulo: EDUSP, 1997, p. 27, 32 e 37.

382 OITICICA, Hélio. “À Busca do Suprasensorial”, 10/10/1967, op.cit. Sobre esse texto, cf. também tópico 2.4 Branco: Cor-tempo.
} 
vê o trabalho agrícola como parte do "ser", mas apenas como ato profano de proveito econômico. Para Oiticica, o trabalho do artista é o mais real de todos, já que é marginal à produção alienada. $\mathrm{O}$ artista, diz Oiticica, não só deve denunciar essa sociedade alienada mas também "desmitificar os mitos da classe dominante" com uma posição permanentemente crítica e marginal. ${ }^{383} \mathrm{Com}$ o comportamento não alienado, como por exemplo no Crelazer, restitui-se ao ato cotidiano o estatuto de gesto, significativo, em consonância com a "vontade de um novo mito." Crelazer pode ser entendido como um lazer que participa do "ser", ao contrário do divertimento alienado. Seria então o lazer real. Mas qual o momento original, de revelação desse real que um "novo mito" recontaria? Quem é o herói fundador do lazer real? Com Crelazer, o mito começa a ceder lugar para a alteridade, para o novo. O gesto ou conduta - que em Oiticica aparece como "comportamento" -- pode ser uma "possibilidade de introduzir a alteridade em si - e conceber um comportamento que seria doravante capaz de engendrar um sujeito plural em vez de exprimir uma pessoa constituída (...) Toda ocasião se presta a essa defasagem íntima (...) Assim se extingue a espera ansiosa dos momentos de exceção." ${ }^{934}$

Entrar em um ninho é descondicionar-me do que sempre sou, gesto similar a vestir uma fantasia no carnaval mas que abole a espera pela festa, integra-se ao cotidiano pois, como o contra-bólide do "Acontecimento Poético-Urbano Kleemania", "pode ser repetido quando houver ocasião ou necessidade para tal. ${ }^{385} \mathrm{Na}$ vivência da pluralidade advinda do descondicionamento, como na fantasia, eu sou eu e não sou eu: "não ser desertado, nem possuído, mas exatamente o que se chama ser 'habitado'.

Lembremos que o labirinto Éden, montado na Whitechapel Gallery em torno do conceito de Crelazer, terminava com o "núcleo de lazer área aberta ao mito", um cercado

\footnotetext{
383 OITICICA, Hélio. Carta para Lygia Clark de 8/11/1968 em CLARK, Lygia e OITICICA, Hélio. Lygia Clark - Hélio Oiticica: Cartas, 1964-74., op. cit., p. 74-75.

${ }^{384}$ GALARD, Jean, op. cit. p. 120 e 122.

${ }^{385}$ Frase de Oiticica a respeito do contra-bólide "Devolver a Terra à Terra" que integrou uma homenagem a Paul Klee. (cf. OITICICA, Hélio. "Devolver a Terra à Terra", op. cit.) Segundo Oiticica, lembremos, Paul Klee considerava o processo criador como consequência da repetição e da multiplicação de pequenos atos. (cf. OITICICA, Hélio. “À Busca do Suprasensorial”, op. cit.)

${ }^{386}$ GALARD, Jean, op. cit p. 120
} 
circular vazio, "campo para construção de um espaço significativo 'seu' (...) estar-se no estado de 'fundar' o que não existe ainda, de se auto-fundar." ${ }^{\text {"387 }}$
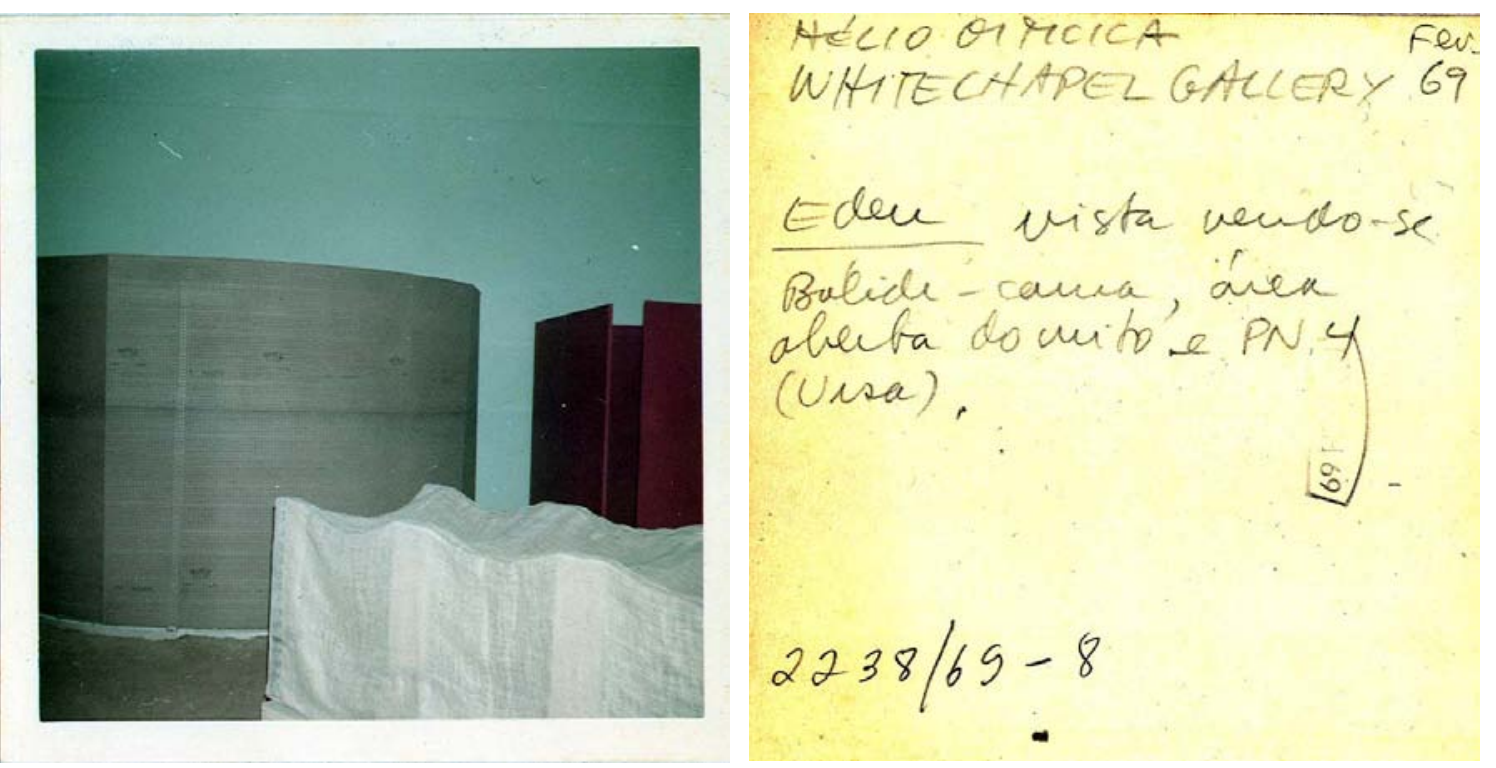

Frente e verso de fotografia do Éden na Whitechapel Gallery, Londres, 1969. Vê-se Bólide cama (branco), Área aberta ao mito (cinza) e PN4 Ursa (vermelho). AHO 2238.69-p3 e p4.
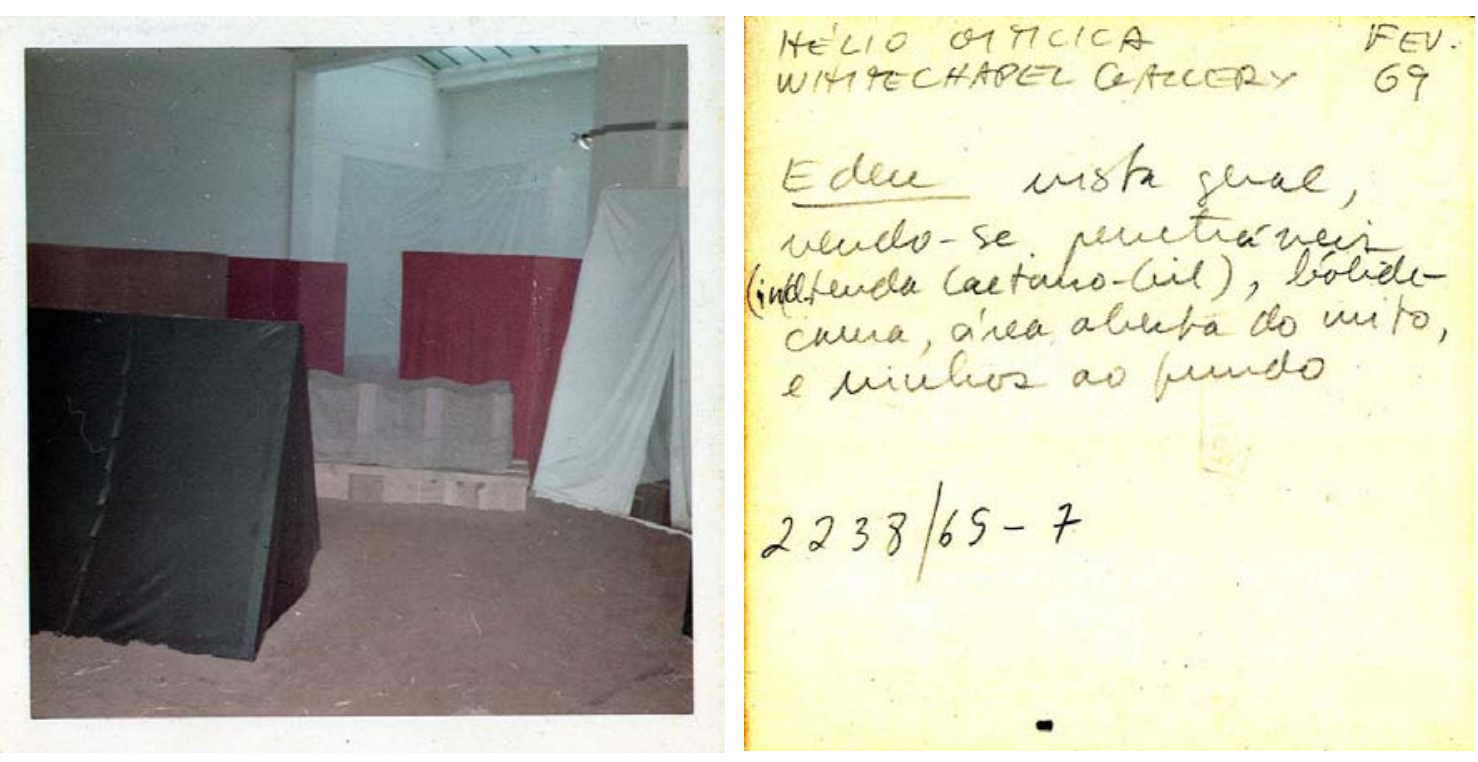

Vista geral do Éden, com ninhos ao fundo. AHO 2238.69-p7 e p8

$\overline{387}$ OITICICA, Hélio. “As Possibilidades do Crelazer”, 1969, op. cit. 
"Fundar o que não existe" de forma tão significativa que implique um autofundar-se: vemos aqui que a "área aberta ao mito" foi semente do processo de desmitificação - o mito relata a fundação do que já existe, efetuada por deuses ou heróis. Com Crelazer, Oiticica esgarça o mito ao tentar esticá-lo de forma a acolher as teorias de Herbert Marcuse sobre comportamento alienado. ${ }^{388}$ Simultaneamente a passeatas contra a repressão política no Brasil e aos movimentos contra-culturais nos Estados Unidos, Crelazer institui o participador como o próprio herói que funda o que não existia no exato instante em que transforma ato em gesto. O espetáculo é mínimo pois esse gesto de autofundação acontece sem público, dentro de tendas, ninhos ou no cercado da "área aberta ao mito."

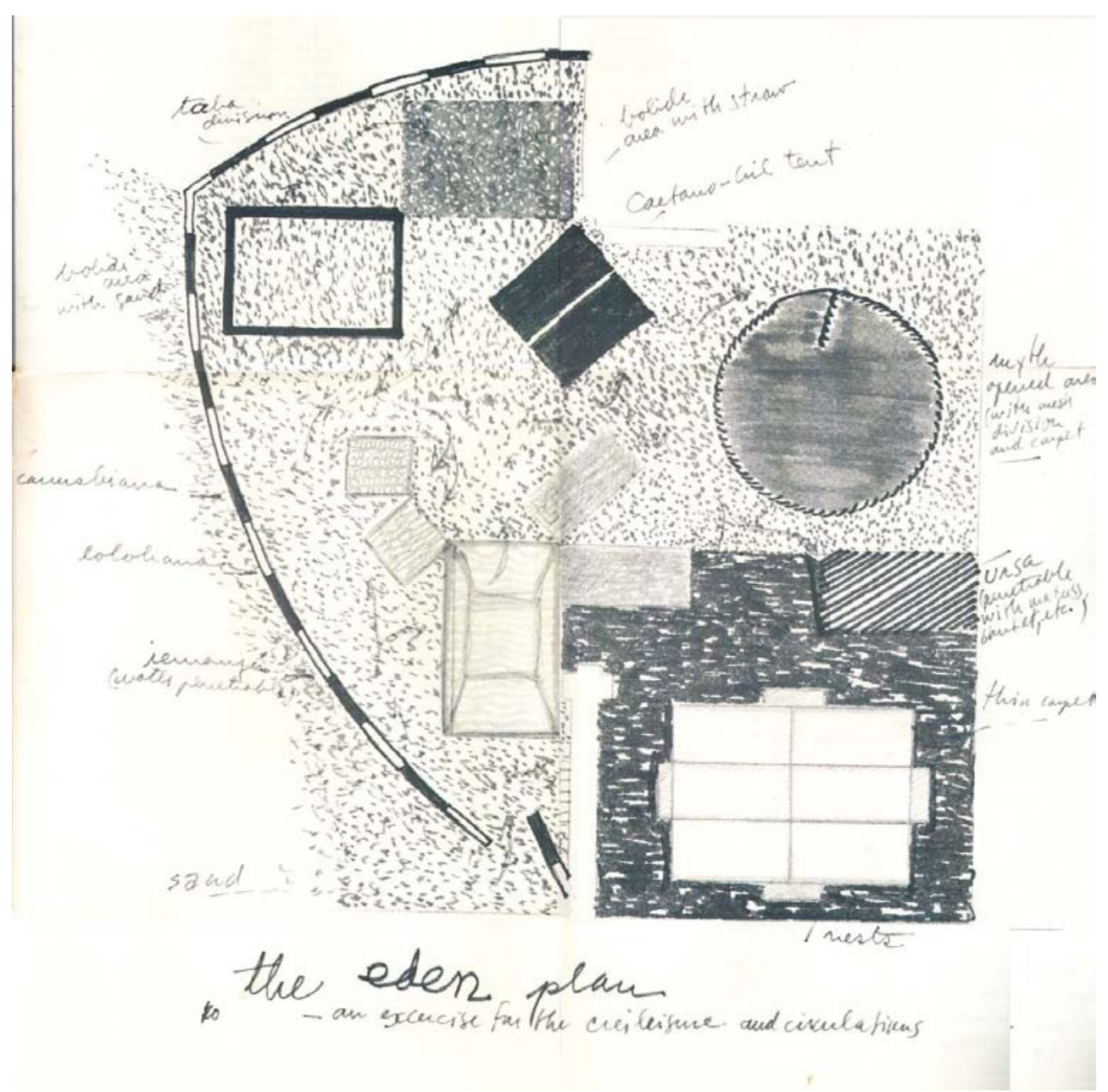

Planta do Éden, Whitechapel Gallery, 1969

${ }^{388}$ cf. Tópico 3.2 "O texto não publicado: 'Os sentidos apontando para uma nova transformação"” 
No processo de estabelecimento do novo herói, Oiticica passará na década de 1960 pela valorização daqueles que assumem uma posição à margem na sociedade: "seja marginal, seja herói." Em carta para Lygia Clark de 1968, Oiticica invoca Marcuse para articular mito e marginalidade:

Para Marcuse, os artistas, filósofos, etc., são os que (...) "agem marginalmente" pois não possuem "classe" social definida, mas são o que ele chama de "desclassificados", e é nisso que se identificam com o marginal, isto é, com aqueles que exercem atividades marginais ao trabalho produtivo alienante: o trabalho do artista é produtivo, no sentido real da produção-produção, criativo, e não alienante como os que existem em geral numa sociedade capitalista. Quando digo "posição à margem" quero algo semelhante a esse conceito marcuseano: não se trata da gratuidade marginal ou de querer ser marginal à força, mas sim colocar no sentido social bem claro a posição do criador, que não só denuncia uma sociedade alienada de si mesma mas propõe, por uma posição permanentemente crítica, a desmitificação dos mitos da classe dominante $(\ldots)^{389}$

Em contato com a marginalidade da Mangueira, Oiticica buscou vivências sociais coletivas, destruiu o "condicionamento burguês" a que estivera submetido 390 -conseqüentemente destruiu o mito do artista único e genial -- e homenageou o marginal Cara de Cavalo, metáfora para o herói de uma mitologia "não-burguesa." Buscou também um novo mito da expressão artística em manifestações populares e coletivas como o carnaval, o jogo de bilhar, o futebol. Mas não há aqui uma procura de "raízes populares.” O que Oiticica procura nas quebradas do morro é a proveniência da expressão artística, a multiplicidade de forças que a constitui, ${ }^{391}$ a fundação de um campo de forças que revele diversos veios, que interajam com os "mitos da classe dominante" citados na carta para Lygia Clark, transformando-os.

Ainda na década de 1960, a palavra "raiz" ocorre nos textos de Oiticica em deslizes verbais que podem causar mal-entendidos -- ,"a capa não é um objeto mas um

${ }^{389}$ OITICICA, Hélio. Carta para Lygia Clark de 8/11/1968 em CLARK, Lygia e OITICICA, Hélio. Lygia Clark - Hélio Oiticica: Cartas, 1964-74, op. cit., p. 74-75.

${ }^{390}$ OITICICA, Hélio "A dança na minha experiência", op. cit.

${ }^{391}$ cf. FOUCAULT, Michel. "Nietzsche, a Genealogia, a História" (1971) in . Arqueologia das Ciências e história dos sistemas de Pensamento (Ditos e Escritos II). MOTTA, Manuel Barros da (org.) Rio de Janeiro: Forense Universitária, 2000. 
processo de experimentação, buscando as raízes da origem da obra de arte. É por isso que seu método construtivo é popular e primitivo, referindo-se a bandeiras, tendas, capas, etc. "392 -- mas Oiticica logo ajusta seu discurso, usando "raiz-estrutura" e "raiz-aberta"393

formulação da idéia de Parangolé em 1964: raiz raiz brasileira ou fundação da raiz Brasil em oposição à folclorização desse material raiz (...) Parangolé se ergue desde 64 contra essa folclorização opressiva e usa o mesmo material que seria outrora folc-Brasil como estrutura nãoopressiva, como revelação de uma realidade minha-raiz - Jerônimo, na foto [da capa do catálogo da Whitechapel Experience] vestindo a capa (Aterro, 1967), revela toda uma síntese: é inexplicável o que se passa aí: o modo com que se veste na planta e veste a capa é dado pela posição gestual-facial que expressa mais do que um simples posar : é Brasil-raiz, intransferível, mas não se limita a uma "imagem Brasil": é raiz estrutura e é não opressiva porque revela uma potencialidade viva de uma cultura em formação: digo cultura em formação como possibilidade aberta de uma cultura (...) Parangolé é a descoberta da raiz-aberta pela primeira vez (...)

Depois de ler Nietzsche nos ninhos dos apartamentos de Nova Iorque, Oiticica abole totalmente a "raiz". Nem raiz-aberta, nem raiz-estrutura, mas pluralidade de veios: "nunca as malfadadas tão faladas 'raízes' que são empecilho à invenção criativa"394 e declara que as raízes haviam sido há muito tempo arrancadas e queimadas. ${ }^{395}$ Seu construtivismo, com efeito, sempre admitiu a destruição:

\begin{abstract}
A anti-arte é pois uma nova etapa (é o que Mario Pedrosa sabiamente formulou como arte pósmoderna); é o otimismo, é a criação de uma nova vitalidade na experiência humana criativa; o seu principal objetivo é o de dar ao público a chance de deixar de ser público espectador, de fora, para participante na experiência criadora. É o começo de uma expressão coletiva (...) a vitalidade, individual e coletiva, será o soerguimento de algo sólido e real, apesar do subdesenvolvimento e caos - desse caos vietnamesco é que nascerá o futuro, não do conformismo e do otarismo. Só derrubando furiosamente poderemos erguer algo válido e palpável: a nossa realidade. ${ }^{396}$
\end{abstract}

\footnotetext{
${ }^{392}$ OITICICA, Hélio. Catálogo da exposição Whitechapel Experience, Londres, 1969.

${ }^{393}$ OITICICA, Hélio, "Barracão" AHO 452.69

${ }^{394}$ OITICICA, Hélio "O q Faço é MÚSICA", op. cit. Para a transcrição completa do trecho sobre raízes e linearidade, cf. tópico 2.3 "Singultâneo: o retorno do que avança".

${ }^{395}$ OITICICA, Hélio. "Hélio Oiticica está de volta", entrevista a Cleusa Maria. Jornal do Brasil, 08/03/1978. AHO 0899.78

${ }^{396}$ OITICICA, Hélio. "Posição Ética”, 1966. AHO 253.66.
} 
como aceitar ou admitir uma vontade construtiva implícita nas atitudes criativas e ao mesmo tempo admitir outra, que seria transformadora ou até mesmo destrutiva ou maldita (como o querem alguns)(...) A vontade construtiva, por possuir em seu cerne essa ambivalência, já é por si mesma transformadora, demolidora, também um fenômeno ético-social característico na sua maneira específica de se manifestar. ${ }^{397}$

"Parangolé", diz Oiticica no final da década de 1970, é o nome dado à "estrutura elástico-adaptativa que chega sempre como instauração do novo,"398 é um "programa além da arte"399 que conduz "à dança, à fantasia-vestir, às ruas, ao sonho do lazer ambiental feito e programado no dia-a-dia, e à síntese-construção. ${ }^{״ 400}$ Essa síntese toma forma no final da década nos grandes labirintos públicos das séries invenção da cor e invenção da luz que são

a culminância do dia do veio mais fino e grandioso - essencial e grandioso da arte moderna $q$ $\mathrm{vem}^{401}$ via MALIÉVITCH-CONTRUTIVISMO/ MONDRIAN- NEOPLASTICISMO/ BAUHAUS-CONCRETO: é o alimento do novo: é o grito de aspiração à vida.

Parangolé: atingimento programático da fundação de espaço: nisto se resume a SÍNTESE TOTAL a q aspira a formulação do PARANGOLÉ e a programática da descoberta do corpo ${ }^{402}$

Mesmo depois do "processo de desmitificação" o parangolé continuará associado à expressão coletiva, que culmina na proposição do Mundo-Abrigo -novamente fundação de espaço -- e do homem que o habita, o inventor, que busca o novo vivendo segundo uma ética e uma estética do "instante e do gesto,"403 que "faz o novo no dia" ${ }^{\prime 404}$, no cotidiano.

${ }^{397}$ OITICICA, Hélio, sem título, 18/03/67, AHO 109.67

${ }^{398}$ OITICICA, Hélio. "Anotações Conta-Gota (para livro de Antônio Manuel sobre o corpo e implicações na arte, etc.", 28/08/1978. AHO 0091.78-p14 a p20 e p23 a p24 (manuscrito) e 0090.78 (datilografado por terceiros, com erros em relação ao manuscrito).

${ }^{399}$ ibid.

${ }^{400}$ ibid.

${ }^{401} \mathrm{Na}$ versão datilografada lê-se "quem". Na versão manuscrita, Oiticica escreve claramente "q vem", conforme usamos aqui.

${ }^{402}$ OITICICA, Hélio. "Anotações Conta-Gota (para livro de Antônio Manuel sobre o corpo e implicações na arte, etc.", 28/08/1978, op.cit.

${ }^{403}$ FAVARETTO, Celso."60/70 : Viver a Arte, inventar a Vida" Seminário "Vida Coletiva, XXVII Bienal de S. Paulo, 2006 e GALARD, Jean. A Beleza do Gesto:uma estética das condutas. São Paulo: EDUSP, 1997.

${ }^{404}$ OITICICA, Hélio. “Anotações Conta-Gota”, op. cit. 


\subsection{Desmitificação}

Durante a exposição na Whitechapel Gallery, a revista britânica Studio International publicou uma entrevista de Hélio Oiticica concedida a Guy Brett na qual o artista declara estar em busca de "um tipo de participação diferente daquela dos rituais," já que nestas a participação é, segundo Oiticica, estereotipada. ${ }^{405} \mathrm{Na}$ mesma época, Oiticica publicou um texto na também londrina Art and Artists no qual afirma que o Éden era "a primeira manifestação sintética do pensamento do Crelazer, embora ritos e mitos através das épocas tenham sido sua manifestação espontânea." ${ }^{\text {"06 }}$ No paradoxo entre o espontâneo e o estereótipo, há a constatação de Oiticica de que o rito tende a diluir-se e estereotipar-se: é preciso então reinventar o mito e sua celebração ritual. O processo de mitificação será sempre importante para Oiticica "mas ele tem que vir acompanhado do processo de desmitificação." ${ }^{407}$

\section{Subterrâneo}

Ainda que afastado do mito da Mangueira como morada inicial da expressão artística, Oiticica continua a atrelar a invenção ao chão, a um "subterrâneo" que emana uma força transgressora: sub-terra para sub-verter a palavra underground, sub-mundo, sub-sub, sub-way diz Oiticica em finais de $1969:{ }^{408}$ ir ao fundo para superar a diluição superficial. ${ }^{409}$

Antes de encontrar abrigo subterrâneo, Oiticica experimentou uma sensação de "falta de lugar no mundo" articulada em Londocumento:

depois da Whitechapel (primeira e última experiência)

depois de Paris com Ceres Franco fazendo Rhobo de Jean Clay

depois de Los Angeles com Lygia $\operatorname{Clark}^{410}$ (...)

depois de Nova Iorque com gerchmann, cujo trabalho cresce dia-a-dia

\footnotetext{
${ }^{405}$ OITICICA, Hélio. "Hélio Oiticica retrospective at the Whitechapel Gallery, until April 6: Oiticica talks to Guy Brett”. Studio International, Março/1969, v. 177 no. 909, p. 134.

${ }^{406}$ OITICICA, Hélio. "On the discovery of Creleisure". Art and Artists, abril/1969, op.cit.

${ }^{407}$ OITICICA, Hélio. Áudio da entrevista a Ivan Cardoso, op. cit.

408 OITICICA, Hélio. "Subterrânia 2" em . Aspiro ao Grande Labirinto. op.cit. p. 127 e AHO 382.69-a-p1. Texto sem data, provavelmente do final de 1969.

409 cf. KOSSOVITCH, Leon. op. cit., p. 170

${ }^{410}$ Oiticica refere-se aqui ao Simpósio de Arte Tátil de Los Angeles. cf. capítulo 3. Conceitualismo e Vivência
} 
estou "again" em Londres

E NÃO TENHO LUGAR NO MUNDO

onde está o Brasil - que represento nele ou onde está a paixão pelo Rio (...)

o mundo me parece pequeno e feio (...)

procuro o crelazer: faço os planos, começo e recomeço - parece que começo e recomeço não terminam e são o sentido do que não existe e se procura erguer $(. . .)^{411}$

O tom de Londocumento não é sombrio; é de contrariedade afirmativa: "eu sou o underground da América Latina!(...) eu sou o trópico sol, serei a explosão minha e sua (...) sou o desafio de mim mesmo; sempre adorei o que me é oposto e desafio." $\mathrm{O}$ apreço pelo que é oposto explicitado neste texto de 1969 anuncia a importância da obra de Nietzsche no pensamento de Oiticica durante a década que começaria. Ainda sob o som afirmativo de Londocumento, é interessante comparar o movimento de Oiticica em direção ao subterrâneo com a primeira frase do prólogo de Aurora: "Neste livro se acha um 'ser subterrâneo' a trabalhar, um ser que perfura, que escava, que solapa. Ele é visto pressupondo que se tenha vista para esse trabalho na profundeza - lentamente avançando, cauteloso, suavemente implacável, sem muito revelar da aflição causada pela demorada privação de luz e ar." ${ }^{\text {‘12 }}$

Talvez o pensamento afirmativo de Nietzsche tenha aberto, para Oiticica, um lugar na terra quando o artista saiu do abrigo do mito, territorializando afirmativamente a "falta de lugar no mundo." "Sub-enterrar ou nascer do sub para a SUBTERRÂNIA?"413 Escrito todo em caixa-alta e com um "i”, o termo sugere a nomeação de um lugar. O novo abrigo da arte depois da Whitechapel Experience é a SUBTERRÂNIA: "toda atividade de criação (se bem que o problema não se resuma a isso) existe como que enterrada ou se manifesta sob a indiferença da chamada 'cultura brasileira'." SUBTERRÂNIA seria assim a glorificação do sub para vencer a "super-repressão e a super-paranóia brasileiras". ${ }^{414}$

${ }_{411}$ OITICICA, Hélio. "Londocumento", 27/08/1969. AHO 304.69

${ }^{412}$ NIETZSCHE, Friedrich. Aurora: reflexões sobre os preconceitos morais. Paulo César de Souza (trad.). São Paulo: Companhia das Letras, 2004.

${ }^{413}$ OITICICA, Hélio. Sem título, título atribuído "Meu trabalho é subterrâneo", 10/03/1970. AHO 307.70

${ }^{414}$ OITICICA, Hélio. "Subterrânia", 21/09/1969. AHO 382.69 
A construção da SUBTERRÂNIA "consequentiza-se" na escrita de "Brasil Diarréia", a constatação do estado de diluição, da impossibilidade de convivência com o Brasil da conivência: "propor uma mudança é mudar mesmo, e não conviver com o banho de piscina paterno-burguês ou com o mingau da 'crítica d'arte' brasileira." ${ }^{415} \mathrm{Com}$ o "subterrâneo", assim como fez com Tropicália, Oiticica tenta solapar a face Brasil folclorizada e "construir a face Brasil sem disfarces." ${ }^{416}$ Com Tropicália, Oiticica tentara reverter um "arianismo inadmissível", e constituir uma "imagem brasileira total." A "imagem", no entanto, fora assimilada sem o elemento vivencial direto: "imagens são tão frequentemente usadas para opressão. Podem também ser pegas e repetidas sem reflexão." ${ }^{17}$ A "marginalidade" caíra no gosto dos "burgueses, subintelectuais, cretinos de toda espécie (...) os que faziam stars and stripes já estão fazendo suas araras, suas bananeiras etc., ou estão interessados em favelas, escolas de samba, marginais anti-heróis (Cara de Cavalo virou moda, etc.)" ${ }^{418}$ Oiticica então se afasta da diluição, transformandose na própria força subterrânea que, não sendo imagem, não pode ser exposta, e declara em 1969: "à minha atividade atual, no seu todo, quero chamar de 'subterrânea': não será exposta, mas feita; seu lugar no tempo é aberto." ${ }^{\$ 19}$

O texto Brasil Diarréia reafirma essa condição subterrânea como posição "para além da marginalidade":

a condição brasileira, mais do que simplesmente marginal dentro do mundo, é subterrânea, isto é, tende e deve erguer-se como algo específico, ainda em formação; a cultura (detesto o termo) realmente efetiva, revolucionária, construtiva, seria essa que se ergueria como uma SUBTERRÂNIA $^{420}$ (escrevi um texto com esse nome, em setembro 69, em Londres): assume toda a condição de subdesenvolvimento (sub-sub).

\footnotetext{
${ }^{415}$ OITICICA, Hélio. "Brasil Diarréia”, op. cit.

${ }^{416}$ OITICICA, Hélio. Sem título, título atribuído "Meu trabalho é subterrâneo”, 10/03/1970 AHO 307.70

${ }^{417}$ OITICICA, Hélio. "Hélio Oiticica retrospective at the Whitechapel Gallery, until April 6: Oiticica talks to Guy Brett”. Studio International, Março/1969, v. 177 no. 909, p. 134. (tradução da autora)

${ }^{418}$ OITICICA, Hélio. Sem título, 4/03/1968, em ___. Aspiro ao Grande Labirinto, p. 108.

${ }^{419}$ OITICICA, Hélio "Experiência londrina: Subterrânea”, 27/01/1970. AHO 290.70

${ }^{420} \mathrm{O}$ manuscrito de Hélio Oiticica, de fevereiro de 1970, grafa SUBTERRÂNIA. cf. AHO 328.70. A reprodução desse texto no catálogo da exposição retrospectiva de 1992-97 alterou a grafia para SUBTERRANEA.
} 

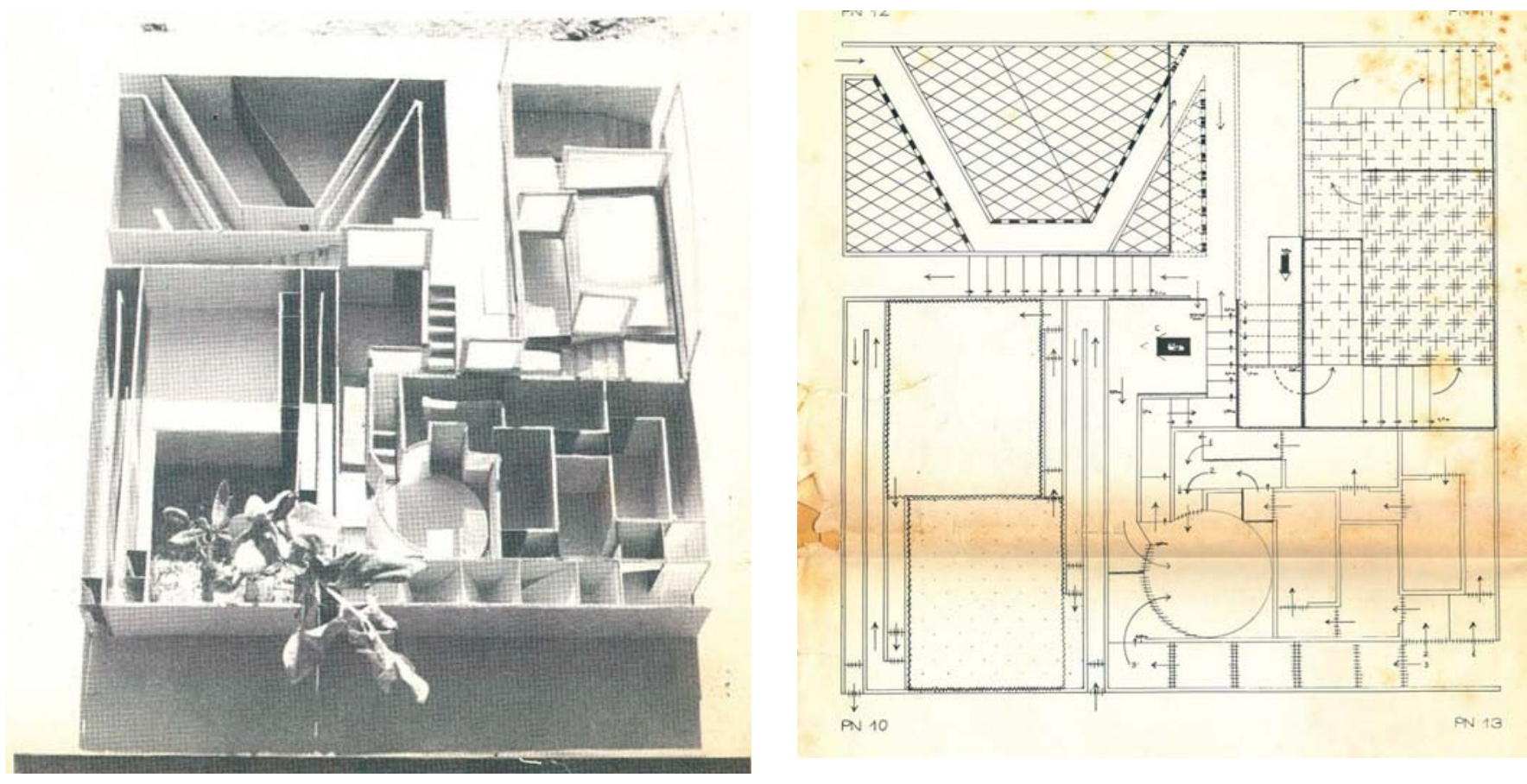

Maquete e planta do primeiro andar de "projeto 1" de subterranean Tropicalia Projects com 4 penetráveis (PN10 a PN13). AHO 1833.72

A Tropicália será retomada no subterrâneo, protegida da diluição que transformou um questionamento em solidificação folclórica da imagem Brasil. Surgem assim em 1971, quando Oiticica já está em Nova Iorque com a bolsa Guggenheim, os subterranean Tropicalia Projects, labirintos de penetráveis cujos registros e fotografias de maquetes remetem mais ao Projeto Cães de Caça de 1961 do que à Tropicália de 1967 ou ao Éden de 1969. Nestes, a separação entre exterior e interior era bem definida pois os penetráveis ficavam espalhados, isolados uns dos outros em uma grande área; o "projeto 1" de subterranean Tropicalia Projects, ao contrário, conglomera seus 4 penetráveis (PN11 a PN14), separando-os apenas por uma pequena área central, como um pátio interno, e corredores de circulação. Os blocos de construção aqui não estão espalhados como em Tropicália e Éden, mas encaixados uns nos outros, formando um bloco maior, compacto. Há escadas, pisos superpostos e terraços voltados para as áreas interiores. A abertura ocorre no piso superior, que não tem teto. O penetrável PN10 
recria uma área de vegetação densa, para sugerir a idéia de "exterior fechado." No $P N 11$, o participador engatinha para entrar em redes bem esticadas ${ }^{421}$, repousar e sair. PN12 tem 3 áreas para performance circundadas por janelas, e corredores de onde se pode assistí-las. PN13 também é uma área para "práticas do self espontâneo, nãoritualísticas, como uma verdadeira posição de anti-arte permanente." 422

Como sugerido pelos corredores do "projeto 1" de subterranean Tropicalia Projects, planejado para o Central Park, o ser subterrâneo não está sub-enterrado mas movendo-se, em comportamento espontâneo, não-ritualístico.

\section{Meditar-andar}

Além de inverter o lamento de "falta de lugar no mundo" ao transformá-lo em afirmação com o subterrâneo, Oiticica acha um outro tipo benéfico e revigorante de falta de lugar no "dreamtime," ${ }^{423}$ prática de aborígenes australianos que, como o artista relata em 1969, consiste em sair da taba e "vagar pelo deserto sem saber aonde estão indo." ${ }^{424} \mathrm{O}$ "dreamtime" aparecerá de novo como vontade de falta de lugar no mundo nas proposições do delirium ambulatorium, por volta de 1973, "re-clarificado e re-lembrado" por Guy Brett. Será então caracterizado como estratégia para escapar da fixidez da cultura, das obrigações sociais (que incluem seus ritos e mitos), e abrir-se ao novo, procurando-o no mundo exterior:

Guy descobriu/revelou-me muitas coisas mas acima de tudo falou-me do DREAMTIME como parte do padrão social das TRIBOS ABORÍGENES: e reclarificou/relembrou-me isso hoje: no livro de Eliade (qual?) descobriu que durante períodos intermitentes o

\footnotetext{
${ }^{421} \mathrm{O}$ manuscrito do texto original, escrito em inglês, descreve "stretched (strong circus net)" (Arquivo HO 266.71). Acreditamos que Oiticica tenha trocado uma letra na palavra "stretcher", que é uma cama improvisada, como uma maca, feita com um tecido forte bem esticado. Pelo texto, conclui-se que seriam algo como redes circulares bem esticadas, montadas em duas alturas diferentes, com um metro de distância na direção vertical. Um outro manuscrito, escrito em português descreve essas estruturas como "2 redes de circo esticadas; gatinha-se para dentro das redes; fica-se; sai-se depois". OITICICA, Hélio. "Subterranean Tropicalia Projects". AHO 269.71

${ }^{422}$ OITICICA, Hélio. "Projects", setembro/1971. Arquivo HO 266.71

${ }^{423}$ Dreamtime é literalmente tempo do sonho ou tempo para o devaneio.

${ }^{424}$ OITICICA, Hélio. "Hélio Oiticica retrospective at the Whitechapel Gallery, until April 6: Oiticica talks to Guy Brett”. Studio International, Março/1969, v. 177 no. 909, p. 134.
} 
indivíduo pertencente a uma tribo (TABA/NUCLEO) deixa a comunidade para deambular sem objetivo na floresta além da TABA: a dispensa de obrigações comunitárias conduz neste caso a uma liberação do pensamento - uma transformação que ocorre dentro do seu comportamento social: papel-social-com-individualidadeconsolidada: suprema forma de lazer não repressivo: a descoberta de Guy direciona-se brilhantemente para o foco principal que gerou muitos dos meus projetos tais como o do Éden, etc.: BARRACÃO: e penetrar nas consequências implicadas numa concepção tal como a de DREAMTIME pode ser (e é) a mais reveladora e efectiva das muitas linhas de pensamento que conduziram a proposições tais como as relacionadas com PARTICIPAÇÃO/COMPORTAMENTO/INVENÇÃO/ LAZER (e CRELAZER)/ ETC. como campos experimentais recentes: Guy de facto revelou-me um vínculo de p a i x ã o dentro da concepção de DREAMTIME.

Quem quer que tenha tido o privilégio de DREAMTIMING só pode ser alguém de sorte e bom gosto - um full timer da experimentação e o único a instalar um padrão comportamental definido de experimentação total dentro dos padrões sociais estabelecidos. ${ }^{425}$

O "dreamtime", tempo do sonho, é desde o texto de 1969 relacionado a uma prática regeneradora, de recuperação de poderes. No Éden, o "dreamtime" advinha do gesto de deitar e descansar, como no sono regenerador. ${ }^{426}$ Com o delirium ambulatorium, a regeneração vem da perambulação: "meu approach ao CAJU se deu pelas vias do delirium ambulatorium recuperador-regenerante" ${ }^{\$ 27}$. A proposta agora é andar, sair para o mundo, para recuperar poderes de invenção, numa prática individual de transformação. No caso dos aborígenes que Oiticica citava, essa prática de transformação individual tem também um papel social, é respaldada pelos códigos da comunidade.

No texto de março de 1969 que cita o "dreamtime", ao falar da liberação da imaginação promovida pelo Crelazer, Oiticica evita usar o termo "meditação": "não quero chamar isso de 'meditar' porque formas orientais de meditação foram transformadas em diversão ou passa-tempo, socialmente controladas em clubes, etc, onde ${ }^{425}$ OITICICA, Hélio. ntbk 2/73, p.98-9. Tradução de Suzana Vaz, conforme publicado no artigo VAZ, Suzana "HO|ME Hélio Oiticica e Mircea Eliade: mitologia radical de padrão iniciático", in Fios Soltos: a Arte de Hélio Oiticica, op. Cit.

${ }^{426}$ OITICICA, Hélio. "Hélio Oiticica retrospective at the Whitechapel Gallery, until April 6: Oiticica talks to Guy Brett”. Studio International, Março/1969, v. 177 no. 909, p. 134. (tradução da autora)

${ }^{427}$ OITICICA, Hélio. "Memorando Caju” 13/04/1979 Programa HO 114/79 
perderam muito de seus poderes." ${ }^{228}$ Dez anos depois, ao citar o "dreamtime" no contexto do delirium ambulatorium em "Memorando Caju", Oiticica repete várias vezes a palavra "meditação":

pelo delirium ambulatorium não só saio da quase-imobilidade do workshop-fermento como dou conseqüência às aspirações ali nascidas - mais -- meditação delas (das conseqüências, dos projetos fermentados, dos pequenos vislumbres do "que quero fazer".(...) o delirium ambulatorium é neste caso a contínua meditação dos momentos transitórios de vida-criação: das aspirações mais carnalmente palpáveis: um desfiar from the bottom of being: pelo delirium ambulatorium é o campo urbano transformado naquilo que L. Clark chamaria de objeto relacional (será?): a cidade do Rio de Janeiro vai-se transfigurando em campo-meditação: em labirinto topográfico da paixão delirium ambulatorial! pelo delirium ambulatorium a meditação é conduzida pelo corpo-pé: a paixão meditar-andar que no workshop fermental gera maqueteslabirintos de topografias criadas. ${ }^{429}$

Mircea Eliade, citado na passagem sobre o "dreamtime" foi um estudioso do yôga mas, como não achamos nenhuma outra evidência sobre o interesse de Oiticica por esse assunto, assumimos que o artista usa o termo "meditação" numa acepção própria, inventada, para definir sua maneira de integrar corpo e mente que, argumentamos, parece ser topológica. A própria entrevista a Guy Brett de 1969, na qual Oiticica cita pela primeira vez o "dreamtime" e explicita sua recusa do termo "meditação", dá uma pista sobre o significado de mapas, maquetes e mente para Oiticica:

Anteriormente, antes de um fazer essas novas cabines, tive a idéia de me "apropriar" de lugares que eu gostava, lugares reais, onde eu me sentia vivo. De fato, o penetrável Tropicália, com sua multitude de imagens tropicais, é uma espécie de condensação de lugares reais. Tropicália é um tipo de mapa. É um mapa do Rio e é um mapa da minha imaginação. É um mapa no qual você entra. Mas agora eu acho mais importante a idéia de as pessoas criarem seus próprios ambientes.

"Mapa do Rio e mapa da minha imaginação" indica mais do que uma sobreposição dois espaços, mas a fusão de ambos em um mesmo modelo - Tropicália e outros labirintos de penetráveis -- que inclinamo-nos a chamar de uma "topologia" que mapeia lugares da cidade e da mente do artista. Meditar-andar, em Oiticica, parece ser

${ }^{428}$ OITICICA, Hélio. "Hélio Oiticica retrospective at the Whitechapel Gallery, until April 6: Oiticica talks to Guy Brett”. Studio International, Março/1969, v. 177 no. 909, p. 134. (tradução da autora)

${ }^{429}$ OITICICA, Hélio. "Memorando Caju”, 1979, op.cit. 
um tipo de pensamento que mobiliza o corpo e a cidade. Meditar-andar seria então um tipo de gesto abrigado por esse lugar total que integra corpo e ambiente: além-ambiente.

Com o meditar-andar, projeta-se no campo urbano uma certa conformação mental. ${ }^{430}$ Pelo meditar-andar, Oiticica absorve o mundo como se este fosse um labirinto de penetráveis, passeia por ele dando "conseqüência" às maquetes feitas no ateliê, gesto similar à proposição de Yoko Ono sobre mapas imaginários (Map Piece, 1962).

Desenhe um mapa imaginário. Coloque uma marca de um alvo aonde você quer ir. Vá andando em uma rua de verdade de acordo com seu mapa. Se não há uma rua onde deveria haver de acordo com seu mapa, faça uma colocando de lado os obstáculos. Quando você atingir o alvo, pergunte o nome da cidade e dê flores para a primeira pessoa que encontrar. O mapa deve ser seguido estritamente, ou o evento tem que ser cancelado. Peça a seus amigos para desenharem mapas. Dê mapas a seus amigos. ${ }^{431}$

Em 1973, Oiticica escreveu um texto sobre o livro Grapefruit de Yoko Ono que cita várias peças de Ono, mas não a Map Piece. ${ }^{432} \mathrm{O}$ texto começa com a transcrição da Pulse Piece: "ouça o pulso de outra pessoa colocando seu ouvido no estômago dela". Oiticica anota que o entendimento que Yoko Ono tem do corpo não é como uma massa colocada em um ambiente, mas como fenômeno de play sensorial, uma "síntese de todas aquelas relações de corpo-ambiente e corpo-corpo." "433 Yoko, segundo Hélio, expande os sentidos do corpo para o mundo-ambiente ("escute o som da terra girando" - Earth Piece, 1963) e embaralha funções do corpo numa estratégia de "mudança de papel" explicitada nas peças que mencionam máscaras ou jogos de esconderijo: “esconda-se até todo mundo ir embora; esconda-se até todos se esquecerem de vocês; esconda-se até todos morrerem." (Hide-and-seek Piece, 1964). Para Oiticica, nessa peça Ono "transforma a própria existência, nunca submetida ao tempo cronológico, em máscara."

Mudar o valor das coisas, Oiticica anota em "Experimentar o experimental" é segundo Ono a tarefa do artista. ${ }^{434}$ A diferença entre Yoko Ono e os artistas conceituais é

\footnotetext{
${ }^{430}$ Aqui é interessante lembrar que Hélio Oiticica, quando criança, decorara a lista de ruas do Rio Janeiro, e sabia dizer onde cada rua começava e terminava. Depoimento de Sônia Oiticica à autora, em 2004.

${ }^{431}$ ONO, Yoko, Map Piece, 1962.

${ }^{432}$ OITICICA, Hélio. "Yoko Ono and Grapefruit", 13/09/1973 AHO 0292.73. Manuscrito preparatório em português em AHO 189.73 p. 47 a p50.

${ }^{433}$ Ibid.

${ }^{434}$ OITICICA, Hélio. "Experimentar o experimental”, 1972, op.cit.
} 
clara para Oiticica, e está justamente na questão da fixidez: Yoko Ono desestabiliza a arte mas não a fixa em outro ponto, mantém o movimento. Os conceituais, segundo Oiticica, transformavam uma ação em um objeto e a partir daí "reconsagravam-no," tratavam-no como o antigo objeto.

As diferenças profundas entre essas proposições em formação de YOKO e as proposições dos "artistas conceituais" é incrível: enquanto YOKO esvazia-retorce-reverte percepção e objeto, linearidade de texto e play-ação, etc., os "conceituais" fazem o oposto: tentam reconsagrar ações-play naturalistas ${ }^{435}$, objeto linear, jogando a "performance do objeto (de arte)" milenar num tipo de gratuidade abstrata: o conceito da ação objetiva como objeto. YOKO que precede, dura e prossegue quer algo mais radical: não quer "criar nova linguagem de arte" mas propõe invenção pura de processo em formação q engloba o "conceito" e "abstrações" num todo fenômeno formado de fragmentações-invenções onde think texto ação hipótese a palavra-palavra e a palavra-em-contexto etc não tendem a "soluções fixas" mas movem-se abertamente em um mosaico supra-perceptivo q se estende ao próprio comportamento em play descontraído. ${ }^{436}$

Oiticica define a invenção de Ono como "INFINI-ELASTIC-XTENSION of existential elements, in space, in time, in behaviour" (uma extensão elástica e infinita de elementos existenciais no espaço, no tempo e no comportamento). A leitura de Grapefruit, conta o artista, causou-lhe uma sensação de "epifania" em relação a experiências de descondicionamento: o artista lembra que ao entrar em seu banheiro depois de ler o livro de Ono, sentira todos os objetos como liberados de suas funções e definições, episódio ao qual se refere em Cosmococa ONOBJECT ao incluir nos slides tanto o livro de Ono quanto What is a thing de Heiddeger.

É possível que o "meditar-andar" guarde ecos das apresentações de Yoko Ono que Oiticica presenciou em Nova Iorque. Em um dos Héliotapes, o artista relata a Augusto de Campos seu encantamento com as proposições de Yoko Ono com objetos e participantes, como "sucessões de máscaras precisas," possibilidade de mundos simultâneos. Oiticica relata no Héliotape que em uma das peças apresentadas, Yoko Ono conta a história de uma amiga - que, esclarece Oiticica, é sempre a própria Ono -- que parou de falar e definhou por isso. Do osso de sua perna então foi feita uma flauta de som encantador.

${ }_{435}$ OITICICA usa o termo "naturalista" como mímese ou representação.

${ }^{436}$ OITICICA, "Yoko Ono and Grapefruit", op. cit. 
Mas a flauta quebrara-se em mil pedaços, que a artista trazia guardados numa pequena caixa e iria passar de mão em mão pela platéia, para que todos chacoalhassem a caixa e assim, ela pudesse fazer um som, falar, com o osso da perna. Por fim, Ono pediu que alguém levasse a caixa para casa e todos os dias chacoalhasse-a para que sua amiga falasse.

Outra história contada por Ono envolvia um sacrifício: sua amiga decidira suicidarse de forma limpa e usara um balde para recolher o próprio sangue. Depois de contada a história, a artista apresentava um balde "com aspecto de novo" e fazia-o circular pelas pessoas da platéia. Oiticica percebeu o jogo com o tempo proposto por Ono: "o balde é o balde novo sem o sangue... quer dizer como se fosse... é o balde que é depois mas que é antes também. É o balde pré o suicídio, o sacrifício, o sangue, e pós também porque aquele é o balde; mas ali ele está novo outra vez... isso é incrível... toda coisa que ela fazia era assim..."

Esse tipo dobra do tempo que permite uma simultaneidade entre o que era antes e o que era depois aparece em um relato de Oiticica sobre o delirium ambulatorium. Oiticica acha na cidade blocos que construíam seu próprio pensamento, como a Mangueira, o subterrâneo, sua relação com as ruas do Rio e a música de Caetano Veloso, existindo simultaneamente na concretude de uma pedra:

\footnotetext{
Antes era a mitificação nos anos 60 , foi a construção da mitificação da rua, mitificação da dança, da mangueira, agora é um processo de desmitificação, junto com a mitificação, uma coisa já vem junto da outra: então eu pego assim pedaços de asfalto da Avenida Presidente Vargas, antes de taparem o buraco do metrô, todos os pedaços de asfalto que tinham sido levantados... Quando eu apanhei esses pedaços de asfalto, eu me lembrei que CAETANO uma fez fez uma música, que disse até que pensou em mim depois que fez a música, que falava o negócio da " escola de samba primeira da mangueira passa em ruas largas, passa por debaixo da Avenida Presidente Vargas”. Aí eu pensei assim: esses pedaços de asfalto... soltos, que eu peguei como fragmentos e levei para casa... agora, aquela avenida estava esburacada por baixo, e na realidade a estação primeira da mangueira vai passar por debaixo da Avenida Presidente Vargas... uma coisa que era virtual quando CAETANO fez a música, de repente se transformou num delírio concreto daquela coisa... o delírio ambulatório é um delírio concreto...
}

Um dos pedaços de asfalto que Oiticica encontrou nos escombros do metrô conformava-se ainda a outro bloco importante no mapa da imaginação de Oiticica pois 
tinha a forma da ilha de Manhattan. Com esse achado, Oiticica criou um novo lugar concreto, o jardim Kyoto-Gaudi no banheiro de seu ateliê.

O "Body-sense-play", que também aparece no texto sobre Grapefruit como "Bodyenvironment-play" não é nem corpo, nem ambiente, nem movimento, mas a junção dos três numa totalidade, como o meditar-andar faz com corpo, a cidade e o ambular.

Eu descobri o seguinte, a relação da rua com o que eu faço é uma coisa que sintetizo na idéia de 'Delírio Ambulatório'. O negócio assim de andar pelas ruas é uma coisa, que a meu ver, me alimenta muito e eu encontro, na realidade a minha volta ao Brasil, foi uma espécie de encontro mítico com as ruas do Rio, um encontro mítico já desmitificado. (...) ${ }^{437}$

Segundo Oiticica, Guy Brett revelara-lhe um "vínculo de paixão dentro da concepção de dreamtime". O delirium ambulatorium também é, para Oiticica, uma "paixão": "paixão meditar-andar (...) a mesma paixão que me fez deslocar o campo pictórico do quadro para o espaço, e a destruir o pictórico empobrecido de séculos para a proposição de um espaço-sítio novo”. Essa paixão, diz Oiticica, é a mesma paixão que levara Maliévitch a declarar "que a rejeição do velho mundo da arte fique inscrita nas palmas de sua mão.” A caminhada pelo Rio, então não é totalmente desmitificada: o herói cujos feitos o caminhar vai reatualizar é o artista inventor, cuja "paixão" (sofrimento e epifania) é a paixão de reinventar a arte, estabelecer novos ritos não estereotipados, fundar novos mitos.

O herói, é importante ressaltar, não é um caso particular como Maliévitch mas aquele que tem um comportamento aberto a conseqüências, "trágico." No lugar de um modelo exemplar, o mito desmitificado pede o retorno de um gesto-comportamento afirmativo:

Lancem mais!!! Quero dizer --> instaurem algo (novo portanto) instaurem o trágico (nietzscheano, se bem que nunca preso a tal condição ou definição!): em termos: aquilo que não se fixa num lugar de localidade de tempo/ situação/ culturação mas q shifts [desloca-se] daqui para o que gera consequência de consequência pra consequentização radicalizante de tudo o q

437 Áudio da entrevista de Hélio Oiticica a Ivan Cardoso, 1979. A transcrição dessa entrevista em Ivampirismo: o cinema em pânico contém imprecisões e no trecho aqui citado troca mitificação por mistificação. 
situa o agora-radical delas: não há 'fixar no q foi conquistado'ou no q estabelece conforto estável de conquista mesmo q maior: tô cá tô lá438

Sair do Rio para "desmitificar" é uma estratégia semelhante à do aborígene que sai da taba e vaga pela floresta em dreamtiming, em busca do novo: sair da taba, percorrer o exterior num enlevo de sonho e assim abrir-se, nem que apenas por alguns instantes, à moradia nômade no mundo.

Ainda que os escritos de Oiticica indiquem que o artista leu muito pouco da obra de Deleuze - apenas Nietzsche e a Filosofia é citado nos manuscritos que conhecemos sabemos que, como música, Oiticica captou "de ouvido" algo da filosofia deleuziana em conversas com Silviano Santiago que aconteceram na metade da década de $1970 .{ }^{439}$ Nós também aqui apenas iremos ecoar uma rápida nota sobre o nomadismo deleuziano ${ }^{440}$ : a distribuição nômade em Deleuze é uma "distribuição de errância e até mesmo de 'delírio' em que as coisas se desdobram sobre toda a extensão de um Ser unívoco e não dividido." ${ }^{441}$ Uma errância delirante, em "paixão meditar-andar", descondicionada dos rituais fixos, que integra vários elementos de existência, como corpo, ambiente e movimento-transmutação é o nomadismo que Oiticica propõe. A arte feita sob a ética do delirium ambulatorium abole a fixidez, substitui a representação de um evento parado pela estrutura, como o mapa, que pode ser sempre colocada em movimento num campo: "a visão de estrutura conduz à antiarte e à vida; a visão de eventos conduz à arte e ao distanciamento da vida." ${ }^{242}$ É também interessante notar que Oiticica traduziu ele mesmo para o inglês seu texto "Experimentar o Experimental" e deixou duas possibilidades para a tradução de "fios soltos do experimental": "loosen threads of the experimental" ou "scattered roots of the experimental". A segunda opção, "scattered roots" ["raízes espalhadas"] sugere um "rizoma". Vale repetir o que disse Oiticica em "O q Faço é

\footnotetext{
${ }^{438}$ OITICICA, Hélio. Sem título, 07/02/1975 em OITICICA, Hélio. ntbk2/73, p. 153.

${ }^{439}$ cf. OITICICA, Hélio. "Memorando Caju", 1979. Aqui vale lembrar um frase de Oiticica: "o q terá vindo antes ou depois?

${ }^{440}$ Ainda que Oiticica não tenha lido Deleuze tão frequentemente quanto o fez com Nietzsche, há um caminho a ser percorrido no labirinto de Oiticica a partir das teorias deleuzianas, trabalho que começa a ser feito em algumas pesquisas recentes, dentre as quais a tese já citada de Lisette Lagnado e trabalhos em andamento de Beatriz Scigliano Carneiro.

${ }^{441}$ DELEUZE, Gilles. Diferença e Repetição apud. ZOURABICHVILI, François. O Vocabulário de Deleuze. Rio de Janeiro: Relume-Dumará, 2004.

${ }^{442}$ Décio Pignatari citado por Oiticica em "Experimentar o Experimental", 1972, op.cit.
} 
MÚSICA", "na verdade há uma tal simultaneidade de raízes e veios q se erguem q não é possível saber o q veio antes ou depois: raízes criadas no ar a partir da INVENÇÃO." ${ }^{\$ 43}$

\section{Mundo-Abrigo e Bodywise em Newyorkaises}

Na década de 1970, com o anúncio da "desmitificação do parangolé," "444as capas tornam-se "mais abertas sem preocupação com 'significações corporais', 'nãocondicionamentos sensoriais', etc.”. O parangolé, dirá Oiticica, "não se reduz ao mythical nitty-gritty ${ }^{445}$ porque é play-concreção. Parangolé-síntese é não nostálgico de estados míticos." ${ }^{446}$

Desmitificados, dança e parangolé não irão mais re-atuar um momento original da criação artística - não há mais a possibilidade de um momento original, arrancaram-se as raízes --, mas se transformarão em "encontros-events de experimentalidade aberta sem aspirações a mito ou ritualidade do momento." A dança não será veículo para a expressão artística arcaica que vinha antes da terra, e sim extensão do próprio corpo, movimentação significativa do corpo no mundo, gerando a invenção, inaugurando a expressão artística a cada gesto: "liberação inventiva das capacidades de play." ${ }^{447}$ Do refúgio do mito, Oiticica passa para o refúgio do mundo -- mundo como definido pelo comportamento do corpo dos inventores-experimentadores. O que anteriormente chamamos de mito-abrigo cede lugar nos textos de Oiticica do início dos anos de 1970 à expressão "mundo-abrigo."

Com efeito, a obra de Oiticica admite uma leitura a partir dos abrigos que o artista elege para o aflorar da capacidade de invenção: "toda a obra de Hélio Oiticica parece ser, então, esta procura da poesia abrigada." ${ }^{448}$ Mais do que poesia abrigada, sugerimos que Oiticica procura um abrigo que permita que o corpo assuma um comportamento ("relação com o mundo"449) ciente de sua potencialidade total.

\footnotetext{
${ }^{443}$ OITICICA, Hélio. "O q Faço é MÚSICA”, 1979, op.cit.

${ }^{444}$ cf. OITICICA, Hélio. "Parangolé-síntese”, 1972, op.cit.

445 "mythical nitty gritty" são os detalhes e especificidades do mito.

446 OITICICA, Hélio. "Parangolé-síntese", 1972., op.cit.

447 OITICICA, Hélio. "Parangolé-Síntese", 1972, op. cit.

${ }^{448}$ MORAES, Frederico. "A Poesia Abrigada", Diário de Notícias, 05/10/1967.

${ }^{449}$ cf. OITICICA, Hélio. "Mundo-Abrigo", 21/07/1973. AHO 194.73. "Para chegar ao Mundo-abrigo (...) [é preciso] sentir-se livre (sem 'condições ideais') para assumir o experimental no comportamento (relações com o MUNDO)"
} 
"Bodywise", título de um bloco de Newyorkaises inaugurado em 1973, significa estar ciente do corpo. ${ }^{450}$

Em Newyorkaises, a decisão de construir um bloco chamado Bodywise precede a concepção do bloco Mundo-Abrigo ${ }^{451}$. Oiticica descreve a relação entre esses dois blocos como "assintótica": aproximam-se cada vez mais, sem se tocar, e deveriam ser compostos de notas, títulos e frases como que rascunhadas -- "como se fossem jotted down notes para abrir a participação do leitor”452.

Impressionado com a última cena da peça Nô traduzida por Haroldo de Campos, "Hagoromo", Oiticica escreve em seu bloco de notas sobre Bodywise várias páginas sobre o manto de plumas, ${ }^{453}$ sobre a dança que faz manto e anjo fundirem-se em um. A fusão manto-anjo sobe e dissolve-se no céu do céu. De manto-objeto que envolvia o corpo, o manto passa a manto-espaço:

O MANTO-OBJETO se dissolve em MANTO-ESPAÇO

isto é espaço-ambiente

o manto que deveria envolver o corpo se dissolve de objeto-MANTO para MANTO-espaço que

não só envolve como estabelece relações de simultaneidade entre corpo e espaço-ambiente

A Tennin without her robe

A bird without wings

How shall she climb the air? $?^{454}$

$\overline{450}$ cf. LAGNADO, Lisette. O Mapa do programa Ambiental. op. cit. p. 69. Wise, como a autora nota, significa estar bem informado, ciente de algo. Quando usado como sufixo, significa "em relação a" ( moneywise), ou "à maneira de" ou "em direção a" (clockwise). Em Oiticica, Bodywise é estar ciente do corpo e refletir sobre a arte em direção ao corpo, conhecendo a relevância do corpo.

${ }^{451}$ cf. OITICICA, Hélio. ntbk 2/73, p. 27.

${ }^{452}$ Ibid. p. 29

${ }^{453}$ Sobre Hagoromo, cf. tópico 2.6 Galáxia. Para os apontamentos de Oiticica sobre Hagoromo, cf. início de OITICICA, Hélio. ntbk 2/73 e uma versão datilografada desses apontamentos em "Para Bodywise seguindo-se ao excerto de H. De Campos Hagoromo (último episódio): Apontamentos", 22/06/1973 em PHO 203/73.

${ }^{454}$ OITICICA, Hélio. "Para Bodywise seguindo-se ao excerto de H. De Campos Hagoromo (último episódio): Apontamentos", 22/06/1973 em PHO 203/73. Na tradução de Haroldo de Campos, esse trecho de Hagoromo é: "Como um pássaro sem asas/ o anjo celeste sem o manto: / ao impulso do vôo faltam plumas." cf. CAMPOS, Haroldo de. Hagoromo de Zeami: o charme sutil, op. cit. p. 37. É interessante notar que a tradução para o inglês citada por Oiticica - provavelmente de Ezra Pound - fala em ar, em um vazio (A Tennin sem seu manto/ um pássaro sem asas/ como ela escalará o ar?) enquanto Haroldo de Campos enfatiza o impulso ao vôo, o que explica sua expressão "asa delta para o êxtase" usada para se referir ao parangolé de Oiticica. cf. CAMPOS, Haroldo de. "Asa Delta para o êxtase" op. cit. 


\section{Para Newyorkaises, Oiticica planeja unir os blocos Bodywise e Mundo-Abrigo}

com uma imagem que remete à última cena de Hagoromo: uma fotografia mostrando um homem atirando um arrastão de pesca para $\mathrm{o} \mathrm{ar}^{455}$, uma rede, trama ligada a seu braço, extensão de si, envolvendo um espaço no ar. ${ }^{456}$

O bloco Bodywise incluiria uma referência ao título do capítulo "Clothing" (Vestimenta) de Understanding Media, de Marshall McLuhan. O bloco Mundo-Abrigo citaria excertos de "Housing" (Moradia):

É óbvia a ligação de todas as teorias de MCLUHAN com a abordagem de MUNDO-ABRIGO: culmina com a formulação dele sobre/de ALDEIA GLOBAL TVizada e tem um manifesto q tem tudo o q quero em formulação nos capítulos Clothing e Housing de UNDERSTANDING MEDIA: o de Housing teria que ser todo citado para suprir argumentos. ${ }^{457}$

Vale a pena notar que Clothing (Vestimenta) e Housing (Habitação) são capítulos consecutivos no livro de McLuhan. O capítulo sobre vestimenta do livro de McLuhan defende que a sociedade americana de sua época passava por uma transição da ênfase no visual para a valorização dos aspectos tácteis das roupas. A intersecção entre o pensamento de Oiticica e esse trecho do livro de McLuhan existe, e está na valorização de todos os sentidos, não só da visão. Esse assunto, porém, já havia sido explorado por Oiticica em mais profundidade nas leituras que fez de Merleau-Ponty.

${ }^{455}$ Vemos aqui que Oiticica baseia-se mais na tradução de Hagoromo para inglês ("how shall she climb the air?") do que na tradução de Haroldo de Campos ("ao impulso do vôo faltam plumas"). cf. nota de rodapé anterior.

${ }^{456}$ cf. OITICICA, Hélio. ntbk 2/73, p. 29. Essa descrição que Oiticica faz da fotografia que queria para unir Bodywise e Mundo-Abrigo nos remeteu à obra de Tunga "Semeando Sereias", de 1988. A obra é acompanhada de um texto no qual o artista conta sua exploração de um estranho jardim, por onde corpos estavam espalhados. Mas tais corpos não estavam mortos. $\mathrm{O}$ artista anda por aquele jardim enquanto reflete sobre culturas, "o retorno, a recorrência, a obstinada volta" e decide cultivar seus próprios espécimes. Acha então uma cabeça em uma poça, sua própria cabeça. Na última foto da série, Tunga aparece na exata pose descrita por Oiticica, mas ao invés de lançar uma rede para o ar acima do mar como queria Oiticica, lança um emaranhado de fios que sustentam a cabeça. Essa rede são os longos cabelos da cabeça, que o artista tenta descartar no mar. Mas a cabeça fica presa em pedras e mariscos, batendo nas pedras. A "outra" cabeça do artista, "tendo atingido seu objetivo, flutua". Em Oiticica, a rede pesca um espaço, é extensão do corpo que quer se expandir para o espaço vazio e inexplorado do céu. Oiticica a princípio descreve que o mar deveria aparecer como continuação do céu e não como "solo". Depois, para evitar o mar-solo, resolve que a foto não mostraria o mar, mas "só o solto vôo do arrastão como um yoyo gigante ligado ao corpo/braço do homem e engolindo o espaço que abarca". Temos aqui duas fotografias do processo criativo: um que remete ao branco-sobre-branco suprematista, no qual o corpo, estendido na rede, quer abarcar um espaço novo; outro, que Tunga parece querer descartar, é uma cabeça arrancada de um corpo. cf. TUNGA, Tunga-Barroco de Lírios. São Paulo: Cosac\&Naif, 1997.

${ }^{457}$ OITICICA, Hélio. "Mundo-Abrigo", op. cit. 
Por outro lado, é fácil entender como o capítulo de McLuhan sobre habitação deve ter impressionado Oiticica no momento em que o brasileiro refletia sobre o Barracão. "Se a roupa é uma extensão da pele para guardar e distribuir nosso próprio calor e energia, a habitação é um meio coletivo de atingir o mesmo fim." ${ }^{\text {"458 }}$ A habitação, dirá McLuhan em seguida, é uma pele ou roupa coletiva e a cidades são extensões dos órgãos corpóreos. O homem tribal, diz ele, considerava-se um órgão do cosmos e

o corpo humano, no pensamento religioso dos índios, era ritualmente relacionado à imagem cósmica, e esta se assimilava em forma de habitação (...) a moradia era uma imagem tanto do corpo quanto do Universo (...) Tendo aceitado uma tecnologia analítica da fragmentação, o homem letrado não encontra acesso às estruturas cósmicas tão facilmente quanto o homem tribal. Prefere os espaços separados e compartimentados ao cosmos aberto. ${ }^{459}$

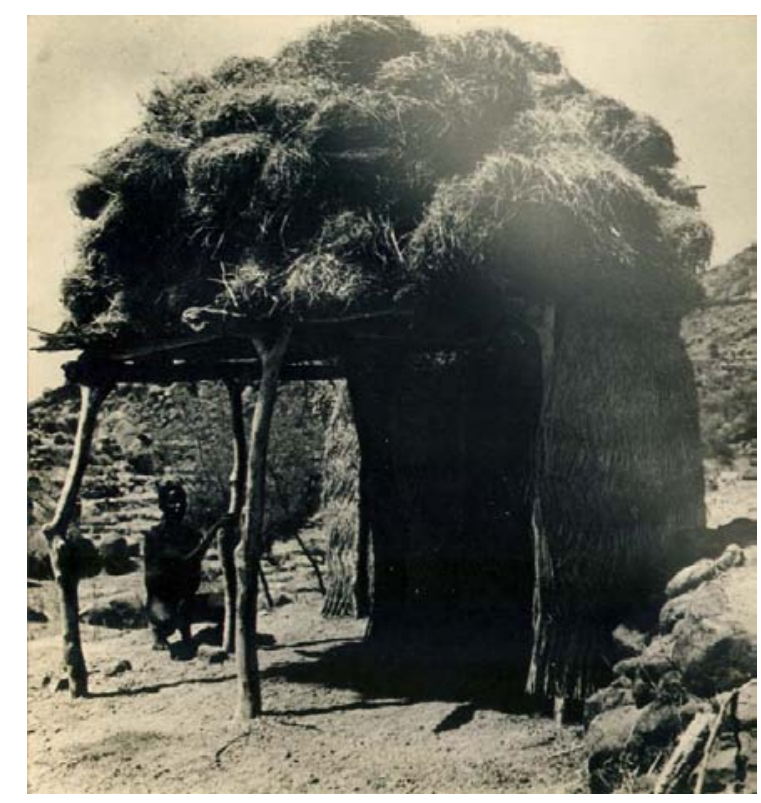

Fotografia do arquivo de Hélio Oiticica reproduzida no catálogo da Whitechapel Experience. O verso traz a anotação: "Kirdi Hut, Architecture without architects, Bernard Rudofsy, MOMA." AHO 2219.sd-p1

Oiticica também usou a casa primitiva para articular suas concepções sobre a integração corpo-ambiente. Os textos do catálogo da Whitechapel Experience evidenciam a relação que Oiticica estabelece entre a casa e o comportamento do corpo no mundo. O

${ }^{458}$ MCLUHAN, Marshall. Os meios de comunicação como extensões do homem (understanding media). Décio Pignatari (trad.). São Paulo: Cultrix, 1974. p. 144 (capítulo "Habitação")

${ }^{459}$ MCLUHAN, Marshall. op. cit., 145 
catálogo reproduz uma passagem de Tristes Tropiques, na qual Claude Lévi-Strauss descreve casas primitivas que

são menos edificadas do que entrelaçadas, tecidas, bordadas e desgastadas pelo uso; em lugar de esmagar o habitante sob a massa indiferente das pedras, elas reagem com flexibilidade à sua presença e aos seus movimentos; (...) A aldeia ergue-se à volta de seus ocupantes como uma leve e elástica armadura; está mais perto dos chapéus de nossas mulheres do que das nossas cidades. ${ }^{460}$

A casa maleável descrita por Lévi-Strauss é um abrigo flexível semelhante ao que Oiticica idealizava para o Barracão. Igualmente amparado pelo exemplo de sociedades primitivas, McLuhan articula a união corpo-casa-roupa. Trabalhando com o conceito de "mundo erigindo mundo" e com uma galáxia de inventoresexperimentadores, Oiticica encontra nas palavras de McLuhan uma maquete para o Mundo-abrigo. Cada inventor é um órgão (ou célula) de Mundo-Abrigo.

Oiticica estabelece também uma diferença entre o mundo como abrigo e o mundo como "gadget" - palavra que incorpora a seu vocabulário a partir de leituras dos livros de McLuhan. O mundo como gadget é o uso do mundo como aparelho utilitário, a ser usado para alguma finalidade de subsistência. É preciso, segundo Oiticica, incluir isso, mas ir além. Usar o mundo como playground, como campo para um lazer prazeroso. "MUNDO-SHELTER é o MUNDO tomado como PLAYGROUND e onde o comportamento individual (- coletivo) não se quer adaptar a patterns gerais de trabalholazer mas a experimentações de comportamento mesmo q essas nasçam fragmentadas e isoladas (o q deve acontecer) ${ }^{\prime 461}$.

Barracão, diz Oiticica nesse texto, não pôde ser feito por causa das circunstâncias em vigor no Brasil, diluidoras de qualquer comportamento experimental, mas, corroborando a importância do retorno em seu pensamento, Oiticica insiste no caráter adaptável do Barracão e na possibilidade de que ele seja erigido sem limitações de lugar ou tempo. Barracão "é experiência q deve sofrer etapas q tem q nascer desaparecer renascer e transformar-se segundo circunstâncias de ordem geral’".

\footnotetext{
${ }^{460}$ Catálogo Whitechapel Experience. Tradução segundo o fac-símile do catálogo reproduzido em OITICICA, Hélio. Aspiro ao Grande Labirinto, op.cit..

${ }^{461}$ OITICICA, Hélio. "Mundo-abrigo", op. cit.
} 


\section{Rock no abrigo do Norte: Gimme Shelter}

Mundo-Abrigo é tanto um bloco de Newyorkaises quanto uma "proposição de experimentalidade livre" conceituada por Oiticica em texto de $1973 .{ }^{462}$ Mundo-abrigo é a “chegada gradativa a uma experimentação coletiva", síntese de várias outras experiências com o coletivo - a vontade de um novo mito, Barracão, parangolés nas ruas de Nova Iorque, ninhos. Referindo-se à Sartre, Oiticica identifica uma emergência do coletivo:

é uma coisa do Sartre quando ele fala da posição do artista e do criador no mundo atual, que a gente está numa passagem do individual, de valores individuais e valores individualistas para o coletivo, então na realidade a gente está dividido, entre o mais individual e ao mesmo tempo imergindo nessa emergência do coletivo. ${ }^{463}$

A frase de Sartre vem do livro sobre Jean Genet: "estamos todos divididos, como ele [Jean Genet], entre as exigências de uma moral herdada da propriedade individual e uma moral coletivista em formação" ${ }^{464}$. O fato de Oiticica ter detectado uma idéia capaz de articular sua aspiração a uma nova forma de sociabilidade em um livro sobre um poeta-ladrão é relevante. A marginalidade legal esteve sempre vinculada às reflexões de Oiticica sobre a marginalidade do artista, desde o bólide Cara de Cavalo, de 1966, homenagem a seu amigo criminoso executado brutalmente pela polícia. ${ }^{465}$ No catálogo da exposição na Whitechapel Gallery, Oiticica faz uma homenagem a Cara de Cavalo, homenagem à "revolta social individual: a dos chamados bandidos (...) há um contraste, um caráter ambivalente no comportamento do homem marginalizado: ao lado de uma grande sensibilidade está um caráter violento, e muitas vezes, em geral, o crime é uma busca desesperada por felicidade." Oiticica nesse texto condena condicionamentos

${ }^{462}$ OITICICA, Hélio. "Mundo Abrigo", op.cit.

${ }^{463}$ Áudio da entrevista de Hélio Oiticica a Ivan Cardoso, 1979.

${ }^{464}$ SARTRE, Jean-Paul. Saint Genet: ator e mártir. Petrópolis: Vozes, 2002. p. 65. A primeira publicação, em francês, é de 1952.

${ }^{465}$ Para detalhes sobre a história de Cara de Cavalo, cf. CARNEIRO, Beatriz Scigliano. Relâmpagos com Claror. op. cit. Carneiro pesquisou os jornais da época para recontar a história de Cara de Cavalo. Chama a atenção a menção a um poema de Clarice Lispector a respeito da execução pela polícia de outro criminoso, Mineirinho: “...há alguma coisa que, se me faz ouvir o primeiro e o segundo tiro com alívio de segurança, no terceiro me deixa alerta, no quarto me desassossega, o quinto e o sexto me cobrem de vergonha, o sétimo e o oitavo eu ouço com o coração batendo de horror, no nono e no décimo minha boca está trêmula, no décimo-primeiro digo em espanto o nome de Deus, no décimo-segundo chamo meu irmão. O décimoterceiro tiro me assassina - porque eu sou o outro. Porque eu quero ser o outro." 
sociais e afirma que a violência é justificável como forma de revolta, desde que não seja uma revolta opressiva. Não há uma defesa do criminoso nos textos de Hélio Oiticica. Há uma condenação de tudo o que é opressor, daquilo que sufoca brutalmente as forças contra-atuantes. A posição libertária de Oiticica "só compreende a revolução baseada no respeito às singularidades e ainda numa união de todos os explorados, mesmo os marginais. ${ }^{~} 466$

A marginalidade como resistência a uma ordem estabelecida também aparece nos textos de Oiticica nas citações do livro Woodstock Nation, de Abbie Hoffman, autor que se define como um "revolucionário cultural que acredita que a violência é inevitável no confronto entre uma cultura emergente e uma cultura em decadência." ${ }^{\$ 67}$ Oiticica, lembremos também declarara não ser pela paz, achá-la "inútil e fria - como pode haver paz, ou se pretender a ela, enquanto houver senhor e escravo!" 468

Hoffman define uma nação virtual, a "Woodstock Nation", vivendo no mesmo território que a sociedade norte-americana, que ele nomeia de "Pig Nation" (Nação dos porcos). Escrito enquanto o autor se recuperava de uma overdose que o fez abandonar o festival de Woodstock um dia antes de seu término, o livro relata suas posições políticas e estratégias de organização de grupos de jovens (que formam a "Woodstock Nation") em demonstrações contra a guerra do Vietnam, contra a opressão das comunidades negras, contra um sistema educacional que em sua opinião canalizava os jovens para uma sociedade corrupta e impessoal ou contra o "trabalho desumanizador que o sistema econômico capitalista exige". Durante a apresentação do The Who em Woodstock e já no início da "bad trip" que o levaria a abandonar o festival no sábado, Abbie Hoffman invadiu o palco, tomou o microfone para falar ao público em defesa de John Sinclair ${ }^{469} \mathrm{e}$ foi agredido pelo guitarrista da banda. Além desse incidente, seu livro relata que durante o festival aconteceram 3 mortes e milhares de ferimentos ou ocorrências de overdoses.

\footnotetext{
${ }^{466}$ ZILIO, Carlos. "Da Antropofagia à Tropicália” in O Nacional e o Popular na Cultura Brasileira. NOVAES, Adauto (org.) São Paulo:Brasiliense, 1982. p. 35

${ }^{467}$ HOFFMAN, Abbie. Woodstock Nation, New York: Random House, 1969, p 153. Orgulhoso de ser um marginal em um sistema que desprezava, o autor sugere que, para informações mais detalhadas sobre sua biografia, consulte-se os arquivos do FBI.

${ }^{468}$ OITICICA, Hélio. "Posição Ética" em Aspiro ao Grande Labirinto, op.cit. p. 82

${ }^{469}$ John Sinclair, escritor da imprensa alternativa de Detroit, foi sentenciado a 10 anos de prisão em 1969, por oferecer cigarros de maconha a policiais a paisana.
} 
No sábado, segundo Hoffman, a população da fazenda de Bethel constituía a segunda maior cidade no estado de Nova Iorque com 400.000 pessoas assistindo o festival e infraestrutura totalmente insuficiente para atendê-las, principalmente depois de uma grande chuva que transformou a fazenda em uma ilha de lama. Hoffman transcreve em seu livro trechos de editorais de grandes jornais que elogiavam o comportamento solidário e "unido na calamidade" que envolveu tanto os fãs do rock quanto a população do entorno da fazenda, que passou a fornecer água potável e comida ao público do festival, como acontece depois de grandes desastres naturais. Consumidor de maconha e LSD, Hoffman fala nesse livro de sua relação conflituosa com traficantes de drogas ("eles são afinal de contas capitalistas, mas também são foras-da-lei”) e com os empresários do espetáculo que organizaram o festival de Woodstock.

Além da clara afinidade entre Oiticica e Hoffman no que concerne ao trabalho alienado (Hoffman, por sinal, foi aluno de Herbert Marcuse na Brandeis University ${ }^{470}$ ) e a questão do uso de drogas, Oiticica aproxima a Woodstock Nation de Éden: "Mundoabrigo é proposição assim como Woodstock Nation, como Éden [:] proposição de experimentalidade livre. ${ }^{471} \mathrm{O} E$ Éden, como já argumentamos, marca a abertura para a invenção de um novo mito desmitificado, proposição de estruturas abertas. Como articulado por Hoffman, "a única maneira de apoiar uma revolução é fazer a sua própria." ${ }^{\prime 42}$ Éden oferece, como Woodstock Nation, uma proposta a ser experimentada por cada um a sua maneira. A estrutura comum às duas propostas é a criação de condições para o enfrentamento individual do condicionamento imposto pelo trabalho alienado. Para Hoffman, "a revolução política leva as pessoas a apoiarem outras revoluções ao invés de envolvê-las em fazer suas próprias revoluções. A revolução cultural requer que as pessoas mudem suas formas de viver e ajam em revolução"473

"Gimme Shelter", a música dos Rolling Stones, é para Oiticica o anúncio da necessidade de um abrigo que proteja o comportamento experimental ameaçado de dissolver-se $\mathrm{s}^{474}$. A letra da música dos Rolling Stones é para Oiticica mais um achado,

\footnotetext{
${ }^{470}$ HOFFMAN, Abbie. op. cit., p. 152.

${ }^{471}$ OITICICA, Hélio. "Mundo-abrigo", op. cit.

${ }^{472}$ HOFFMAN, Abbie. op. cit., p. 57

${ }^{473}$ HOFFMAN, Abbie. op. cit., p. 7

${ }^{474}$ OITICICA, Hélio. "Mundo-Abrigo", op. cit.
} 
como um pedaço de asfalto, pedra encontrada no meio de outros rocks, a ser usado livremente.

Os lyrics de GIMME SHELTER:quero falar neles não como investigador estético (that would be a joke!) mas para intencionalmente utilizá-los com sample de argumentos que vêm ao encontro do que quero explicitar - não me interessam as "intenções originais" q os criaram (os lyrics): nem mesmo os próprios criadores saberiam (ou não nos interessa o q eles pensam q sabem sobre isso) essas razões, etc. ${ }^{475}$

"War, children, is just a shot away" [Guerra, crianças, está a um tiro de distância] gritam os Stones, e Oiticica atrela a palavra "children" aos experimentadores, àqueles ameaçados de extinção que querem andar pelo mundo descobrindo coisas como uma criança, que alcança com os objetos do mundo o seu "espaço potencial" ${ }^{476}$

“GIMME SHELTER não é música cantada (...) é grito q é de multidão: marcha vitoriosa pelas ruas experimentais da liberdade (...) o q é gritado é como q invocação diabólica apocalipse q não é crítica de mundo é o anjo coletivo ROCKWOODSTOCK anunciando tempos-destino". De body para every $\underline{b o d y}$ : a ameaça (a storm is threatening my very life today/ uma tempestade ameaça minha própria vida hoje) não é ameaça a uma vida individual, diz Oiticica, mas a "vida-children coletiva". O que está ameaçado de extinção não é a espécie humana mas a experiência coletiva livre; a ameaça é o extermínio do exercício experimental da liberdade "q não se refere mais somente à tarefa do artista (necessária) (...) mas a uma condição de liberação coletiva q é encarnada no conceito geral de children". ${ }^{477}$

\footnotetext{
${ }^{475}$ Ibid.

${ }^{476}$ cf. WINNICOTT, Donald. W. O Brincar e a Realidade. Rio de Janeiro: Imago Editora, 1975. Ao tentar identificar a localização da experiência cultural na mente humana, Winnicott conclui que ela não se localiza nem no espaço psíquico interno nem no espaço externo. Assim, ele define um terceiro espaço, o espaço potencial, onde localiza a brincadeira e a experiência cultural. A experiência cultural é para Winnicott continuidade da brincadeira. O espaço potencial localiza-se entre o indivíduo e o meio ambiente, e Winnicott ressalta que o "meio ambiente" é o desenvolvimento da relação do indivíduo com um objeto que originalmente conduziu o bebê com segurança pela experiência de frustração da onipotência: "esse espaço potencial encontra-se na interação entre nada haver senão eu e a existência de objetos e fenômenos situados fora do controle onipotente(...) Todo objeto é um objeto 'descoberto'. Dada a oportunidade, o bebê começa a viver criativamente e a utilizar objetos reais, para neles e com eles ser criativo. Se o bebê não receber essa oportunidade, então não existirá área em que possa brincar, ou ter experiência cultural, disso decorrendo que não existirão vínculos com a herança cultural, nem contribuição para o fundo cultural." (p139, 141)

${ }^{477}$ OITICICA, Hélio. "Mundo-Abrigo", op. cit.
} 
Rockeificar ajuda a desmitificar: dançar o samba à altura de um passista da Mangueira exige iniciação, aprendizado, técnica. O rock, ao contrário, é para Oiticica a "dança que se dança", dança planetária, que independe do pertencimento a uma cultura. Qualquer um dança rock, dança sozinho, sem par, sem coreografia. Rockeificar é participar da música e da dança, ser um performer e não um espectador. Platéia rockeificada é a platéia que participa com o corpo: “o ROCK nunca é background sound: é loud grita sua participação-corpo a todo momento: é não contemplativa: elétrica!"478 Rockeificado é o artista trágico que tem "substância criador[a] de mundo":

HENDRIX --> instauração do trágico (q nada tem a ver com RESTAURAÇÃO DA TRAGÉDIA q os diluidores "explicadores" de NIETZSCHE tomam como algo NIETZSCHEANO e não é !: NIETZSCHE foi o anunciador da INSTAURAÇÃO DO TRÁGICO q IN-CORPORA comportamento-mundo-vida numa só genealogia cujo ápice é a concepção do ARTISTA TRÁGICO no qual as conseqüências mais extremas levam a outras etc. Tornando vãs e sem sentido as costumeiras gratificações intelectuais/culturais de alto status do artista-status q mesmo num nível alto de criatividade e gênio já fica inadmissível diante do ARTISTA TRÁGICO: este tem substância criador ${ }^{479}$ de mundo. O outro já era!: HENDRIX/ ROCK IRREVERSÍVEIS: como ver MÚSICA como "uma das artes"?: ou HENDRIX como "guitarrista de gênio?: ou pior e mais burro ver ROCK como "gênero de música popular ou uma dança característica"!: (...) e é tão relevante quanto saber que MALÉVITCH-SUPREMATISMO-BRANCO NO BRANCO não são pintor-movimento artístico-obra chave ${ }^{480}$

\footnotetext{
${ }^{478}$ OITICICA, Hélio. ntbk 1/73, p. 15

${ }^{479}$ Mantivemos essa palavra de acordo com o que Oiticica escreveu na carta citada, mas provavelmente ele quis dizer que o artista trágico tem substância criadora de mundo.

${ }^{480}$ OITICICA, Hélio. Carta para Mary e Mario Pedrosa, 28/02/1975. AHO 1411.75
} 


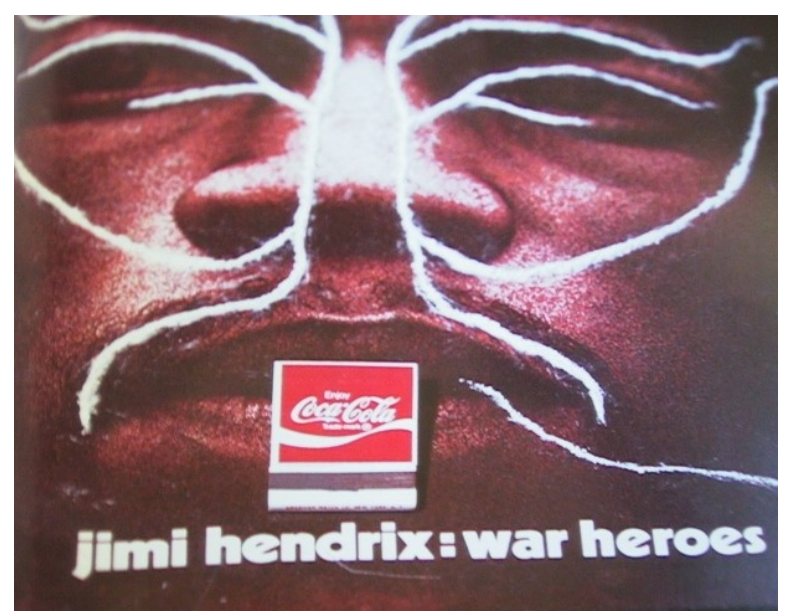

Hélio Oiticica e Neville D'Almeida - Slide de Block experiments in Cocmococas, CC5 Hendrix War, 1973.

O trágico, para Oiticica, é aquilo que não se fixa, que gera "conseqüência de conseqüência" ${ }^{481}$ e ao mesmo tempo abole a fixidez da linearidade. O trágico é como um mapa - e não um modelo mítico -- de movimento multi-dimensional que a cada vez que for repetido gerará um jardim novo, como o delirium ambulatorium e o jardim KyotoGaudi.

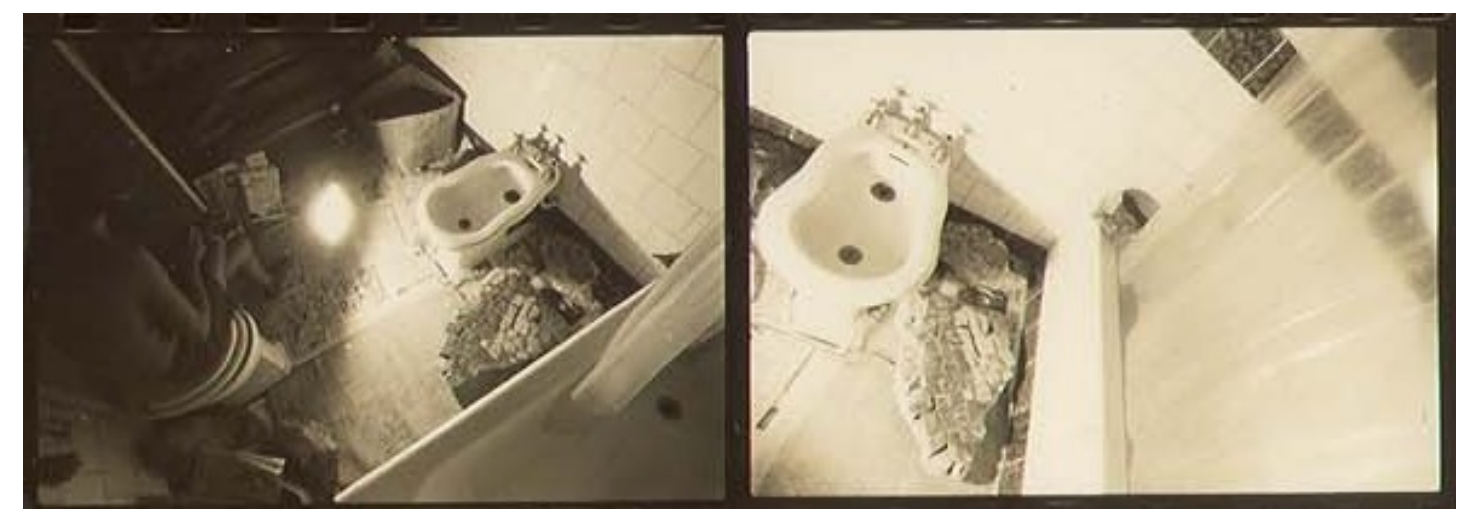

Jardim Kyoto-Gaudi no banheiro do ateliê da R. Ataulfo Alves, com blocos achados na Av. Presidente Vargas

Como em Nietzsche, essa noção do trágico alia a festa, o delírio dionisíaco Hendrix destruindo sua guitarra -- à repetição, que Oiticica chama de "conseqüência":

${ }^{481}$ OITICICA, Hélio. Anotação de 7/02/1975 em OITICICA, Hélio. Ntbk 2/73, p. 153. 
repetição do aparecimento do singular. Como em Nietzsche é na música que Oiticica identifica melhor o artista trágico - a essência da tragédia, segundo Nietzsche, não estava na narrativa mítica, mas no coro $^{482}$, um além-participador que Oiticica reconhece na "platéia rockeificada", os "young maniacs." 483

O coro que acompanha Mick Jagger em Gimme Shelter e grita por um abrigo é, para Oiticica, um "grito multidão, como se toda a WOODSTOCK NATION gritasse". A música dionisíaca -- e o coro da tragédia -- deixa de ser relacionada prioritariamente ao samba. É o rock que responderá agora a questão que persegue Oiticica desde os tempos da Mangueira: a importância do corpo na origem da criação artística:

o ROCK p. ex. se tornou o mais importante para minha posta em cheque dos problemas chave da criação (...) o ROCK é a síntese planetário-fenomenal dessa descoberta do corpo q se sintetiza no novo conceito de MÚSICA como totalidade-mundo criativa em emergência hoje: JIMI HENDRIX DYLAN e os STONES são mais importantes para a compreensão plástica da criação do q qualquer pintor depois de POLLOCK!: A MENOS Q QUEIRAM OS ARTISTAS DITOS PLÁSTICOS CONTINUAR REMOENDO AS VELHAS SOLUÇÕES PRÉDESCOBERTA DO CORPO AO INFINITO: E NÃO É O Q ESTÁ ACONTECENDO DE CERTA FORMA?: NÃO SERIA ESSA SÍNTESE MÚSICA - TOTALIDADE PLÁSTICA A Q TERIAM CONDUZIDO EXPERIÊNCIAS TÃO DIVERSAS E RADICALMENTE RICAS NA ARTE DA PRIMEIRA METADE DO SÉCULO QUANTO AS DE MALEVITCH KLEE MONDRIAN BRANCUSI?: e porque é q a experiência de HENDRIX é tão próxima e faz pensar tanto em ARTAUD?: mas isto fica para outro texto maior noutra parada já q o assunto é bem complexo e aponta para o q NIETZSCHE concebeu como sendo o artista trágico ${ }^{484}$

A MÚSICA de Oiticica é um todo, como a cor branca, que advém de uma síntese feita com as pesquisas construtivistas de expansão a arte para o corpo-ambiente e o movimento livre, não-ritualístico, de caráter coletivista e delirante da dança do rock. A MÚSICA compreende ainda as conseqüências éticas dessa junção que retumba no corpo e portanto altera seu comportamento no mundo.

\footnotetext{
482 cf. KOSSOVITCH, Leon. op. cit., p. 174

${ }^{483}$ OITICICA, Hélio. ntbk 1/73 p.7

${ }^{484}$ OITICICA, Hélio. “O q Faço é MÚSICA”, 1979, op.cit. Grifo acrescentado pela autora.
} 
Espécie de além-do-homem Nietzschiano ${ }^{485}$, o inventor é o artista trágico "que não existia antes em plenitude e só agora começa a emergir na sua inteireza e totalidade" ${ }^{\prime 46}$. Ele habita o Mundo-Abrigo, Barracão de dimensões planetárias no que concerne espaço e tempo, vive o mundo como campo experimental, assim como uma criança em seu playground. Para Oiticica, a invenção estaria na vida, no efêmero, no cotidiano, e não nas instituições ou na fixidez dos comportamentos ritualizados.

Desmitificado dos "mitos burgueses", surge um novo indivíduo.

o

INVENTOR é o único q tem relevância:

é o único capaz de ser o protótipo-

modelo para o indivíduo q deverá emergir no processo de coletivização

emergente do qual fala SARTRE no livro sobre GENET:

diz SARTRE -> "Dividimo-nos

como ele (GENET), entre as exigências de uma ética herdada da propriedade

individual e uma ética coletivista em processo de formação" $\downarrow$

O INVENTOR

EMERGE DE MODOS DIFERENTES A CADA DIA CADA VEZ MAIS LIGADO A UM PROCESSO

COLETIVISTA DE AÇÃO $\downarrow$

O INVENTOR INVENTA O NOVO NO DIA

DO DIA $\downarrow$

ELE FAZ O NOVO DIA! ${ }^{487}$

"Time is on my side" (o tempo está a meu favor), diz a letra da canção dos Rolling Stones citada por Oiticica em seus notebooks ${ }^{488}$ : o passar do tempo torna o retorno inevitável, e faz o momento presente "prelúdio ao novo", etapa de um processo de "emergência irreversível do NOVO." 489

\footnotetext{
${ }^{485}$ Em um trabalho anterior, analisei as capas parangolé dos anos 1960 como "capas do super-homem" em referência tanto ao "além-do-homem" Nietzschiano quanto ao personagem das histórias em quadrinho, herói de uma "mitologia pop". cf. BRAGA, Paula. "Hélio Oiticica and the Parangolés: (Ad)Dressing Nietzsche's Übermensch". Third Text, vol 17, 1, 2003, pp. 43-52.

${ }^{486}$ OITICICA, Hélio. "O q Faço é MÚSICA", op. cit.

${ }^{487}$ OITICICA, Hélio “Anotações Conta-Gota”, 1978. No Arquivo HO há uma versão datilografada e uma versão manuscrita desse texto. A versão manuscrita parece-nos mais correta. Provavelmente o texto não foi datilografado por Hélio Oiticica. cf. AHO 090.78-p1 a p3 e AHO 091.78-p14 a p20 e p23 a p24

${ }^{488}$ OITICICA, Hélio. ntbk 1/73, p.8

${ }^{489}$ OITICICA, Hélio. "Texto feito a pedido de Daisy Peccinini...", op. cit.
} 
Mosquito da Mangueira, abrigado por uma capa de super-homem ${ }^{490}$, brinca com a terra que está dentro do bólide. Revolução afirmativa, o que Oiticica propõe só precisa de tempo para crescer e "calor ambiental" ${ }^{\text {"91 }}$ para fermentar, possibilidade de expansão. O tempo e o calor ambiental garantem para Hélio Oiticica o retorno do singular.

O tempo já está dado. As propostas ambientais de Hélio Oiticica propõem uma pele coletiva que mantém o calor. Oiticica, assim, fermenta a transformação e a arte em sua plenitude construtivista: totalidade da vida.

\footnotetext{
${ }^{490}$ BRAGA, Paula. "Hélio Oiticica and the Parangolés: (Ad)dressing Nietzsche's Übermensch", op. cit. ${ }^{491}$ Expressão que Oiticica usa no texto "A Trama da Terra que Treme: o sentido de vanguarda do grupo baiano", op. cit.
} 


\section{Conclusão}

“As pessoas normais se tornam artistas plásticos. Eu me tornei um declanchador de estados de invenção." ${ }^{492}$ Aos risos, em conversa com Ivan Cardoso em 1979, Oiticica identifica sua diferença.

A arte no pensamento de Oiticica parece ser uma malha densa multi-dimensional de estados de invenção, sem começo nem fim, estados interligados por fios que aparecem e somem, chegando e partindo de cada estado: um labirinto dinâmico, com corredores intermitentes em várias alturas. O inventor percorre aos risos os estados de invenção, em delírio ambulatorial. Assim, seu movimento é sempre de retirar arte do "plano", criar as condições para que ela escape para outro estado. E mais: o artista inventor quer declanchar o estado de invenção no participador. ${ }^{493}$ Para isso, nenhuma transcendência é necessária pois o campo que abriga a malha de estados de invenção é o "corpo-ambiente: o dia-a-dia como campo experimental aberto." ${ }^{494} \mathrm{O}$ nome desse campo é Mundo-abrigo.

Oiticica não produzia obras, mas reinventava a arte em sucessivos ciclos de absorção de leituras e vivências. Suas proposições são "alimento do novo", um impulso para que a arte passe para outro estado. Quando faz mais um parangolé ou mais um bólide, Oiticica está reinaugurando aquele estado de invenção em outro ponto do campo. A soma de obras em um mesmo estado de invenção é de um sedentarismo inócuo para arte.

O trajeto de Oiticica pelos estados de invenção começou explorando o corpo com foco em seu aparato sensorial nas experiências com a cor do final da década de 1950 e chegou ao comportamento ético do corpo, no ponto de proposição de um novo indivíduo, o inventor, cuja conduta é tão difícil de apontar quanto seria impossível descrever a vida do além-do-homem de Nietzsche. Ser um inventor exige um grau de descondicionamento que Oiticica só identifica em alguns artistas, como Joyce em seu desligamento "da terra Irlanda pra q pudesse experimentar MUNDO e tornar a

${ }^{492}$ Áudio da entrevista de Hélio Oiticica a Ivan Cardoso, 1979.

${ }^{493}$ Ibid.

${ }^{494}$ OITICICA, Hélio. "Mundo Abrigo”, op.cit. 
IRLANDA do dia-a-dia simultânea à Ítaca odisséica e às possibilidades infinitas nãocondicionadas dos dias-a-dias simultâneos-contíguos-entrelaçantes"495. Mas até o final de sua vida Oiticica ainda exercitava o pensamento da possibilidade de existência do inventor como novo indivíduo, limite da arte que Oiticica não teve tempo de declanchar.

Outros estados de invenção, porém, foram ativados e aguardam conseqüências. É possível retomar e dar conseqüência às experiências com a cor sem que isso signifique retrocesso pois numa malha densa de estados de invenção não há linearidade. O lazer descondicionado, o quasi-cinema, labirintos públicos: tudo é prelúdio ao novo quando não há um ponto inicial.

"Gente + Tempo + Possibilidade de expansão", escreveu Oiticica ao falar da célula matriz do Barracão: "algo espreita a possibilidade de se manifestar e aguarda --> ultraguarda." ${ }^{496}$

${ }^{495}$ OITICICA, Hélio. "Mundo Abrigo". op.cit.

${ }^{496}$ OITICICA, sem título, PHO 0384/69. Publicado como "LDN" (abreviação de "London") em OITICICA, Hélio. Aspiro ao Grande Labirinto, op.cit., p. 117. 


\section{Bibliografia}

\section{Manuscritos de Hélio Oiticica}

AHO - Arquivo HO, Rio de Janeiro: Projeto HO, 2006

PHO - Programa HO, LAGNADO Lisette (ed.) São Paulo: Itaú Cultural; Rio de Janeiro:

Projeto HO, 2002, disponível em

http://www.itaucultural.org.br/aplicexternas/enciclopedia/ho/

OITICICA, Hélio. Sem título, s. d., AHO 0279.sd e PHO 0279/55.

OITICICA, Hélio. "Cor-Tempo", 1959. PHO 0017/59.

OITICICA, Hélio. Sem título, setembro de 1960. AHO 121.60-p16 e p17.

OITICICA, Hélio. Sem título, novembro de 1960. AHO 0121.60-p30.

OITICICA, Hélio. Sem título, c. 1960. PHO 0182/59 e PHO 0014-59.

OITICICA, Hélio. "Cor, Tempo e Estrutura", sem data, c. 1960. AHO 015.60.

OITICICA, Hélio. "Projeto Cães de Caça e Pintura Nuclear", s.d. AHO 0024.61.

OITICICA, Hélio “Como cheguei a Mangueira”, sem data, AHO e PHO 1863/sd.

OITICICA, Hélio. "Posição Ética”, 1966. AHO 253.66.

OITICICA, Hélio. Sem título, 1967. AHO e PHO 0018/67.

OITICICA, Hélio, Sem título, 18/03/67, AHO 109.67.

OITICICA, Hélio. “À Busca do Suprasensorial”, 1967. PHO 192/67.

OITICICA, Hélio. “A Criação Plástica em Questão: Respostas”, 1968. AHO 0159.68 e PHO 0159.68.

OITICICA, Hélio. "A Trama da Terra que Treme (O Sentido de Vanguarda do Grupo Baiano)". AHO 280.68.

OITICICA, Hélio. Sem título, 1968 (título atribuído em AHO: "Critério para o

Julgamento das Obras de Arte Contemporânea"). AHO 133.68.

OITICICA, Hélio. “A obra, seu caráter objetal, o comportamento”. AHO 160.68

OITICICA, Hélio, "Barracão” AHO 452.69.

OITICICA, Hélio. "Tropicália: the image problem surpassed by that of a SYNTHESIS", 1969. AHO 0350.69.

OITICICA, Hélio. “Tropicália, the New Image”. AHO 0535.69.

OITICICA, Hélio. “As Possibilidades do Crelazer”,1969. AHO 0305.69.

OITICICA, Hélio. "Barracão Idea”, 1969. AHO 1664.69.

OITICICA, Hélio. "The Senses Pointing towards a New Transformation", 1969. PHO 0486.69.

OITICICA, Hélio. "Bob Dylan e o 'Environment' Ilha de Wight”, 01/09/1969, AHO 457.69.

OITICICA, Hélio. “Londocumento”, 1969. AHO 304.69.

OITICICA, Hélio. "Subterrânia", 1969. AHO 382.69.

OITICICA, Hélio. "Subterrânia 2", sem data. AHO 382.69-a-p1. 
OITICICA, Hélio. Sem título, 1969 (Título atribuído em Aspiro ao Grande Labirinto: "LDN"). PHO 0384.69.

OITICICA, Hélio. "Experiência Londrina - Subterrânea”, 1970. AHO 0290.70.

OITICICA, Hélio. "Brasil Diarréia", 1970. PHO 0328.70.

OITICICA, Hélio. Sem título, 1970 (Título atribuído em AHO: "Meu trabalho é subterrâneo"). AHO 307.70.

OITICICA, Hélio. "HO NYK sept. 1, 71: anotações para serem traduzidas para inglês: para uma próxima publicação", 1971. PHO 0271.71.

OITICICA, Hélio. "Subterranean Tropicalia Projects", 1971. AHO 269.71.

OITICICA, Hélio. "Projects", 1971. Arquivo HO 266.71.

OITICICA, Hélio. "Notas", 10/06/1971. AHO 0278/71-p1.

OITICICA, Hélio. "Experimentar o Experimental", 1972. PHO 0380.72.

OITICICA, Hélio. "LEORK”, 1972. AHO 0262.72.

OITICICA, Hélio. "Homage to my Father", 1972. AHO 451.72.

OITICICA, Hélio. "Parangolé Síntese”, 1972. AHO 201.72.

OITICICA, Hélio. "Yoko Ono and Grapefruit", 1973 AHO 0292.73 e AHO 189.73 p. 47 a p50.

OITICICA, Hélio. “ntbk1/73", 1973. AHO e PHO 316.73.

OITICICA, Hélio. "ntbk2/73", 1973. AHO e PHO 189.73.

OITICICA, Hélio. "Rap in Progress", 1973. PHO 0393.73.

OITICICA, Hélio. "Cosmococa: as drafted and synthetized for inclusion in

Newyorkaises", outubro/1973 a fevereiro/1974. PHO 0311.73.

OITICICA, Hélio. "Übercoca”, 1973 AHO 0267.73-p2.

OITICICA, Hélio. "Mundo-Abrigo", 1973. AHO 194.73.

OITICICA, Hélio. "Riscado etc continuação", 1974. AHO 0180.74.

OITICICA, Hélio. Sem título, 1974 (título atribuído em PHO: "Lendo Gertrude Stein"). PHO 315.74.

OITICICA, Hélio. "Cosmococa- Programa in Progress", 1974. PHO 0301.74.

OITICICA, Hélio. "Anotações para ANTÔNIO MANUEL”, 1974. AHO 303.73-p25.

OITICICA, Hélio. “Carta para Waly Salomão”, 23/01/1974. AHO 318.73-p20 a p37.

OITICICA, Hélio. "Branco no Branco", 1974. PHO 095.74.

OITICICA, Hélio. "Scorpionias", 1974. PHO 0148.74.

OITICICA, Hélio. "Vendo um filme de Hitchcock, 'Under Capricorn'", 1974. PHO 0318.74-15/24.

OITICICA, Hélio. "Carta para Mary e Mario Pedrosa”, 28/02/1975. AHO 1411.75.

OITICICA, Hélio. "Texto feito a pedido de Daisy Peccinini como contribuição para uma publicação sobre o objeto na arte brasileira nos ano 60". PHO 101.77.

OITICICA, Hélio. "Carta para Olympio Vasconcelos", 30/09/1978. AHO 1495.78.

OITICICA, Hélio. "O outro lado do rio", 1978. AHO 0092.78.

OITICICA, Hélio. "Anotações sobre o Ready-constructible", 1978. AHO 088.78.

OITICICA, Hélio. "Anotações Conta-Gota (para livro de Antônio Manuel sobre o corpo e implicações na arte, etc.”, 1978. AHO 0091.78-p14 a p20 e p23 a p24.

OITICICA, Hélio. "O q Faço é MÚSICA", 1979. AHO 057.79.

OITICICA, Hélio. "Memorando Caju”, 1979. AHO e PHO 114.79. 
OITICICA, Hélio. "Para press-release do MÉRIDIEN", 1979, AHO 1752.79.

OITICICA, Hélio. "Devolver a terra à Terra", 1980. AHO 123.78-p13.

\section{Textos de Hélio Oiticica consultados em publicações}

OITICICA, Hélio. "Parangolé: da antiarte às apropriações ambientais de Oiticica". GAM, n. 6, Rio de Janeiro, maio 1967.

OITICICA, Hélio. Entrevista a Walmir Ayala. (1968) AYALA, Walmir (org). A Criação Plástica em questão. Petrópolis: Vozes, 1970, p.163-6.

OITICICA, Hélio. "Hélio Oiticica retrospective at the Whitechapel Gallery, until April 6: Oiticica talks to Guy Brett". Studio International, Março/1969, v. 177 no. 909, p. 134.

OITICICA, Hélio. "On the discovery of creleisure", Art and artists, Londres, Abril/1969.v. 4 no.1.

OITICICA, Hélio. Catálogo da exposição Whitechapel Experience, Londres, Whitechapel Gallery, 1969.

OITICICA, Hélio. "Brasil Diarréia" (1970). GULLAR, Ferreira (org.) Arte brasileira hoje: situação e perspectivas . Rio de Janeiro: Paz e Terra, 1973.

CLARK, Lygia e OITICICA, Hélio. Lygia Clark - Hélio Oiticica: Cartas, 1964-74. Luciano Figueiredo (org.). Rio de Janeiro: UFRJ, 1998.

OITICICA, Hélio. Entrevista a Gardênia GARCIA, "O Artista da Terceira Margem". Arte Hoje, ano 2, no. 16, Rio de Janeiro, outubro de 1978.

OITICICA, Hélio. Entrevista a Cleusa MARIA, "Hélio Oiticica está de volta". Jornal do Brasil, 08/03/1978.

OITICICA, Hélio. Entrevista a Jary CARDOSO, “Um Mito Vadio”. Folhetim, 5/11/1978.

OITICICA, Hélio. Entrevista a Jorge GUINLE FILHO, "A última entrevista de Hélio Oiticica", Interview, abril/1980.

OITICICA, Hélio. "O q Faço é MÚSICA", catálogo da exposição "O q Faço é MÚSICA”, Galeria S. Paulo, 1986.

OITICICA, Hélio. Aspiro ao Grande Labirinto, Luciano Figueiredo; Lygia Pape; Waly Salomão (orgs.), Rio de Janeiro: Rocco, 1986. 
OITICICA, Hélio. Entrevista a Ivan CARDOSO (1979). LUCCHETTI, R. F. Ivampirismo : o cinema em pânico. Rio de Janeiro: Editora Brasil-América, Fundação do Cinema Brasileiro, 1990.

OITICICA, Hélio. "To Return Earth unto the Earth". Witte de With Cahiers \#2, ed. Richard Verlag. Roterdam: Witte de With Center for Contemporary Art, 1994.

OITICICA, Hélio. Carta para Augusto de Campos, 16/10/1971. Fios Soltos: A Arte de Hélio Oiticica. BRAGA, Paula (org.). São Paulo: Perspectiva, 2007 (no prelo).

\section{Textos sobre Hélio Oiticica}

AGUILAR, Gonzalo. "Hélio Oiticica, Haroldo y Augusto de Campos: el diálogo velado La aspiración a lo blanco" (ainda não publicado).

AGUILAR, Gonzalo. "Na Selva Branca: o Diálogo velado entre Hélio Oiticica e Augusto e Haroldo de Campos". Fios Soltos: A Arte de Hélio Oiticica. BRAGA, Paula (org.). São Paulo: Perspectiva, 2007 (no prelo).

ASBURY, Michael. "O Hélio não tinha Ginga". Fios Soltos: A Arte de Hélio Oiticica, BRAGA, Paula (org.). São Paulo: Perspectiva, 2007 (no prelo).

BRAGA, Paula. "Hélio Oiticica: Nietzsche's Übermensch in the Brazilian Slums". Tese de mestrado, University of Illinois at Urbana-Champaign, 2001.

BRAGA, Paula. "Hélio Oiticica and the Parangolés: (Ad)Dressing Nietzsche's Übermensch". Third Text, vol 17, n. 1, 2003, pp. 43-52.

BRETT, Guy. "A Paradox of Containment" in Witte de With Cahiers \#2, ed. Richard Verlag. Roterdam: Witte de With Center for Contemporary Art, 1994.

CAMPOS, Haroldo de. "Parangol(h)elium". LUCCHETTI, R. F. Ivampirismo : o cinema em pânico. Rio de Janeiro: Editora Brasil-América, Fundação do Cinema Brasileiro, 1990.

CAMPOS, Haroldo de, "O Músico da Matéria", Folha de S. Paulo, caderno Ilustrada, 16/02/1992.

CAMPOS, Haroldo de. "Asa Delta para o Êxtase". Hélio Oiticica. Catálogo da exposição itinerante 1992-1997. Roterdã: Witte de With Center for Contemporary Art; Paris: Galerie Nationale du Jeu de Paume; Barcelona: Fundació Antoni Tàpies; Lisboa: Centro de Arte Moderna da Fundação Calouste Gulbenkian; Minneapolis: Walker Art Center; Rio de Janeiro: Centro de Arte Hélio Oiticica. 
CARNEIRO, Beatriz Scigliano. Relâmpagos com Claror: Lygia Clark e Hélio Oiticica, vida como arte. S. Paulo: Imaginário, 2004.

Cosmococa Program in Progress. Cat. Exp. Projeto Hélio Oiticica, Fundación Eduardo F. Constantini, Centro de Arte Contemporânea Inhotim, 2005.

FAVARETTO, Celso. A Invenção de Hélio Oiticica. (1992) 2a. ed.. São Paulo: Editora de Universidade de São Paulo, 2000.

FAVARETTO, Celso "Inconformismo social, inconformismo estético, Hélio Oiticica". Fios Soltos: a arte de Hélio Oiticica. BRAGA, Paula (org.) São Paulo: Perspectiva, 2007 (no prelo).

FAVARETTO, Celso. "Por que Oiticica" in Por que Duchamp. BOUSSO, Daniela (org.). São Paulo : Paço das Artes / Itaú Cultural, 1999.

FAVARETTO, Celso. “A Música nos Labirintos de Hélio Oiticica”. Revista da USP, S. Paulo dez/jan/fev 1990, pp. 45-54.

FERREIRA, Glória. Hélio Oiticica e a Cena Americana. Rio de Janeiro: Centro de Arte Hélio Oiticica, 1998.

Fios Soltos: A Arte de Hélio Oiticica, BRAGA, Paula (org.). São Paulo: Perspectiva, 2007 (no prelo).

Hélio Oiticica. Catálogo da exposição itinerante 1992-1997. Roterdã: Witte de With Center for Contemporary Art; Paris: Galerie Nationale du Jeu de Paume; Barcelona: Fundació Antoni Tàpies; Lisboa: Centro de Arte Moderna da Fundação Calouste Gulbenkian; Minneapolis: Walker Art Center; Rio de Janeiro: Centro de Arte Hélio Oiticica.

Hélio Oiticica: Quasi-Cinemas. Carlos BASUALDO (org). Kölnischer Kunstverein, New Museum of Contemporary Art, Wexner Center for the Arts, The Ohio State University, 2001.

HERKENHOFF, Paulo. “Arte e Crime” em Cosmococa Programa in progress. Cat. Exp. Projeto Hélio Oiticica, Fundación Eduardo F. Constantini, Centro de Arte Contemporânea Inhotim, 2005.

JACQUES, Paola Berenstein. Estética da Ginga: a arquitetura das favelas através da obra de Hélio Oiticica. Rio de Janeiro: Casa da Palavra, 2001. 
JACQUES, Paola Berenstein. "Parangolés de Oiticica/ Favelas de Kawamata". Fios Soltos: A Arte de Hélio Oiticica, BRAGA, Paula (org.). São Paulo: Perspectiva, 2007 (no prelo).

LAGNADO, Zizette Dwek. O Mapa do Programa Ambiental. Tese de doutorado, Faculdade de Filosofia, Ciências e Letras da Universidade de São Paulo, 2003.

MORAES, Frederico. “A Poesia Abrigada”, Diário de Notícias, 05/10/1967.

MORTIMER, W. Golden, History of Coca: the divine plant of the Incas. Honolulu: University Press of the Pacific, 2000.

RUBIN, Nani. "Hélio Oiticica 'fora de série'”, O Globo, Segundo Caderno, 11/08/2001.

SALOMÃO, Waly. Hélio Oiticica: Qual é o Parangolé. Rio de Janeiro: Relume Dumará, 1996.

Tropicalia: a revolution in Brazilian Culture. BASUALDO, Carlos (ed.) São Paulo: Cosac\&Naif, 2005.

VAZ, Suzana. "HO|ME - Hélio Oiticica e Mircea Eliade; tendência para o concreto: mitologia radical de padrão iniciático". Fios Soltos: A Arte de Hélio Oiticica, BRAGA, Paula (org.). São Paulo: Perspectiva, 2007 (no prelo).

\section{Filmes e Áudios consultados}

OITICICA, Hélio. Entrevista a Ivan Cardoso, 1979.

OITICICA, Hélio e CAMPOS, Haroldo de, 1971. Heliotape. OITICICA Fo, César (org.). Rio de Janeiro: Projeto HO. Transcrição em PHO 396.71.

OITICICA, Hélio e VERGARA, Carlos, 1973. Heliotape. OITICICA Fo, César (org.). Rio de Janeiro: Projeto HO. Transcrição em PHO 0504.73.

OITICICA, Hélio. Heliotape. OITICICA Fo, César (org.). Rio de Janeiro: Projeto HO. Transcrição em PHO 0503.74.

BONISSON, Marcos. Héliophonia,, 2002. Direção: Marcos BONISSON; Edição: Joana BREA; Produção: César OITICICA FILHO. 17 min.

HITCHCOCK, Alfred. Under Capricorn, 1949. Transatlantic Pictures Corp. 117min.

CARDOSO, Ivan. HO, 1979. 13 min. 


\section{Outras obras consultadas}

AMARAL, Aracy. Arte e Meio Artístico; entre a feijoada e o X-burger. S. Paulo: Nobel, 1983.

ANDRE, Carl. "An opera for three voices". Studio International, vol. 177 n. 910 (Abril/1969), p. 176-9.

Art in Theory 1900-1990: an Anthology of Critical Ideas. HARRISON, Charles and WOOD, Paul (eds.). Oxford: Blackwell Publishers, 1992.

ARTAUD, Antonin. "O Teatro e a Peste". O Teatro e seu Duplo. Teixeira Coelho (trad.). São Paulo: Martins Fontes, 1999.

ARTAUD, Antonin. "O teatro Alfred Jarry" em . Linguagem e vida. São Paulo: Perspectiva, 1995.

BERGSON, Henri. A Evolução Criadora. Bento Prado Neto (trad.). São Paulo: Martins Fontes, 2005.

BERGSON, Henri . Matéria e Memória: ensaio sobre a relação do corpo com o espírito. Paulo Neves (trad.). S. Paulo: Martins Fontes, 1990.

BRETT, Guy. Brasil Experimental; arte/vida: proposições e paradoxos, MACIEL, Katia (org.). Rio de Janeiro: Contra-Capa, 2005.

BROOKES, Fred. “Schwitters' Merzbarn”. Studio International. v. 177 no. 911 (Maio, 1969), p.224-7.

BUREN, Daniel. "Beware!”, Studio International, vol. 179, n. 920 (Março, 1970), p. 100-104.

BURGIN, Victor. "Situational Aesthetics". Studio International. vol. 178 n. 915 (Outubro, 1969), p. 118-21.

BURROUGHS, William. Almoço Nú, S. Paulo: Ediouro, 2005.

CAGE, John. Silence. New England: Wesleyan University Press, 1973.

CAMPOS, Augusto de e CAMPOS, Haroldo de. ReVisão Sousândrade. Rio de Janerio: Nova Fronteira, 1982.

CAMPOS, Haroldo de. Hagoromo de Zeami: o charme sutil. São Paulo: Estação Liberdade, 1993. 
CERTEAU, Michel de. A invenção do Cotidiano: Artes de Fazer. Petrópolis: Vozes, 1999.

CLAURA, Michel, “Conceptual Misconceptions". Studio international. v.179 n. 918 (Janeiro, 1970), p. 5-6.

COELHO, Teixeira, "Arte e Cultura da Arte", texto apresentado no simpósio "Padrões aos Pedaços: o pensamento contemporâneo na arte". Paço das Artes, S. Paulo, agosto de 2005.

Conceptual Art: a critical Anthology ALBERRO, Alberto and STIMSON, Blake (eds.). Cambridge: MIT Press, 1999.

CORREA José Celso Martinez. Primeiro Ato. São Paulo: Editora34, 1998.

DEBORD, Guy. A Sociedade do Espetáculo. Rio de Janeiro: Contraponto, 1997.

DELEUZE, Gilles. Nietzsche and Philosophy. New York: Columbia University Press, 2002.

DELEUZE, Gilles. Nietzsche e a Filosofia. Porto: Rés-Editora, 2001.

DELEUZE "Pensamento Nômade" in MARTON, Scarlett (org.) . Nietzsche hoje? Colóquio de Cerisy. São Paulo: Brasiliense, 1985.

Escritos de artistas: anos 60/70. FERREIRA, Glória e COTRIM, Cecília (orgs.). Rio de Janeiro: Jorge Zahar, 2006.

ELIADE, Mircea. O Sagrado e o Profano: a essência das religiões. São Paulo: Martins Fontes, 2001.

FAVARETTO, Celso. Tropicália, alegoria, alegria. Cotia: Ateliê Editorial, 3a edição, 2000.

FAVARETTO, Celso. "Tropicália: the explosion of the obvious" in Tropicalia: a revolution in Brazilian Culture. BASUALDO, Carlos (ed.) São Paulo: Cosac\&Naif, 2005.

FAVARETTO, Celso."60/70 : Viver a Arte, inventar a Vida" Seminário "Vida Coletiva," XXVII Bienal de S. Paulo, 2006.

FINEBERG, Jonathan. Art after the 1940s: Strategies of Being. $2^{\text {nd }}$ ed. New Jersey: Prentice Hall, 2000. 
FOUCAULT, Michel. "Nietzsche, a Genealogia, a História" (1971) in Arqueologia das Ciências e história dos sistemas de Pensamento (Ditos e Escritos II). MOTTA, Manuel Barros da (org.) Rio de Janeiro: Forense Universitária, 2000.

FRAMPTON, Kenneth. Modern Architecture: a critical history. New York: Thames and Hudson, 1992.

FREUD, Sigmund, The Cocaine Papers. DONOGHUE, A. K. e HILLMAN, J. (org), Viena e Zurique, Dunquin Press, 1963.

FREUD, Sigmund. Cocaine Papers; By Sigmund Freud. BYCK, Robert (ed.). New York: Stonehill Publishing Co., 1974.

FREUD, Sigmund. Freud e a Cocaína. BYCK, Robert (ed.). Rio de Janeiro: Espaço e Tempo, 1989.

GALARD, Jean. A Beleza do Gesto. São Paulo: EDUSP, 1997.

GILBERT and GEORGE. “A Magazine Sculpture”. Studio International, v. 179 n. 922 (Maio/1970), p.218-21.

GRLIC, Danto. "Nietzsche e o eterno retorno do mesmo ou o retorno da essência artística na arte" in MARTON, Scarlet (org.). Nietzsche hoje? Colóquio de Cerisy. São Paulo: Brasiliense, 1985.

GEYERHAHN, Suzana. “A Arte dos Mestres”. Malasartes, n. 2 (dezembro de 1975 a fevereiro de 1976), p. 20-1.

HOFFMAN, Abbie. Woodstock Nation, New York: Random House, 1969.

JACQUES, Paola Berenstein. "Elogio aos Errantes: a arte de se perder na cidade". Corpos e Cenários Urbanos. JEUDY, Henri e JACQUES, Paola Berenstein (orgs.) Salvador: EDUFBA, 2006.

KANDINSKY, Wassily. Do Espiritual na Arte. S. Paulo: Martins Fontes, 1996.

KAPOOR, Anish , Ascension. Cat. Exp. Centro Cultural Banco do Brasil, 2006.

KOSSOVITCH, Leon. Signos e Poderes em Nietzsche. (1979). 2a ed. Rio de Janeiro: Azougue Editorial, 2004.

KOSUTH, Joseph. "Art after Philosophy”. Studio International. Primeira parte (v. 178 n. 915, outubro 1969, p. 134-7); segunda parte (v. 178 n. 916, novembro 1969, p. 160-1); terceira parte (v. 178 n. 917, dezembro 1969, p. 212-13) . 
KOSUTH, Josef. “Arte depois da Filosofia”. Malasartes, n. 1, 1975, p.10-3.

LAGNADO, Lisette. "Ateliê, Laboratório e Canteiro de Obras" in Folha de S. Paulo, Caderno Mais!, 13/01/2002.

LEWITT, Sol. "Drawing Series 1968 (Fours)". Studio International, vol. 177 n. 910 (Abril 1969), p. 189.

LEWITT, Sol. "Parágrafos sobre Arte Conceitual". Escritos de Artistas: anos 60/70. FERREIRA, Glória e COTRIM, Cecília (orgs.). Rio de Janeiro: Jorge Zahar, 2006.

LEWITT, Sol. "Paragraphs on Conceptual Art”. Artforum. vol. 5, n. 10, 1967, p. 79-83.

LIPPARD, Lucy, “Groups”. Studio International, v. 179, n. 920 (Março, 1970), p.93-9.

LONG, Richard. "Nineteen Stills from the work of Richard Long”. Studio International. vol. 179, n. 920 (March, 1970), p. 106-111.

MALEVITCH, K. S. "On new systems in art” in___Essays on Art: 1915 - 1933 vol. 1. Xenia Glowacki-Prus e Arnold McMillin (trad.), ANDERSEN, Troels (ed.). (London; Chester Springs, Pa. : Rapp \& Whiting: Dufour Editions, 1969.

MALEVITCH, K.S.. "Suprematism". Theories of Modern Art, CHIPP, H.B. (ed.). Berkeley, Los Angeles and London: University of California Press, 1984.

MARCUSE, Herbert. Eros e Civilização: uma interpretação filosófica do pensamento de Freud. Rio de Janeiro, LTC, 1999.

MARTINS, Carlos Estevam. "Anteprojeto do Manifesto do CPC". Arte em Revista ano 1, no.1, 1979.

MARTINS, Carlos Estevam. "História do CPC". Arte em Revista ano 2, no.3 , 1980.

MARTON, Scarlett. “A Terceira Margem da Interpretação”. MÜLLER-LAUTER, $A$ Doutrina da Vontade de Poder em Nietzsche. S. Paulo: Annablume, 1997.

MARTON, Scarlett. "Eterno Retorno do Mesmo: tese cosmológica ou imperativo ético?" in Editorial, 2000. . Extravagâncias: Ensaios sobre a filosofia de Nietzsche. São Paulo: Discurso

MCLUHAN, Marshall. Os meios de comunicação como extensões do homem (understanding media). Décio Pignatari (trad.). São Paulo: Cultrix, 1974. 
MCSHINE, Kynaston, Information, Nova Iorque: MOMA, 1970.

MERLEAU-PONTY, Maurice. Fenomenologia da Percepção. Carlos Alberto Ribeiro de Moura (trad.). São Paulo: Martin Fontes, 2006.

MOTTA, Nelson. Memória Musical. Porto Alegre: Sulina, 1990.

MÜLLER-LAUTER, A Doutrina da Vontade de Poder em Nietzsche. S. Paulo: Annablume, 1997.

NIETZSCHE, Friedrich. The Will to Power. KAUFMANN, Walter (ed.). New York, Vintage Books, 1968.

NIETZSCHE, Friedrich. Obras incompletas. Gerard LEBRUN (org.), Rubens Rodrigues Torres Filho (trad.). $3^{\text {a }}$ edição. São Paulo: Abril Cultural, 1983.

NIETZSCHE, Friedrich. The Portable Nietzsche (ed.) Walter Kaufmann. New York: Penguin Books, 1976.

NIETZSCHE, Friedrich. Genealogia da Moral; uma polêmica. Paulo César de Souza (trad.).São Paulo: Companhia das Letras, 1998.

NIETZSCHE, Friedrich. Aurora: reflexões sobre os preconceitos morais. Paulo César de Souza (trad.). São Paulo: Companhia das Letras, 2004.

NIETZSCHE, Friedrich. The Birth of Tragedy and The Case of Wagner, ed. Walter Kaufmann. New York: Vintage Books, 1967.

NIETZSCHE, Friedrich. On the Advantage and Disadvantage of History for Life. Indianapolis: Hackett Publishing, 1980.

PEREIRA, Carlos Alberto e BUARQUE DE HOLLANDA, Heloisa. Patrulhas Ideológicas. Sao Paulo : Brasiliense, 1980.

PIGNATARI, Décio. "Marco Zero de Andrade" em O Estado de São Paulo, Suplemento Literário 24/10/1964.

POUND, Ezra. $A B C$ da Literatura. Augusto de Campos e José Paulo Paes (trad.). São Paulo: Cultrix, 1970.

Projeto Construtivo Brasileiro na Arte: 1950-1962. AMARAL, Aracy (org.) Rio de Janeiro, Museu de Arte Moderna; São Paulo: Pinacoteca do Estado, 1977. 
RORIMER, Anne. "Siting the page: Exhibiting Works in Publications - Some Examples of Conceptual Art in the USA" in Rewriting Conceptual Art. NEWMAN, Michael and BIRD, Jon (eds.). Londres: Reaktion Books, 1999, p. 11-26.

SARTRE, Jean-Paul. Saint Genet: ator e mártir. Petrópolis: Vozes, 2002.

SCHÖPKE, Regina. Por uma Filosofia da Diferença: Deleuze, Pensador Nômade, Edusp, 2004.

SMITHSON, Robert. Robert Smithson: The Collected Writings. FLAM, Jack (ed.). University of California Press: Berkley and Los Angeles, 1996.

SMITHSON, Robert. “Aerial Art”. Studio International, vol. 177 no. 910 , (Abril/1969), p.180-1.

SMITHSON, Robert. The writings of Robert Smithson. HOLT, Nancy (ed.). New York: New York University Press, 1979.

Six years: the dematerialization of the art object from 1966 to 1972 . LIPPARD, Lucy (ed.) Londres: Studio Vista, 1973.

TEIXEIRA, Ana. Trocas: A Arte na Rua e a Rua na Arte, dissertação de mestrado, Escola de Comunicações e Artes da Universidade de S. Paulo, 2005.

TUNGA, Tunga - Barroco de Lírios. São Paulo: Cosac\&Naif, 1997.

VENTURA, Zuenir. 1968: o ano que não terminou. Rio de Janeiro : Nova Fronteira, 1989.

WINNICOTT, Donald W. O Brincar e a Realidade. Rio de Janeiro: Imago Editora, 1975.

ZILIO, Carlos. "Da Antropofagia à Tropicália". NOVAES, Adauto (org.) O Nacional e o Popular na Cultura Brasileira. São Paulo: Brasiliense, 1982.

ZOURABICHVILI, François. O Vocabulário de Deleuze. Rio de Janeiro: RelumeDumará, 2004. 